\title{
Trends in Streamflow of the San Pedro River,
}

Southeastern Arizona, and Regional Trends in Precipitation and Streamflow in Southeastern Arizona and Southwestern New Mexico

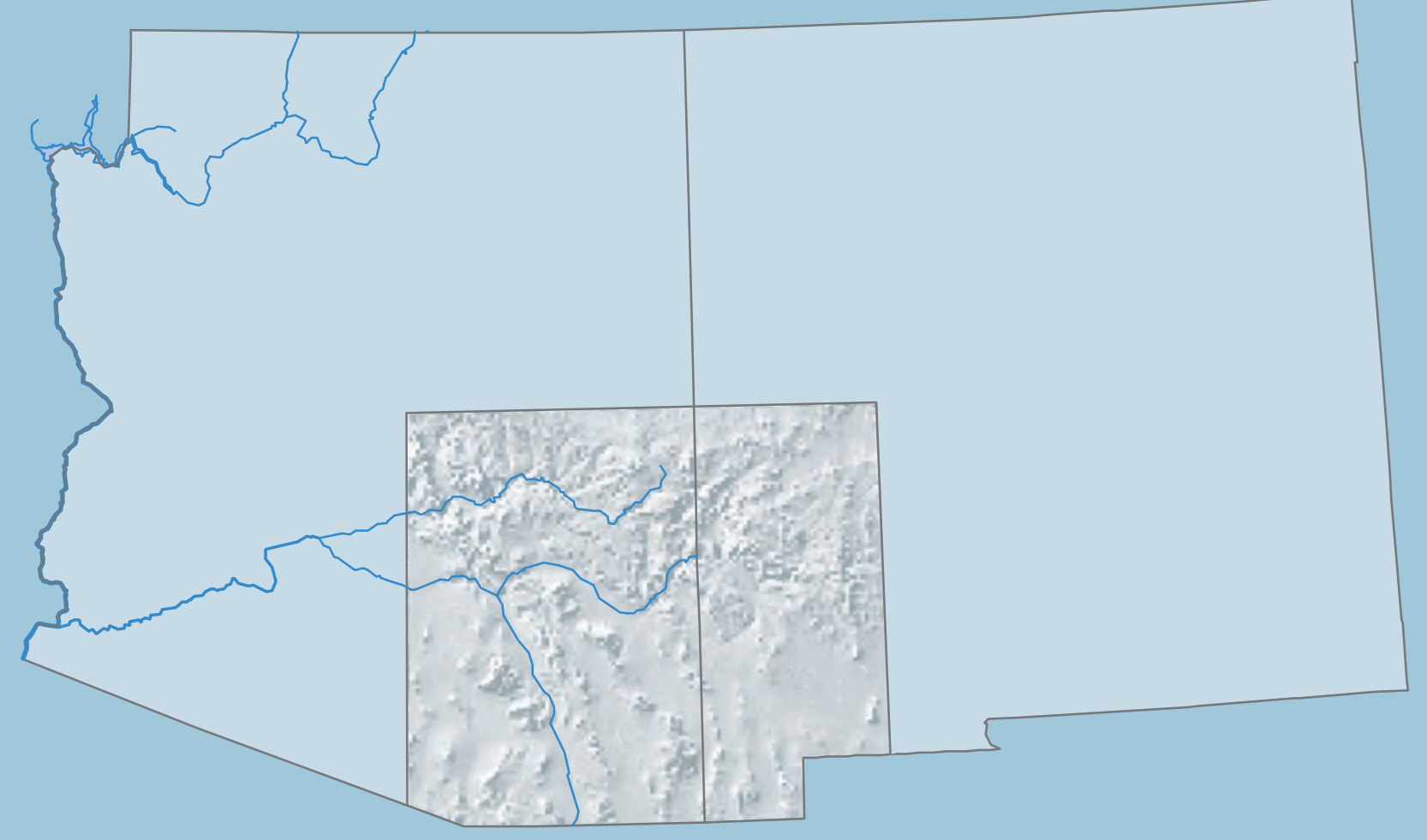

Professional Paper 1712

\section{\#USGS




\section{Inside Front Cover}

\section{Blank}




\section{Trends in Streamflow of the San Pedro River, Southeastern Arizona, and Regional Trends in Precipitation and Streamflow in Southeastern Arizona and Southwestern New Mexico}

By Blakemore E. Thomas and Don R. Pool

Professional Paper 1712 


\section{U.S. Department of the Interior \\ P. Lynn Scarlett, Acting Secretary}

\section{U.S. Geological Survey \\ P. Patrick Leahy, Acting Director}

\section{U.S. Geological Survey, Reston, Virginia: 2006}

For product and ordering information:

World Wide Web: http://www.usgs.gov/pubprod

Telephone: 1-888-ASK-USGS

For more information on the USGS--the Federal source for science about the Earth, its natural and living resources, natural hazards, and the environment:

World Wide Web: http://www.usgs.gov

Telephone: 1-888-ASK-USGS

Any use of trade, product, or firm names is for descriptive purposes only and does not imply endorsement by the U.S. Government.

Although this report is in the public domain, permission must be secured from the individual copyright owners to reproduce any copyrighted materials contained within this report.

Suggested citation:

Thomas, B.E., Pool, D.R., 2006, Trends in Streamflow of the San Pedro River, Southeastern Arizona, and Regional Trends in Precipitation and Streamflow in Southeastern Arizona and Southwestern New Mexico: U.S. Geological Survey Professional Paper 1712, $79 p$.

\section{Library of Congress Cataloging-in-Publication Data}

Thomas, Blakemore E.

Trends in streamflow of the San Pedro River, Southeastern Arizona, and regional trends in precipitation and streamflow in Southeastern Arizona and Southwestern New Mexico / by Blakemore E. Thomas and Don R. Pool. p. cm. -(U.S. Geological Survey professional paper ; 1712) Includes bibliographic references.

1. Streamflow-Arizona. 2. Streamflow-San Pedro River (New Mexico and Arizona). 3. Rain and rainfall-Arizona 4. Rain and rainfall-San Pedro River Watershed (New Mexico and Ariz.) I. Pool, D.R. II. Geological Survey (U.S.) III. Trends in streamflow of the San Pedro River, Southeastern Arizona, and regional trends in precipitation and streamflow in Southeastern Arizona and Southwestern New Mexico. IV. Series: U.S. Geological Survey professional paper; 1712.

GB1225.A6T56 2005

$551.48^{\prime} 309791-\mathrm{dc} 22$ 


\section{Contents}

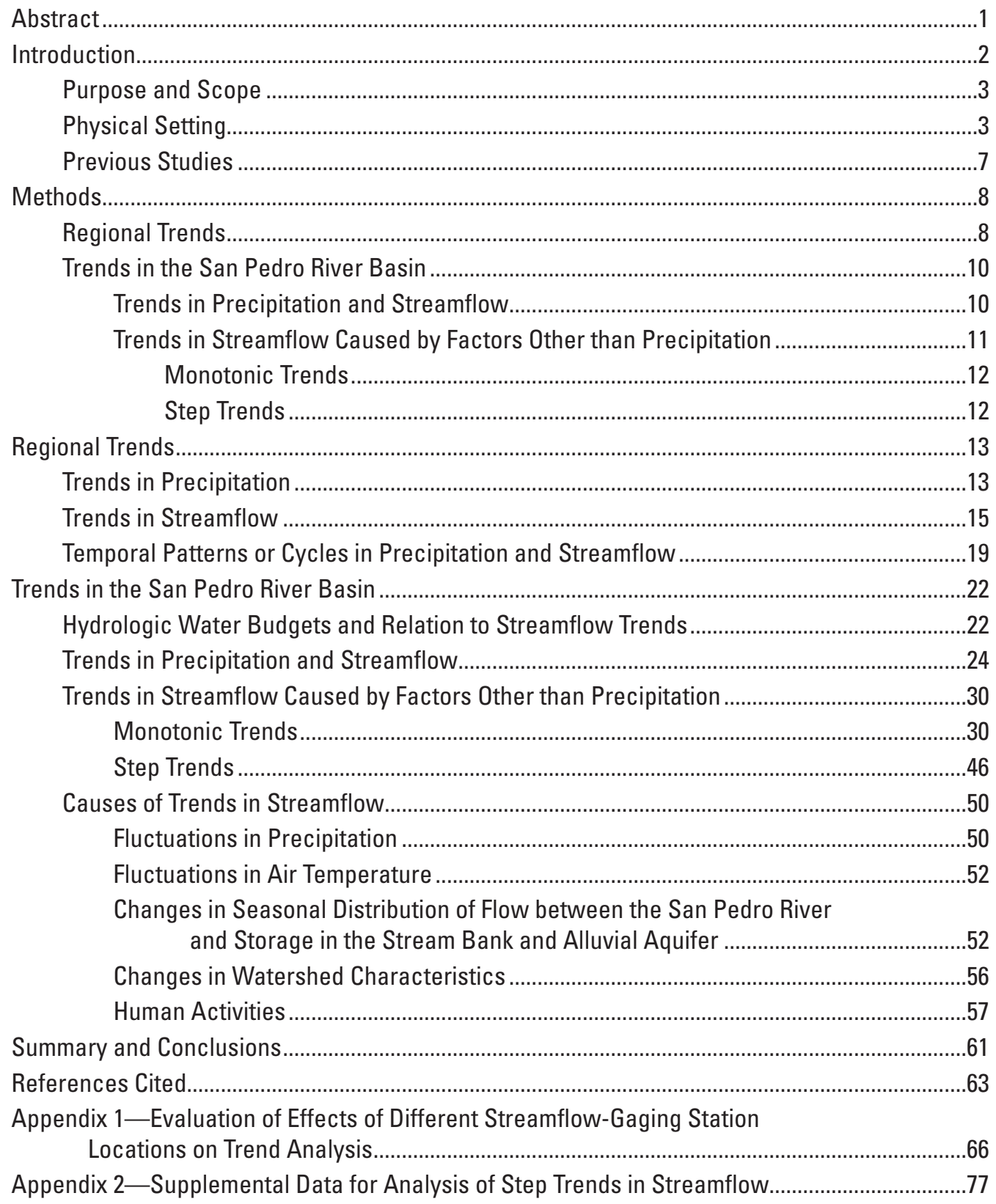




\section{Figures}

1. Graphs showing trends in annual and seasonal streamflow of the San Pedro

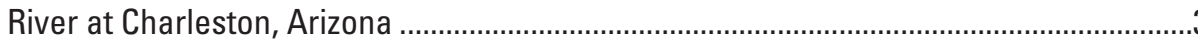

2. Map showing location of regional study area and data-collection sites .........................4

3. Map showing location of the Upper San Pedro River Basin and Charleston watershed, southeastern Arizona and northern Sonora, Mexico ......................................5

4. Maps showing ratios of summer to annual value. A, Precipitation; B, Streamflow...........6

5. Graphs showing: A, Average monthly total precipitation at Tombstone, Arizona, and $B$, Historical distribution of daily streamflows for the San PedroRiver at Charleston, Arizona

6. Maps showing regional trends in precipitation, 1950-2002. A, Winter; B, Summer; C, Annual

7. Maps showing regional trends in streamflow, 1950-2002. A, Winter;

B, Summer; C, Annual

8-22. Graphs showing:

8. Trends in regional normalized seasonal precipitation, southeastern Arizona and southwestern New Mexico

9. Trends in normalized seasonal streamflow for the San Pedro River at Charleston, Arizona, and regional normalized streamflow for the northwest and northeast parts of the study area, southeastern Arizona and southwestern New Mexico

10. Trends in annual and seasonal precipitation at Tombstone, Arizona...

11. Step trends in central tendency and variability of precipitation at Tombstone, Arizona, and streamflow of the San Pedro River at Charleston, Arizona.

12. LOWESS fits between precipitation at Tombstone, Arizona, and selected monthly total streamflows of the San Pedro River at Charleston, Arizona

13. Trends in monthly total streamflow and monthly total streamflow adjusted for variation in precipitation, January-December, San Pedro River at Charleston, Arizona

14. Trends in monthly low flow and monthly low flow adjusted for variation in precipitation, January-December, San Pedro River at Charleston, Arizona

15. Trends in maximum daily storm runoff and maximum daily storm runoff adjusted for variation in precipitation, selected months, San Pedro River at Charleston, Arizona

16. Regression relations between precipitation at Tombstone, Arizona, and monthly total streamflow for February through December for three time periods, San Pedro River at Charleston, Arizona .

17. Regression relations between precipitation at Tombstone, Arizona, and maximum daily storm runoff for July through September for three time periods, San Pedro River at Charleston, Arizona..

18. Annual average temperature at Tombstone, Arizona, 1913-2002 …...............................52

19. Correlations between monthly total streamflows and total streamflows for 24 previous months, San Pedro River at Charleston, Arizona, 1913-2002

20. Correlations between monthly low flows and total streamflows for 24 previous months, San Pedro River at Charleston, Arizona, 1931-2002.

21. Correlations between monthly precipitation and precipitation for 24 previous months, Tombstone, Arizona, 1913-2002..

22. Ground-water pumpage in the Upper San Pedro River Basin, Sierra Vista subwatershed, Arizona and Sonora, Mexico, 1940-2002 


\section{Tables}

1. Data-collection sites for analysis of regional trends in precipitation, southeastern Arizona and southwestern New Mexico

2. Data-collection sites for analysis of regional trends in streamflow, southeastern Arizona and southwestern New Mexico

3. Regional trends in precipitation for 11 time periods, 1930-2002, southeastern Arizona and southwestern New Mexico

4. Trends in seasonal and annual total streamflow at 6 gaging stations for 11 time periods, 1930-2002, southeastern Arizona and southwestern New Mexico

5. Trends in seasonal and annual total streamflow at 21 gaging stations for periods of record, southeastern Arizona and southwestern New Mexico

6. Predevelopment water budget for the watershed of the San Pedro River at Charleston, Arizona.

7. Predevelopment water budget for ground-water system in the watershed of the San Pedro River at Charleston, Arizona

8. Water budget for seasonal streamflow of the San Pedro River at Charleston, Arizona .

9. Trends in monthly, seasonal, and annual precipitation at Tombstone, Arizona, 1913-2002

10. Trends in monthly, seasonal, and annual total precipitation at Tombstone, Arizona, for selected time periods.

11. Changes in seasonal and annual total streamflow and low flow from the predevelopment period to 1991-2002, San Pedro River at Charleston, Arizona .

12. Trends in seasonal total streamflow of the San Pedro River at Palominas, Charleston, and Redington, Arizona, for selected time periods

13. Seasonal relations between low flow, total flow, and maximum daily storm runoff, San Pedro River at Charleston, Arizona, 1931-2002.

14. Results of LOWESS regression analyses between monthly precipitation at Tombstone, Arizona, and monthly total streamflow for the San Pedro River at Charleston, Arizona; and between precipitation at Tombstone and time, 1913-2002.

15. Explanatory variables for LOWESS regression equations between monthly precipitation at Tombstone, Arizona, and monthly streamflow for the San Pedro River at Charleston, Arizona

16. Results of LOWESS regression analyses between monthly precipitation at Tombstone, Arizona, and monthly low flow for the San Pedro River at Charleston, Arizona, and between precipitation at Tombstone and time, 1931-2002

17. Results of LOWESS regression analyses between precipitation at Tombstone, Arizona, and maximum daily storm runoff for the San Pedro River at Charleston, Arizona; and between precipitation at Tombstone and time, 1913-2002, for selected months.

18. Trends in monthly total streamflow and monthly total streamflow adjusted for variation in precipitation, San Pedro River at Charleston, Arizona, 1913-2002 


\section{Tables-Continued}

19. Trends in monthly low flow and monthly low flow adjusted for variation in precipitation, San Pedro River at Charleston, Arizona, 1931-2002

20. Trends in maximum daily storm runoff and maximum daily storm runoff adjusted for variation in precipitation, by month, San Pedro River at Charleston, Arizona, 1913-2002.

21. Results of significance tests for differences among regression relations between precipitation at Tombstone, Arizona, and monthly total streamflow for the San Pedro River at Charleston, Arizona, for three time periods

22. Results of significance tests for differences among regression relations between precipitation at Tombstone, Arizona, and maximum daily storm runoff for the San Pedro River at Charleston, Arizona, for July, August, and September, for three time periods

24. Changes from 1913 to 2002 in monthly average precipitation at Tombstone, Arizona, and monthly average streamflow for San Pedro River at Charleston, Arizona

23. Factors that could cause trends in seasonal streamflow of the San Pedro River at Charleston, Arizona

25. Changes in estimated annual base flow for San Pedro River from predevelopment period to 1977-2002, previous studies, and this study

1A. Results of LOWESS regression analyses between precipitation at Tombstone, Arizona, and monthly total streamflow for the San Pedro River at Charleston, Arizona, and between precipitation at Tombstone and time, 1943-2002

1B. Results of LOWESS regression analyses between precipitation at Tombstone, Arizona, and monthly low flow for the San Pedro River at Charleston, Arizona, and between precipitation at Tombstone and time, 1943-2002.

1C. Results of LOWESS regression analyses between precipitation at Tombstone, Arizona, and maximum daily storm runoff for the San Pedro River at Charleston, Arizona, and between precipitation at Tombstone and time, 1943-2002, for selected months

1D. Trends in monthly total streamflow and monthly total streamflow adjusted for variation in precipitation, San Pedro River at Charleston, Arizona, 1943-2002.

1E. Trends in monthly low flow and monthly low flow adjusted for variation in precipitation, San Pedro River at Charleston, Arizona, 1943-2002.

1F. Trends in maximum daily storm runoff and maximum daily storm runoff adjusted for variation in precipitation, by month, San Pedro River at Charleston, Arizona, 1943-2002

1G. Results of LOWESS regression analyses between precipitation at Tombstone, Arizona, and station-adjusted monthly total streamflow for the San Pedro River at Charleston, Arizona, and between precipitation at Tombstone and time, 1913-2002

1H. Results of LOWESS regression analyses between precipitation at Tombstone, Arizona, and station-adjusted maximum daily storm runoff for the San Pedro River at Charleston, Arizona, and between precipitation at Tombstone and time, 1913-2002, for selected months 


\section{Tables-Continued}

11. Trends in station-adjusted monthly total streamflow and station-adjusted monthly total streamflow adjusted for variation in precipitation, San Pedro River at Charleston, Arizona, 1913-2002.

1J. Trends in station-adjusted maximum daily storm runoff and station-adjusted maximum daily storm runoff adjusted for variation in precipitation, by month, San Pedro River at Charleston, Arizona, 1913-2002

2A. Results of least-squares regression analyses between precipitation at Tombstone, Arizona, and monthly total streamflow for the San Pedro River at Charleston, Arizona, for selected time periods.

2B. Results of least-squares regression analyses between precipitation at Tombstone, Arizona, and maximum daily storm runoff for the San Pedro River at Charleston, Arizona, for selected time periods.

\section{Conversion Factors and Datums}

\begin{tabular}{|c|c|c|}
\hline Multiply & By & To obtain \\
\hline \multicolumn{3}{|c|}{ Length } \\
\hline inch (in.) & 2.54 & centimeter $(\mathrm{cm})$ \\
\hline inch (in.) & 25.4 & millimeter $(\mathrm{mm})$ \\
\hline foot (ft) & 0.3048 & meter $(\mathrm{m})$ \\
\hline mile (mi) & 1.609 & kilometer $(\mathrm{km})$ \\
\hline \multicolumn{3}{|c|}{ Area } \\
\hline acre & 4,047 & square meter $\left(\mathrm{m}^{2}\right)$ \\
\hline acre & 0.4047 & hectare (ha) \\
\hline acre & 0.4047 & square hectometer $\left(\mathrm{hm}^{2}\right)$ \\
\hline acre & 0.004047 & square kilometer $\left(\mathrm{km}^{2}\right)$ \\
\hline square foot $\left(\mathrm{ft}^{2}\right)$ & 929.0 & square centimeter $\left(\mathrm{cm}^{2}\right)$ \\
\hline square foot $\left(\mathrm{ft}^{2}\right)$ & 0.09290 & square meter $\left(\mathrm{m}^{2}\right)$ \\
\hline square mile $\left(\mathrm{mi}^{2}\right)$ & 259.0 & hectare (ha) \\
\hline square mile $\left(\mathrm{mi}^{2}\right)$ & 2.590 & square kilometer $\left(\mathrm{km}^{2}\right)$ \\
\hline \multicolumn{3}{|c|}{ Volume } \\
\hline cubic foot $\left(\mathrm{ft}^{3}\right)$ & 28.32 & cubic decimeter $\left(\mathrm{dm}^{3}\right)$ \\
\hline cubic foot $\left(\mathrm{ft}^{3}\right)$ & 0.02832 & cubic meter $\left(\mathrm{m}^{3}\right)$ \\
\hline acre-foot (acre-ft) & 1,233 & cubic meter $\left(\mathrm{m}^{3}\right)$ \\
\hline acre-foot (acre-ft) & 0.001233 & cubic hectometer $\left(\mathrm{hm}^{3}\right)$ \\
\hline \multicolumn{3}{|c|}{ Flow rate } \\
\hline foot per second (ft/s) & 0.3048 & meter per second $(\mathrm{m} / \mathrm{s})$ \\
\hline cubic foot per second $\left(\mathrm{ft}^{3} / \mathrm{s}\right)$ & 0.02832 & cubic meter per second $\left(\mathrm{m}^{3} / \mathrm{s}\right)$ \\
\hline
\end{tabular}

Temperature in degrees Celsius $\left({ }^{\circ} \mathrm{C}\right)$ may be converted to degrees Fahrenheit $\left({ }^{\circ} \mathrm{F}\right)$ as follows:

$$
{ }^{\circ} \mathrm{F}=1.8\left({ }^{\circ} \mathrm{C}\right)+32
$$

Vertical coordinate information is referenced to the National Geodetic Vertical Datum of 1929 (NGVD 29).

Horizontal coordinate information is referenced to the North American Datum of 1927 (NAD 27).

Elevation, as used in this report, refers to the distance above or below NGVD 29. 
This page left blank intentionally. 


\title{
Trends in Streamflow of the San Pedro River, Southeastern Arizona, and Regional Trends in Precipitation and Streamflow in Southeastern Arizona and Southwestern New Mexico
}

\author{
By Blakemore E. Thomas and Don R. Pool
}

\section{Abstract}

This study was done to improve the understanding of trends in streamflow of the San Pedro River in southeastern Arizona. Annual streamflow of the river at Charleston, Arizona, has decreased by more than 50 percent during the 20th century. The San Pedro River is one of the few remaining free-flowing perennial streams in the arid Southwestern United States, and the riparian forest along the river supports several endangered species and is an important habitat for migratory birds.

Trends in seasonal and annual precipitation and streamflow were evaluated for surrounding areas in southeastern Arizona and southwestern New Mexico to provide a regional perspective for the trends of the San Pedro River. Seasonal and annual streamflow trends and the relation between precipitation and streamflow in the San Pedro River Basin were evaluated to improve the understanding of the causes of trends.

There were few significant trends in seasonal and annual precipitation or streamflow for the regional study area. Precipitation and streamflow records were analyzed for 11 time periods ranging from 1930 to 2002; no significant trends were found in 92 percent of the trend tests for precipitation, and no significant trends were found in 79 percent of the trend tests for streamflow. For the trends in precipitation that were significant, 90 percent were positive and most of those positive trends were in records of winter, spring, or annual precipitation that started during the midcentury drought in 1945-60. For the trends in streamflow that were significant, about half were positive and half were negative.

Trends in precipitation in the San Pedro River Basin were similar to regional precipitation trends for spring and fall values and were different for summer and annual values. The largest difference was in annual precipitation, for which no trend tests were significant in the San Pedro River Basin, and 23 percent of the trend tests were significantly positive in the rest of the study area. Streamflow trends for the San Pedro River were different from regional streamflow trends. All seasonal flows for the San Pedro River, except winter flows, had significant decreasing trends, and seasonal flows for most streams in the rest of the study area had either no trend or a significant increasing trend. Two streams adjacent to the San Pedro River Basin (Whitewater Draw and Santa Cruz River), however, had significant decreasing trends in summer streamflow.

Factors that caused the decreasing trends in streamflow of the San Pedro River at Charleston were investigated. Possible factors were fluctuations in precipitation and air temperature, changes in watershed characteristics, human activities, or changes in seasonal distribution of bank storage. This study statistically removed or accounted for the variation in streamflow caused by fluctuations in precipitation. Thus, the remaining variation or trend in streamflow was caused by factors other than precipitation.

Two methods were used to partition the variation in streamflow and to determine trends in the partitioned variation: (1) regression analysis between precipitation and streamflow using all years in the record and evaluation of time trends in regression residuals, and (2) development of regression equations between precipitation and streamflow for three time periods (early, middle, and late parts of the record) and testing to determine if the three regression equations were significantly different. The methods were applied to monthly values of total flow (average flow) and storm runoff (maximum daily mean flow) for 1913-2002, and to monthly values of low flow (3-day low flow) for 1931-2002.

Statistical tests provide strong evidence that factors other than precipitation caused a decrease in streamflow of the San Pedro River. Factors other than precipitation caused significant decreasing trends in streamflows for late spring through early winter and did not cause significant trends for late winter through early spring. Total flows had significant decreasing trends in June through December, low flows had significant decreasing trends in May through December, and 
storm runoff had significant decreasing trends in July through September. The effects of factors other than precipitation were tested only for July through October for storm runoff.

Besides fluctuations in precipitation, the principal factors that could have caused decreasing streamflow trends are (1) changes in watershed characteristics such as changes in riparian vegetation, changes in upland vegetation, and changes in stream-channel morphology, and (2) human activities such as ground-water pumping, construction of runoff-detention structures, urbanization, and cattle ranching (grazing).

Changes in upland and riparian vegetation likely were major factors in the decreasing trends in total streamflows and low flows. Total flows and low flows in summer and fall were significantly affected by factors other than precipitation, but late winter flows were not significantly affected. The significant effects coincide with high rates of transpiration from vegetation in the summer and the nonsignificant effects coincide with low rates of transpiration in the late winter. Another piece of evidence that implicates vegetation as a cause is that the upland and riparian vegetation of the San Pedro River Basin changed during the 20th century. The relative proportions of different species changed in upland vegetation (woody plants increased and grasses decreased), and the areal extent and density of riparian vegetation increased substantially.

Ground-water pumping in the United States and Mexico had a mixed influence on streamflow trends at Charleston, Arizona; statistical analyses indicate that seasonal pumping from wells near the river for irrigation in the spring and summer was a major factor in the decrease in low flows and that year-round pumping from wells in the regional aquifer away from the river was not a major factor in the decrease in low flows. If regional pumping had caused a trend, the pumping should have affected low flows for all months of the year, but factors other than precipitation did not cause significant trends in low flows for January, February, March, and May. Most of the local pumping near the river was during the spring and summer, and this seasonal pumping probably caused some decreases in summer low flows. These conclusions are for trends from 1913 to 2002, and regional pumping in the United States and Mexico could affect streamflow at Charleston in the future, because regional ground-water pumping often has a delayed effect on streamflows.

\section{Introduction}

Concerns about trends in precipitation and streamflow have increased in the Southwestern United States, where the population is increasing at a rapid rate and water supplies are limited because of an arid or semiarid climate (Hurd and others, 1999; Webb and others, 2004). Resource managers need to understand the characteristics and the causes of these trends. Precipitation and streamflow can have a monotonic increasing or decreasing trend, can shift from high to low values for extended periods of time, or can alternate in cycles from high to low values. Information about these trend characteristics is useful because the same characteristics might continue in the future. The cause of a streamflow trend is usually difficult to determine and quantify. Trends are commonly a result of natural fluctuations in precipitation, but trends can also result from other factors, such as human activities or changes in watershed characteristics. Resource managers need to know if precipitation fluctuations or other factors caused the trend. Land- and water-management decisions can be more effective when the cause of a trend is known.

This report presents results of a study of trends in streamflow for a river in the Southwestern United States. Total streamflow and low flow in the San Pedro River in southeastern Arizona has decreased during the past 90 years (Pool and Coes, 1999), and resource managers and the public have a great interest in learning more about the trend and more about possible causes of the trend. The San Pedro River is one of the few remaining free-flowing perennial streams in the arid Southwest. The riparian forest along the river supports several endangered species and is an important habitat for migratory birds. The decreasing trends in streamflow of the San Pedro River are causing concerns that riparian habitat may be damaged and that overall longterm water supply in the watershed may be threatened. In 1988, Congress established the San Pedro Riparian National Conservation Area (SPRNCA) to preserve and protect the riparian area. From 1994 to 2005, the U.S. Geological Survey, in cooperation with the Bureau of Land Management and Cochise County, Arizona, has conducted studies to improve the understanding of the hydrology of the Upper San Pedro River Basin. This study of streamflow trends was done during 2003-04 and was part of the larger cooperative program.

The decreases in streamflow of the San Pedro River at Charleston, Arizona have been substantial: changes in total streamflow from the first 20 years of streamflow record (1913-36) to the last 20 years of record (1983-2002) were -54 percent for annual flows, -70 percent for summer flows, and -20 percent for winter flows (fig. 1). These decreasing trends are anomalous compared to generally increasing streamflow trends during the 20th century in most of the United States (Lins and Slack, 1999).

Potential causes of the decreasing streamflow trends of the San Pedro River are (1) fluctuations in precipitation, (2) fluctuations in temperature, (3) changes in watershed characteristics, (4) human activities, and (5) changes in the seasonal distribution of bank storage. Possible watershed characteristics that may have influenced streamflow trends are changes in riparian vegetation, changes in upland vegetation, and changes in stream-channel morphology. Possible human activities that may have influenced streamflow trends are ground-water pumping, construction of runoff-detention structures, urbanization (increased impervious areas and diversions of runoff), and cattle ranching (grazing). 

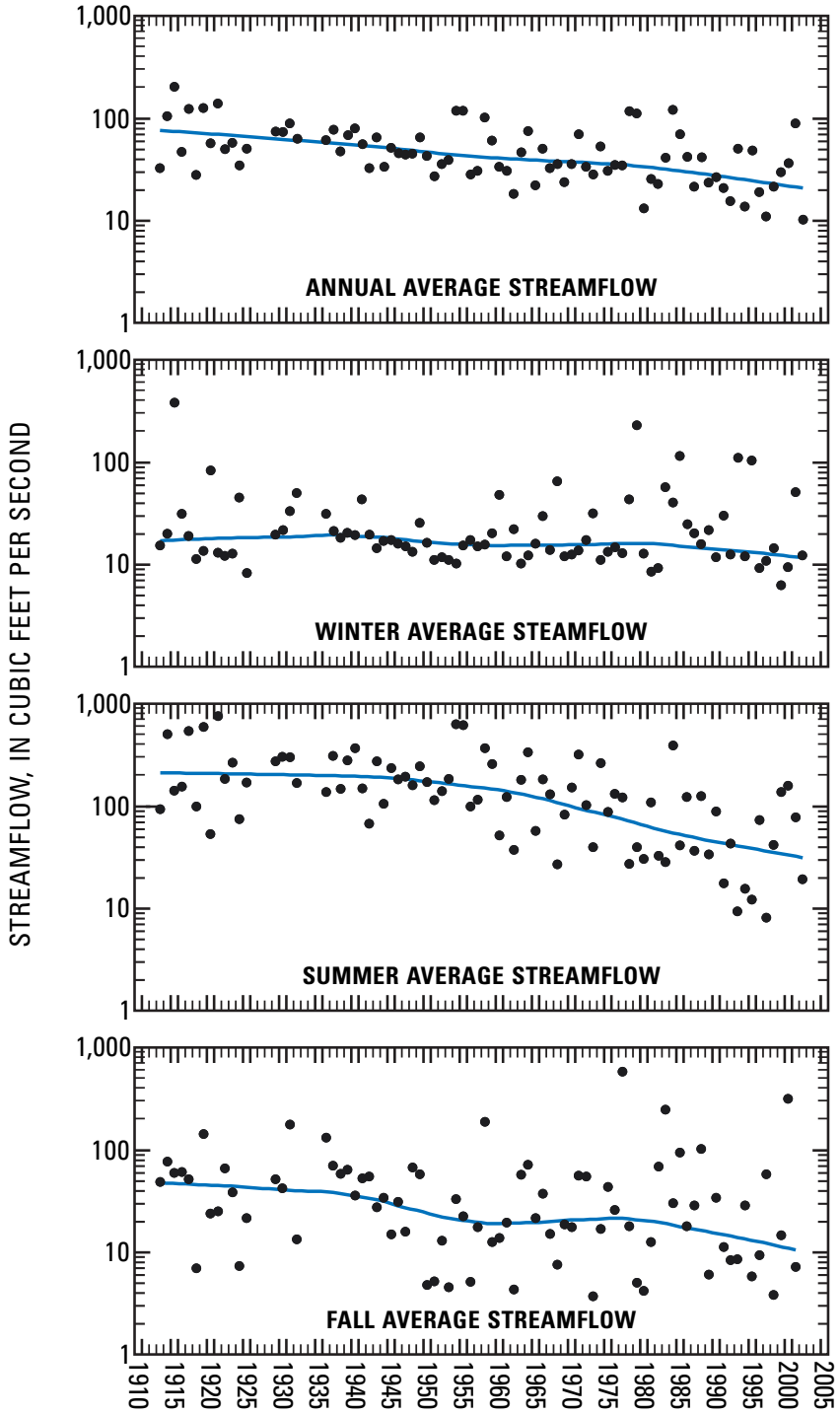

Figure 1. Trends in annual and seasonal streamflow of the San Pedro River at Charleston, Arizona. Blue line is LOWESS fit to data.

\section{Purpose and Scope}

This report presents results of a study of trends in streamflow of the San Pedro River in southeastern Arizona and regional trends in precipitation and streamflow in southeastern Arizona and southwestern New Mexico. The study objective was to improve the understanding of trends and the causes of trends in streamflow of the San Pedro River. The decreasing streamflow trends of the San Pedro River have been well documented by other studies (Hereford, 1993; Sharma and others, 1997; Stromberg, 1998; Pool and Coes, 1999; and Rojo and others, 1999), but no study has thoroughly investigated the nature and causes of the trends. Determining the causes of the decrease in streamflow is difficult because the many possible factors are interrelated and there are meager data on the historical changes in some of the factors. This study took several different approaches and used statistical analysis as the primary tool. Statistical analysis can sort out complex interactions and determine the relative importance of each factor affecting streamflow, and it provides objective measures of the strength of evidence (probabilities) for determining if trends are statistically significant or if trends occurred by chance.

The first step in the analysis was to place the trends in San Pedro River streamflow in a regional perspective. Trends in seasonal precipitation and streamflow for surrounding areas were determined and compared to trends in the San Pedro River Basin. The second step was a detailed evaluation of trends in seasonal precipitation and streamflow in the basin. The third step was to evaluate trends in monthly streamflows of the San Pedro River and to distinguish between the effects of precipitation and the effects of factors other than precipitation. The variation in streamflow caused by variation in precipitation was removed, and the remaining variation was attributed to factors other than precipitation, such as human activities or changes in watershed characteristics. The last step incorporated results of all the analyses to evaluate the specific causes of streamflow trends.

\section{Physical Setting}

The regional study area is about 7,000 $\mathrm{mi}^{2}$, and the San Pedro River Basin at Charleston, Arizona, is 1,234 $\mathrm{mi}^{2}$ (figs. 2 and 3). About $696 \mathrm{mi}^{2}$ of the basin is in Mexico. The regional boundaries were selected to include an area of similar climate and physiography as the San Pedro River Basin. The western boundary is near the Santa Cruz River Basin; areas to the west of that are much drier than the San Pedro River Basin. The northern boundary is near the southern part of the Salt River Basin; areas to the north of that are at a consistently higher elevation and are much wetter and cooler than the San Pedro River Basin. The eastern boundary extended much further than the western boundary because the climate in much of southwestern New Mexico is similar to that of the San Pedro River Basin. The eastern boundary is about 50 miles east of the Arizona-New Mexico border. The southern boundary is the upper watershed of the San Pedro River in Sonora, Mexico, and the international boundary between the United States and Mexico to the west and east of the watershed.

The regional study area (fig. 2) has a wide range of landsurface elevation, precipitation, and vegetation. Precipitation and vegetation generally correlate with elevation; precipitation increases with increased elevation, and vegetation changes from desert shrubs and cacti in the lowlands to grassland and oak woodland in the mid-elevations and conifers in the highlands. Land-surface elevations range from about 2,000 to $11,000 \mathrm{ft}$, and mean annual precipitation ranges from about $10 \mathrm{in.}$ in the lowest elevations to about $40 \mathrm{in}$. in the highest elevations. In the Upper San Pedro River Basin, land-surface elevations range from about 3,900 to $9,500 \mathrm{ft}$, and mean annual precipitation ranges from about 14 to $30 \mathrm{in}$. (fig. 3). 


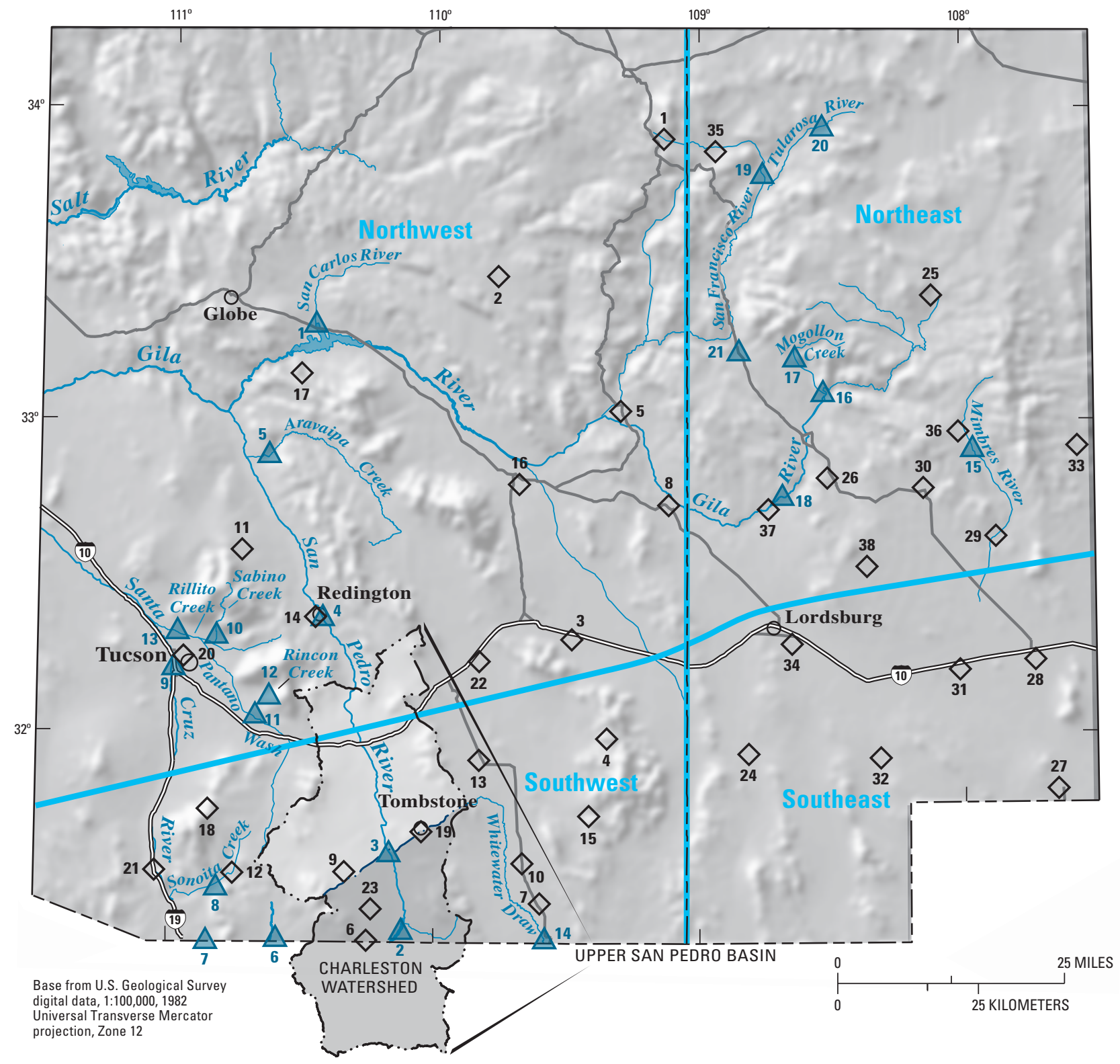

EXPLANATION

$21 \triangle$ U.S. geOlogical SURVEY

STREAMFLOW-GAGING

STATION AND NUMBER

(See table 2)

$\diamond$ NATIONAL WEATHER SERVICE

PRECIPITATION STATION

AND NUMBER (See table 1)

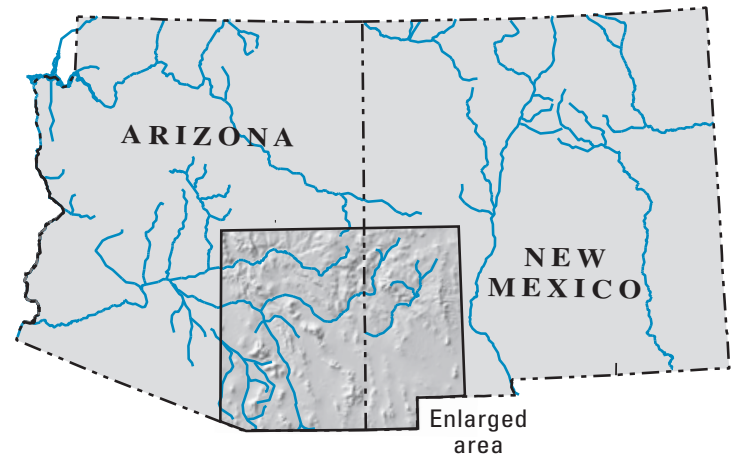

Figure 2. Location of regional study area and data-collection sites. 


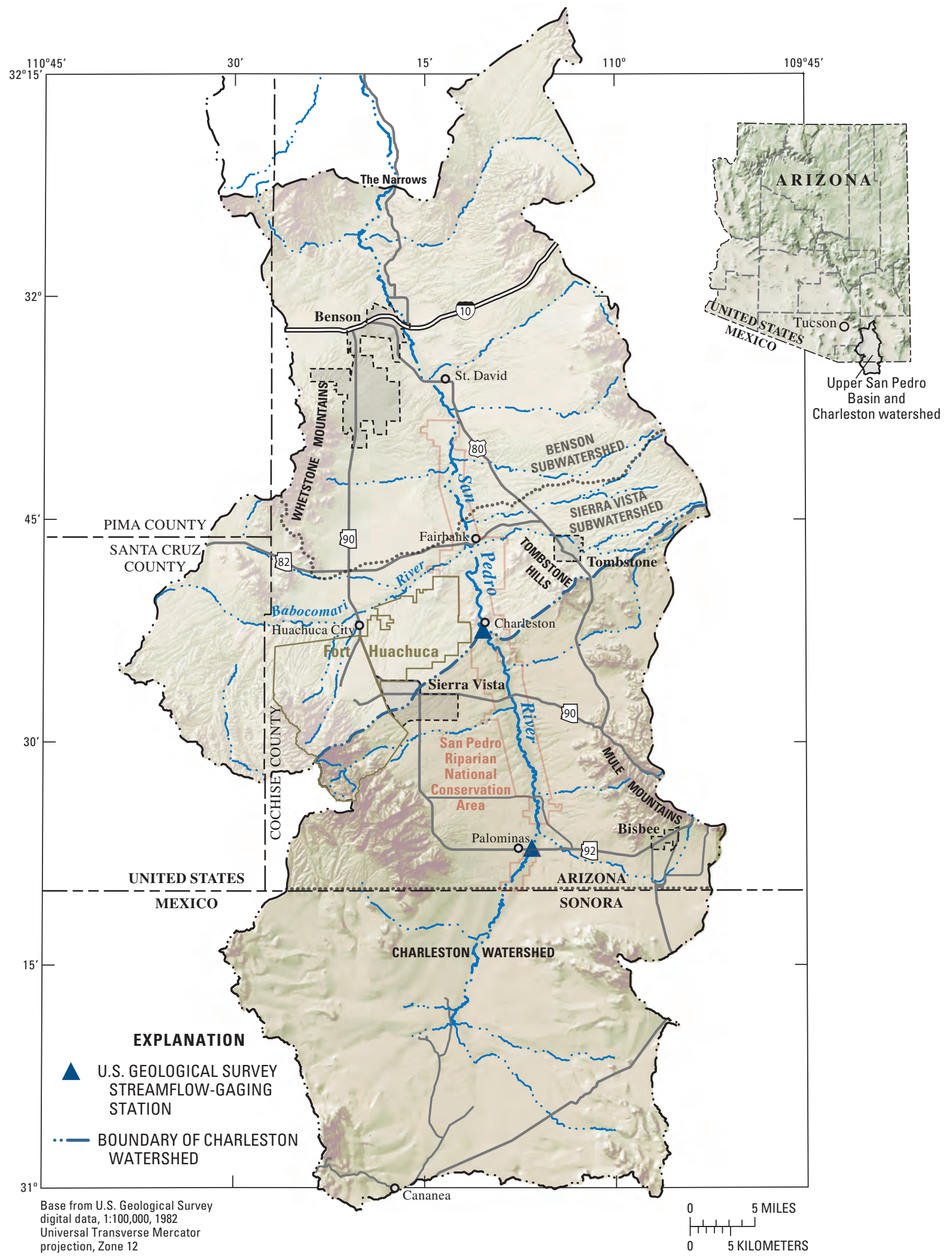

Figure 3. Location of the Upper San Pedro River Basin and Charleston watershed, southeastern Arizona and northern Sonora, Mexico. 
The climate of the study area is arid or semiarid with a biseasonal distribution of precipitation in summer and winter. Seasons have different precipitation characteristics because there are several sources of moisture and several types of storms that transport the moisture and deliver the precipitation. In the winter, mid-latitude frontal systems bring moisture from the Pacific Ocean, and the precipitation generally has a long duration, low intensity, and widespread extent. Spring is a dry transitional period, and frontal systems usually move to the north of the study area. In the summer, moisture moves into the study area from the Gulf of Mexico, Gulf of California, and Pacific Ocean, and convective thunderstorms (monsoons) deliver short-duration and high-intensity precipitation. The thunderstorms have a small spatial extent and are somewhat random in their location. Fall is a transitional period that can have precipitation from monsoonal thunderstorms, frontal systems, and dissipating tropical cyclones. Residual moisture from tropical cyclones can be carried northward with weak monsoonal flow or with cutoff low-pressure systems from the Pacific Ocean, and storms from this source can result in some of the largest and most widespread floods in the study area (Webb and others, 2004).
The southwest part of the study area (fig. 2), which includes the Upper San Pedro River Basin (fig. 3), is generally similar to the rest of the study area in its physical environment with the exception of the seasonal distribution of precipitation and streamflow. In the southwest part of the study area, percentages of annual precipitation and streamflow that occur in the summer are larger than percentages in the rest of the study area (fig. 4). In the southwest part, about 48 percent of the precipitation and 56 percent of the streamflow occur in the summer. In the rest of the study area, about 39 percent of the precipitation and 22 percent of the streamflow occur in the summer. Thus, changes in summer precipitation have a greater effect on overall water supply in the southwest part compared to the rest of the study area.

The seasonal characteristics of precipitation at Tombstone, Arizona, and streamflow of the San Pedro River are similar: most of the annual volume of water is in the summer, and the least amount of water is in the spring (fig. 5). Summer also has the largest difference between high and low streamflows.

\section{A. Precipitation}

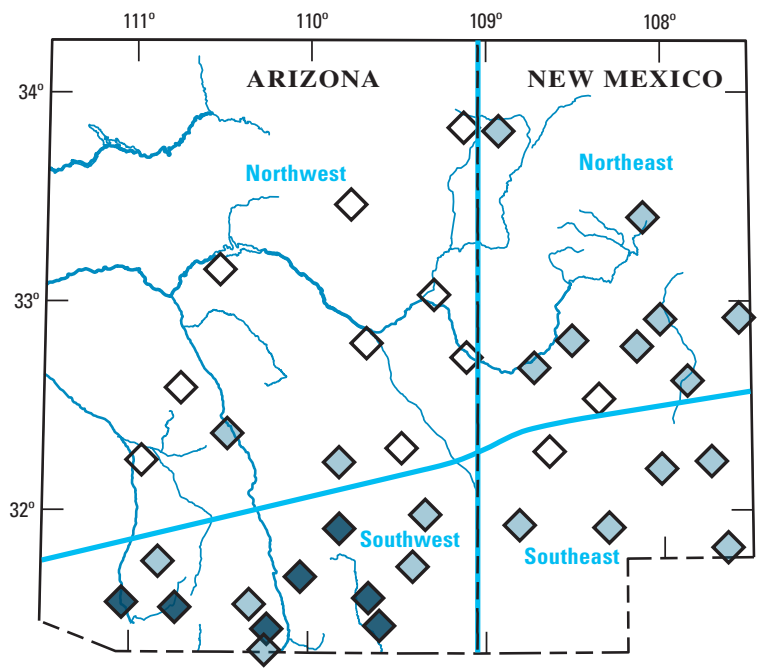

B. Streamflow

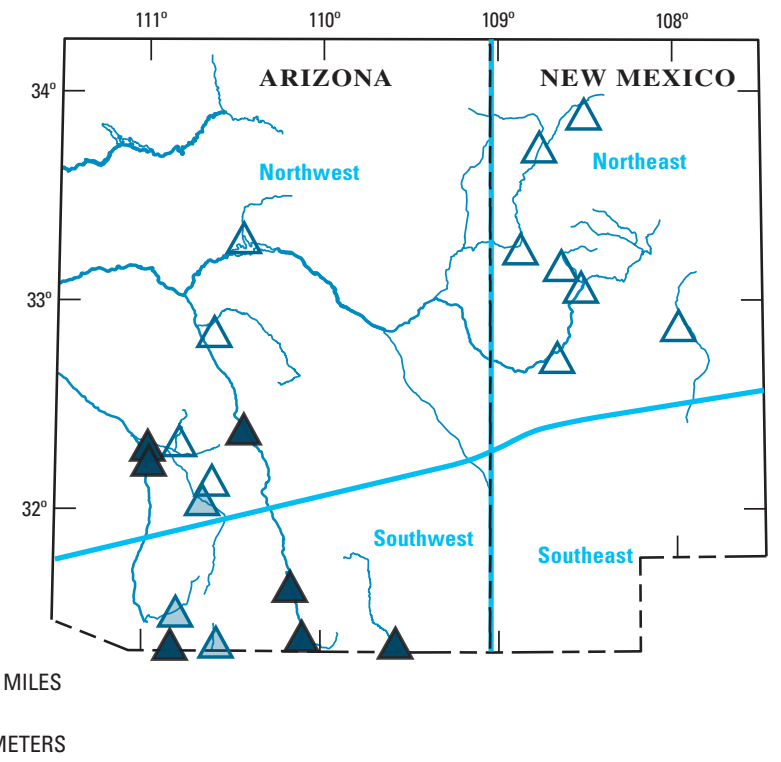

EXPLANATION

RANGE IN RATIO:

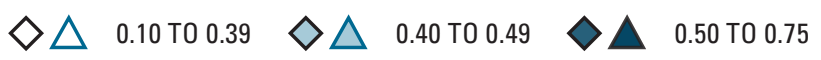

Figure 4. Ratios of summer to annual value. A, Precipitation; B, Streamflow. 
A. Average monthly precipitation

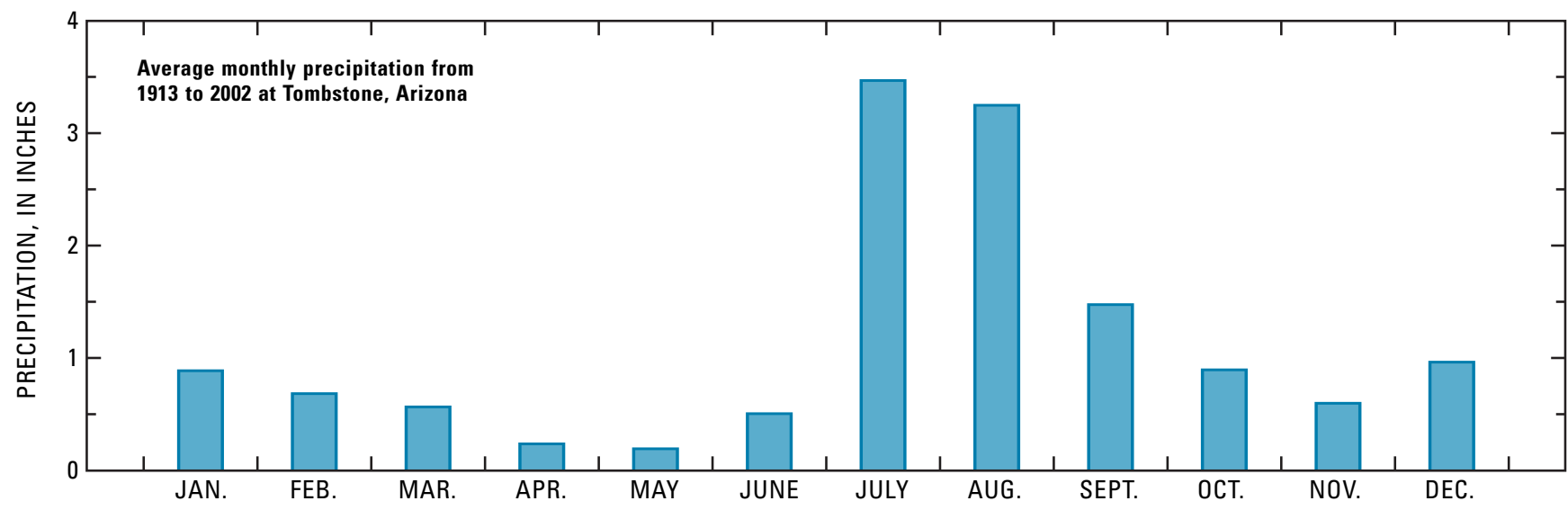

B. Daily streamflows

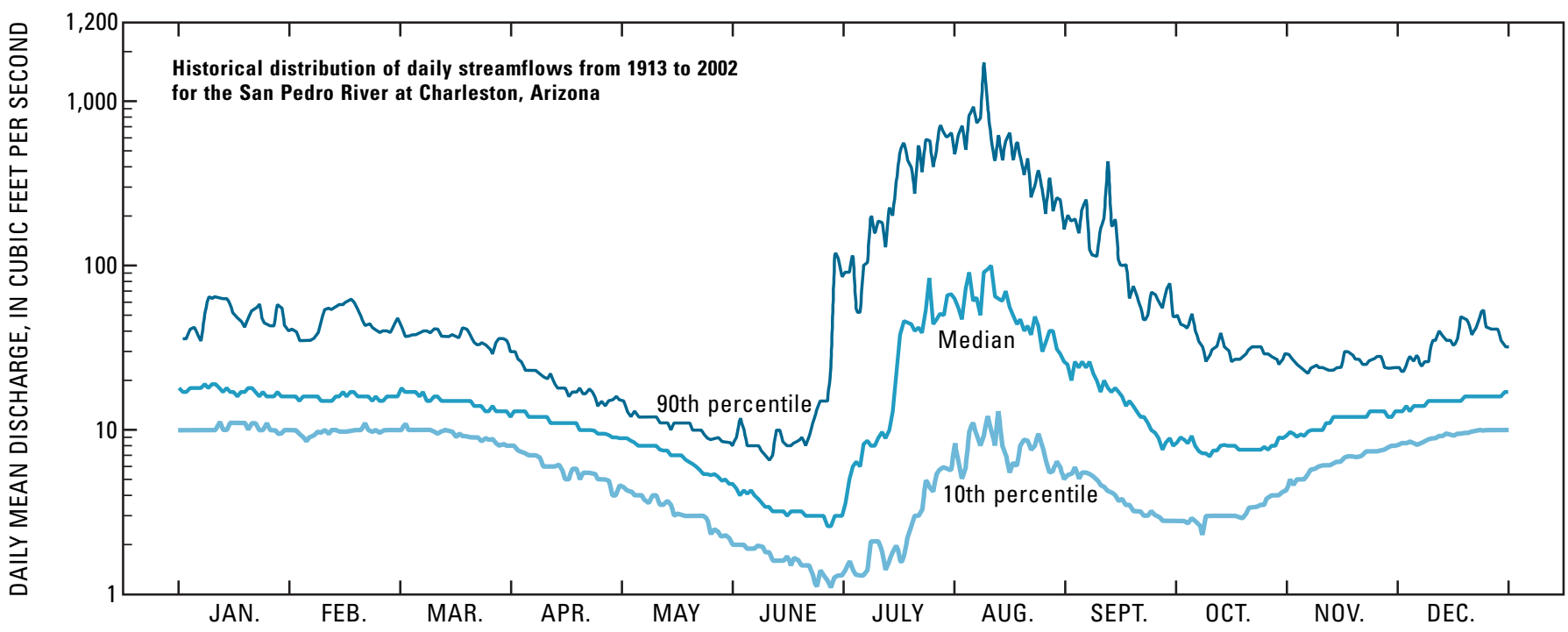

Figure 5. A, Average monthly total precipitation at Tombstone, Arizona, and $B$, Historical distribution of daily streamflows for the San Pedro River at Charleston, Arizona.

\section{Previous Studies}

In addition to the studies that have noted the large decrease in streamflow of the San Pedro River, many other studies have investigated changes or trends in precipitation and watershed characteristics during the 20th century. There were small changes in precipitation patterns and intensity, but no large changes in precipitation magnitude (Hereford, 1993; Sharma and others, 1997; Pool and Coes, 1999; and Rojo and others, 1999). Upland and riparian vegetation changed in areal extent, density, and relative proportion of different species (Hereford, 1993; Stromberg, 1998; Kepner and Edmonds, 2002; and Turner and others, 2003). Stream-channel morphology of the San Pedro River changed substantially from 1880 to 1955 (Hereford, 1993). From 1880 to 1910, the channel incised and deepened, and from 1910 to 1955, the channel migrated laterally and widened.

Several ground-water models have been constructed of the ground-water system in the Upper San Pedro Basin (Freethey, 1982; Vionnett and Maddock, 1992; Corell and others, 1996; and Goode and Maddock, 2000). These models were constructed to improve the understanding of the groundwater system and its interaction with the San Pedro River, and to estimate effects of future ground-water pumping. The models simulated changes in the ground-water and surface-water systems from a predevelopment period (prior to 1940) to the late 1970s or 1990s. Ground-water pumping caused simulated decreases in annual base flow that ranged from 33 to 65 percent of the predevelopment flow. 


\section{Methods}

\section{Regional Trends}

Regional trends in precipitation and streamflow were determined by evaluating records at 38 National Weather Service precipitation sites and 21 U.S. Geological Survey (USGS) streamflow-gaging stations (fig. 2, tables 1 and 2). Precipitation data are more complete than streamflow data. Most precipitation sites have data from 1950 to 2002, and some sites have data from 1930 or earlier. Streamflow-gaging stations have more missing data than precipitation sites, and some streams have two or more gaging stations. Only 10 gaging stations have mostly complete data from 1950 to 2002. Most of the missing streamflow data were from gaging stations that were discontinued for blocks of time within their records.

Annual and seasonal values of precipitation and streamflow were analyzed. Seasons were defined on the basis of the type of storms that cause precipitation and runoff. Winter was defined as November through March, spring was April through June, summer was July and August, and fall was September and October. In the San Pedro River Basin, about 27 percent of the annual precipitation falls in winter, 6 percent in spring, 49 percent in summer, and 18 percent in fall.

An evaluation of trends is dependent on the period of record that is evaluated. During the 20th century, precipitation and streamflow in the study area followed decadal-scale cycles of high and low values (McCabe and Dettinger, 1999). The 1950s had low precipitation and streamflow, and the 1980s had high precipitation and streamflow. Consequently, several time periods were analyzed to obtain results that were not biased by a particular position on a cycle. Trends were analyzed for 11 time periods starting every 5 years from 1930 to 1980, and ending in 2002 (for example, 1930-2002, 1935-2002, and 1940-2002).

A nonparametric Kendall tau test was used to determine if there were significant trends in precipitation or streamflow (Helsel and Hirsch, 1992, p. 326-328). The Kendall tau non-parametric test is considered more appropriate than parametric tests (such as linear regression) for precipitation and streamflow data because these data usually have many outliers that unduly influence parametric tests, and these data usually are not normally distributed. The Kendall tau test is for monotonic trends. A monotonic trend generally increases or decreases in magnitude throughout a time period. There may be short reversals of the increasing or decreasing trend, but the predominant trend is in one direction. A set of data in which the magnitudes of data steadily increase for half the time period and steadily decrease for the other half would have no monotonic trend.

Several statistical tests were made in this study and all used a threshold significance level of a p-value equal to 0.05 . A p-value less than 0.05 means the test is significant. The p-value of 0.05 is a commonly used significance level (Sokal and Rohlf, 1995, p. 163-164); however, p-values between 0.05 and 0.10 are also important and indicate a strong association. Tests with a p-value between 0.05 and 0.10 were called "nearly significant" in this report.

Results of the trend tests for the precipitation sites and streamflow-gaging stations were plotted on maps of the regional study area. The results were also summarized for five parts of the study area: the San Pedro River Basin and four quadrants—-southwest, including the San Pedro River Basin; northwest; northeast; and southeast (fig. 2). The boundaries of the four quadrants were selected on the basis of similar climatic and streamflow characteristics.

Temporal patterns or cycles in seasonal precipitation and streamflow were evaluated using typical or average values for the study area. Typical values of precipitation and streamflow were compared for the southwest part (including the San Pedro River Basin) and the rest of the study area. These two parts were compared because an objective of the study was to determine how trends in the basin compare to regional trends. Typical values were represented by computing regional normalized values from site values in the two parts. A normalized seasonal value was computed at each site by dividing each seasonal value of precipitation or streamflow by the mean for the entire record, and regional normalized values were computed by taking the mean of all the normalized seasonal values for each site.

Regional normalized precipitation was computed for the southwest part of the study area using four sites and was computed for the rest of the study area using 11 sites (table 1 and fig. 2). No regional normalized streamflow was computed for the southwest part of the study area because streamflow trends of the San Pedro River were severe and would have obscured any temporal patterns or cycles in streamflow of other streams in the southwest part. Regional normalized streamflow was computed for the rest of the study area using three sites (San Carlos River near Peridot, Arizona; Gila River near Gila, New Mexico; and San Francisco River near Glenwood, New Mexico; table 2). The precipitation and streamflow sites used for the regional normalized values were selected because they all had mostly complete records for 1931-2002 and they had similar precipitation or streamflow characteristics within their part of the study area. 
Table 1. Data-collection sites for analysis of regional trends in precipitation, southeastern Arizona and southwestern New Mexico

\begin{tabular}{|c|c|c|c|c|c|c|c|}
\hline $\begin{array}{c}\text { Map } \\
\text { number }\end{array}$ & $\begin{array}{c}\text { National } \\
\text { Weather Service } \\
\text { identification number }\end{array}$ & $\mathrm{Name}^{2}$ & State & $\begin{array}{c}\text { Period of } \\
\text { record }\end{array}$ & $\begin{array}{c}\text { Years } \\
\text { of data }\end{array}$ & $\begin{array}{c}\text { Land-surface } \\
\text { elevation } \\
\text { (feet) }\end{array}$ & $\begin{array}{c}\text { Mean annual } \\
\text { precipitation }^{3} \\
\text { (inches) }\end{array}$ \\
\hline 1 & 0159 & Alpine $^{4}$ & Arizona & $1931-2002$ & 72 & 8,050 & 20.5 \\
\hline 2 & 0808 & Black River Pumphouse & Arizona & $1947-2002$ & 56 & 6,040 & 16.2 \\
\hline 3 & 0958 & Bowie $^{4}$ & Arizona & $1931-2002$ & 65 & 3,760 & 11.5 \\
\hline 4 & 1664 & Chiricahua National Monument & Arizona & 1948-2002 & 55 & 5,300 & 19.5 \\
\hline 6 & 2140 & Coronado National Monument & Arizona & 1956-2002 & 47 & 5,242 & 20.9 \\
\hline 7 & 2664 & Douglass FAA Airport & Arizona & 1948-2002 & 55 & 4,150 & 13.0 \\
\hline 8 & 2754 & Duncan & Arizona & $1942-2002$ & 61 & 3,660 & 11.2 \\
\hline 9 & 3120 & Fort Huachuca & Arizona & 1955-1997 & 43 & 4,670 & 15.1 \\
\hline 13 & 6353 & Pearce Sunsites & Arizona & 1953-2002 & 43 & 4,350 & 12.2 \\
\hline 14 & 7036 & Redington & Arizona & 1942-2002 & 60 & 2,940 & 13.8 \\
\hline 15 & 7334 & Rucker Canyon ${ }^{5}$ & Arizona & $1931-2002$ & 72 & 5,370 & 19.0 \\
\hline 16 & 7390 & Safford Ag Center & Arizona & 1949-2002 & 54 & 2,954 & 9.2 \\
\hline 17 & 27480 & San Carlos Reservoir & Arizona & 1931-1997 & 67 & 2,530 & 15.5 \\
\hline 18 & 27593 & Santa Rita Experiment Range & Arizona & 1950-2002 & 53 & 4,300 & 22.3 \\
\hline 19 & 8619 & Tombstone $e^{5}$ & Arizona & $1905-2002$ & 93 & 4,610 & 13.6 \\
\hline 20 & 28815 & Tucson, University of Arizona ${ }^{4}$ & Arizona & $1901-2002$ & 102 & 2,440 & 11.6 \\
\hline 21 & 28865 & Tumacacori National Monument & Arizona & 1946-2002 & 57 & 3,270 & 15.8 \\
\hline 28 & 2436 & Deming $^{4}$ & New Mexico & ${ }^{6} 1901-2002$ & 93 & 4,300 & 9.5 \\
\hline 29 & 3157 & Faywood & New Mexico & 1946-2002 & 55 & 5,190 & 11.6 \\
\hline 30 & 3265 & Fort Bayard ${ }^{4}$ & New Mexico & $1931-2002$ & 72 & 6,140 & 15.2 \\
\hline 31 & 3368 & Gage 4 ESE & New Mexico & $1901-2002$ & 100 & 4,410 & 10.2 \\
\hline 32 & 3775 & Hachita & New Mexico & 1931-2002 & 70 & 4,510 & 10.5 \\
\hline 33 & 4009 & Hillsboro $^{4}$ & New Mexico & $1905-2002$ & 84 & 5,270 & 12.7 \\
\hline 34 & 5079 & Lordsburg $4 \mathrm{SE}^{4}$ & New Mexico & $1931-2001$ & 71 & 4,250 & 11.6 \\
\hline 35 & 5273 & Luna Ranger Station ${ }^{4}$ & New Mexico & $1931-2002$ & 72 & 7,050 & 15.9 \\
\hline 36 & 5754 & Mimbres Ranger Station & New Mexico & 1931-1997 & 67 & 6,240 & 17.3 \\
\hline 37 & 7340 & Redrock $^{4}$ & New Mexico & $1931-2002$ & 68 & 4,150 & 12.9 \\
\hline 38 & 9691 & White Signal & New Mexico & 1949-2002 & 54 & 6,070 & 15.2 \\
\hline
\end{tabular}

${ }^{1}$ See figure 2 .

${ }^{2}$ All sites were operated by the National Weather Service.

${ }^{3}$ Values are for 1950-2002, or for period of record if the period began after 1950.

${ }^{4}$ Site was used in the analysis of regional normalized precipitation in northwest, northeast, and southeast part of study area (fig. 8).

${ }^{5}$ Site was used in the analysis of regional normalized precipitation in southwest part of study area (fig. 8).

${ }^{6}$ Site has more than 10 years of missing data in a continuous block of time within period of record. 
Table 2. Data-collection sites for analysis of regional trends in streamflow, southeastern Arizona and southwestern New Mexico [nr, near; NA, data not available]

\begin{tabular}{|c|c|c|c|c|c|c|c|c|}
\hline $\begin{array}{c}\text { Map } \\
\text { number }^{1}\end{array}$ & $\begin{array}{l}\text { Gaging- } \\
\text { station } \\
\text { number }\end{array}$ & Name $^{2}$ & State & $\begin{array}{l}\text { Period of } \\
\text { record }\end{array}$ & $\begin{array}{l}\text { Years } \\
\text { of data }\end{array}$ & $\begin{array}{l}\text { Drainage area } \\
\text { (square miles) }\end{array}$ & $\begin{array}{c}\text { Mean } \\
\text { basin } \\
\text { elevation } \\
\text { (feet) }\end{array}$ & $\begin{array}{c}\text { Mean annual } \\
\text { precipitation }^{3} \\
\text { (inches) }\end{array}$ \\
\hline 1 & 09468500 & San Carlos River nr Peridot & Arizona & $1930-2002$ & 73 & 1,026 & 4,480 & 17.2 \\
\hline 2 & 09470500 & San Pedro River at Palominas & Arizona & ${ }^{4} 1931-2002$ & 46 & 737 & 4,950 & 17.9 \\
\hline 3 & 09471000 & San Pedro River at Charleston & Arizona & $1913-2002$ & 86 & 1,234 & 4,840 & 16.5 \\
\hline 5 & 09473000 & Aravaipa Creek nr Mammoth & Arizona & ${ }^{4} 1932-2002$ & 46 & 537 & 4,530 & 16.2 \\
\hline 6 & 09480000 & Santa Cruz River nr Lochiel & Arizona & $1950-2002$ & 53 & 82.2 & 5,150 & 18.2 \\
\hline 7 & 09480500 & Santa Cruz River nr Nogales & Arizona & 1931-2002 & 70 & 533 & 4,850 & 18.7 \\
\hline 8 & 09481500 & Sonoita Creek nr Patagonia & Arizona & 1931-1972 & 40 & 209 & 4,800 & 19.3 \\
\hline 9 & 09482500 & Santa Cruz River at Tucson & Arizona & ${ }^{4} 1913-2002$ & 75 & 2,222 & 4,050 & 16.9 \\
\hline 13 & 09485850 & Rillito Creek nr Tucson & Arizona & $1914-1975$ & 61 & 892 & 4,400 & 15.5 \\
\hline 14 & 09537500 & Whitewater Draw nr Douglas & Arizona & 1931-1982 & 48 & 1,023 & 4,740 & 14.8 \\
\hline 15 & 08477000 & Mimbres River nr Mimbres & New Mexico & 1931-1976 & 46 & 152 & 5,972 & NA \\
\hline 16 & 09430500 & Gila River nr Gila & New Mexico & 1929-2002 & 74 & 1,864 & 8,100 & 18.0 \\
\hline 17 & 09430600 & Mogollon Creek nr Cliff & New Mexico & $1968-2002$ & 35 & 69.0 & NA & NA \\
\hline 18 & 09431500 & Gila River nr Redrock & New Mexico & $1931-2002$ & 65 & 2,829 & 6,280 & 17.0 \\
\hline 19 & 09442680 & San Francisco River nr Reserve & New Mexico & $1960-2002$ & 43 & 350 & 5,820 & 17.0 \\
\hline 20 & 09442692 & Tularosa River abv Aragon & New Mexico & 1967-1996 & 30 & 94.0 & 7,720 & 13.0 \\
\hline 21 & 09444000 & San Francisco River nr Reserve & New Mexico & 1928-2002 & 75 & 1,653 & 4,560 & 17.6 \\
\hline
\end{tabular}

${ }^{1}$ See figure 2.

${ }^{2}$ All gaging stations were operated by the U.S. Geological Survey.

${ }^{3}$ Precipitation is the mean for the entire drainage basin and is based mostly on 1931-1960 data.

${ }^{4}$ Gaging station has more than 10 years of missing data in a continuous block of time within period of record.

\section{Trends in the San Pedro River Basin}

Trends in the San Pedro River Basin were analyzed in more detail than the trends in the regional study area. Trends in seasonal precipitation and streamflow were evaluated, trends in monthly streamflow caused by factors other than precipitation were evaluated, and causes of trends were evaluated. Trends from 1913 to 2002 were evaluated using precipitation data from the National Weather Service site at Tombstone, Arizona, and streamflow data from the USGS gaging station San Pedro River at Charleston, Arizona (station 09471000). These sites were used because they have the longest and most complete data records in the San Pedro River Basin.

The gaging station for San Pedro River at Charleston was moved three times during 1913 to 2002, but it has been at the same location since 1943. The analyses presented in this report were done on the complete record from 1913 to 2002. There is some uncertainty, however, about the possible effects of the different station locations on the trend analyses. These effects were primarily evaluated by performing the same analyses on the data since 1943 and comparing those results to the results from the analyses on the complete data set. The evaluation found minor changes in trends and effects of factors other than precipitation, but the overall conclusions were the same. The evaluation of the effects of station location on the trend analyses is shown in appendix 1 .

\section{Trends in Precipitation and Streamflow}

Monotonic trends in monthly and seasonal precipitation from 1913 to 2002 were evaluated to determine possible seasonal differences, and monotonic trends for shorter time periods during 1913 to 2002 were evaluated to determine possible changes in trends over time. Changes in streamflow from the predevelopment period to 2002 were evaluated to determine the overall decrease in flow during the time of human influences on the streamflow record. The period prior 
to 1940 is generally considered the predevelopment period (Corell and others, 1996; Rojo and others, 1999). Streamflow records at Palominas (09470500), Charleston (09471000), and Redington (09472000; fig. 2 and table 2) were analyzed for different time periods to provide insight into the causes of trends. Finally, step trends or shifts in precipitation and streamflow were evaluated to gain a better understanding of the characteristics of the trends.

Monotonic trends in precipitation were determined using the Kendall tau test. For trends in seasonal precipitation, measures of the total volume, maximum value, frequency, and volume per storm were evaluated. Total volume was total inches, maximum value was maximum daily precipitation, frequency was number of days with precipitation, and volume per storm was total volume divided by number of days with precipitation.

Step trends in seasonal precipitation and streamflow were evaluated to provide additional information on the changes over time. Monotonic trend tests incorporate all the increasing, level, or decreasing trends or cycles in a record and provide a summary statistic of the overall trend for the entire period of record. Possible cycles or step trends within the record are lost or obscured in this type of analysis. To evaluate step trends or cycles in seasonal precipitation and streamflow, the years of data were grouped into six successive time periods and measures of the central tendency and variability were computed for each time period. The six time periods were selected so each period has about an equal number of years (about 14). The central tendency was represented by the median value, and the variability was represented by the interquartile range (IQR). The IQR is the difference between the 75 th percentile and 25 th percentile of the data. Two types of seasonal data were used in the step-trend analysis: (1) total precipitation or streamflow for each year in the time period and (2) maximum daily precipitation or streamflow for each year in the time period. The median and IQR for each season were computed using the 14 values in each time period. Thus, these medians and IQRs measure the interannual central tendency and variability.

To normalize the results for comparison between precipitation and streamflow, the medians and IQRs for each time period were divided by the median or IQR for the entire record. All four seasons were analyzed, but only winter, summer, and fall values are discussed because spring precipitation and streamflow are a small percentage of the volume or maximum values for the year.

\section{Trends in Streamflow Caused by Factors Other than Precipitation}

The last and most detailed analysis of streamflow of the San Pedro River was of trends in monthly values of total flow, low flow, and storm runoff, and of trends in these streamflow components that were caused by factors other than precipitation. Analysis of trends in monthly values and different streamflow components provides information about the cause of trends, because the influence of each human activity and each watershed characteristic is different depending on the month of the year and the streamflow component. Pumping from the regional ground-water system should have a constant effect on low flows and total flows throughout all months of the year, and have little effect on storm runoff. Vegetation and associated transpiration have a much larger effect on streamflow during the warm summer months than during the cool winter months.

The three components of streamflow analyzed in this study (total flow, low flow, and storm runoff) were represented as follows: (1) total flow was the average flow for each month, (2) low flow was the 3-day low flow for each month, and (3) storm runoff was the maximum daily mean flow for each month with direct runoff from precipitation. The 3-day low flow can be considered an index of regional ground-water discharge, but it can also include flow from local bank storage and discharge from the local alluvial ground-water system. Several methods are available to estimate base flow or groundwater discharge, but all have some limitations, and the 3-day low flow was used because it is unbiased, repeatable, and not dependent on assumptions. Average flows and storm runoff were analyzed for the entire record (1913-2002). Low flows were analyzed for 1931-2002, because data for daily low flows during 1913-30 were not considered sufficiently accurate. Low flows for several consecutive days were often averaged into a single value in the streamflow record.

The monthly 3-day low flow is used as an approximation of monthly base flow of the San Pedro River. Base flow has sometimes been confused with an estimate of all the ground water that moves to a stream and discharges to a stream. Base flow, as used in this study and in the groundwater models of the Upper San Pedro Basin (Freethey, 1982; Vionnett and Maddock, 1992; Corell and others, 1996; Goode and Maddock, 2000), is the actual flow in the river that is sustained by ground-water discharge. The total quantity of ground water that moves to the San Pedro River equals base flow plus water that is removed by evapotranspiration from shallow ground water in the flood plain and near the stream channel.

The record of storm-runoff peaks was not complete for most months during 1913 to 2002 . The analysis was intended for actual storm runoff-mostly overland flow of water from an intense storm that causes a steep rise in the hydrograph of daily flows. Almost every year had at least one storm-runoff peak during the summer months, but many years could go by where precipitation was not sufficient to generate storm runoff during the other months. To construct a record of storm-runoff peaks for each month, the annual hydrographs of daily mean flows for all years in the record were evaluated, and stormrunoff peaks were selected from the appearance of sharp peaks of runoff. This procedure resulted in a complete record for August (84 peaks), one missing peak for July (83 peaks), 71 peaks for September, about 35 peaks for June and October, about 20 peaks for November to March, and fewer than 10 peaks for April and May.

Possible trends in San Pedro River streamflow caused by factors other than precipitation were determined by partitioning the temporal variation in streamflow into two parts: (1) the variation caused by variation in precipitation and (2) the variation caused by other factors, such as human activities and changes in watershed characteristics. The variation in streamflow caused by factors other than precipitation was then tested for trends. 
The partitioning of the variation in streamflow and testing to determine trends in the streamflow variation caused by factors other than precipitation was done using two methods: (1) regression analysis between precipitation and streamflow for all years in the record and evaluation of time trends in regression residuals, and (2) development of regression equations between precipitation and streamflow for three time periods (early, middle, and late parts of the record) and testing to determine if the three regression equations are significantly different. Method 1 is an evaluation of monotonic change for the entire record, and method 2 is an evaluation of step changes during three time periods in the record.

\section{Monotonic Trends}

The first method was a four-step method of regression modeling and monotonic trend testing (Helsel and Hirsch, 1992, p. 323-337). The first step was to develop regression relations between precipitation and streamflow for the monthly streamflow components using all years in the record (about 80 data pairs for each month). The residuals from the regression analysis represent streamflow values that have had the variation caused by variation in precipitation removed. The second step was to test for monotonic trends in the residuals over time using a Kendall tau test; trends in these residuals can be attributed to factors other than precipitation.

A potential limitation or shortcoming of this method is that a drift or trend in precipitation over time could cause a bias in the relation between the regression residuals and time, and the test of the relation between regression residuals and time could lose some statistical power. Careful attention to the results of the regression analysis and the third and fourth steps in the method were used in this study to mitigate this possible shortcoming. All the regression equations were thoroughly evaluated to ensure the residuals had no bias or trend compared to the predicted streamflow values. The third step in the method, developed by Alley (1988), was to remove the effect of precipitation on time. The variation in time caused by trends in precipitation was removed using regression analysis between precipitation and time. The fourth step was to perform a Kendall tau test of monotonic trend using the precipitation-streamflow residual as the $\mathrm{Y}$ variable and the precipitation-time residual as the $\mathrm{X}$ variable. This fourth step has more statistical power than step two, and the relation between precipitation-streamflow residuals and precipitationtime residuals is free of the influence of precipitation (the degree of the removal of influence is related to the accuracy of the regression analyses in the first and third steps).

The relation between precipitation at Tombstone and streamflow of the San Pedro River is not linear for most monthly flows, so a locally weighted regression-smoothing technique was used to determine the fitted values and residuals for trend analysis. The technique called locally weighted scatterplot smoothing (LOWESS) was used (Cleveland, 1979; Helsel and Hirsch, 1992). A multiple-variable form of LOWESS was used (Insightful, 2001) to provide enough flexibility to explain variation in streamflow. In LOWESS, a different weighted least-squares regression is used to compute each fitted value. The weights for each equation are a function of a user specified window width and the magnitude of the residual from the previous regression. The window width (called a span in the software used in this study; Insightful, 2001) specifies the number of data points that are used to fit the equation. A larger span will, therefore, have a smoother fitted model than a smaller span. A span of 0.60 indicates that 60 percent of the data are used to fit each equation.

For monthly total flow and low flow, the explanatory variables investigated in the LOWESS analyses were months of precipitation for the same month as streamflow and for different combinations of 9 previous months of precipitation. For storm runoff (a daily flow), the explanatory variables investigated were precipitation for the day of runoff and several combinations of precipitation for up to 60 days previous to the day of runoff (for example days 1-5, days 1-10, days 11-30, and days 31-60). LOWESS analysis and the same explanatory variables for precipitation also were used for the regression of precipitation versus time.

\section{Step Trends}

The second method used to determine trends in streamflow caused by factors other than precipitation was to split the streamflow record into three time periods (early, middle, and late), develop monthly regression relations between precipitation and streamflow for each time period, and determine if the regression relations for the three time periods were significantly different. A change in the regression equations (precipitation-streamflow relations) between the time periods indicates a step change in streamflow caused by factors other than precipitation.

This test of step trends in the precipitation-streamflow relation over time was done on monthly total streamflow (average flow) and on storm runoff (maximum daily mean flow for each month). Low flows were not tested because this method uses a single explanatory variable of precipitation to explain streamflow, and single-variable equations could not be developed to sufficiently explain low flows.

A simple test is available to determine if regression relations are significantly different. This test must be performed on linear regression relations developed by the least-squares technique. The relation between precipitation and streamflow is not linear for most monthly flows; however, the relation is only nonlinear on the margins of the data, and the relation can be made linear by removing some precipitation-streamflow data pairs at low and high values of precipitation. These outliers were removed for the analysis; the removal is justified because most of the data remain in the analysis, and most of the data that were removed were for low values of precipitation where there was no runoff or response of streamflow. Thus, it is a test of the precipitation-runoff relation for values of precipitation that have runoff, but it is not a test of the complete precipitation-streamflow relation. More information about the data that were removed is presented in the "Step Trends" section on pages 46-47 and in "Appendix 2 " of this report. 
The statistical test used for determining differences in regression relations over time was a nested $\mathrm{F}$ test (Helsel and Hirsch, 1992, p. 315-319; Ott, 1993, p. 716-721). This is similar to an analysis of covariance in which regression and analysis of variance are combined into one test. A simple model (1) is developed between precipitation and streamflow, then a more complex model (2) is developed by adding in variables for time, and the most complex model (3) is developed by adding interaction terms between precipitation and time. Streamflow and precipitation are continuous variables and time is a discrete variable used to represent the three time periods.

The streamflow record was divided into three time periods so that about an equal number of years were in each time period. The optimum time periods were 1913-42, 1943-76, and 1977-2002. Because of missing data (mostly missing precipitation values), the three time periods for a given month typically had an unequal number of years. A random procedure was used to remove data so that an equal number of data pairs were in each time period. This was done to eliminate any potential unequal weighting and unequal variance for time periods or bias in the results (Tabachnick and Fidell, 2001, p. 46-47).

The following equations were used to determine if there were significant differences in the regression equations developed for three time periods. The three regression equations can be combined into the following equations using two dummy or binary variables $\left(T_{1}\right.$ and $\left.T_{2}\right)$ :

$$
\begin{aligned}
& Q=B_{0}+B_{1} P+E, \\
& Q=B_{0}+B_{1} P+B_{2} T_{1}+B_{3} T_{2}+E, \\
& Q=B_{0}+B_{1} P+B_{2} T_{1}+B_{3} T_{2}+B_{4} P T_{1}+B_{5} P T_{2}+E,
\end{aligned}
$$

where

$$
\begin{array}{rll}
Q & = & \text { streamflow, } \\
P & = & \text { precipitation, } \\
T_{1} \text { and } T_{2} & = & \text { dummy variables representing three time } \\
& & \text { periods, } \\
P T_{1} \text { and } P T_{2} & =\quad \begin{array}{l}
\text { interaction terms between precipitation } \\
\text { and time }
\end{array} \\
B_{0} & =\quad \text { regression intercept }, \\
B_{1-5}= & \text { regression coefficients, and } \\
E & =\text { error term. }
\end{array}
$$

The first step is to determine if there is a significant difference in slopes of the regression equations for the three time periods. This is done by comparing models 2 and 3 . The interaction terms in model 3 represent the regression slopes.

The models are statistically compared using a nested $F$ statistic:

$$
F=\frac{\left(S S E_{s}-S S E_{c}\right) /\left(d f_{s}-d f_{c}\right),}{\left(S S E_{c} / d f_{c}\right)}
$$

The $s$ subscript refers to the simpler model (fewer explanatory variables) and the $c$ subscript refers to the more complex model (more explanatory variables). The SSE is the error sums of squares and $d f$ is the degrees of freedom.

If the $F$ statistic is significant (p-value $<0.05$ ) in comparing models 2 and 3 , then model 3 is a significant improvement on model 2 and the regression slopes are significantly different. A second step is to determine if the regression intercepts are significantly different. A test of differences in regression intercepts is similar to an analysis of covariance. If the regression slopes are significantly different, then the test of intercepts cannot be performed because an assumption of the intercepts test is that the slopes are equal for all time periods. The test of regression intercepts is to compare models 1 and 2. This is the same nested $F$ test as the test for slopes; the complex model is model 2 and the simple model is model 1.

\section{Regional Trends}

Regional trends in precipitation and streamflow were evaluated for about a 7,000- $\mathrm{mi}^{2}$ study area in southeastern Arizona and southwestern New Mexico (fig. 2). By most measures of precipitation and streamflow in the regional analysis, the San Pedro River Basin is similar to other basins in the southwest part of the study area and is generally not similar to basins in the rest of the study area. The southwest part of the study area includes the San Pedro River Basin, the Whitewater Draw Basin to the east, and the Santa Cruz River Basin to the west.

\section{Trends in Precipitation}

Seasonal and annual precipitation had no trends for most of the 11 analyzed time periods; 92 percent of the 1,760 trend tests performed on individual sites were not significant (table 3). The trends that were detected were related to time periods and seasons. Most significant trends in winter and spring precipitation were for time periods that started during the mid-century drought in 1945-60. Most significant trends in summer precipitation were for time periods that started during 1930-50. Significant trends in annual precipitation were more widespread across time periods and were found in time periods starting during 1930-65. Ninety percent of the 147 significant trends in precipitation were positive. Summer precipitation had most of the significant negative trends; a few other negative trends were scattered in other seasons.

Precipitation trends in the southwest part of the study area were generally different from trends in the rest of the study area, and trends in the San Pedro River Basin were similar to trends at other sites in the southwest part of the study area (fig. 6 and table 3). The difference between the southwest part and the rest of the study area is most pronounced in annual precipitation. Ninety-five percent of the 97 trend tests on annual precipitation were not significant in the southwest part of the study area, and 28 percent of the 255 trend tests were significantly positive in the rest of the study area. 
Table 3. Regional trends in precipitation for 11 time periods, 1930-2002, southeastern Arizona and southwestern New Mexico

\begin{tabular}{|c|c|c|c|c|c|c|c|c|c|c|c|c|}
\hline Season $^{1}$ & $\begin{array}{c}\text { Part of } \\
\text { study area }\end{array}$ & \multicolumn{11}{|c|}{$\begin{array}{l}\text { Percentage of sites with significant trend }(\mathrm{p} \text {-value }<0.05)^{3} \\
(\mathrm{p} \text { is positive trend and } \mathrm{n} \text { is negative trend) } \\
\text { Starting year for trend test (data for tests end in } 2002)^{4}\end{array}$} \\
\hline \multirow[t]{4}{*}{ Winter } & San Pedro River Basin 5 & 0 & 0 & 0 & 0 & 0 & 0 & 0 & 0 & 0 & 0 & 0 \\
\hline & southwest & 0 & 0 & 0 & 0 & $11 \mathrm{p}$ & $8 \mathrm{p}$ & 0 & 0 & 0 & 0 & 0 \\
\hline & northeast & 0 & 0 & 0 & $13 \mathrm{p}$ & $22 \mathrm{p}$ & $11 \mathrm{p}$ & 0 & 0 & 0 & 0 & 0 \\
\hline & southeast & 0 & 0 & 0 & $17 \mathrm{p}$ & $33 \mathrm{p}$ & $17 \mathrm{p}$ & 0 & 0 & 0 & 0 & 0 \\
\hline \multirow[t]{2}{*}{ Spring } & San Pedro River Basin 5 & 0 & 0 & 0 & $50 \mathrm{p}$ & 0 & 0 & $75 \mathrm{p}$ & 0 & 0 & 0 & 0 \\
\hline & southwest & 0 & 0 & 0 & $33 \mathrm{p}$ & 0 & $8 \mathrm{p}$ & $50 \mathrm{p}$ & 0 & 0 & 0 & 0 \\
\hline \multirow[t]{5}{*}{ Summer } & San Pedro River Basin ${ }^{5}$ & $100 \mathrm{n}$ & $100 \mathrm{n}$ & $50 \mathrm{n}$ & $50 \mathrm{n}$ & $50 \mathrm{n}$ & $25 \mathrm{n}$ & 0 & 0 & 0 & $25 \mathrm{p}$ & 0 \\
\hline & southwest & $25 \mathrm{n}$ & $25 \mathrm{n}$ & $20 \mathrm{n}$ & $17 \mathrm{n}$ & $22 \mathrm{n}$ & $8 \mathrm{n}$ & 0 & 0 & 0 & $9 \mathrm{p}$ & 0 \\
\hline & northwest & 0 & $40 \mathrm{p}$ & $25 \mathrm{p}$ & $11 \mathrm{p}$ & 0 & 0 & $9 \mathrm{p}$ & 0 & 0 & 0 & 0 \\
\hline & northeast & $80 \mathrm{p}$ & $80 \mathrm{p}$ & $50 \mathrm{p}$ & $50 \mathrm{p}$ & $22 \mathrm{p}$ & $11 \mathrm{p}$ & $22 \mathrm{p}$ & 0 & 0 & 0 & 0 \\
\hline & southeast & $20 \mathrm{p}$ & $40 \mathrm{p}$ & 0 & 0 & 0 & 0 & 0 & 0 & 0 & 0 & 0 \\
\hline \multirow[t]{3}{*}{ Fall } & San Pedro River Basin 5 & 0 & 0 & 0 & 0 & 0 & 0 & 0 & 0 & 0 & 0 & 0 \\
\hline & southwest & 0 & 0 & 0 & 0 & $11 \mathrm{p}$ & 0 & $8 \mathrm{p}$ & 0 & 0 & 0 & 0 \\
\hline & northwest & 0 & 0 & 0 & 0 & 0 & 0 & $9 \mathrm{n}$ & 0 & 0 & 0 & 0 \\
\hline \multirow{2}{*}{ Annual } & northeast & $60 \mathrm{p}$ & $60 \mathrm{p}$ & $67 \mathrm{p}$ & $100 \mathrm{p}$ & $78 \mathrm{p}$ & $33 \mathrm{p}$ & $11 \mathrm{p}$ & $22 \mathrm{p}$ & 0 & 0 & 0 \\
\hline & southeast & 0 & $20 \mathrm{p}$ & $17 \mathrm{p}$ & $67 \mathrm{p}$ & $50 \mathrm{p}$ & $33 \mathrm{p}$ & $17 \mathrm{p}$ & $17 \mathrm{p}$ & 0 & 0 & 0 \\
\hline
\end{tabular}

Number of sites with data for significance testing Starting year for trend test (data for all tests end in 2002) ${ }^{4}$

\begin{tabular}{|c|c|c|c|c|c|c|c|c|c|c|c|}
\hline \multirow[b]{2}{*}{ Part of study area ${ }^{2}$} & \\
\hline & 1930 & 1935 & 1940 & 1945 & 1950 & 1955 & 1960 & 1965 & 1970 & 1975 & 1980 \\
\hline southwest & 4 & 4 & 5 & 6 & 9 & 12 & 12 & 12 & 11 & 11 & 11 \\
\hline northwest & 5 & 5 & 8 & 9 & 11 & 11 & 11 & 11 & 11 & 11 & 11 \\
\hline northeast & 5 & 5 & 6 & 8 & 9 & 9 & 9 & 9 & 9 & 9 & 9 \\
\hline
\end{tabular}

${ }^{1}$ Winter is November-March, spring is April-June, summer is July-August, and fall is September-October.

${ }^{2}$ See figure 2.

${ }^{3} \mathrm{~A}$ Kendall tau trend test was made on seasonal and annual total precipitation.

${ }^{4}$ Most sites have data through 2002. Three sites have data ending in 1997, and one site has data ending in 2001.

${ }^{5}$ San Pedro River Basin is in the southwest part of the study area, and it includes precipitation sites 6, 9, 19, and 23 (table 1). 
A. Winter

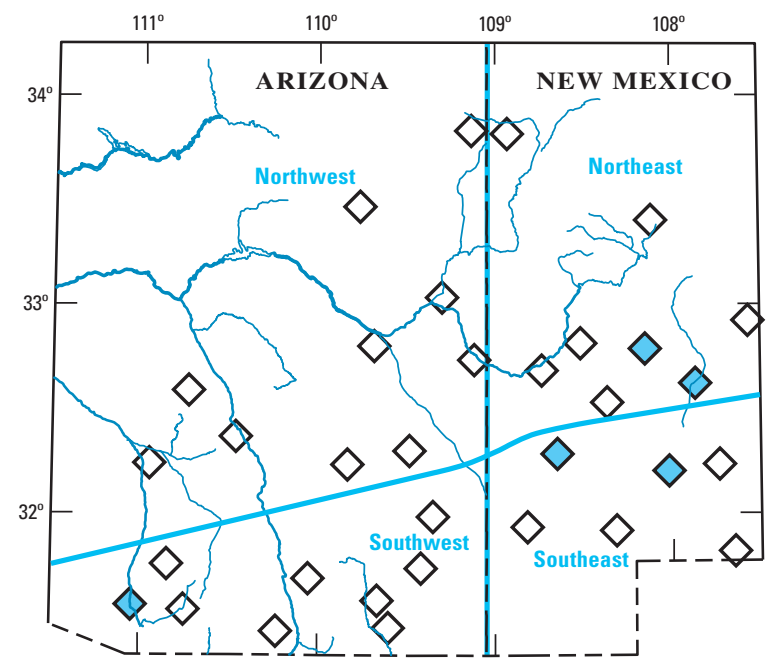

C. Annual

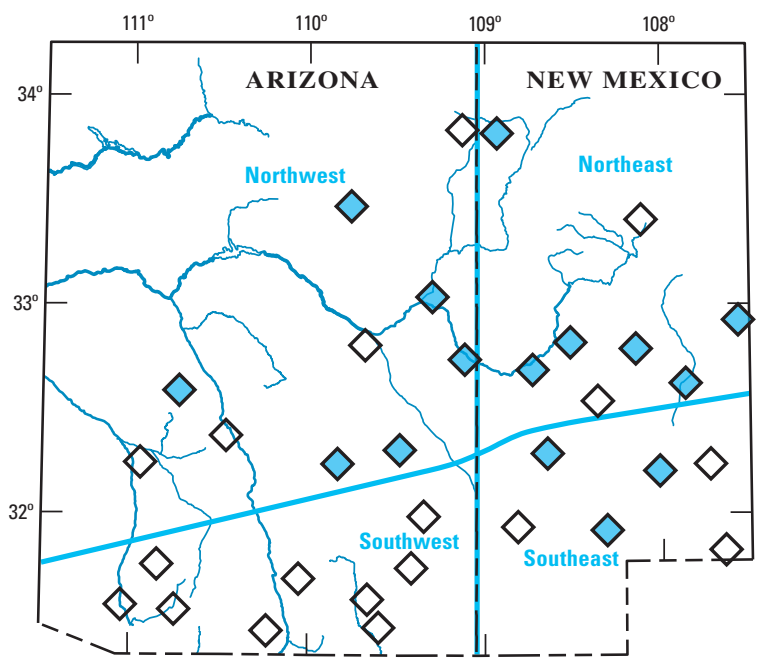

B. Summer

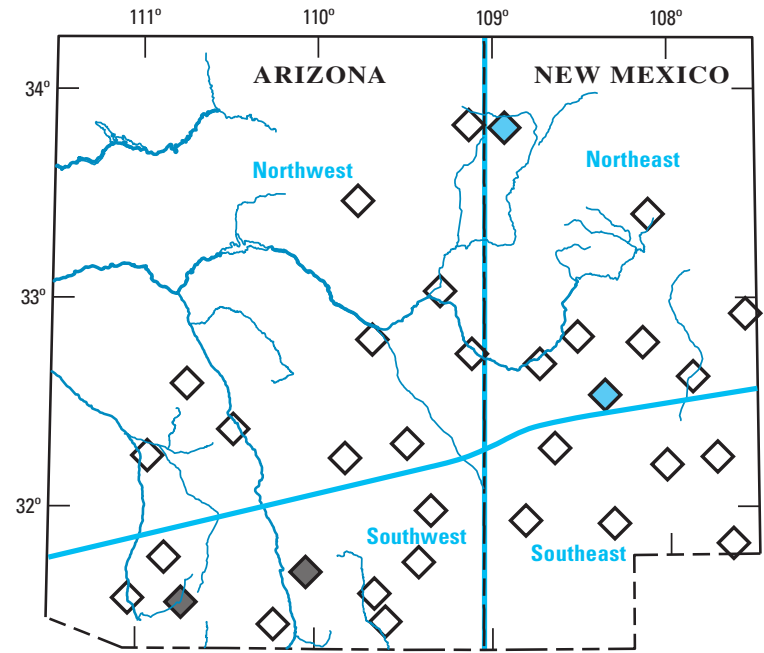

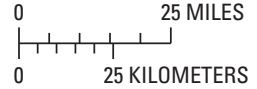

EXPLANATION

SIGNIFICANT TREND- $p$-value

less than 0.05:

$\diamond$ NONE

$\diamond$ POSITIVE

$\diamond$ NEgATIVE

Figure 6. Regional trends in precipitation, 1950-2002. A, Winter; B, Summer; C, Annual.

\section{Trends in Streamflow}

The analysis of regional trends in streamflow was limited by the incomplete records and spatial distribution of streamflow data in the study area. Whereas 21 gaging stations had at least 25 years of data, only 6 stations had complete records that could be used for a rigorous analysis of regional trends during 1930-2002 (table 4). There were 10 gaging stations on 4 rivers (table 2), so 6 of those stations could not be used because of spatial correlation. Another 9 stations were not used because the records had large blocks of time when the stations were discontinued. The streamflow data from the 15 gaging stations not used for the rigorous regional comparison were still evaluated, but with attention to their limitations (table 5).

Seasonal and annual streamflow had no trends for most of the 11 analyzed time periods; 79 percent of the 330 trend tests performed on individual sites were not significant (table 4). The time periods that did have significant streamflow trends were not as clustered about the mid-century drought as were the significant trends for precipitation. Sixty-six percent of the significant trends were for time periods that started before 1955. Most significant trends in winter, spring, fall, and annual flows were positive, and 95 percent of the significant trends in summer flows were negative. 
Table 4. Trends in seasonal and annual total streamflow at 6 gaging stations for 11 time periods, 1930-2002, southeastern Arizona and southwestern New Mexico

$[<$, less than; nr, near; AZ, Arizona; NM, New Mexico; NA, data are not sufficient for significance testing $(<20$ years)]

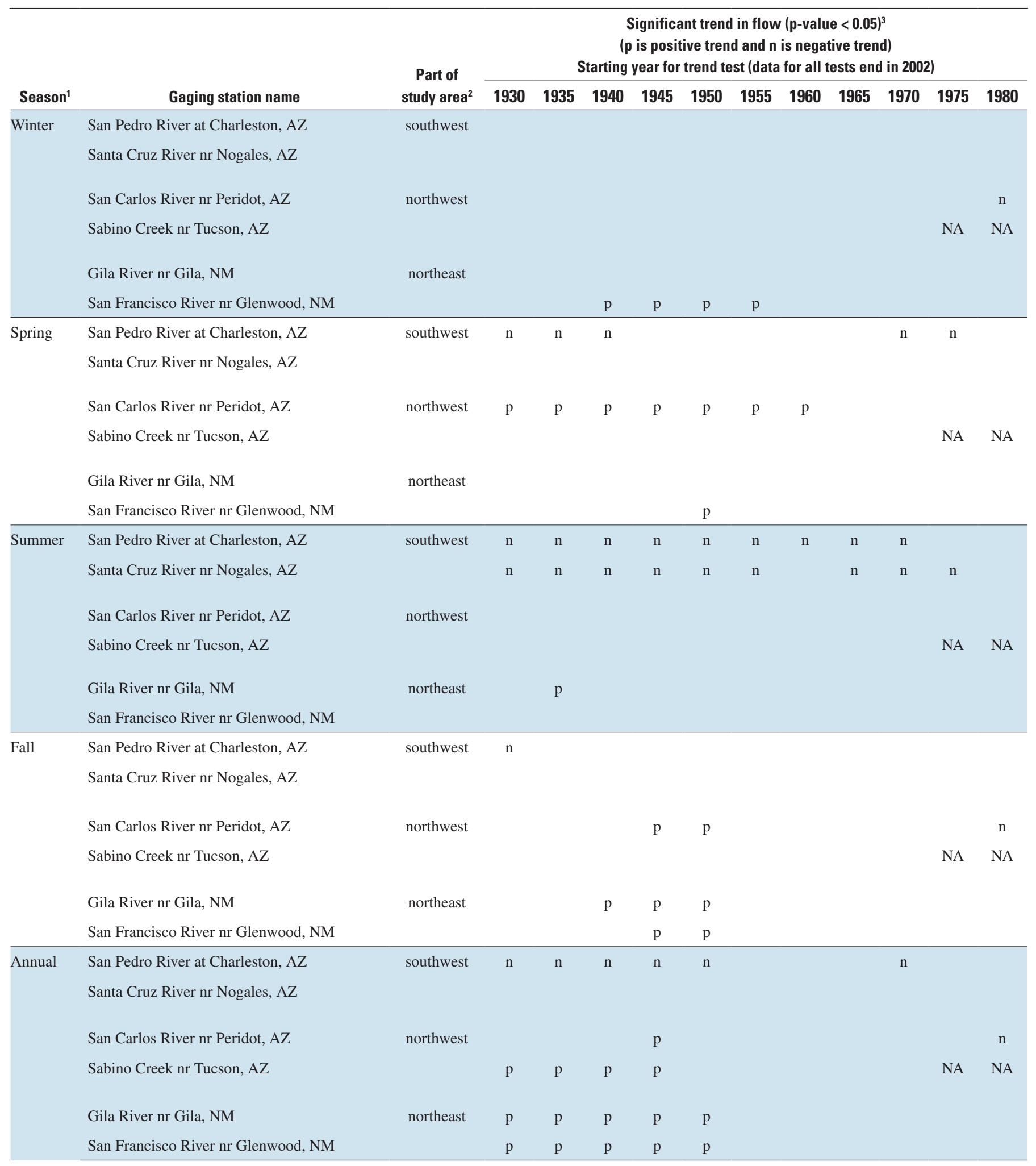

${ }^{1}$ Winter is November-March, spring is April-June, summer is July-August, and fall is September-October.

${ }^{2}$ See figure 2.

${ }^{3} \mathrm{~A}$ Kendall tau trend test was made on seasonal and annual average streamflow. 
Table 5. Trends in seasonal and annual total streamflow at 21 gaging stations for periods of record, southeastern Arizona and southwestern New Mexico

[<, less than; Slp, slope; nr, near; Riv, river; Cr, creek; >, greater than]

\begin{tabular}{|c|c|c|c|c|c|c|c|c|c|c|c|c|c|}
\hline \multirow{3}{*}{$\begin{array}{c}\text { Part of } \\
\text { study area }\end{array}$} & \multirow{3}{*}{$\begin{array}{c}\text { Map } \\
\text { no. }\end{array}$} & \multirow[b]{3}{*}{ Gaging-station name } & \multirow{3}{*}{$\begin{array}{l}\text { Period of } \\
\text { record }\end{array}$} & \multicolumn{10}{|c|}{ Kendall tau trend test ${ }^{2}$} \\
\hline & & & & \multicolumn{2}{|c|}{ Winter $^{3}$} & \multicolumn{2}{|c|}{ Spring $^{3}$} & \multicolumn{2}{|c|}{ Summer ${ }^{3}$} & \multicolumn{2}{|c|}{ Fall ${ }^{3}$} & \multicolumn{2}{|c|}{ Annual } \\
\hline & & & & SIp ${ }^{4}$ & p-value & SIp ${ }^{4}$ & p-value & SIp ${ }^{4}$ & p-value & SIp ${ }^{4}$ & p-value & SIp ${ }^{4}$ & p-value \\
\hline \multirow[t]{6}{*}{ southwest } & 2 & San Pedro Riv at Palominas & ${ }^{5} 1931-2002$ & $\mathrm{n}$ & 0.032 & $\mathrm{n}$ & 0.041 & $\mathrm{n}$ & 0.024 & $\mathrm{n}$ & 0.295 & $\mathrm{n}$ & 0.049 \\
\hline & 3 & San Pedro Riv at Charleston & $1913-2002$ & $\mathrm{n}$ & .132 & $\mathrm{n}$ & .042 & $\mathrm{n}$ & $<.001$ & $\mathrm{n}$ & .011 & $\mathrm{n}$ & $<.001$ \\
\hline & 6 & Santa Cruz Riv nr Lochiel & 1950-2002 & $\mathrm{p}$ & .004 & $\mathrm{p}$ & $<.001$ & $\mathrm{n}$ & .175 & $\mathrm{p}$ & .575 & $\mathrm{p}$ & .581 \\
\hline & 7 & Santa Cruz Riv nr Nogales & $1931-2002$ & $\mathrm{n}$ & .792 & $\mathrm{n}$ & .601 & $\mathrm{n}$ & .005 & $\mathrm{p}$ & .959 & $\mathrm{p}$ & .980 \\
\hline & 8 & Sonoita Cr nr Patagonia & $1931-1972$ & $\mathrm{p}$ & .322 & $\mathrm{p}$ & .152 & $\mathrm{n}$ & .470 & $\mathrm{n}$ & 699 & $\mathrm{p}$ & 1.000 \\
\hline & 9 & Santa Cruz Riv at Tucson & ${ }^{5} 1913-2002$ & $\mathrm{p}$ & .742 & $\mathrm{p}$ & .014 & $\mathrm{n}$ & .035 & $\mathrm{p}$ & .538 & $\mathrm{n}$ & .202 \\
\hline \multirow{5}{*}{ northwest } & 5 & Aravaipa Cr nr Mammoth & ${ }^{5} 1932-2002$ & $\mathrm{p}$ & .405 & $\mathrm{p}$ & .029 & $\mathrm{n}$ & .222 & $\mathrm{n}$ & .883 & $\mathrm{p}$ & .501 \\
\hline & 10 & Sabino Cr nr Tucson & ${ }^{5} 1933-2002$ & $\mathrm{p}$ & .695 & $\mathrm{p}$ & .240 & $\mathrm{p}$ & .220 & $\mathrm{p}$ & .194 & $\mathrm{p}$ & .046 \\
\hline & 11 & Pantano Wash nr Vail & ${ }^{5} 1960-2002$ & $\mathrm{n}$ & .314 & $\mathrm{p}$ & .953 & $\mathrm{n}$ & .228 & $\mathrm{n}$ & .073 & $\mathrm{n}$ & .260 \\
\hline & 12 & Rincon Cr nr Tucson & ${ }^{5} 1953-2002$ & $\mathrm{p}$ & .662 & $\mathrm{p}$ & .361 & $\mathrm{n}$ & .307 & $\mathrm{p}$ & .354 & $\mathrm{p}$ & .892 \\
\hline & 13 & Rillito Cr nr Tucson & $1914-1975$ & $\mathrm{n}$ & .501 & $\mathrm{n}$ & .107 & $\mathrm{n}$ & .013 & $\mathrm{n}$ & .544 & $\mathrm{n}$ & .058 \\
\hline \multirow[t]{2}{*}{ northeast } & 15 & Mimbres Riv nr Mimbres & $1931-1976$ & $\mathrm{n}$ & .373 & $\mathrm{n}$ & .272 & $\mathrm{n}$ & .872 & $\mathrm{p}$ & .883 & $\mathrm{n}$ & .857 \\
\hline & 16 & Gila Riv nr Gila & 1929-2002 & $\mathrm{p}$ & .236 & $\mathrm{n}$ & .889 & $\mathrm{p}$ & .487 & $\mathrm{p}$ & .197 & $\mathrm{p}$ & .152 \\
\hline
\end{tabular}

${ }^{1}$ See figure 2.

${ }^{2}$ Trend test was made on seasonal and annual average streamflow.

${ }^{3}$ Winter is November-March, spring is April-June, summer is July-August, and fall is September-October.

${ }^{4}$ Slope of trend: $\mathrm{n}$ is negative and $\mathrm{p}$ is positive.

${ }^{5}$ Gaging station has more than 10 years of missing data in a continuous block of time within period of record.

\begin{tabular}{|c|l|l|}
\cline { 3 - 3 } \multicolumn{2}{c|}{} & p-value \\
\hline $\mathrm{n}$ or $\mathrm{p}$ & no significant trend & $>0.10$ \\
\hline $\mathrm{n}$ & nearly significant negative trend & $0.05-0.10$ \\
\hline $\mathrm{n}$ & significant negative trend & $<0.05$ \\
\hline $\mathrm{p}$ & nearly significant positive trend & $0.05-0.10$ \\
\hline $\mathrm{p}$ & significant positive trend & $<0.05$ \\
\hline
\end{tabular}


Geographic patterns in streamflow trends were similar to the geographic patterns in precipitation trends - streamflow trends of the San Pedro River Basin were generally similar to streamflow trends of other streams in the southwest part of the study area, and trends in the southwest part were different from trends in the rest of the study area (fig. 7 and tables 4 and 5). The two rivers in the southwest part that had complete records-San Pedro River and Santa Cruz River-had consistently different trends from rivers in the rest of the study area. The San Pedro and Santa Cruz Rivers had consistent negative summer trends, and other streams had no summer trends. For annual flows, the San Pedro River had a negative trend, the Santa Cruz River had no trend, and the rest of the study area had no trends or positive trends.

\section{A. Winter}

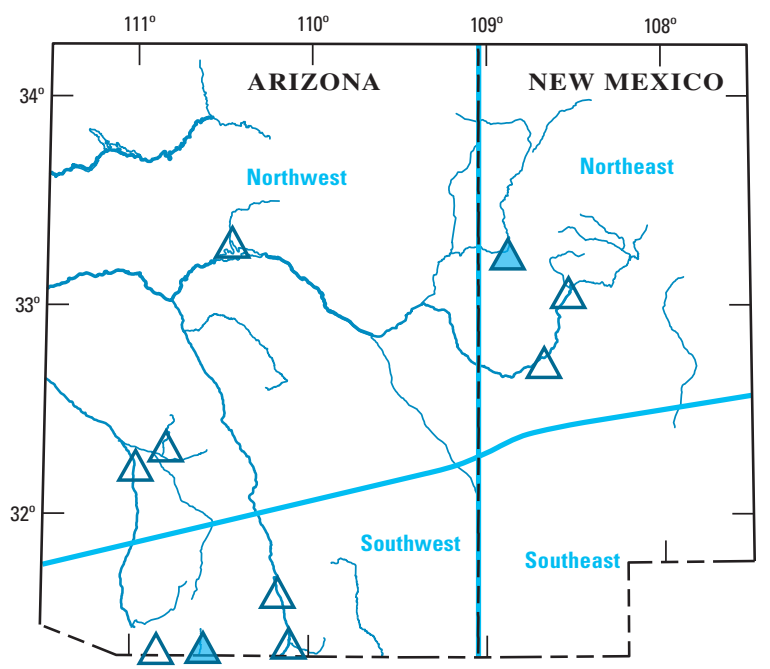

C. Annual

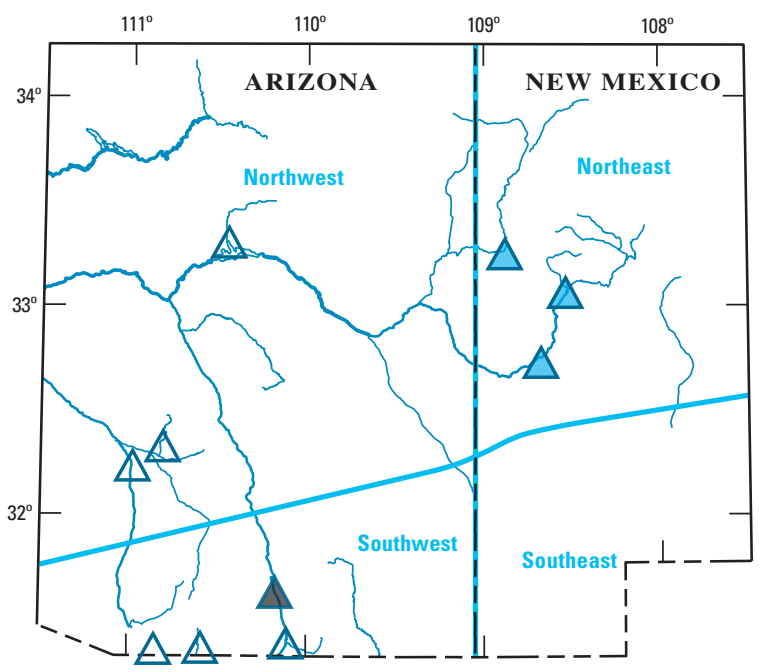

The patterns of the trends in streamflow at the six gaging stations with complete records were also found in the trends for the gaging stations that did not have complete and consistent records (table 5). Whitewater Draw is the next major watershed to the east of the San Pedro Basin. It had data only from 1931 to 1982 , but it had similar streamflow trends as the San Pedro River. All seasons except summer had significant negative trends, and the p-value for summer trends was nearly significant at 0.081 . Streamflow at other stations with incomplete records in the northwest and northeast parts of the study area had few significant trends, but most significant trends at the six stations with complete records were for time periods starting in 1930-50 and ending in 2002, and the records at these other stations did not cover that time period.

\section{B. Summer}

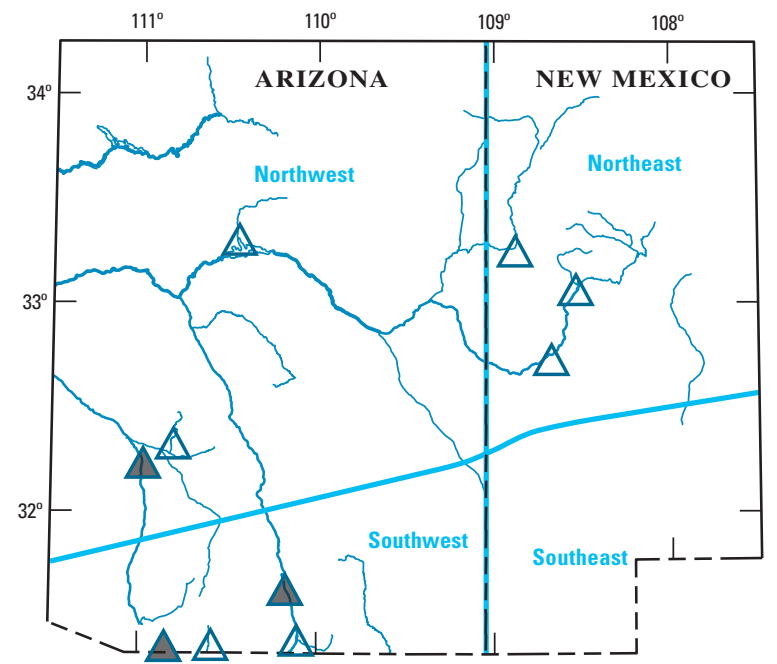

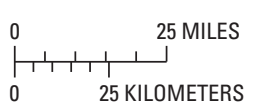

EXPLANATION

SIGNIFICANT TREND- $p$-value

less than 0.05:

$\triangle$ NONE

$\triangle$ POSITIVE

$\triangle$ NEgATIVE

Figure 7. Regional trends in streamflow, 1950-2002. A, Winter; $B$, Summer; $C$, Annual. 
The decreasing trends in summer flows for Whitewater Draw, the San Pedro River, and the Santa Cruz River could have similar causes. The three watersheds had similar historical changes: upland vegetation changed from primarily grasslands to mostly mesquite woodlands, riparian vegetation increased substantially, and ground-water pumping increased substantially (Turner and others, 2003; Robert H. Webb, U.S. Geological Survey, oral commun., 2004).

\section{Temporal Patterns or Cycles in Precipitation and Streamflow}

There are long-term temporal patterns or cycles in precipitation and streamflow in the study area. Understanding these cycles is important because (1) the cycles influence long-term changes in water supply, vegetation, and other watershed characteristics, (2) the cycles tend to repeat and their magnitude and duration can be used for land- and watermanagement decisions, and (3) trend analyses are strongly affected by the cycles.

Long-term patterns or cycles in precipitation from 1930 to 2002 are shown in graphs of regional normalized precipitation for the study area (fig. 8). Regional normalized values are an average of the long-term data in the region. Winter and spring precipitation had much more pronounced cycles than did summer or fall precipitation. Winter and spring precipitation were generally high in the 1930s, low in the 1950s and 1960s, high in the 1980s, and low in the late 1990s and early 2000s. The seasons had different interannual variability; spring and fall precipitation had the most variability, winter had moderate variability, and summer had small variability.

The normalized precipitation trends for the southwest part of the study area generally followed the same patterns as the normalized trends for the rest of the study area. The only notable difference was in summer precipitation from 1930 to 2002 ; summer precipitation appeared to decrease slightly in the southwest part and increase slightly in the rest of the study area.

Long-term cycles in streamflow from 1930 to 2002 are shown using normalized values for the San Pedro River at Charleston and regional normalized values for the northwest and northeast parts of the study area (fig. 9). Regional normalized streamflow for winter, spring, and fall in the northwest and northeast parts of the study area had long-term patterns similar to those in the precipitation data. A big difference between precipitation and streamflow in those areas was in the summer: summer precipitation had no apparent cycles and small interannual variability, and summer streamflow had large cycles and large interannual variability.

In contrast to the pronounced streamflow cycles in the northwest and northeast parts of the study area, streamflow in the San Pedro River mostly just decreased steadily. Precipitation in all parts of the study area had long-term cycles, and the influence of those precipitation cycles appears in streamflow in the northeast and northwest parts of the study area but not in streamflow of the San Pedro River. This lack of response to precipitation cycles is one indication that other factors besides precipitation could be affecting streamflow of the San Pedro River.

Effects of the recent drought (about the past 5 years) appear as decreasing trends in many of the plots of normalized precipitation and streamflow for all parts of the study area (figs. 8 and 9). There are downturns from 1990 to 2002 in precipitation and streamflow for both winter and spring. Effects of the drought do not appear in summer precipitation in any part of the study area, and other seasonal precipitation and streamflow show mixed effects. 
NORMALIZED PRECIPITATION FOR SOUTHWEST PART OF STUDY AREA (4 SITES)
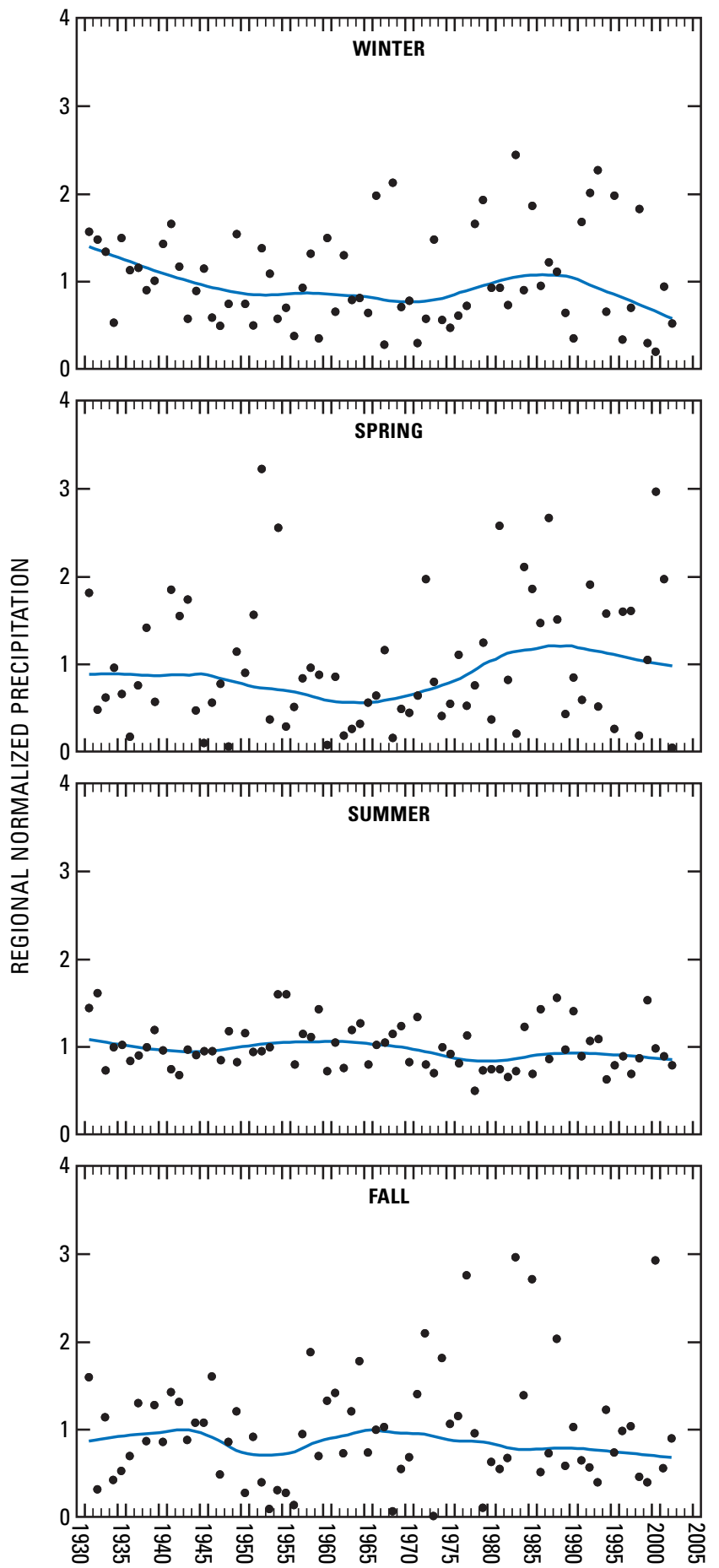

NORMALIZED PRECIPITATION FOR NORTHWEST, NORTHEAST, AND SOUTHEAST PARTS OF STUDY AREA (11 SITES)
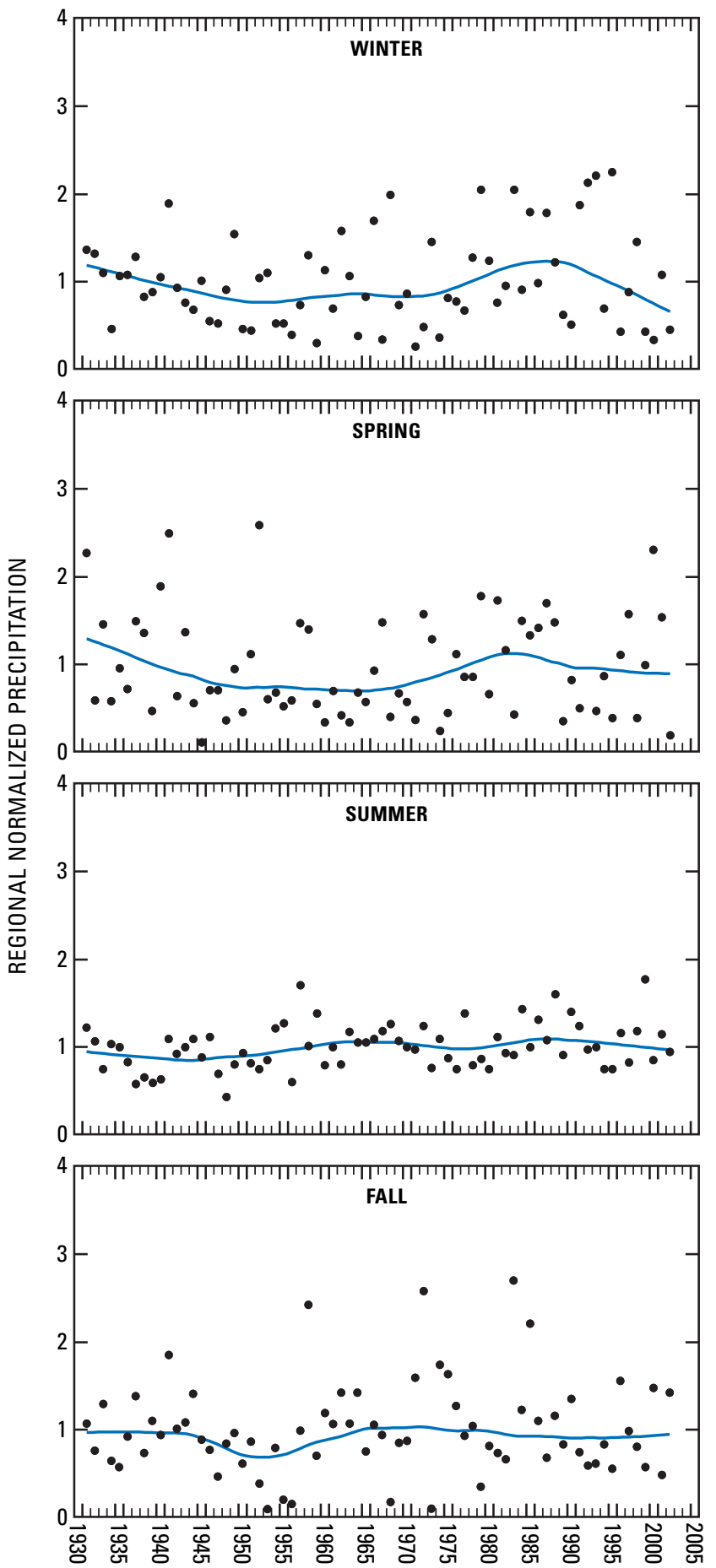

Figure 8. Trends in regional normalized seasonal precipitation, southeastern Arizona and southwestern New Mexico. Blue line is LOWESS fit to data. 
NORMALIZED STREAMFLOW FOR

SAN PEDRO RIVER AT CHARLESTON
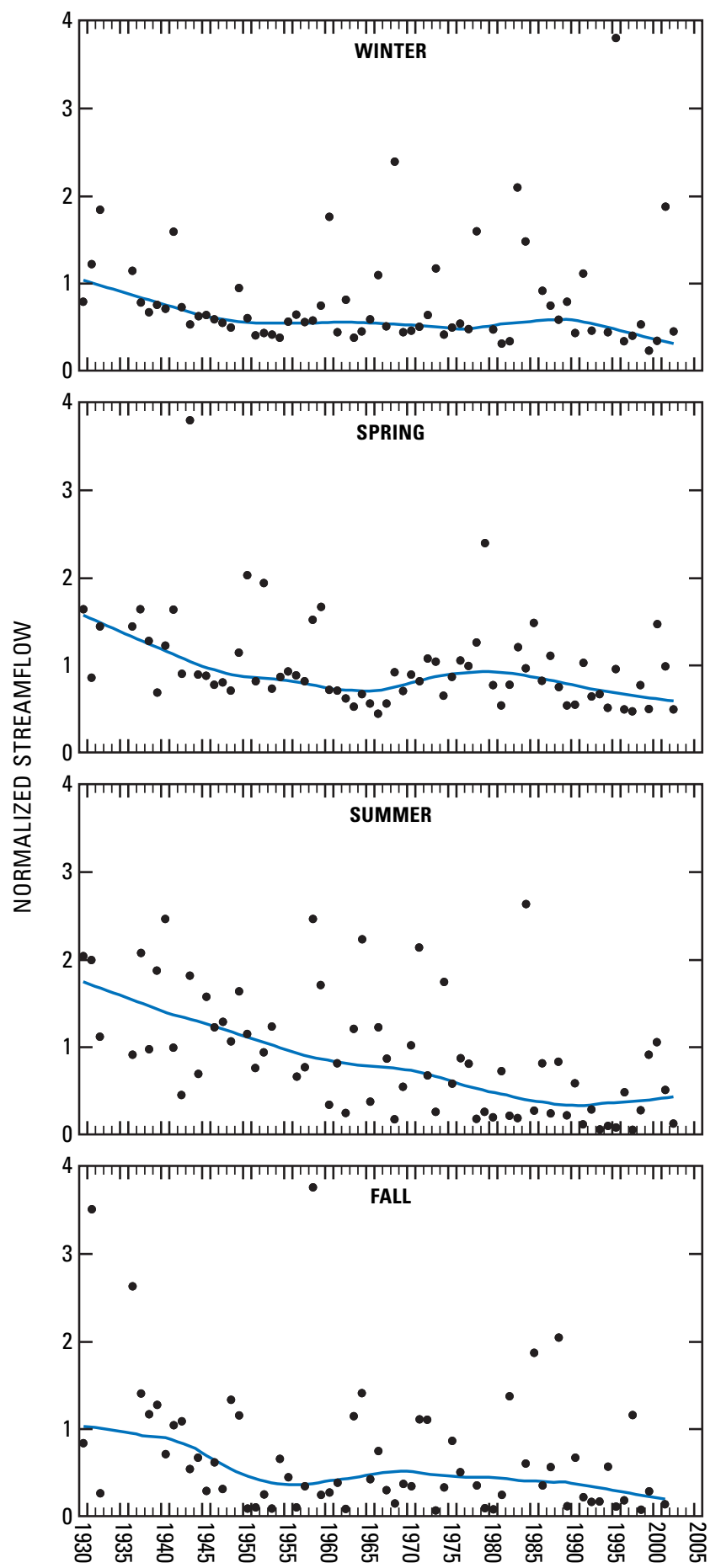

REGIONAL NORMALIZED STREAMFLOW FOR NORTHWEST AND NORTHEAST PARTS OF STUDY AREA (3 SITES)
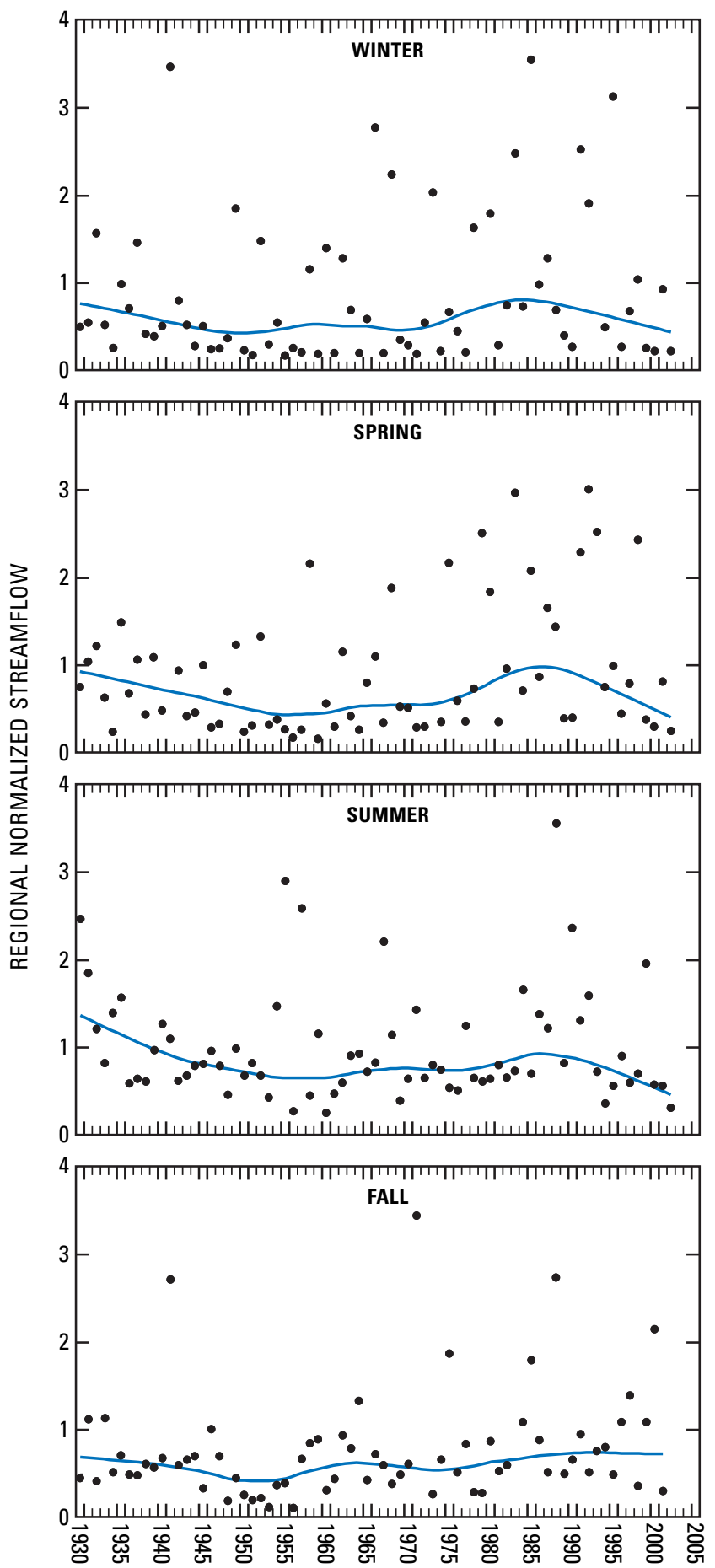

Figure 9. Trends in normalized seasonal streamflow for the San Pedro River at Charleston, Arizona, and regional normalized streamflow for the northwest and northeast parts of the study area, southeastern Arizona and southwestern New Mexico. Blue line is LOWESS fit to data. 


\section{Trends in the San Pedro River Basin}

Trends in the San Pedro River Basin were analyzed in three steps. First, the general significance and characteristics of trends in precipitation and streamflow were analyzed. Second, trends in streamflow caused by factors other than precipitation were analyzed. Finally, all the results were used for an evaluation of the causes of trends in streamflow.

\section{Hydrologic Water Budgets and Relation to Streamflow Trends}

Before results of the study of the San Pedro River Basin are presented, it is useful to describe hydrologic water budgets for the entire watershed, the ground-water system, and the streamflow of the San Pedro River. These budgets describe the relation between the sources of water (inflow) and the components of outflow. They can be used to evaluate how changes in one component can affect other components of a budget, or how a change in a component can affect streamflow trends.

The source of all water in the watershed is precipitation (table 6). Water moves through the watershed as runoff, ground-water flow and discharge, and evapotranspiration. The water can also go into storage or be removed from storage. Water can be stored for short periods of time (1) as interception by vegetation where it rapidly evaporates, or (2) on land surface where it either evaporates or infiltrates the soil. Water can also be stored for longer periods in soils or as ground water. In most watersheds, change in storage over long periods is minimal and only the three major processes are active-runoff, ground-water flow and discharge, and evapotranspiration.

Components of the predevelopment watershed budget (table 6) were estimated using information from previous studies and data from this study. The predevelopment period is prior to 1940; it is assumed that before 1940, human activities had a minimal effect on the watershed budget and long-term inflow equaled long-term outflow. Precipitation was estimated using an average value of $16.5 \mathrm{in}$. for the entire watershed (table 2), runoff was estimated using measured flow data from 1913 to 1940 for the San Pedro River at Charleston, ground-water recharge and discharge were estimated using estimates of base flow from this study and estimates of other components from Corell and others (1996), and evapotranspiration for the watershed was the residual. Notable items of the budget are that watershed evapotranspiration is more than 90 percent of precipitation and ground-water discharge is less than 2 percent of precipitation.

The effects of human activities or changes in watershed characteristics can be evaluated using the watershed budget (table 6). If precipitation stays constant over time and there is no change in storage in the watershed, any increase in an outflow component must be balanced by a decrease in another outflow component. For example, an increase in evapotranspiration must be balanced by a decrease in runoff or ground-water discharge.
Table 6. Predevelopment water budget for the watershed of the San Pedro River at Charleston, Arizona

\begin{tabular}{lcc}
\hline $\begin{array}{c}\text { Components of } \\
\text { watershed budget }\end{array}$ & $\begin{array}{c}\text { Pre-development } \\
\text { water budget } \\
\text { (acre-feet per year) }\end{array}$ & $\begin{array}{c}\text { Percent } \\
\text { of water } \\
\text { budget }\end{array}$ \\
\hline Inflow & & \\
Precipitation & $1,100,000$ & 100
\end{tabular}

Outflow

1) Runoff

49,800

2) Ground-water flow and

14,000 discharge

3) Evapotranspiration $1,036,000$ from all sources except directly from ground water $^{1}$

\section{Change in storage}

4) Interception and surface storage

$0 \quad 0$

5) Soil moisture

0

0

6) Ground water

0

${ }^{1}$ Evapotranspiration can come from (1) intercepted precipitation, (2) surface water, (3) soil moisture, (4) upland vegetation, and (5) flood plain and riparian vegetation.

The ground-water budget for the San Pedro River watershed describes the recharge (inflow) and discharge (outflow) for the ground-water system (table 7). Most recharge occurs near the mountain fronts by infiltration in mountains and subsurface inflow and percolation of runoff in stream channels that originate in the mountains. Runoff amounts from mountainous areas typically are large because of the large amount of precipitation (more than $25 \mathrm{in} . / \mathrm{yr}$ ), the steep terrain, and the low infiltration rates. About $10-20$ percent of the total recharge probably is from infiltration of runoff in ephemeralstream channels throughout the watershed. Another small percentage of the recharge, probably less than a few percent, is from direct infiltration of precipitation on upland areas and the valley floor of the watershed (Coes and Pool, 2005). Ground water discharges (1) to the San Pedro River as base flow, (2) as evapotranspiration from the shallow water table in the San Pedro River flood plain, (3) as underflow north of the watershed, or (4) by pumping from wells.

Predevelopment ground-water discharge was estimated using streamflow data from this study and information from previous studies (table 7). Base flow was estimated using monthly 3-day low flows for 1931-45. The median 3-day low flow was computed for each month (in acre-ft) and the monthly values were summed for the annual total. 
Table 7. Predevelopment water budget for groundwater system in the watershed of the San Pedro River at Charleston, Arizona

\begin{tabular}{|c|c|c|}
\hline $\begin{array}{c}\text { Components of } \\
\text { ground-water budget }\end{array}$ & $\begin{array}{l}\text { Pre-development } \\
\text { water budget } \\
\text { (acre-feet per year) }\end{array}$ & $\begin{array}{l}\text { Percent } \\
\text { of water } \\
\text { budget }\end{array}$ \\
\hline Recharge (inflow) ${ }^{1}$ & 14,000 & 100 \\
\hline 1) Mountain-front inflow & $\left({ }^{2}\right)$ & $\left({ }^{2}\right)$ \\
\hline $\begin{array}{l}\text { 2) Seepage of runoff in } \\
\text { ephemeral stream channels }\end{array}$ & $\left({ }^{2}\right)$ & $\left({ }^{2}\right)$ \\
\hline $\begin{array}{l}\text { 3) Infiltration and percolation } \\
\text { of precipitation directly into } \\
\text { ground-water system }\end{array}$ & $\left({ }^{2}\right)$ & $\left({ }^{2}\right)$ \\
\hline
\end{tabular}

\section{Discharge (outflow)}

1) Base flow of San Pedro River $^{3}$

$\begin{array}{rr}7,900 & 56 \\ 5,700 & 41 \\ 400 & 3 \\ 0 & 0\end{array}$

4) Pumping from wells (withdrawals)

\begin{tabular}{l} 
Change in storage \\
\hline${ }^{1}$ Recharge is sum of discharge components 1-3. \\
${ }^{2}$ Proportion of recharge from three sources is unknown. \\
${ }^{3}$ Estimated using monthly low-flow data from this study. \\
${ }^{4}$ From shallow water table in flood plain of San Pedro River. Estimated \\
by Corell and others (1996; fig. 7 and table 4). \\
${ }^{5}$ Estimated by Freethey (1982) and Corell and others (1996).
\end{tabular}

Several of the years of August 3-day low flow contained runoff or flow from bank storage, so the median August 3-day low flow was not representative of base flow. The median August low flow was, therefore, estimated as the average of the July and September median low-flow values. Evapotranspiration was estimated by Corell and others (1996), and underflow north of the watershed was estimated by Freethey (1982) and Corell and others (1996). Recharge was estimated as the sum of the three discharge components, under the assumption that the system was in equilibrium. This estimated ground-water budget $(14,000 \mathrm{acre}-\mathrm{ft} / \mathrm{yr})$ is smaller than previous estimates that ranged from 16,000 to 19,000 acre-ft/yr (Freethey, 1982; Vionnett and Maddock, 1992; and Corell and others, 1996). One reason why this budget is smaller is that the previous studies were for the Sierra Vista subwatershed and the San Pedro Basin in Mexico (fig. 3), which is larger than the Charleston watershed.
If recharge is assumed to be constant, any increase in an outflow component must be balanced by a decrease in storage or another outflow component (table 7). For example, an increase in ground-water pumping must be balanced by a decrease in ground-water storage, base flow, or evapotranspiration. Underflow north of the watershed also could decrease but its relative magnitude is small ( 3 percent of the budget) and it could not balance any appreciable pumping.

The budget for seasonal streamflow of the San Pedro River shows the components of inflow (gains) and components of outflow (losses) at a given point along the river (Charleston; table 8). Inflow is from runoff of precipitation, ground-water discharge, and flow from bank storage or short-term storage in the alluvial aquifer. Outflow from the stream is by flow to the alluvial aquifer (long-term), flow to bank storage or short-term storage in the alluvial aquifer, direct evapotranspiration from the water surface, or transpiration from riparian vegetation adjacent to the stream channel. The streamflow at Charleston is the net addition and subtraction of all these components acting on streamflow upstream from Charleston.

It is clear that a decrease in a source of inflow to the river, such as runoff or ground-water discharge, would cause a decrease in streamflow. An increase in a component of outflow, however, could also cause a decrease in streamflow.

Table 8. Water budget for seasonal streamflow of the San Pedro River at Charleston, Arizona

\section{Components of inflow and outflow}

Inflow to stream (gains)

1) Runoff of precipitation

A) Overland flow and tributary streamflow from upland areas

B) Shallow subsurface stormflow from upland areas

C) Overland flow from saturated soils in San Pedro River flood plain

2) Ground-water discharge

A) Regional aquifer

B) Local alluvial aquifer (long-term sustained discharge)

3) Flow from bank storage or short-term storage in alluvial aquifer

\section{Outflow from stream (losses)}

1) Flow to alluvial aquifer (long-term sustained flow)

2) Direct evaporation from water surface

3) Transpiration from riparian vegetation adjacent to the stream channel

4) Flow to bank storage or short-term storage in alluvial aquifer 


\section{Trends in Precipitation and Streamflow}

Monotonic trends for the following characteristics of monthly and seasonal precipitation at Tombstone were evaluated: total volume, intensity, frequency, and volume per storm. Most characteristics of precipitation and most months and seasons had no significant trends for 1913-2002 (fig. 10 and table 9). Precipitation in July and summer were the only month and (or) season with a significant decreasing trend. The monotonic trends shown in table 9 are for the entire record of precipitation at Tombstone. To determine if some shorter periods of time within 1913-2002 had significant trends in total precipitation, trend tests were made on early and late subsets of that record with breakpoints at 1950, 1960, and 1970 (table 10). Only a few of the monthly or seasonal values of precipitation had significant trends. November precipitation had significant decreasing trends for 1913-50 and 1913-60, summer precipitation had a significant decreasing trend for 1951-2002, and annual precipitation had a nearly significant $(p$-value $=0.061)$ decreasing trend for 1913-70. The time periods of no trends and decreasing trends for summer and annual precipitation can be seen in figure 10 .

Changes in seasonal total streamflow and low flow for the San Pedro River at Charleston were calculated from the predevelopment period (prior to 1940) to 1991-2002. Annual total flow decreased by 62 percent from 57,700 acre-ft/yr in the predevelopment period to 22,000 acre-ft/yr in 1991-2002 (table 11). Changes in summer flows dominated the changes in annual flows; 70 percent of the decrease in annual flow was from the decrease in summer flow. Annual low flow decreased by 46 percent from 7,900 acre-ft/yr to 4,300 acre-ft/yr (table 11). This low flow is roughly analogous to base flow, which has been evaluated and discussed in many previous studies (Corell and others, 1996; Pool and Coes, 1999; and Rojo and others, 1999). About 60 percent of the decrease in annual low flow was during the fall and early winter (September-January).

Trends in seasonal total streamflow for several time periods were determined for the San Pedro River at Palominas, Charleston, and Redington (fig. 2 and table 12). Differences or similarities in trends at the three different sites on the river can potentially provide some insight on the causes of streamflow trends. The drainage areas for the three sites are $737 \mathrm{mi}^{2}$ at Palominas, 1,234 $\mathrm{mi}^{2}$ at Charleston, and $2,927 \mathrm{mi}^{2}$ at Redington. The vegetation, land-surface relief, and elevations of the three watersheds are similar; however, human activities are different. Ground-water pumping in the Palominas watershed has been primarily for a mine in Mexico, and a small amount has been for agriculture and domestic uses. In the watershed between Palominas and Charleston, water is pumped for public supply, domestic use, and agriculture. In the watershed between Charleston and Redington, water is pumped for a military base (Fort Huachuca) and for agriculture.
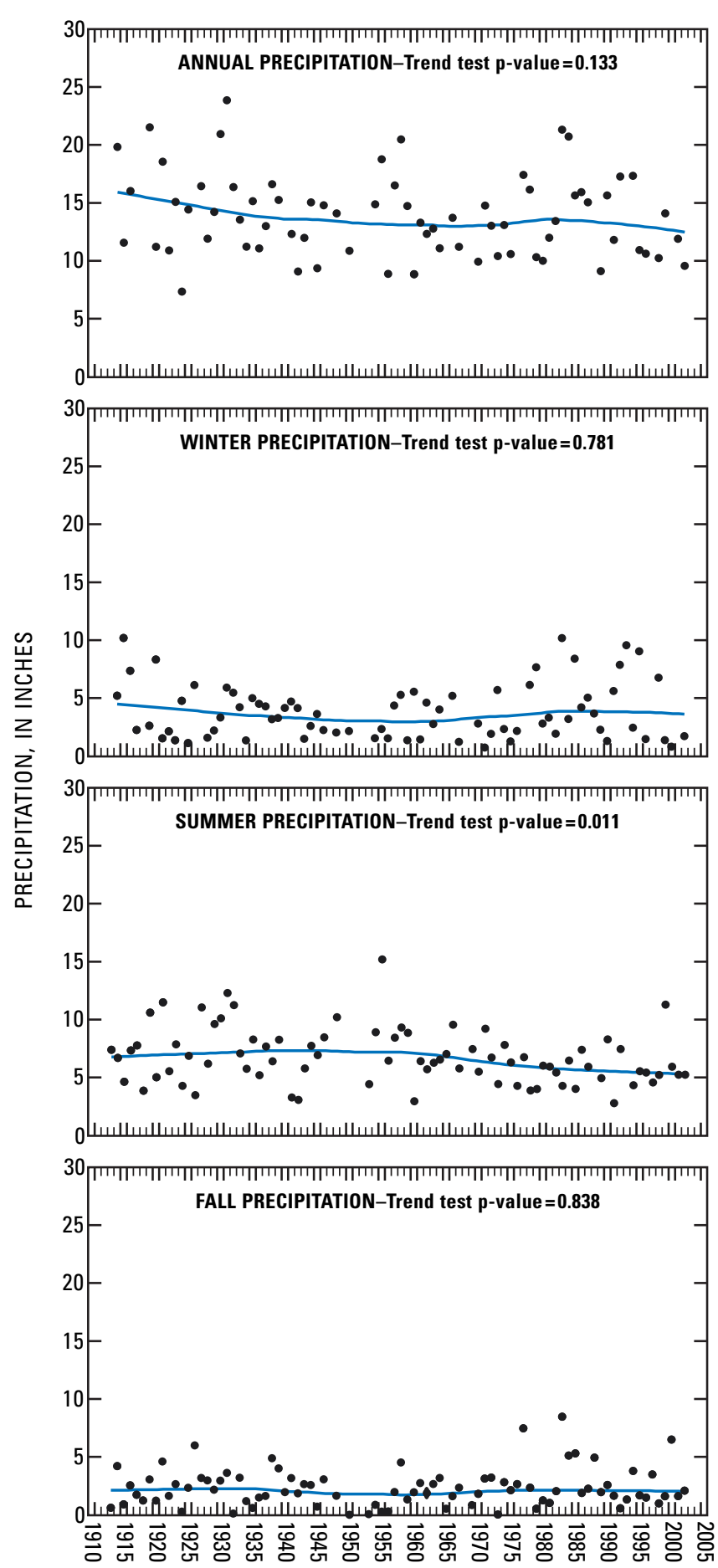

Figure 10. Trends in annual and seasonal precipitation at Tombstone, Arizona. Blue line is LOWESS fit to data. 
Table 9. Trends in monthly, seasonal, and annual precipitation at Tombstone, Arizona, 1913-2002

[>, greater than; <, less than]

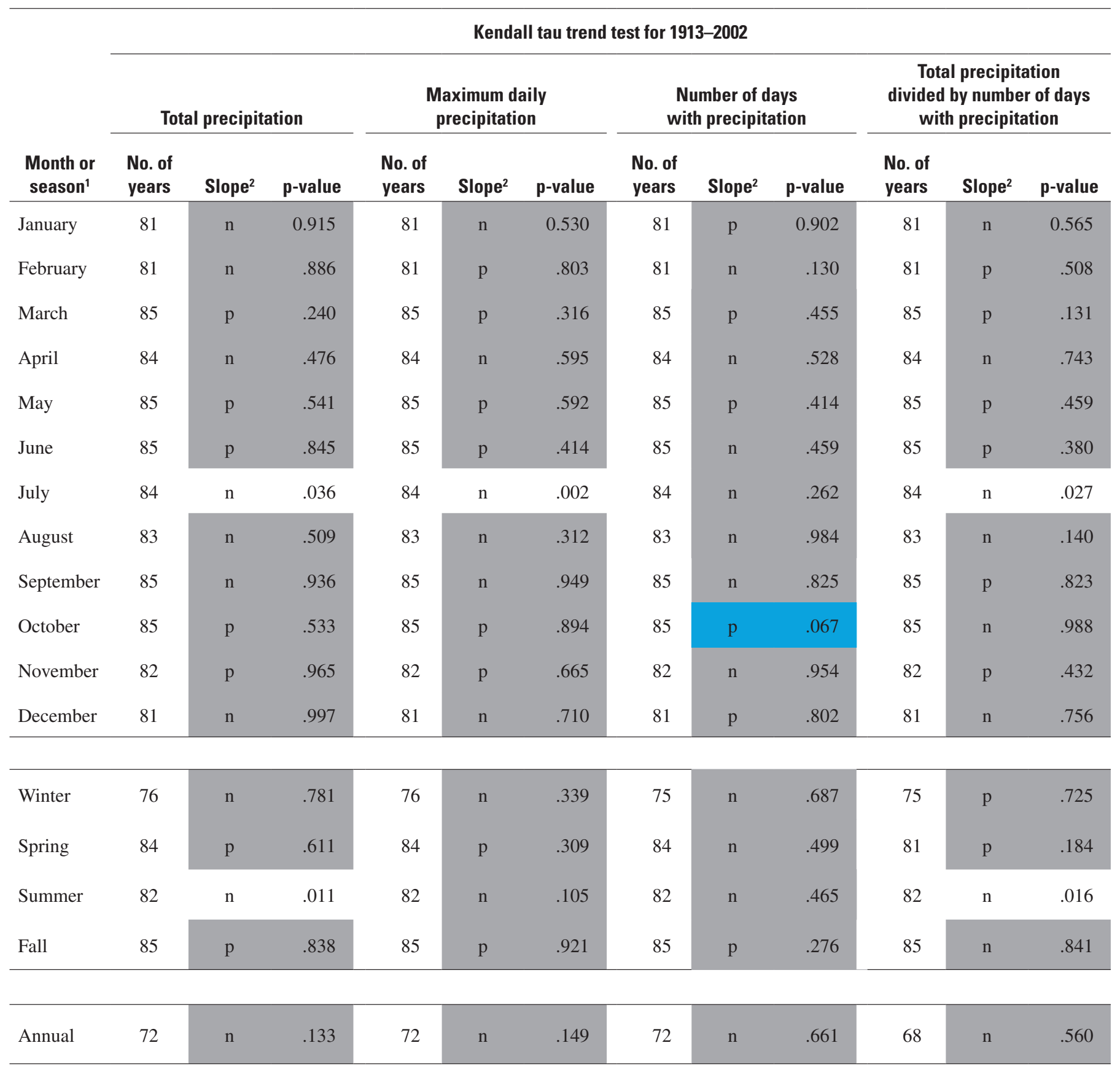

${ }^{1}$ Winter is November-March, spring is April-June, summer is July-August, and fall is September-October.

${ }^{2}$ Slope of trend: $n$ is negative and $p$ is positive.

\begin{tabular}{|c|l|l|}
\cline { 3 - 3 } \multicolumn{2}{c|}{} & $\mathrm{p}$-value \\
\hline $\mathrm{n}$ or $\mathrm{p}$ & no significant trend & $>0.10$ \\
\hline $\mathrm{n}$ & significant negative trend & $<0.05$ \\
\hline $\mathrm{p}$ & nearly significant positive trend & $0.05-0.10$ \\
\hline
\end{tabular}


Table 10. Trends in monthly, seasonal, and annual total precipitation at Tombstone, Arizona, for selected time periods

[Slp, slope; >, greater than; <, less than]

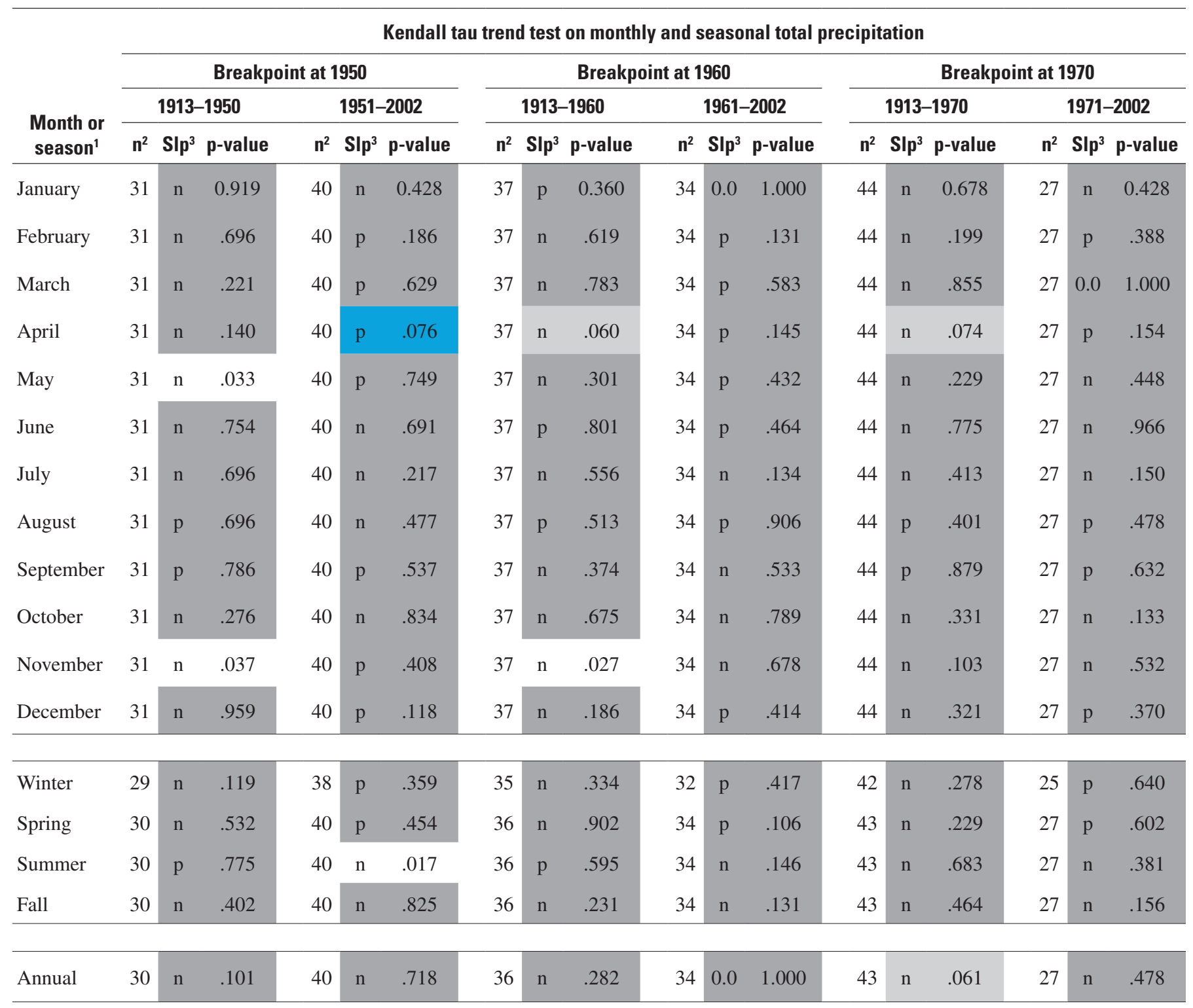

${ }^{1}$ Winter is November-March, spring is April-June, summer is July-August, and fall is September-October.

${ }^{2}$ Number of years analyzed.

${ }^{3}$ Slope of trend: $\mathrm{n}$ is negative and $\mathrm{p}$ is positive.

\begin{tabular}{|c|l|l|}
\cline { 3 - 3 } \multicolumn{2}{c|}{} & $\mathrm{p}$-value \\
\hline $\mathrm{n}$ or $\mathrm{p}$ & no significant trend & $>0.10$ \\
\hline $\mathrm{n}$ & nearly significant negative trend & $0.05-0.10$ \\
\hline $\mathrm{n}$ & significant negative trend & $<0.05$ \\
\hline $\mathrm{p}$ & nearly significant positive trend & $0.05-0.10$ \\
\hline
\end{tabular}


Table 11. Changes in seasonal and annual total streamflow and low flow from the predevelopment period to 1991-2002, San Pedro River at Charleston, Arizona

\begin{tabular}{|c|c|c|c|c|c|c|}
\hline \multirow[b]{2}{*}{ Flow' ${ }^{1}$} & \multirow[b]{2}{*}{ Season ${ }^{2}$} & \multicolumn{2}{|c|}{$\begin{array}{l}\text { Streamflow for time period }{ }^{3} \\
\text { (acre-feet per year) }\end{array}$} & \multicolumn{2}{|c|}{ Change in streamflow } & \multirow{2}{*}{$\begin{array}{l}\text { Percent } \\
\text { of annual } \\
\text { change }\end{array}$} \\
\hline & & Predevelopment ${ }^{4}$ & 1991-2002 & $\begin{array}{c}\text { Total } \\
\text { (acre-feet per year) }\end{array}$ & Percent & \\
\hline \multirow[t]{7}{*}{ Total flow } & Late winter & 3,100 & 3,100 & 0 & 0 & 0 \\
\hline & Spring & 2,500 & 1,300 & $-1,200$ & -48 & 3 \\
\hline & Summer & 31,400 & 6,300 & $-25,100$ & -80 & 70 \\
\hline & Fall & 11,800 & 4,800 & $-7,000$ & -59 & 20 \\
\hline & Early winter & 8,900 & 6,500 & $-2,400$ & -27 & 7 \\
\hline & Annual & 57,700 & 22,000 & $-35,700$ & -62 & 100 \\
\hline & (cubic-feet per second) & $(79.7)$ & $(30.4)$ & $(-49.3)$ & & \\
\hline \multirow[t]{7}{*}{ Low flow } & Late winter & 1,600 & 1,400 & -200 & -13 & 5 \\
\hline & Spring & 1,200 & 700 & -500 & -42 & 14 \\
\hline & Summer & 900 & 300 & -600 & -67 & 17 \\
\hline & Fall & 1,500 & 400 & $-1,100$ & -73 & 31 \\
\hline & Early winter & 2,700 & 1,500 & $-1,200$ & -44 & 33 \\
\hline & Annual & 7,900 & 4,300 & $-3,600$ & -46 & 100 \\
\hline & (cubic-feet per second) & $(10.9)$ & (5.9) & $(-5.0)$ & & \\
\hline
\end{tabular}

${ }^{1}$ Total flow is calculated from monthly average flows and low flow is calculated from monthly 3-day low flows.

${ }^{2}$ Late winter is February-March, spring is April-June, summer is July-August, fall is September-October, and early winter is November-January.

${ }^{3}$ Seasonal total streamflow is the seasonal average streamflow for the time period. Seasonal low flow was calculated differently so it can be a surrogate for base flow of the stream. First the median low flow was computed for each month for the time period. Then the seasonal low flow was computed as the average of the median monthly low flows in each season.

${ }^{4}$ Predevelopment period; total flow was 1913-40 and low flow was 1931-45. 
Table 12. Trends in seasonal total streamflow of the San Pedro River at Palominas, Charleston, and Redington, Arizona, for selected time periods

$[<$, less than; ---, no data]

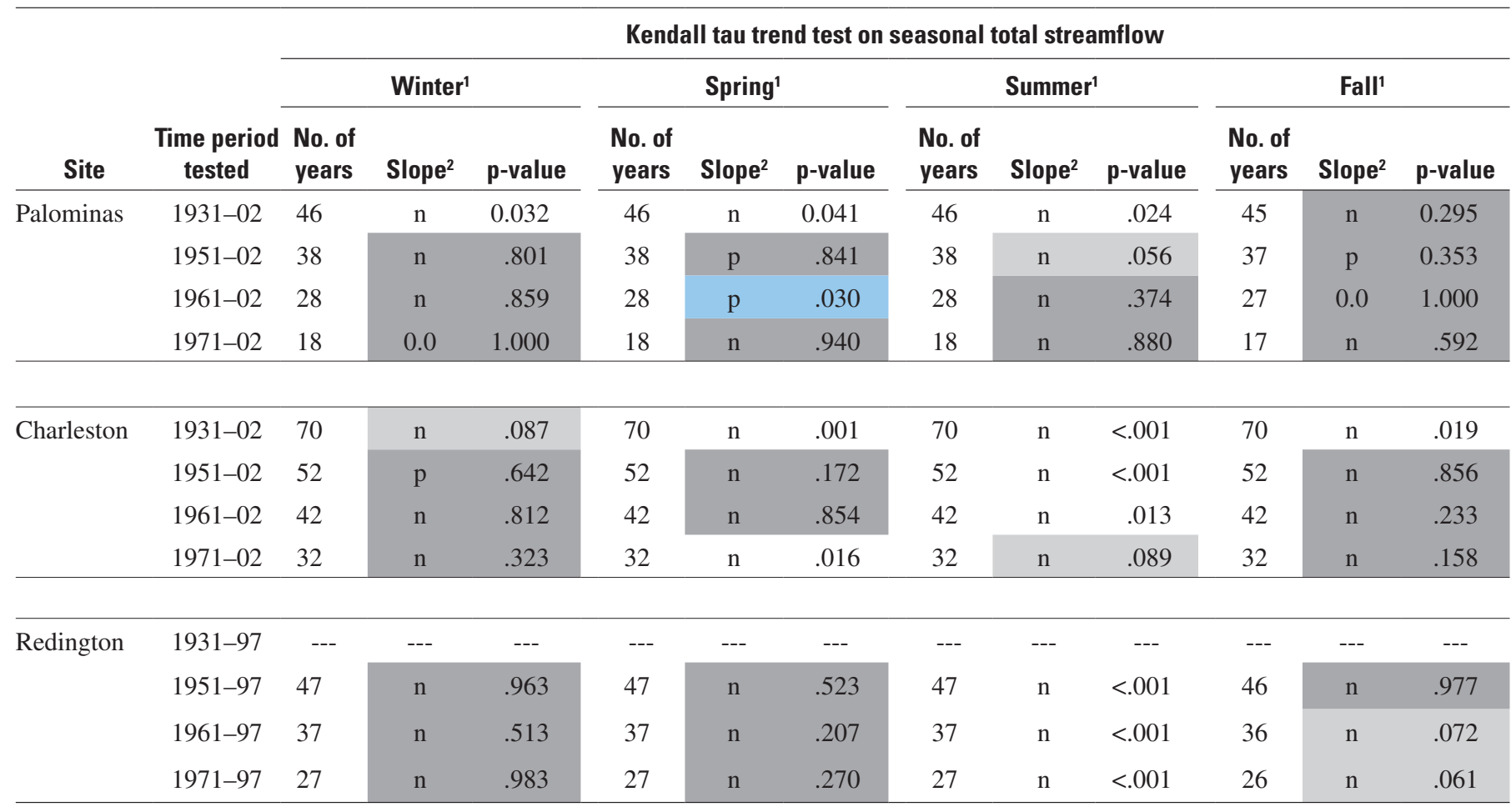

${ }^{1}$ Winter is November-March, spring is April-June, summer is July-August, and fall is September-October.

${ }^{2}$ Slope of trend: $\mathrm{n}$ is negative and $\mathrm{p}$ is positive.

\begin{tabular}{|c|l|l|}
\cline { 3 - 3 } \multicolumn{2}{c|}{} & p-value \\
\hline $\mathrm{n}$ or $\mathrm{p}$ & no significant trend & $>0.10$ \\
\hline $\mathrm{n}$ & nearly significant negative trend & $0.05-0.10$ \\
\hline $\mathrm{n}$ & significant negative trend & $<0.05$ \\
\hline $\mathrm{p}$ & significant positive trend & $<0.05$ \\
\hline
\end{tabular}

Seasonal trends in total streamflow at the three sites were similar (table 12). Summer flows at Charleston and Redington significantly or nearly significantly decreased for all time periods, and summer flows at Palominas significantly or nearly significantly decreased from 1931 and 1951 to 2002 . The nonsignificant trends in summer flows at Palominas from 1961 and 1971 to 2002 may be related to the large gap in the flow record from 1982 to 1995 . Trends in winter flows at the three sites were similar in that there were no significant trends at all three sites from 1951, 1961, and 1971 to 2002. Spring and fall flows had mixed trends, but generally were similar at the three sites. These results indicate that the same factor or factors likely were influential in the streamflow trends at all three sites.

Step trends or shifts in seasonal values of total and maximum precipitation and streamflow were evaluated for six time periods during 1913-2002. The advantage of this approach was that trends in both the central tendency and the variability could be evaluated and short-term trends within 1913-2002 could be evaluated. The central tendency was represented by the median, and the variability was represented by the IQR.

Median values of precipitation had no large step trends (fig. 11). The variability of precipitation had some larger step changes over time. The interannual variability of winter total precipitation appears to have increased after about 1976. The interannual variability of maximum daily precipitation changed appreciably over time for all three seasons; winter variability had a step change to higher values after 1976, summer variability changed frequently with the highest value in 1943-60, and fall variability had a general decreasing trend over time. 

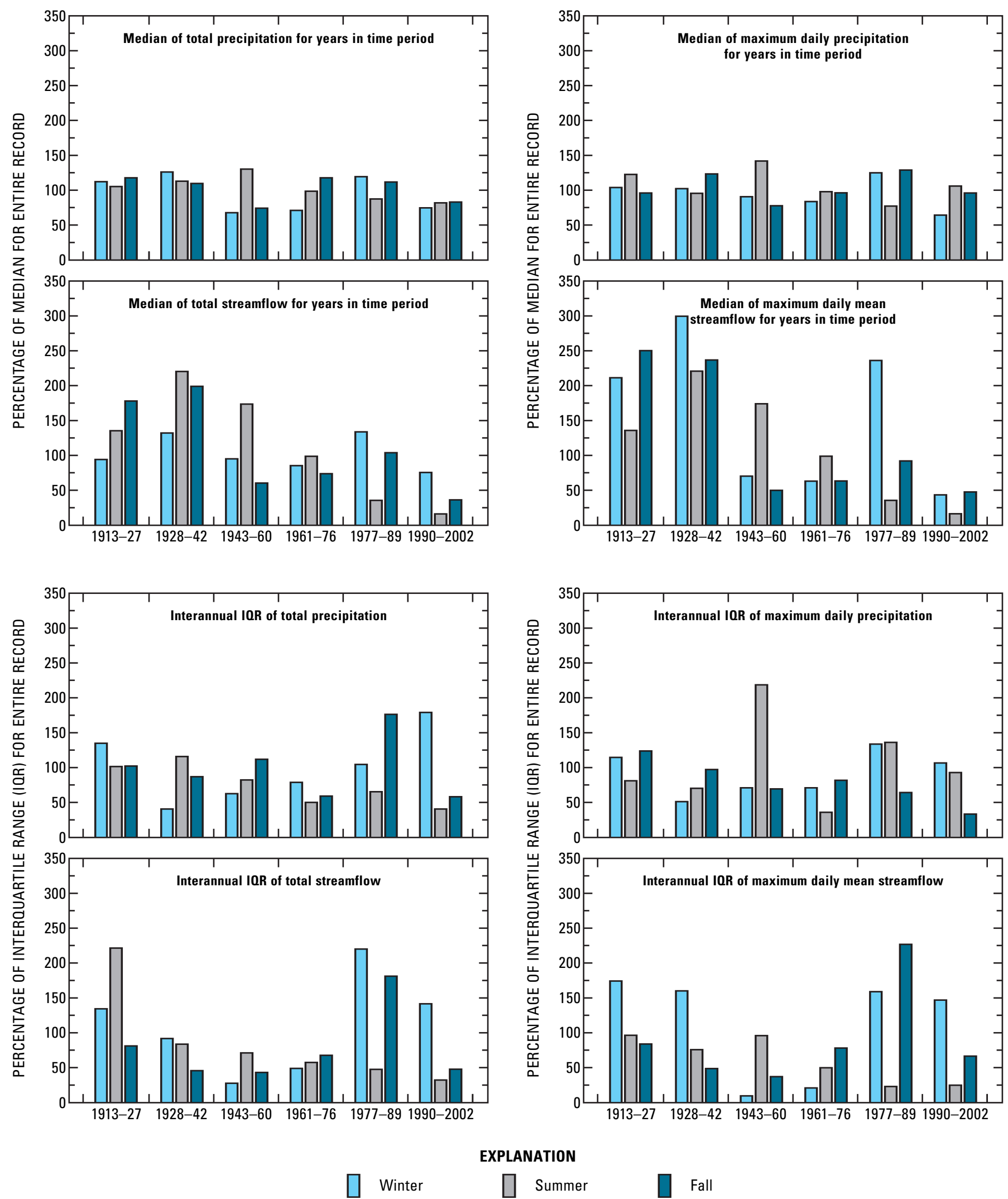

Figure 11. Step trends in central tendency and variability of precipitation at Tombstone, Arizona, and streamflow of the San Pedro River at Charleston, Arizona. IQR is the interquartile range; 75th percentile minus the 25th percentile, 
Streamflow had larger changes over time in median values and variability than did precipitation (fig. 11). For median total and maximum streamflows, there is a step change at about 1943; before 1943 all seasonal flows were high, and after 1942 all seasonal flows were generally low. The behavior of the median seasonal flows after 1942 is different; summer median flows decreased continuously, and fall and winter median flows were mostly steady except for higher values during 1977-89.

The interannual variability of seasonal streamflows also had patterns. The variability of winter maximum flow had two distinct step changes; the variability was high during 1913-42, low during 1943-76, and high again during 1977-2002. Variability of summer total flow decreased monotonically during the entire record, and variability of summer maximum flow had a step change from high to low values at 1960 . Variability of fall total and maximum flow was generally similar for the entire record except for a high period during 1977-89.

\section{Trends in Streamflow Caused by Factors Other than Precipitation}

Two methods were used to evaluate trends in streamflow caused by factors other than precipitation. Both methods used regression analysis to remove or account for the variation in streamflow caused by variation in precipitation. Once the variation was removed or accounted for, the remaining variation in streamflow was tested for trends over time. One method tested for monotonic trends and the other method tested for step trends.
The two methods were applied to monthly values of total flow, low flow, and storm runoff. Total flow (average flow) provides information about the total quantity of flow in the river each month. Low flow (3-day low flow) is a rough approximation of base flow- the flow sustained by groundwater discharge. Storm runoff (maximum daily mean flow) is the quick response of the watershed to rainfall. Preliminary analyses of the monthly flow data showed that low flow is about 80 percent of total flow in the winter and about 10 percent of total flow in the summer (table 13). Summer total flow is, therefore, mostly runoff of precipitation. The storm runoff analyzed in this study was the maximum daily mean flow for the month; this flow component represents a 1-day response to rainfall. Storm runoff (in $\mathrm{ft}^{3} / \mathrm{s}$ ) was about five times greater than monthly total flow (in $\mathrm{ft}^{3} / \mathrm{s}$ ) in the winter and eight times greater than monthly total flow in the other seasons (table 13).

\section{Monotonic Trends}

LOWESS multiple-variable regression analyses and Kendall tau statistical tests were used to determine monotonic trends in monthly streamflow caused by factors other than precipitation. Before the LOWESS analyses were performed, all variables (precipitation and streamflow) were $\log$ transformed to improve the accuracy of the LOWESS equations and to decrease the heteroscedasticity of the data (variance of streamflow increases as values of precipitation increase). The analyses were performed on total flow (average flow), low flow (3-day low flow), and storm runoff (maximum daily mean flow).

Table 13. Seasonal relations between low flow, total flow, and maximum daily storm runoff, San Pedro River at Charleston, Arizona, 1931-2002

[---, no data]

\begin{tabular}{|c|c|c|c|}
\hline \multirow[b]{2}{*}{ Season ${ }^{1}$} & \multicolumn{2}{|c|}{ Percentage of total streamflow ${ }^{2}$} & \multirow{2}{*}{$\begin{array}{l}\text { Ratio of maximum daily storm } \\
\text { runoff to total monthly flow }\end{array}$} \\
\hline & Low flow ${ }^{3}$ & Runoff + flow from bank storage ${ }^{4}$ & \\
\hline Winter & 82 & 18 & 4.8 \\
\hline Early spring & 72 & 28 & --- \\
\hline Late spring & 55 & 45 & 9.7 \\
\hline Summer & 8 & 92 & 7.7 \\
\hline Early fall & 22 & 78 & 7.0 \\
\hline Late fall & 67 & 33 & 6.7 \\
\hline
\end{tabular}

${ }^{1}$ Season: winter is November-March, early spring is April-May, late spring is June, summer is July-August, early fall is September, and late fall is October.

${ }^{2}$ The ratio of monthly low flow, in cubic feet per second, to total flow, in cubic feet per second, was computed for each month during 1931-2002. The median value of the ratios was then computed for each month. The seasonal percentage is the average of the median ratios for each month in the season.

${ }^{3}$ Low flow is the 3-day low flow.

${ }^{4}$ Runoff + flow from bank storage is the difference between total flow and low flow.

${ }^{5}$ The ratio of maximum daily mean flow, in cubic feet per second, to average flow, in cubic feet per second, was computed for each month during 19312002. The median value of the ratios was then computed for each month. The seasonal ratio is the average of the median ratios for each month in the season. 
The final LOWESS equations had several combinations of monthly precipitation for the explanatory variables. The final equations were selected on the basis of whether they were physically reasonable and various measures of statistical fit including highest $R^{2}$ value; lowest standard error of estimate; lack of any extreme outliers; and best overall distribution of residuals compared to a normal distribution, fitted values, and explanatory variables.

A simple illustration of a multiple-variable LOWESS fit to a streamflow-precipitation relation is not possible, therefore, some examples are shown to illustrate how singlevariable LOWESS equations fit the nonlinear relation between monthly precipitation and total streamflow (fig. 12). LOWESS analysis is especially needed for the February, September, and November flows, and it also is a better fit than a least-squares linear fit to the July flows.

The $R^{2}$ values for the multiple-variable LOWESS regression equations for monthly total streamflow ranged from 0.50 to 0.81 (table 14). Thus, precipitation explained between 50 and 81 percent of the variation in monthly streamflows.
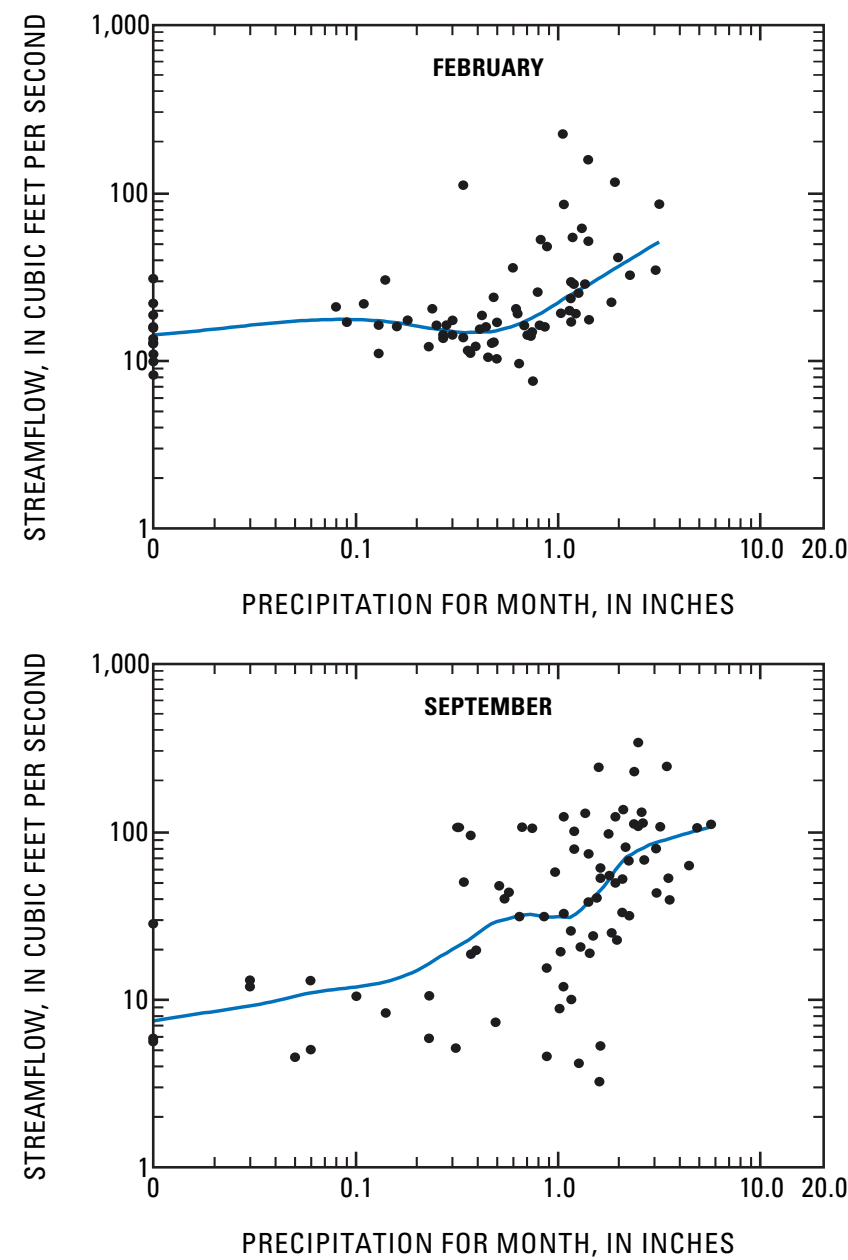

The number of months of precipitation in the equations ranged from three to four, and the equations generally used precipitation for the same month as streamflow and precipitation for months immediately prior to the streamflow (table 15). During June-January, precipitation for the same month as streamflow was the best single month for explaining total streamflow. During February-May, the best single month of precipitation varied from 1 to 4 months prior to streamflow.

Precipitation for the same month as streamflow is a measure of the amount of direct runoff that contributes to streamflow. Precipitation during months prior to a monthly streamflow affects the streamflow in two ways: (1) it builds up storage in watershed soils that results in decreased infiltration of precipitation and increased runoff, and (2) it increases runoff and streamflow in preceding months that results in increased bank storage and storage in the alluvial aquifer. This increased storage increases flow by decreasing the loss of the current flow into storage or by releasing water from storage and contributing to the current flow.
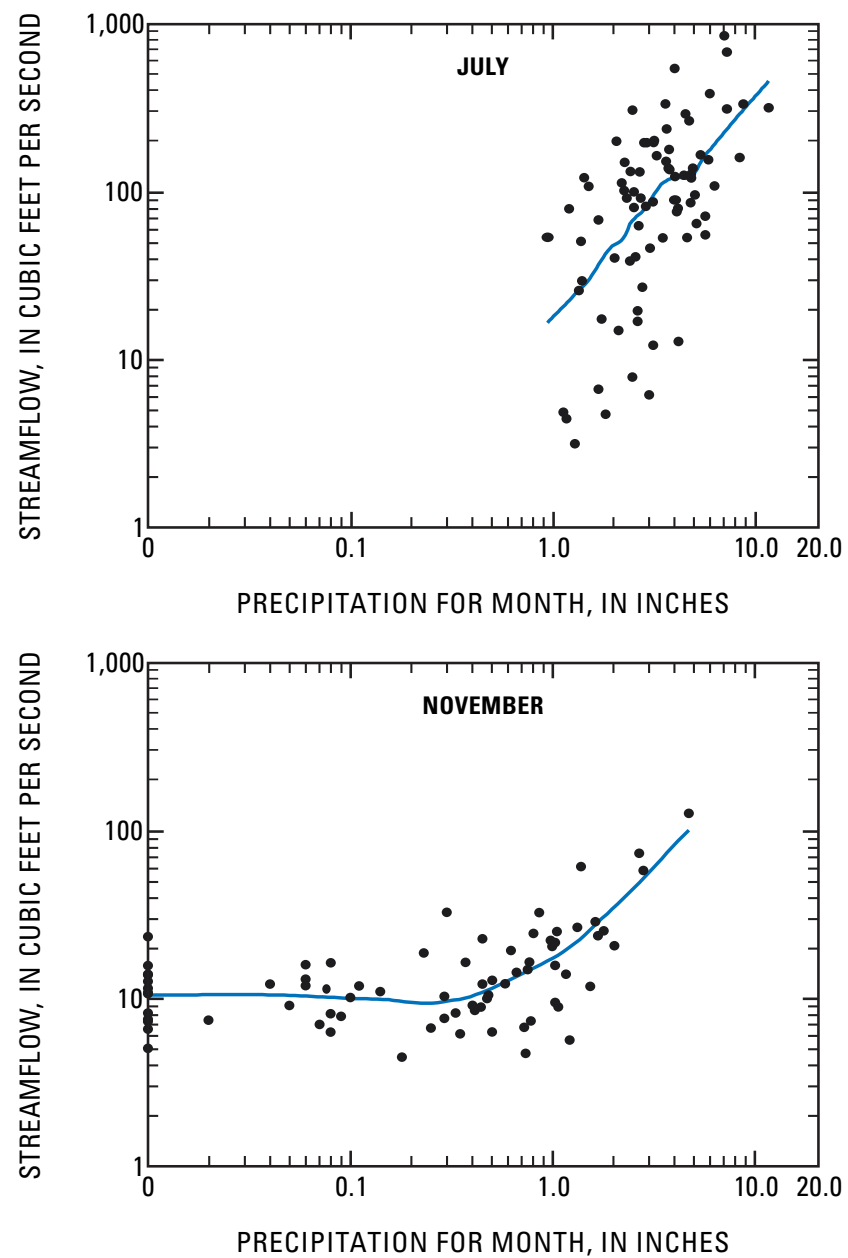

Figure 12. LOWESS fits between precipitation at Tombstone, Arizona, and selected monthly total streamflows of the San Pedro River at Charleston, Arizona. Blue line is LOWESS fit to data. 
Table 14. Results of LOWESS regression analyses between monthly precipitation at Tombstone, Arizona, and monthly total streamflow for the San Pedro River at Charleston, Arizona; and between precipitation at Tombstone and time, 1913-2002

$\left[R^{2}\right.$, coefficient of multiple determination]

\begin{tabular}{|c|c|c|c|c|c|c|c|c|}
\hline \multirow[b]{4}{*}{ Month } & \multirow[b]{4}{*}{$\begin{array}{c}\text { Number } \\
\text { of years } \\
\text { analyzed }\end{array}$} & \multicolumn{7}{|c|}{ LOWESS regression models ${ }^{2}$} \\
\hline & & \multirow[b]{2}{*}{ Explanatory variables } & \multicolumn{6}{|c|}{ Response variable } \\
\hline & & & \multicolumn{3}{|c|}{$\begin{array}{c}\text { Total streamflow } \\
\text { (cubic feet per second) }\end{array}$} & \multicolumn{3}{|c|}{$\begin{array}{c}\text { Time } \\
\text { (years) }\end{array}$} \\
\hline & & $\begin{array}{l}\text { Monthly precipitation } \\
\text { (inches) }\end{array}$ & $R^{2}$ & $\begin{array}{l}\text { Standard error } \\
\text { (log units) }\end{array}$ & $\operatorname{Span}^{3}$ & $R^{2}$ & $\begin{array}{l}\text { Standard error } \\
\text { (years) }\end{array}$ & Span \\
\hline January & 72 & Oct., Nov., Dec., and Jan. & 0.81 & 0.260 & 0.75 & 0.51 & 28.14 & 0.75 \\
\hline February & 72 & Dec., Jan., and Feb. & .80 & .182 & .60 & .29 & 28.70 & .75 \\
\hline March & 76 & Jan., Feb., and Mar. & .66 & .187 & .75 & .51 & 26.69 & .50 \\
\hline April & 76 & Jan., Feb., and Mar. & .50 & .178 & .75 & .51 & 26.69 & .50 \\
\hline May & 76 & Jan., Feb., and Mar. & .52 & .182 & .75 & .51 & 26.69 & .50 \\
\hline June & 73 & Dec., Jan., Mar., and June & .73 & .346 & .75 & .69 & 30.01 & .50 \\
\hline July & 76 & Jan., May, June, and July & .70 & .433 & .75 & .64 & 27.00 & .60 \\
\hline August & 74 & Feb., July, and Aug. & .64 & .349 & .75 & .39 & 27.35 & .60 \\
\hline September & 79 & May, Aug., and Sept. & .62 & .404 & .75 & .23 & 28.64 & .75 \\
\hline October & 79 & May, Sept., and Oct. & .77 & .340 & .60 & .27 & 30.60 & .60 \\
\hline November & 77 & June., Oct., and Nov. & .74 & .196 & .60 & .26 & 27.30 & .75 \\
\hline December & 76 & Oct., Nov., and Dec. & .78 & .267 & .50 & .38 & 26.76 & .60 \\
\hline
\end{tabular}

${ }^{1}$ Time period for analyses was 1913-2002.

${ }^{2}$ LOWESS regression models:

Response variable, total streamflow: $\log Q_{\mathrm{n}}=\log P_{1}+\log P_{2}+\log P_{\mathrm{n}}$ where $Q_{\mathrm{n}}$ is average streamflow for month $\mathrm{n}$, in cubic feet per second, and $P_{\mathrm{n}}$ is precipitation for month $\mathrm{n}$, in inches.

Response variable, time: $T_{\mathrm{n}}=\log P_{1}+\log P_{2}+\log P_{\mathrm{n}}$ where $T_{\mathrm{n}}$ is time for month $\mathrm{n}$, in years, and $P_{\mathrm{n}}$ is precipitation for month $\mathrm{n}$, in inches.

${ }^{3}$ Span is a parameter that controls the window width and smoothness of the fitted LOWESS model. As the span is increased, the window width is increased and more points influence the magnitude of the fitted values. Thus, a larger span will have a smoother fitted model than a smaller span. 
Table 15. Explanatory variables for LOWESS regression equations between monthly precipitation at Tombstone, Arizona, and monthly streamflow for the San Pedro River at Charleston, Arizona

$\left[R^{2}\right.$, coefficient of multiple determination $]$

\section{A. Total flow (monthly average flow)}

\begin{tabular}{|c|c|c|c|c|c|c|c|c|c|c|c|}
\hline \multicolumn{9}{|c|}{ Explanatory variables } & \multirow{4}{*}{$\begin{array}{l}\text { Response variable } \\
\text { Average flow in } \\
\text { indicated month }\end{array}$} & \multicolumn{2}{|c|}{ LOWESS $R^{2}$ value } \\
\hline \multicolumn{9}{|c|}{ Precipitation } & & \multirow{3}{*}{$\begin{array}{l}\text { Month with best } \\
R^{2} \text { value }^{1}\end{array}$} & \multirow[b]{3}{*}{ All months } \\
\hline \multicolumn{8}{|c|}{ Previous months } & \multirow{2}{*}{$\begin{array}{l}\text { Current } \\
\text { month }\end{array}$} & & & \\
\hline 8 & 7 & 6 & 5 & 4 & 3 & 2 & 1 & & & & \\
\hline & & & & & Oct & Nov & Dec & Jan & January & 0.42 & 0.81 \\
\hline & & & & & & Dec & Jan & Feb & February & .41 & .80 \\
\hline & & & & & & Jan & Feb & Mar & March & .29 & .66 \\
\hline & & & & & Jan & Feb & Mar & & April & .28 & .50 \\
\hline & & & & Jan & Feb & Mar & & & May & .21 & .52 \\
\hline & & Dec & Jan & & Mar & & & June & June & .28 & .73 \\
\hline & & Jan & & & & May & June & July & July & .33 & .70 \\
\hline & & Feb & & & & & July & Aug & August & .39 & .64 \\
\hline & & & & May & & & Aug & Sept & September & .41 & .62 \\
\hline & & & May & & & & Sept & Oct & October & .49 & .77 \\
\hline & & & June & & & & Oct & Nov & November & .47 & .74 \\
\hline & & & & & & Oct & Nov & Dec & December & .53 & .78 \\
\hline
\end{tabular}

\section{B. Low flow (monthly 3-day low flow)}

\begin{tabular}{|c|c|c|c|c|c|c|c|c|c|c|c|}
\hline \multicolumn{9}{|c|}{ Explanatory variables } & \multirow{4}{*}{$\begin{array}{c}\text { Response variable } \\
\text { Low flow in } \\
\text { indlcated month }\end{array}$} & \multicolumn{2}{|c|}{ LOWESS $R^{2}$ value } \\
\hline \multicolumn{9}{|c|}{ Precipitation } & & \multirow{3}{*}{$\begin{array}{l}\text { Month with best } \\
R^{2} \text { value }^{1}\end{array}$} & \multirow[b]{3}{*}{ All months } \\
\hline \multicolumn{8}{|c|}{ Previous months } & \multirow{2}{*}{$\begin{array}{l}\text { Current } \\
\text { month }\end{array}$} & & & \\
\hline \multirow[t]{8}{*}{8} & 7 & 6 & 5 & 4 & 3 & 2 & 1 & & & & \\
\hline & & & & & Oct & Nov & Dec & Jan & January & 0.28 & 0.80 \\
\hline & & & & & Nov & Dec & Jan & & February & .46 & .82 \\
\hline & & & & & & Jan & Feb & Mar & March & .33 & .58 \\
\hline & & & & & Jan & Feb & Mar & & April & .25 & .60 \\
\hline & & Nov & Dec & Jan & & Mar & & & May & .14 & .75 \\
\hline & & Dec & Jan & & & & & June & June & .21 & .57 \\
\hline & & & & & April & May & June & July & July & .14 & .81 \\
\hline Dec & & & & & & & July & Aug & August & .18 & .67 \\
\hline \multirow[t]{4}{*}{ Jan } & & & & & & & Aug & Sept & September & .38 & .60 \\
\hline & & & May & & & Aug & Sept & & October & .32 & .66 \\
\hline & & & & & Aug & & Oct & & November & .50 & .65 \\
\hline & & & & Aug & & Oct & Nov & & December & .37 & .59 \\
\hline
\end{tabular}


The $R^{2}$ values for the multiple-variable LOWESS regression equations for monthly low flow ranged from 0.57 to 0.82 (table 16). The number of months of precipitation in the equations ranged from two to four. The combination of months in the low-flow equations was generally different from the combination of months used in the total-flow equations (table 15). Precipitation for the same month as low flow was used less often, and months of precipitation prior to the flow were much more important. This makes physical sense because low flows should be less influenced by precipitation and direct runoff for the same month and more influenced by the amount of storage in the stream bank and alluvial aquifer. Precipitation and associated total flows can build up bank storage over many months, and the storage can be released to low flows several months after the precipitation. Low flows during February-June were mostly influenced by precipitation in the previous winter. Low flows during September-December were mostly influenced by precipitation in the previous summer or fall.

The multiple-variable LOWESS regression equations for storm runoff were successful for some months and not successful for other months (table 17). Most months of the year could not be analyzed because of insufficient data; only June, July, August, September, and October had enough data for analysis. The equations were successful for July, September, and October; $R^{2}$ values ranged from 0.57 to 0.84 . The equation for June had an $R^{2}$ of 0.32 , and the equation for August had an $R^{2}$ of 0.35 ; these equations are considered to be too inaccurate for use in the next step of trend analysis. The periods of precipitation that were most successful in explaining maximum daily runoff were precipitation for the same day as runoff and precipitation for combinations of days 1 to 60 prior to the day of runoff.

The next step of this monotonic trend analysis was to use LOWESS analysis to remove the variation in time caused by variation in precipitation. The LOWESS equations for precipitation and time used the same explanatory variables that were used in the LOWESS equations for precipitation and streamflow. These precipitation-time equations had $R^{2}$ values ranging from 0.23 to 0.69 for total flows (table 14), 0.26 to 0.73 for low flows (table 16), and 0.46 to 0.62 for storm runoff (table 17).

The next step of the trend analysis was to use the Kendall tau test to determine significant trends. Three sets of data were tested for comparison: (1) streamflow values and time (years); (2) the LOWESS precipitation-streamflow residuals and time; and (3) the LOWESS precipitationstreamflow residuals and the LOWESS precipitation-time residuals. The LOWESS residuals can be called "precipitationadjusted" or "adjusted" values. Trend tests on the second and third sets of data (adjusted values) can be used to determine if there were significant trends in streamflow caused by factors other than precipitation.
Factors other than precipitation caused significant decreasing trends in streamflow (adjusted flow is significantly related to adjusted time; tables 18-20). Adjusted total flows and low flows had similar seasonal trends; summer, fall, and early winter flows (June-December) significantly decreased, and late winter and early spring flows (January-March) had no significant trends. Only 3 months of storm runoff could be tested for trends in adjusted values. Adjusted storm runoff for July and September had significant decreasing trends, and adjusted storm runoff for October had a nearly significant decreasing trend $(\mathrm{p}=0.079)$. Unadjusted storm runoff for the winter and early spring had no significant decreasing trends, but it is not known if there were effects of factors other than precipitation.

Trends in unadjusted and adjusted total flows for all months are shown in figure 13. The adjusted total flows in the figure are LOWESS residuals plus the mean of the log monthly flows for the entire record. The adjusted streamflows generally had lower slopes and much less interannual variability than the unadjusted streamflows. Unadjusted flows for July, August, September, and October appeared to have a break in the time trend between 1950 and 1970; the later flows have a steeper decrease over time than the earlier flows. The adjusted streamflows also had similar breaks in slope, but the difference in slopes between early and later flows is much less than that for the unadjusted flows. The steeper slopes of adjusted flows after 1950-70 indicate that factors other than precipitation had a stronger effect on the decreasing flows in the later time periods rather than in the earlier time periods.

Trends in unadjusted and adjusted monthly low flows had similar patterns as those for monthly total flows (fig. 14). The adjusted low flows had less interannual variability and lower slopes than the unadjusted low flows. Also, some breaks or shifts in the trends or slopes in the adjusted low flows are less pronounced than those in the unadjusted low flows.

Trends in unadjusted storm runoff are shown in figure 15 for all months except April and May, which had too few runoff events (fewer than 10). Trends in adjusted storm runoff are also shown for July, September, and October. The difference in trends of unadjusted flows compared to adjusted flows is clearly shown in the trends for October storm runoff. The trend in unadjusted flows had a sharp rise from 1970 to 2002, an overall positive slope for the record, and a trend-test pvalue of 0.333 (table 20). This rise was caused by larger than average October precipitation. Total precipitation from 1970 to 2002 was 35 percent larger than the long-term average (1913-2002), and maximum daily precipitation was 16 percent larger than the long-term average (1913-2002). When this effect of precipitation is removed from the storm runoff, the trend in adjusted storm runoff had an overall negative slope and a trend test p-value of 0.347 . 
Table 16. Results of LOWESS regression analyses between monthly precipitation at Tombstone, Arizona, and monthly low flow for the San Pedro River at Charleston, Arizona, and between precipitation at Tombstone and time, 1931-2002

$\left[R^{2}\right.$, coefficient of multiple determination]

\begin{tabular}{|c|c|c|c|c|c|c|c|c|}
\hline \multirow[b]{4}{*}{ Month } & \multirow{4}{*}{$\begin{array}{c}\text { Number of } \\
\text { years } \\
\text { analyzed }\end{array}$} & \multicolumn{7}{|c|}{ LOWESS regression models ${ }^{2}$} \\
\hline & & \multirow{3}{*}{$\begin{array}{c}\text { Explanatory variables } \\
\begin{array}{c}\text { Monthly precipitation } \\
\text { (inches) }\end{array}\end{array}$} & \multicolumn{6}{|c|}{ Response variable } \\
\hline & & & \multicolumn{3}{|c|}{$\begin{array}{c}\text { Low flow } \\
\text { (cubic feet per second) }\end{array}$} & \multicolumn{3}{|c|}{$\begin{array}{c}\text { Time } \\
\text { (years) }\end{array}$} \\
\hline & & & $R^{2}$ & $\begin{array}{l}\text { Standard error } \\
\text { (log units) }\end{array}$ & Span $^{3}$ & $R^{2}$ & $\begin{array}{l}\text { Standard error } \\
\text { (years) }\end{array}$ & Span $^{3}$ \\
\hline January & 55 & Oct., Nov., Dec., and Jan. & 0.80 & 0.163 & 0.75 & 0.54 & 23.43 & 0.75 \\
\hline February & 55 & Nov., Dec., and Jan. & .82 & .141 & .50 & .61 & 19.38 & .50 \\
\hline March & 60 & Jan., Feb., and Mar. & .58 & .138 & .75 & .61 & 20.55 & .50 \\
\hline April & 60 & Jan., Feb., and Mar. & .60 & .139 & .50 & .61 & 20.55 & .50 \\
\hline May & 55 & Nov., Dec., Jan., and Mar. & .75 & .178 & .75 & .73 & 23.41 & .60 \\
\hline June & 56 & Dec., Jan., and June & .57 & .246 & .75 & .67 & 18.63 & .50 \\
\hline July & 63 & Apr., May, June, and July & .81 & .368 & .60 & .72 & 20.41 & .60 \\
\hline August & 54 & Dec., July, and Aug. & .67 & .377 & .75 & .27 & 23.08 & .75 \\
\hline September & 59 & Jan., Aug., and Sept. & .60 & .270 & .60 & .32 & 22.51 & .60 \\
\hline October & 62 & May, Aug., and Sept. & .66 & .249 & .75 & .44 & 19.86 & .75 \\
\hline November & 62 & Aug. and Oct. & .65 & .154 & .60 & .26 & 20.43 & .60 \\
\hline December & 61 & Aug., Oct., and Nov. & .59 & .124 & .75 & .47 & 21.84 & .50 \\
\hline
\end{tabular}

${ }^{1}$ Time period for analyses was 1931-2002.

${ }^{2}$ LOWESS regression models:

Response variable, low flow: $\log Q_{\mathrm{n}}=\log P_{1}+\log P_{2}+\log P_{\mathrm{n}}$

where $Q_{\mathrm{n}}$ is 3-day low flow for month $\mathrm{n}$, in cubic feet per second, and $P_{\mathrm{n}}$ is precipitation for month $\mathrm{n}$, in inches.

Response variable, time: $T_{\mathrm{n}}=\log P_{1}+\log P_{2}+\log P_{\mathrm{n}}$

where $T_{\mathrm{n}}$ is time for month $\mathrm{n}$, in years, and $\mathrm{Pn}$ is precipitation for month $\mathrm{n}$, in inches.

${ }^{3}$ Span is a parameter that controls the window width and smoothness of the fitted LOWESS model. As the span is increased, the window width is increased and more points influence the magnitude of the fitted values. Thus, a larger span will have a smoother fitted model than a smaller span. 
Table 17. Results of LOWESS regression analyses between precipitation at Tombstone, Arizona, and maximum daily storm runoff for the San Pedro River at Charleston, Arizona; and between precipitation at Tombstone and time, 1913-2002, for selected months

$\left[R^{2}\right.$, coefficient of multiple determination]

\begin{tabular}{|c|c|c|c|c|c|c|c|c|}
\hline \multirow[b]{3}{*}{ Month } & \multirow[b]{3}{*}{$\begin{array}{l}\text { Number of } \\
\text { years } \\
\text { analyzed }{ }^{1}\end{array}$} & \multicolumn{7}{|c|}{ LOWESS regression models ${ }^{2}$} \\
\hline & & Explanatory variables & \multicolumn{6}{|c|}{ Response variable } \\
\hline & & $\begin{array}{l}\text { Monthly precipitation } \\
\text { (inches) }\end{array}$ & $R^{2}$ & $\begin{array}{l}\text { Standard } \\
\text { error } \\
\text { (log units) }\end{array}$ & Span $^{3}$ & $R^{2}$ & $\begin{array}{c}\text { Standard } \\
\text { error } \\
\text { (years) }\end{array}$ & Span $^{3}$ \\
\hline June & 34 & $\mathrm{p}_{0}$ and $\mathrm{p}_{1-10}$ & 0.32 & 0.613 & 0.75 & $\left({ }^{4}\right)$ & $\left({ }^{4}\right)$ & $\left({ }^{4}\right)$ \\
\hline July & 78 & $\mathrm{p}_{0}, \mathrm{p}_{1-10}, \mathrm{p}_{11-30}$, and $\mathrm{p}_{31-60}$ & .64 & .462 & .75 & .62 & 26.77 & .60 \\
\hline October & 36 & $\mathrm{p}_{0}$ and $\mathrm{p}_{1-30}$ & .84 & .427 & .50 & .50 & 26.33 & .60 \\
\hline
\end{tabular}

${ }^{1}$ Time period for analyses was 1913-2002.

${ }^{2}$ LOWESS regression models:

Response variable, maximum daily storm runoff: $\log Q_{\mathrm{n}}=\log P_{1}+\log P_{2}+\log P_{\mathrm{m}}$, where $Q$ is maximum daily mean flow for month n, in cubic feet per second, and $P_{\mathrm{m}}$ is precipitation for indicated days previous to day of runoff, in inches ( $p_{0}$ is precipitation for day of runoff, $p_{1-10}$ is cumulative precipitation for days 1 through 10 prior to runoff).

Response variable, time: $T_{\mathrm{n}}=\log P_{1}+\log P_{2}+\log P_{\mathrm{m}}$, where $T$ is time for month $\mathrm{n}$, in years, and $P_{\mathrm{m}}$ is precipitation for indicated days previous to day of runoff, in inches.

${ }^{3}$ Span is a parameter that controls the window width and smoothness of the fitted LOWESS model. As the span is increased, the window width is increased and more points influence the magnitude of the fitted values. Thus, a larger span will have a smoother fitted model than a smaller span.

${ }^{4}$ LOWESS regression analysis between precipitation and time was not done because the LOWESS equation between precipitation and maximum runoff was not sufficiently accurate $\left(R^{2}<0.50\right)$. 
Table 18. Trends in monthly total streamflow and monthly total streamflow adjusted for variation in precipitation, San Pedro River at Charleston, Arizona, 1913-2002

$[<$, less than; >, greater than]

Total streamflow (1913-2002)

\begin{tabular}{|c|c|c|c|c|c|c|c|}
\hline \multirow[b]{3}{*}{ Month } & \multirow{3}{*}{$\begin{array}{c}\text { Number of } \\
\text { years analyzed }\end{array}$} & \multicolumn{6}{|c|}{ Kendall tau trend test } \\
\hline & & \multicolumn{2}{|c|}{ Streamflow and time } & \multicolumn{2}{|c|}{ Adjusted streamflow and time ${ }^{2}$} & \multicolumn{2}{|c|}{$\begin{array}{l}\text { Adjusted streamflow } \\
\text { and adjusted time }^{3}\end{array}$} \\
\hline & & Slope $^{4}$ & $\mathrm{p}$-value & Slope $^{4}$ & p-value & Slope $^{4}$ & $\mathrm{p}$-value \\
\hline January & 72 & $\mathrm{n}$ & 0.017 & $\mathrm{n}$ & 0.208 & $\mathrm{n}$ & 0.061 \\
\hline February & 72 & $\mathrm{n}$ & .930 & $\mathrm{p}$ & .428 & $\mathrm{p}$ & .198 \\
\hline March & 76 & $\mathrm{n}$ & .996 & $\mathrm{p}$ & .487 & $\mathrm{p}$ & .300 \\
\hline April & 76 & $\mathrm{p}$ & .542 & $\mathrm{p}$ & .638 & $\mathrm{p}$ & .854 \\
\hline May & 76 & $\mathrm{n}$ & .081 & $\mathrm{n}$ & .449 & $\mathrm{n}$ & .135 \\
\hline June & 73 & $\mathrm{n}$ & .001 & $\mathrm{n}$ & $<.001$ & $\mathrm{n}$ & .018 \\
\hline July & 76 & $\mathrm{n}$ & $<.001$ & $\mathrm{n}$ & .007 & $\mathrm{n}$ & $<.001$ \\
\hline August & 74 & $\mathrm{n}$ & $<.001$ & $\mathrm{n}$ & .001 & $\mathrm{n}$ & $<.001$ \\
\hline September & 79 & $\mathrm{n}$ & $<.001$ & $\mathrm{n}$ & $<.001$ & $\mathrm{n}$ & $<.001$ \\
\hline October & 79 & $\mathrm{n}$ & .029 & $\mathrm{n}$ & $<.001$ & $\mathrm{n}$ & $<.001$ \\
\hline November & 77 & $\mathrm{n}$ & $<.001$ & $\mathrm{n}$ & $<.001$ & $\mathrm{n}$ & $<.001$ \\
\hline December & 76 & $\mathrm{n}$ & .018 & $\mathrm{n}$ & $<.001$ & $\mathrm{n}$ & $<.001$ \\
\hline
\end{tabular}

${ }^{1}$ Average streamflow.

${ }^{2}$ Variation in streamflow that was caused by variation in precipitation was removed by LOWESS regression analysis.

${ }^{3}$ Variations in streamflow and time that were caused by variation in precipitation were removed by LOWESS regression analysis.

${ }^{4}$ Slope of trend: $\mathrm{n}$ is negative and $\mathrm{p}$ is positive.

\begin{tabular}{|c|l|l|}
\cline { 3 - 3 } \multicolumn{2}{c|}{} & $\mathrm{p}$-value \\
\hline $\mathrm{n}$ or $\mathrm{p}$ & no significant trend & $>0.10$ \\
\hline $\mathrm{n}$ & nearly significant negative trend & $0.05-0.10$ \\
\hline $\mathrm{n}$ & significant negative trend & $<0.05$ \\
\hline
\end{tabular}


Table 19. Trends in monthly low flow and monthly low flow adjusted for variation in precipitation, San Pedro River at Charleston, Arizona, 1931-2002

$[<$, less than; $>$, greater than $]$

\begin{tabular}{|c|c|c|c|c|c|c|c|}
\hline \multirow[b]{4}{*}{ Month } & \multirow{4}{*}{$\begin{array}{c}\text { Number of } \\
\text { years analyzed }\end{array}$} & \multicolumn{5}{|c|}{ Low flow (1931-2002) } & \\
\hline & & \multicolumn{6}{|c|}{ Kendall tau trend test } \\
\hline & & \multicolumn{2}{|c|}{ Flow and time } & \multicolumn{2}{|c|}{ Adjusted flow and time ${ }^{2}$} & \multicolumn{2}{|c|}{$\begin{array}{l}\text { Adjusted flow and } \\
\text { adjusted time }\end{array}$} \\
\hline & & Slope ${ }^{4}$ & $\mathrm{p}$-value & Slope $^{4}$ & p-value & Slope $^{4}$ & p-value \\
\hline January & 55 & $\mathrm{n}$ & 0.014 & $\mathrm{n}$ & 0.089 & $\mathrm{n}$ & 0.245 \\
\hline February & 55 & $\mathrm{n}$ & .292 & $\mathrm{n}$ & 965 & $\mathrm{n}$ & .532 \\
\hline March & 60 & $\mathrm{p}$ & .527 & $\mathrm{p}$ & .342 & $\mathrm{p}$ & .178 \\
\hline April & 60 & $\mathrm{n}$ & .139 & $\mathrm{n}$ & .293 & $\mathrm{n}$ & .030 \\
\hline May & 55 & $\mathrm{n}$ & $<.001$ & $\mathrm{n}$ & .007 & $\mathrm{n}$ & .163 \\
\hline June & 56 & $\mathrm{n}$ & $<.001$ & $\mathrm{n}$ & .002 & $\mathrm{n}$ & .001 \\
\hline July & 63 & $\mathrm{n}$ & $<.001$ & $\mathrm{n}$ & .073 & $\mathrm{n}$ & $<.001$ \\
\hline August & 54 & $\mathrm{n}$ & $<.001$ & $\mathrm{n}$ & .002 & $\mathrm{n}$ & $<.001$ \\
\hline September & 59 & $\mathrm{n}$ & $<.001$ & $\mathrm{n}$ & $<.001$ & $\mathrm{n}$ & $<.001$ \\
\hline October & 62 & $\mathrm{n}$ & $<.001$ & $\mathrm{n}$ & .003 & $\mathrm{n}$ & $<.001$ \\
\hline November & 62 & $\mathrm{n}$ & .007 & $\mathrm{n}$ & $<.001$ & $\mathrm{n}$ & $<.001$ \\
\hline December & 61 & $\mathrm{n}$ & .003 & $\mathrm{n}$ & $<.001$ & $\mathrm{n}$ & $<.001$ \\
\hline
\end{tabular}

${ }^{1}$ Three-day low flow.

${ }^{2}$ Variation in low flow that was caused by variation in precipitation was removed by LOWESS regression analysis.

${ }^{3}$ Variations in low flow and time that were caused by variation in precipitation were removed by LOWESS regression analysis.

${ }^{4}$ Slope of trend: $\mathrm{n}$ is negative and $\mathrm{p}$ is positive.

\begin{tabular}{|c|l|l|}
\cline { 3 - 3 } \multicolumn{2}{c|}{} & $\mathrm{p}$-value \\
\hline $\mathrm{n}$ or $\mathrm{p}$ & no significant trend & $>0.10$ \\
\hline $\mathrm{n}$ & nearly significant negative trend & $0.05-0.10$ \\
\hline $\mathrm{n}$ & significant negative trend & $<0.05$ \\
\hline
\end{tabular}


Table 20. Trends in maximum daily storm runoff and maximum daily storm runoff adjusted for variation in precipitation, by month, San Pedro River at Charleston, Arizona, 1913-2002

$[<$, less than; >, greater than $]$

\begin{tabular}{|c|c|c|c|c|c|c|c|}
\hline \multirow[b]{4}{*}{ Month } & \multicolumn{7}{|c|}{ Maximum daily storm runoff (1913-2002)' } \\
\hline & \multirow{3}{*}{$\begin{array}{c}\text { Number of } \\
\text { years analyzed }\end{array}$} & \multicolumn{6}{|c|}{ Kendall tau trend test } \\
\hline & & \multicolumn{2}{|c|}{ Runoff and time } & \multicolumn{2}{|c|}{$\begin{array}{c}\text { Adjusted runoff } \\
\text { and time }\end{array}$} & \multicolumn{2}{|c|}{$\begin{array}{l}\text { Adjusted runoff and } \\
\text { adjusted time }^{3}\end{array}$} \\
\hline & & Slope $^{4}$ & p-value & Slope $^{4}$ & $\mathrm{p}$-value & Slope $^{4}$ & p-value \\
\hline January & 18 & $\mathrm{n}$ & 0.820 & $\left({ }^{6}\right)$ & $\left({ }^{6}\right)$ & $\left({ }^{6}\right)$ & $\left({ }^{6}\right)$ \\
\hline February & 17 & $\mathrm{n}$ & .902 & $\left({ }^{6}\right)$ & $\left({ }^{6}\right)$ & ${ }^{(6)}$ & $\left({ }^{6}\right)$ \\
\hline March & 15 & $\mathrm{p}$ & .020 & ${ }^{(6)}$ & $\left({ }^{6}\right)$ & $\left({ }^{6}\right)$ & $\left({ }^{6}\right)$ \\
\hline April & 7 & $\left({ }^{5}\right)$ & $\left({ }^{5}\right)$ & $\left({ }^{5}\right)$ & $\left({ }^{5}\right)$ & $\left({ }^{5}\right)$ & $\left({ }^{5}\right)$ \\
\hline May & 3 & $\left({ }^{5}\right)$ & $\left({ }^{5}\right)$ & $\left({ }^{5}\right)$ & $\left({ }^{5}\right)$ & $\left({ }^{5}\right)$ & $\left({ }^{5}\right)$ \\
\hline June & 34 & $\mathrm{n}$ & .382 & $\left({ }^{7}\right)$ & $\left({ }^{7}\right)$ & $\left({ }^{7}\right)$ & $\left({ }^{7}\right)$ \\
\hline July & 78 & $\mathrm{n}$ & $<.001$ & $\mathrm{n}$ & .005 & $\mathrm{n}$ & .010 \\
\hline August & 78 & $\mathrm{n}$ & $<.001$ & $\left({ }^{7}\right)$ & $\left({ }^{7}\right)$ & $\left({ }^{7}\right)$ & $\left({ }^{7}\right)$ \\
\hline September & 71 & $\mathrm{n}$ & .002 & $\mathrm{n}$ & .013 & $\mathrm{n}$ & .007 \\
\hline October & 36 & $\mathrm{p}$ & .333 & $\mathrm{n}$ & .347 & $\mathrm{n}$ & .079 \\
\hline November & 17 & $\mathrm{n}$ & .265 & $\left({ }^{6}\right)$ & $\left({ }^{6}\right)$ & $\left({ }^{6}\right)$ & $\left(^{6}\right)$ \\
\hline December & 19 & $\mathrm{p}$ & .624 & $\left({ }^{6}\right)$ & $\left({ }^{6}\right)$ & $\left({ }^{6}\right)$ & $\left(^{6}\right)$ \\
\hline
\end{tabular}

${ }^{1}$ Maximum daily mean streamflow for month.

${ }^{2}$ Variation in runoff that was caused by variation in precipitation was removed by LOWESS regression analysis.

${ }^{3}$ Variations in runoff and time that were caused by variation in precipitation were yremoved by LOWESS regression analysis.

${ }^{4}$ Slope of trend: $\mathrm{n}$ is negative and $\mathrm{p}$ is positive.

${ }^{5}$ Sufficient data were not available to perform trend analysis.

${ }^{6}$ Sufficient data were not available to perform LOWESS regression analysis and to create adjusted values of runoff and time.

${ }^{7}$ LOWESS regression equations for June and August runoff were not accurate enough to use for adjusted values of runoff and time.

\begin{tabular}{|c|l|l|}
\cline { 3 - 3 } \multicolumn{2}{c|}{} & $\mathrm{p}$-value \\
\hline $\mathrm{n}$ or $\mathrm{p}$ & no significant trend & $>0.10$ \\
\hline $\mathrm{n}$ & nearly significant negative trend & $0.05-0.10$ \\
\hline $\mathrm{n}$ & significant negative trend & $<0.05$ \\
\hline $\mathrm{p}$ & significant positive trend & $<0.05$ \\
\hline
\end{tabular}


AVERAGE FLOW

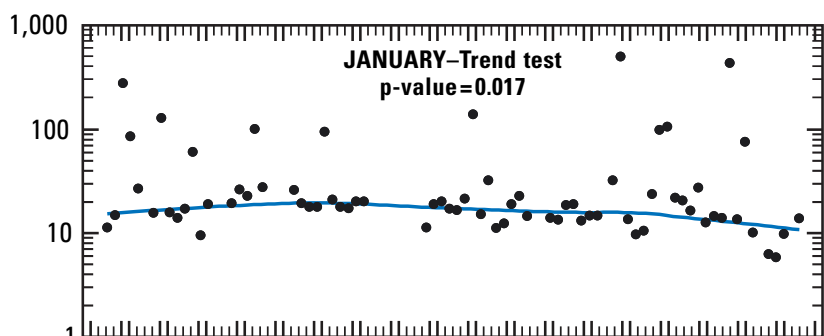

1,000
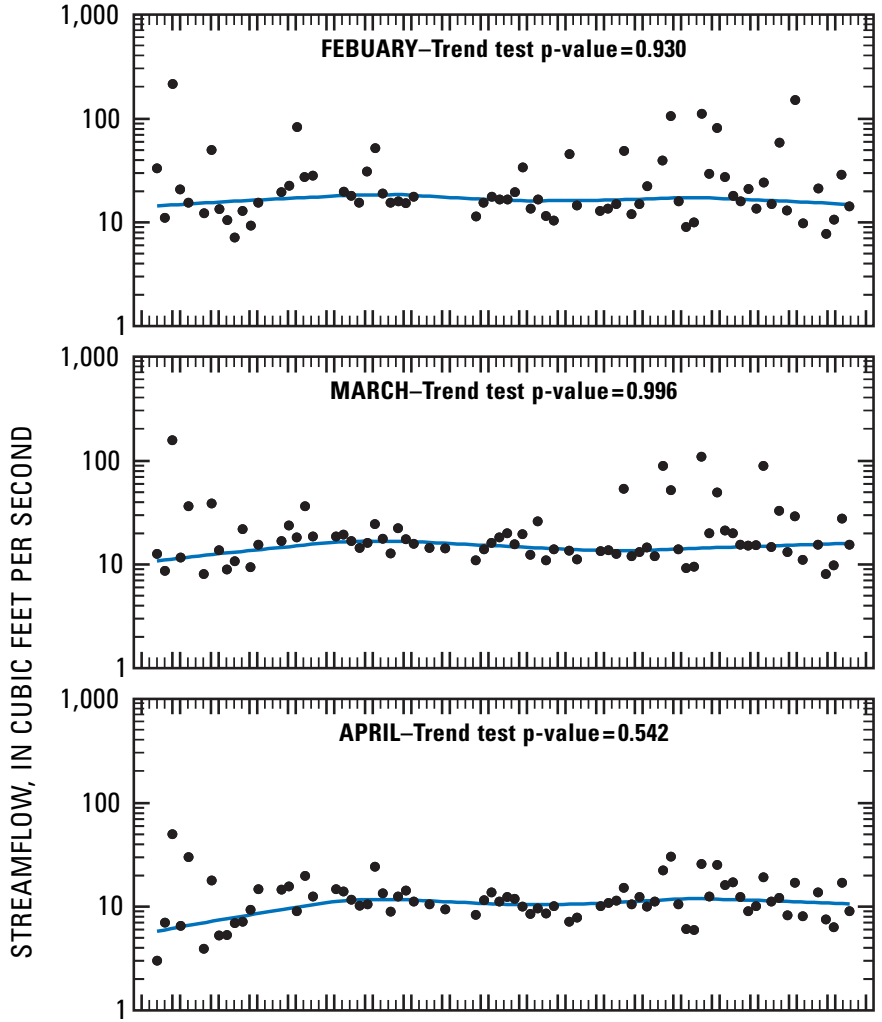

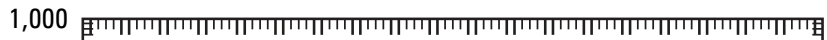

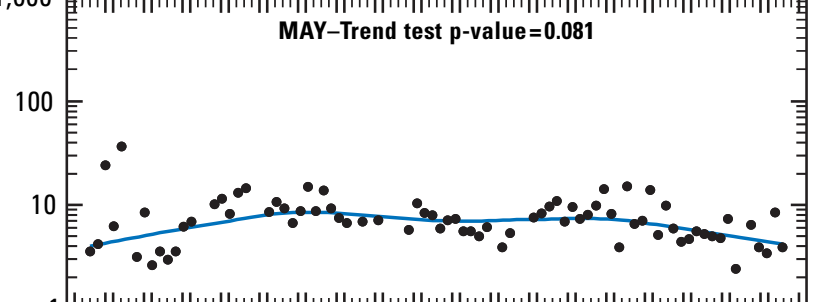

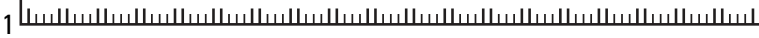

1,000 堲

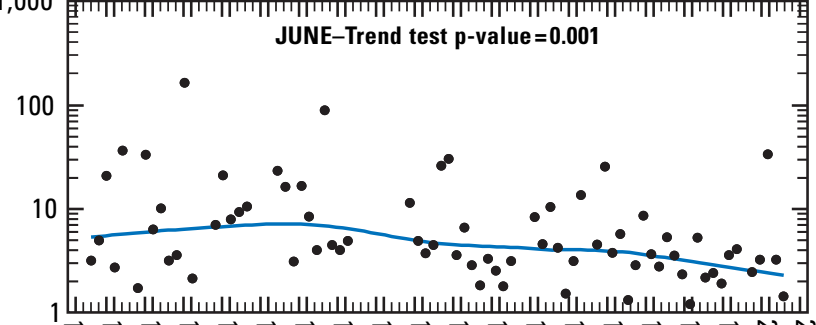

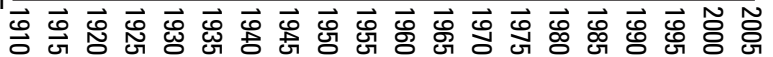

AVERAGE FLOW ADJUSTED FOR VARIATION IN PRECIPITATION

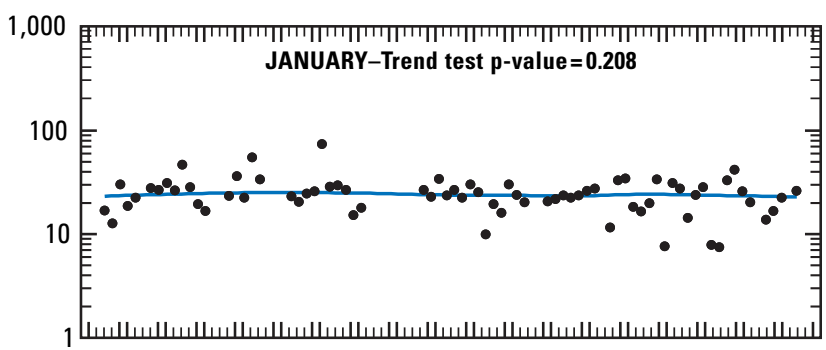

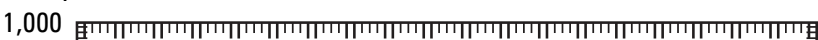
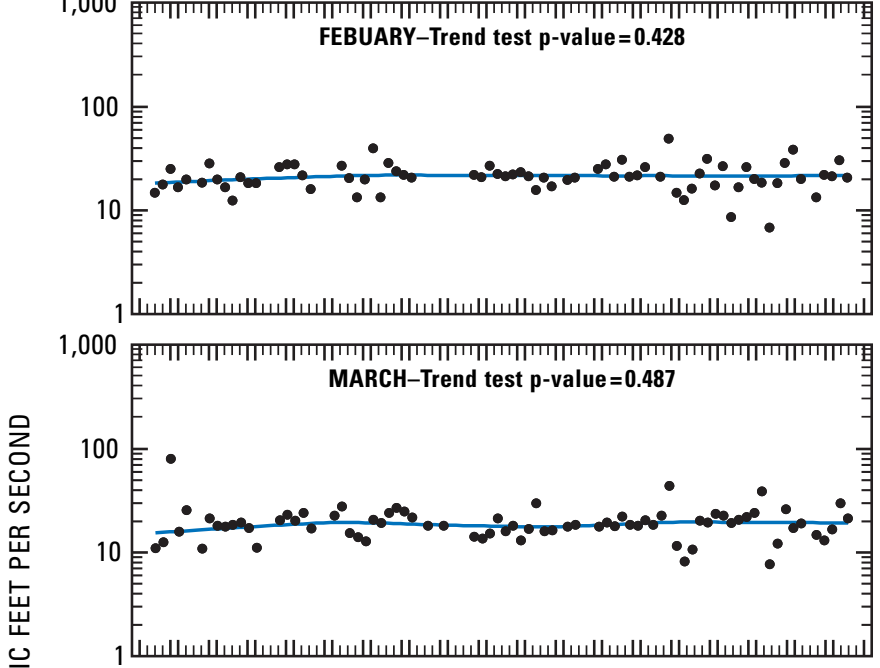

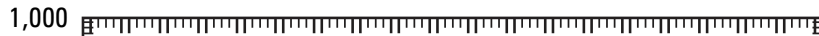

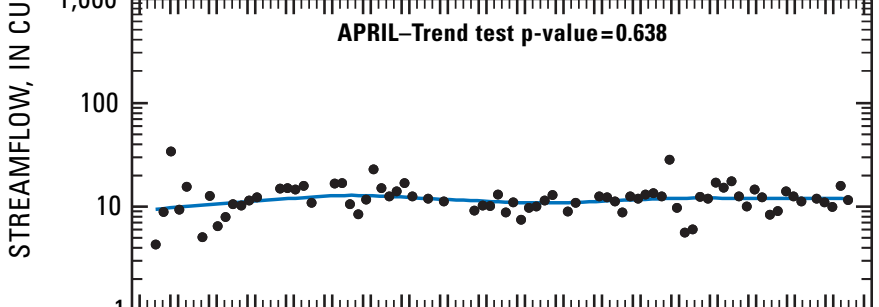

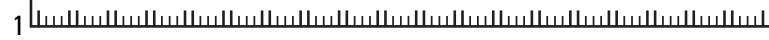

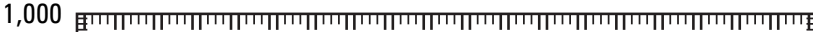
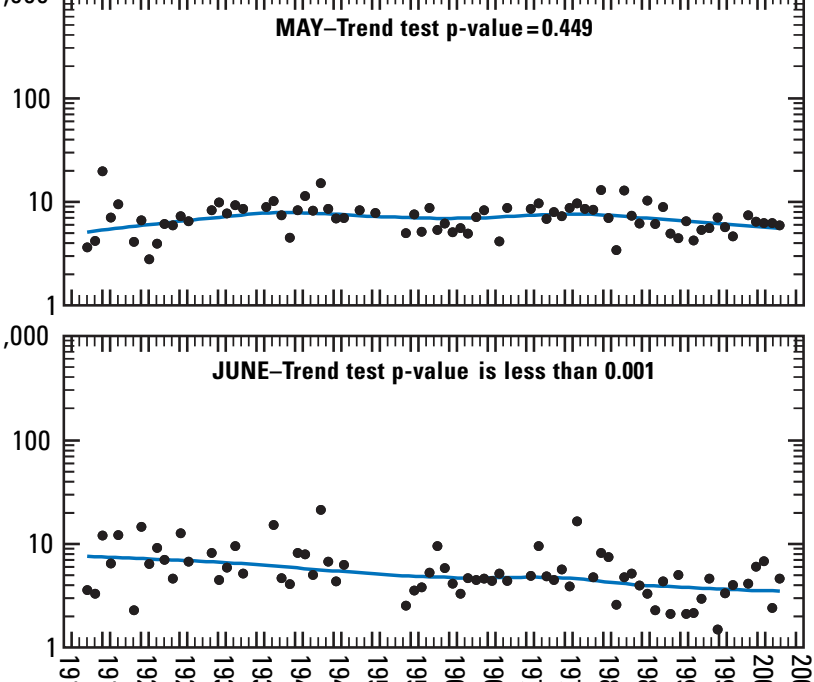

Figure 13. Trends in monthly total streamflow and monthly total streamflow adjusted for variation in precipitation, January-December, San Pedro River at Charleston, Arizona. Blue line is LOWESS fit to data. 
AVERAGE FLOW

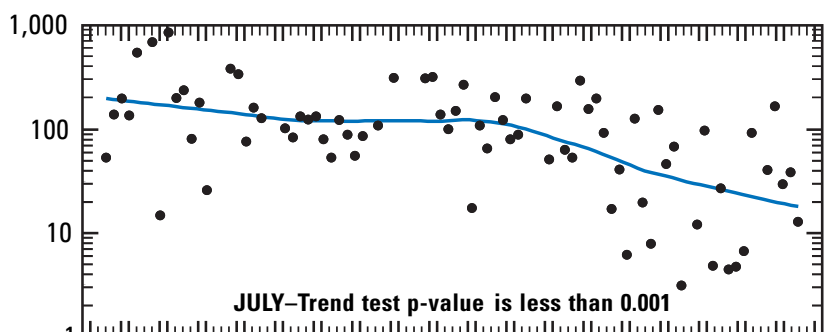

للسللسللسللسللسللسللسللسللسللسللسللس 1
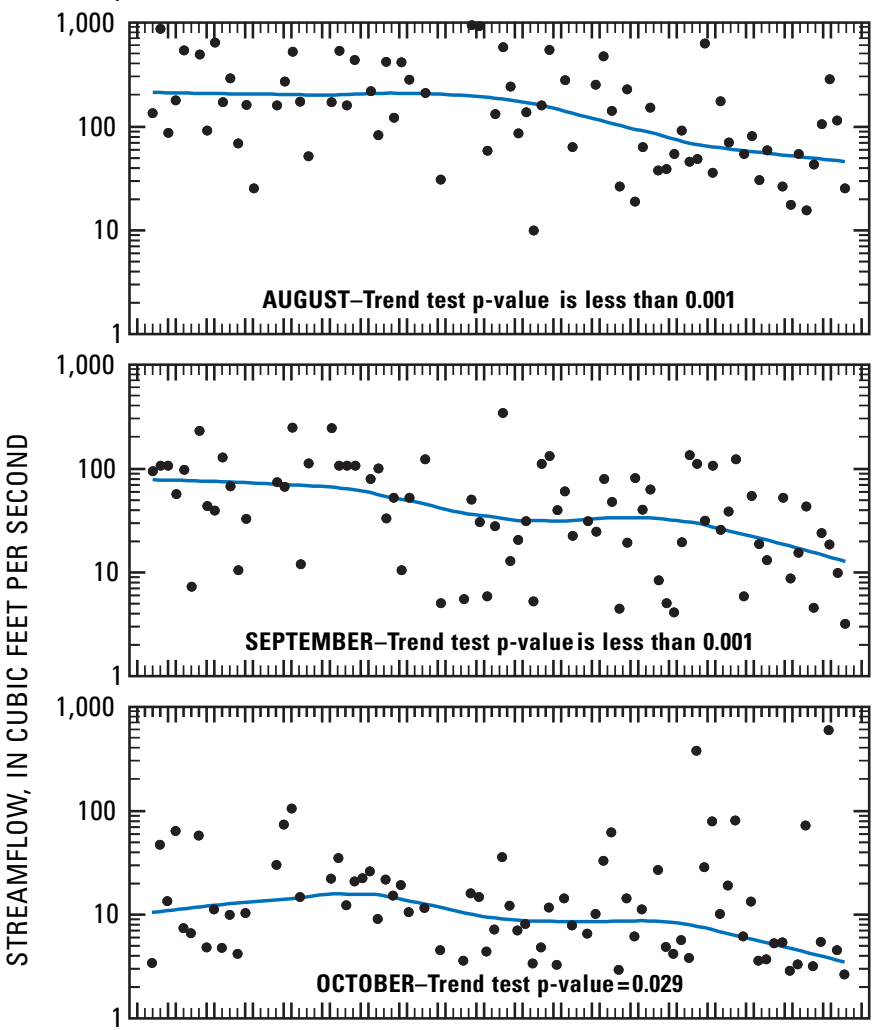

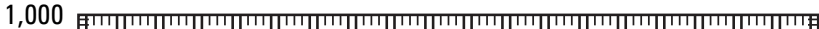

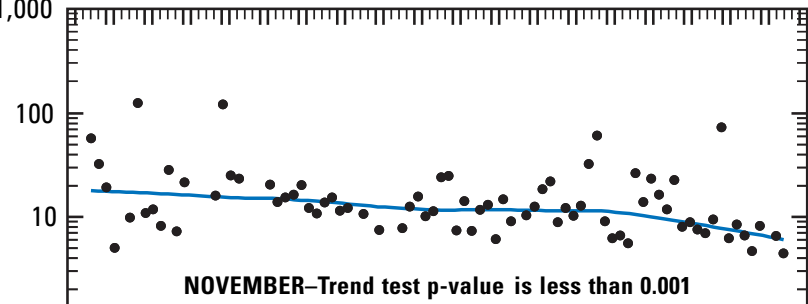

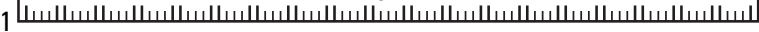

1,000 Fाता

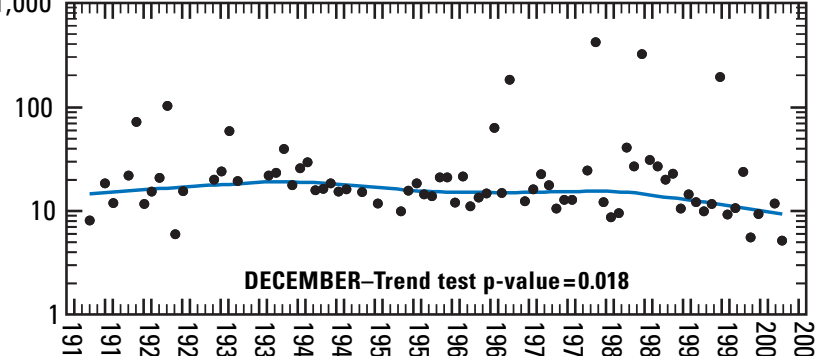

AVERAGE FLOW ADJUSTED FOR VARIATION IN PRECIPITATION

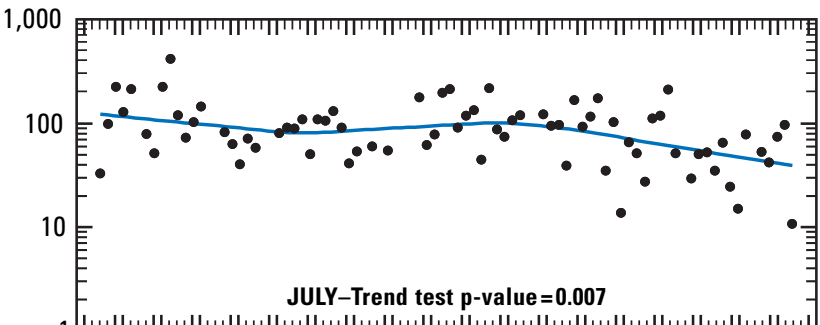

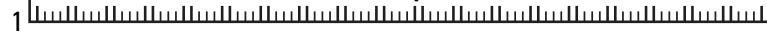

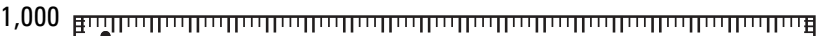

100

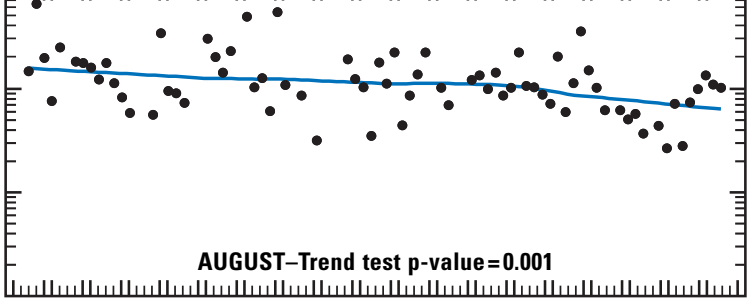

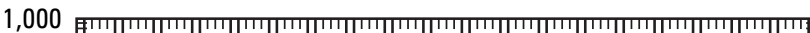

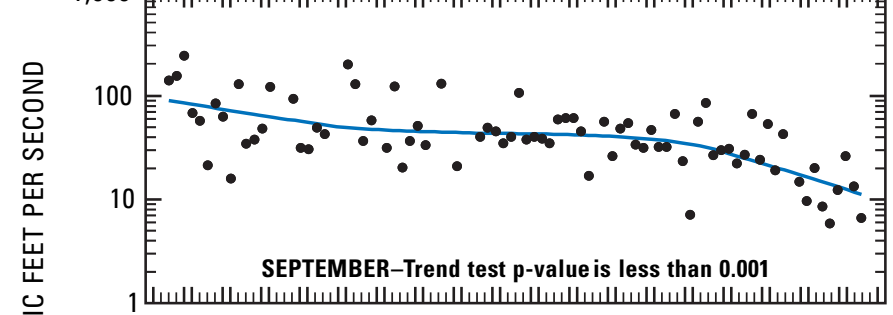

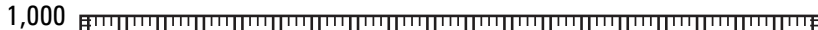

ב

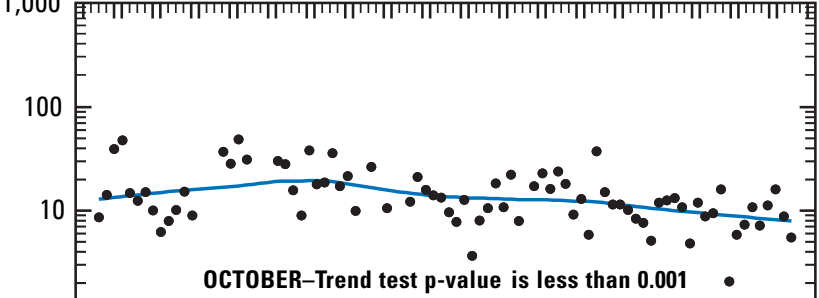

للسللسللسللسللسللسللسللسللسللسلسلسللسللسللسلسلسلسلسللسللسللسلسلس

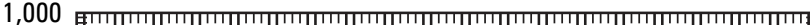

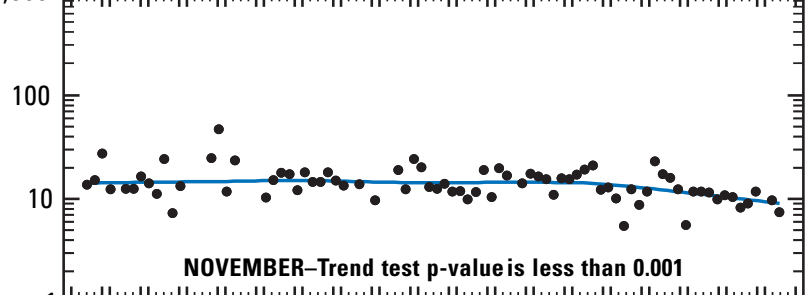

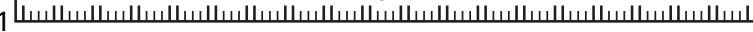

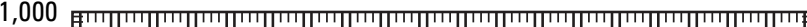

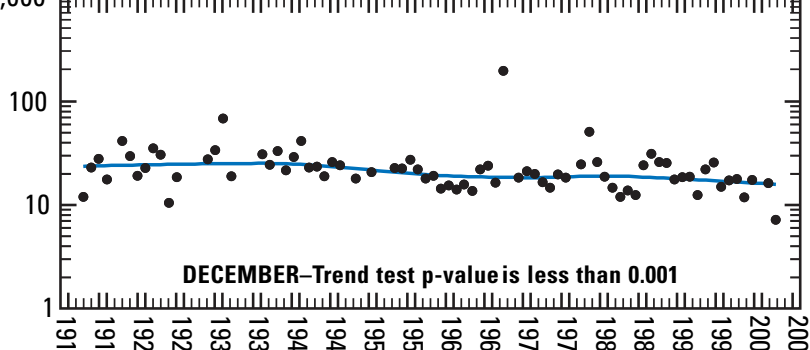

Figure 13. Continued. 
LOW FLOW

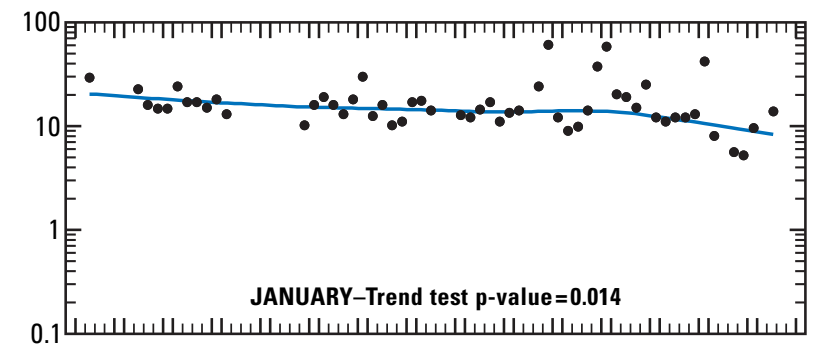

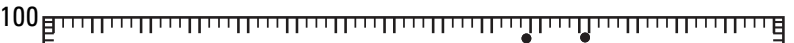
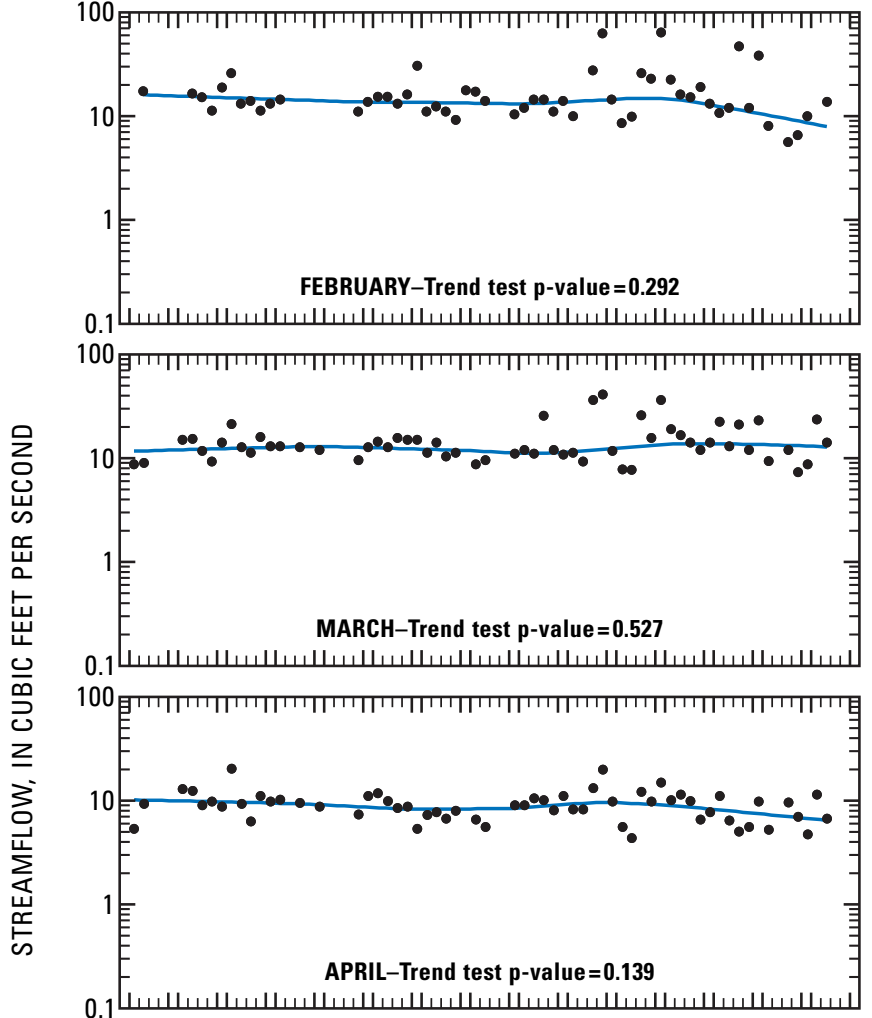

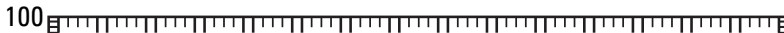
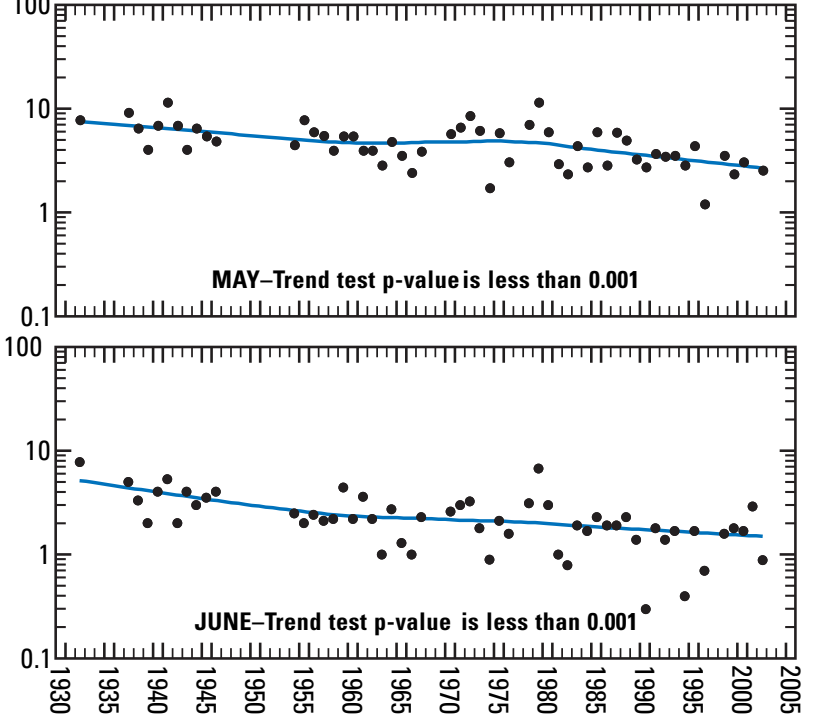

LOW FLOW ADJUSTED FOR VARIATION IN PRECIPITATION
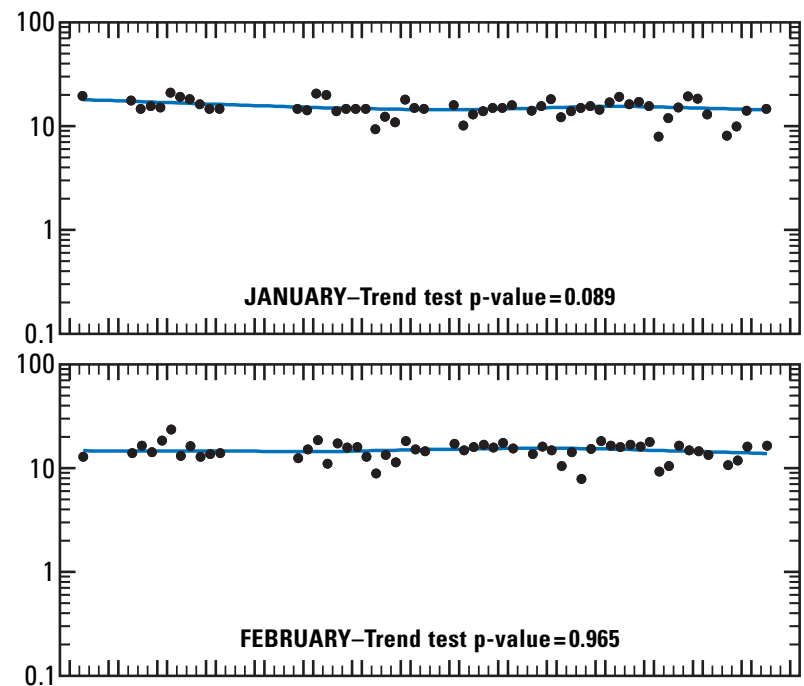

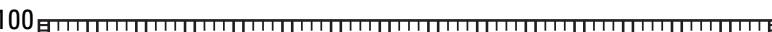

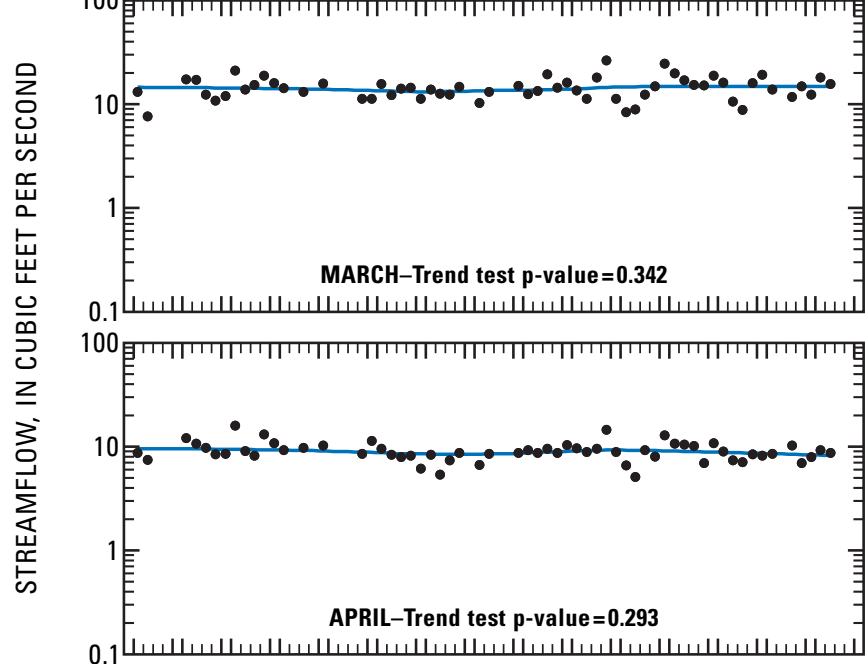

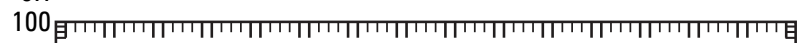
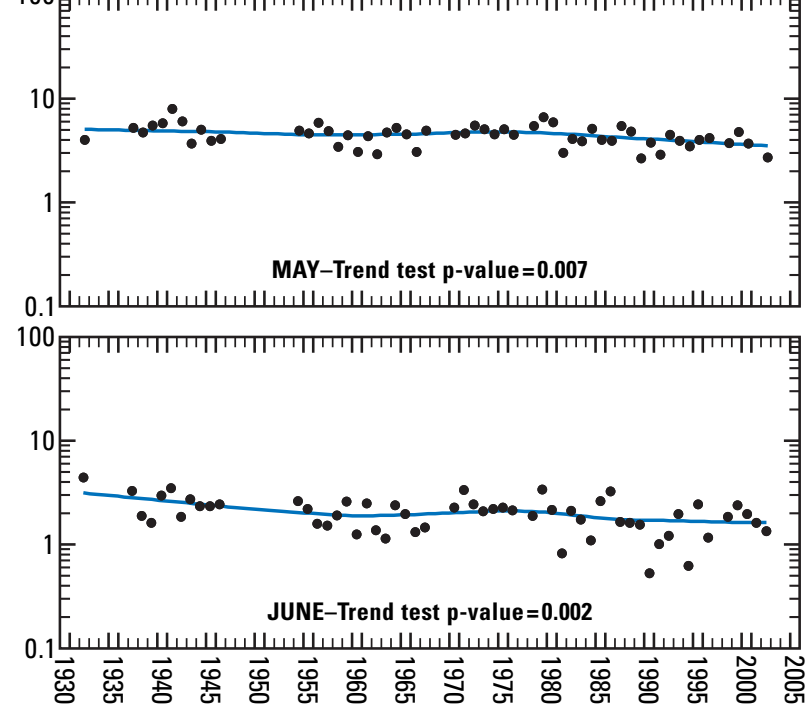

Figure 14. Trends in monthly low flow and monthly low flow adjusted for variation in precipitation, January-December, San Pedro River at Charleston, Arizona. Blue line is LOWESS fit to data. 
LOW FLOW

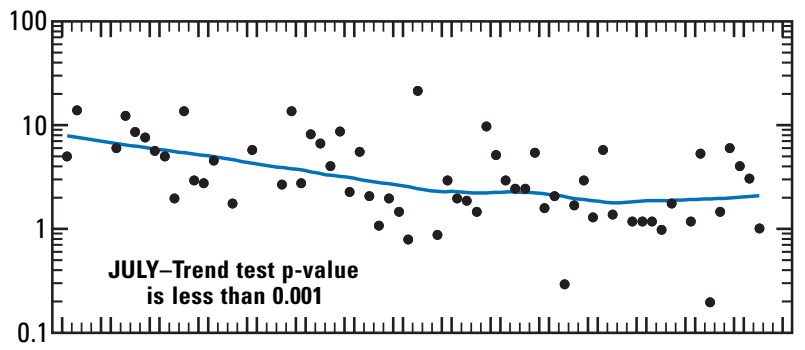

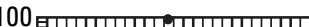
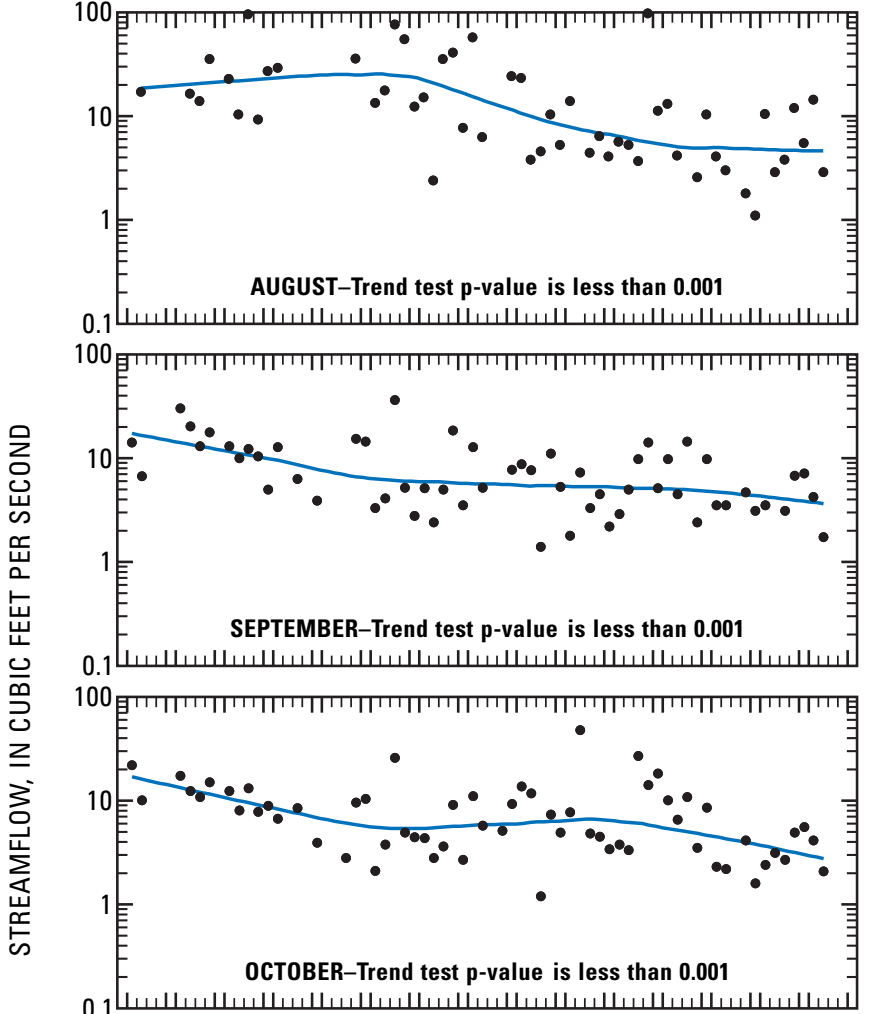

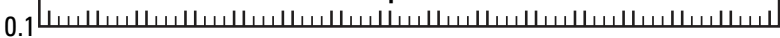
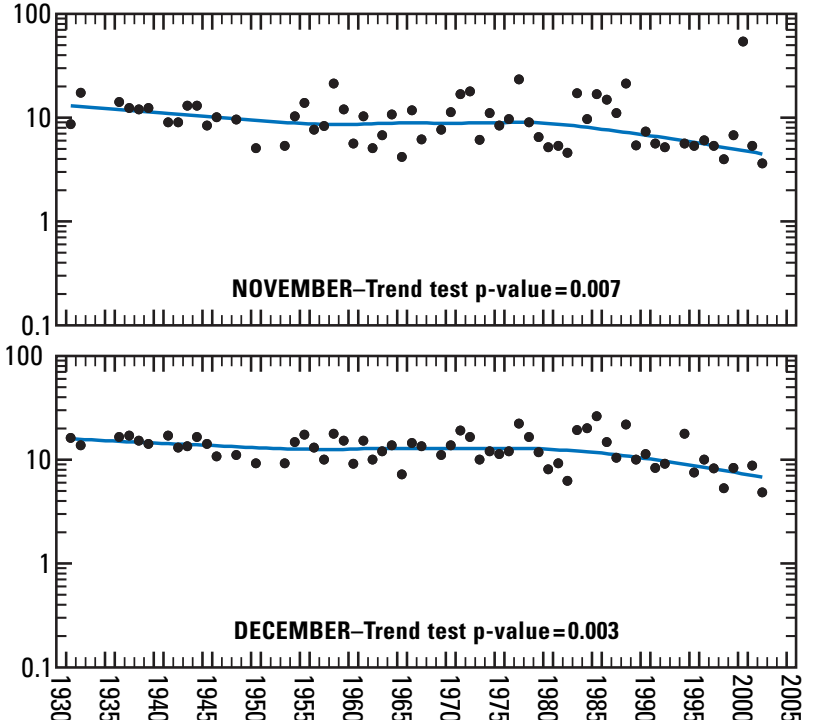

LOW FLOW ADJUSTED FOR VARIATION IN PRECIPITATION

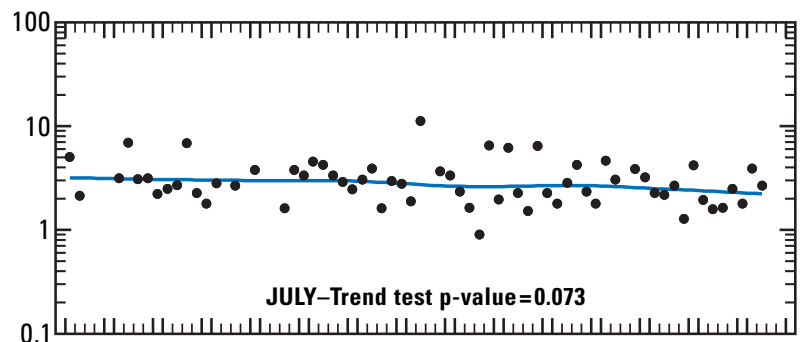

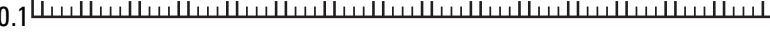

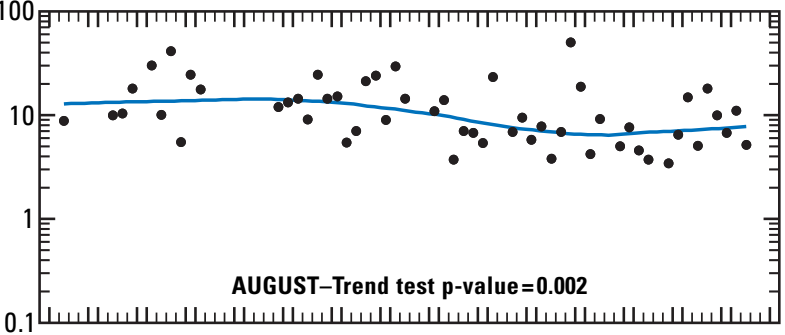

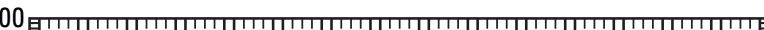

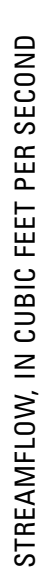

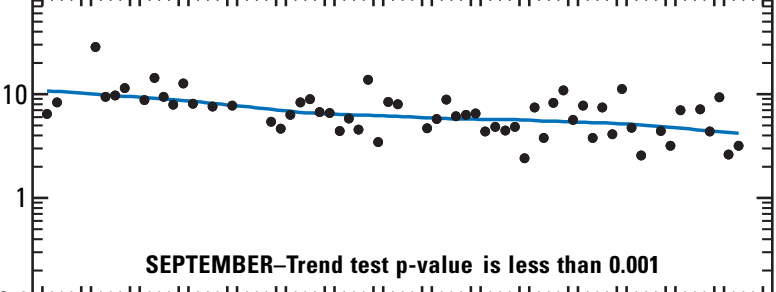

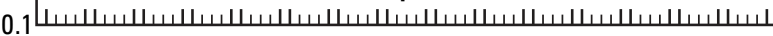

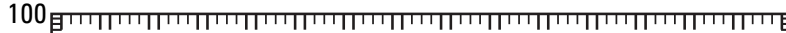

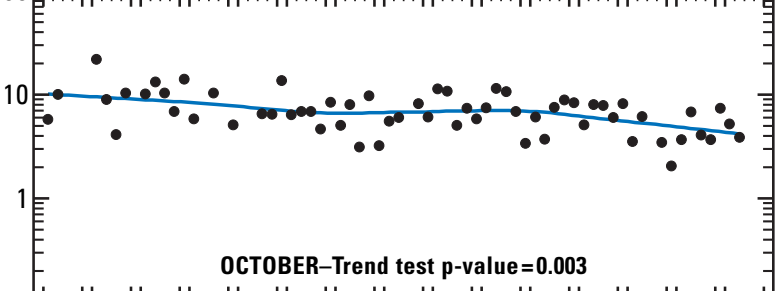

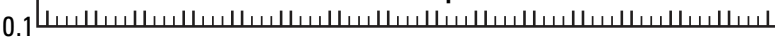

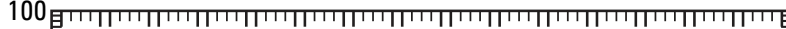

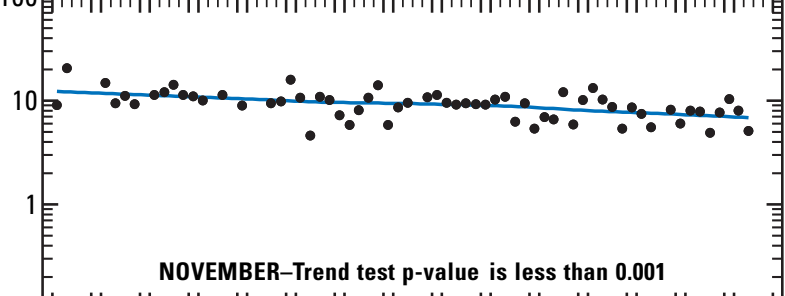

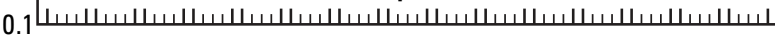

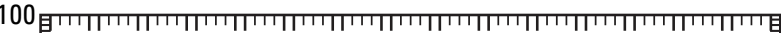

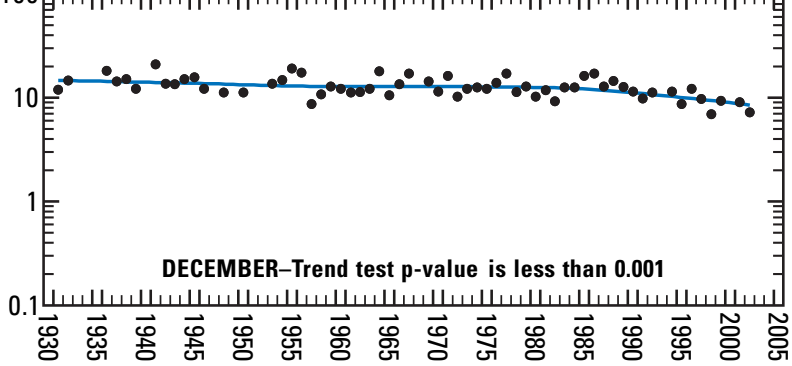

Figure 14. Continued. 
MAXIMUM DAILY MEAN FLOW
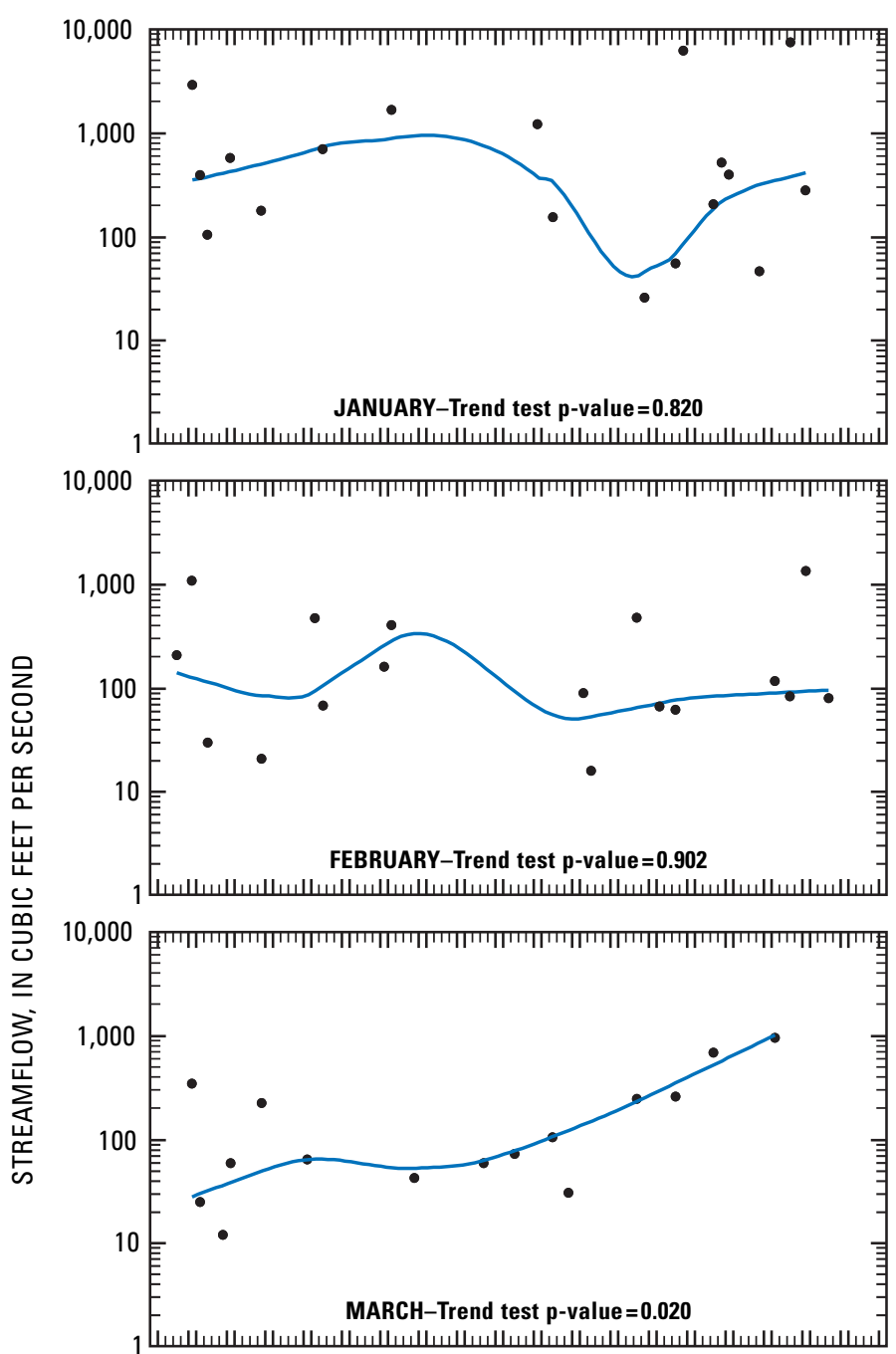

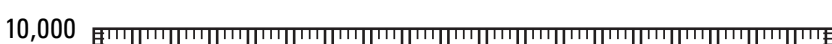

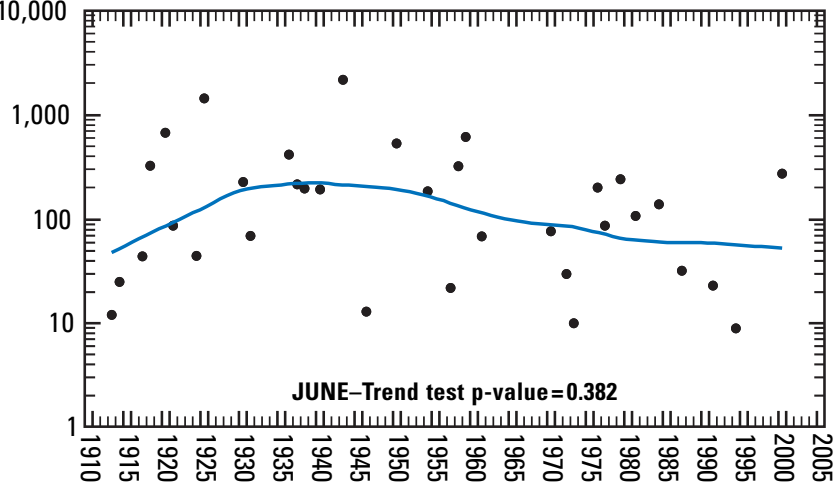

MAXIMUM DAILY MEAN FLOW
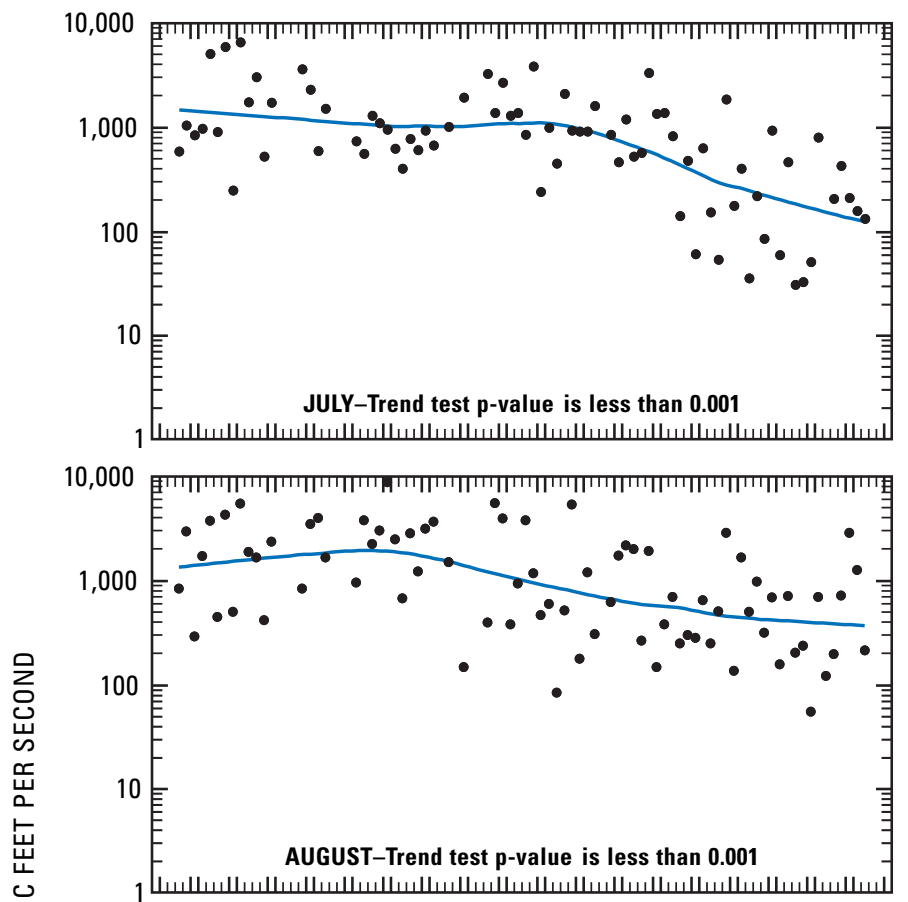

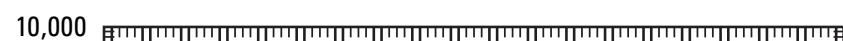
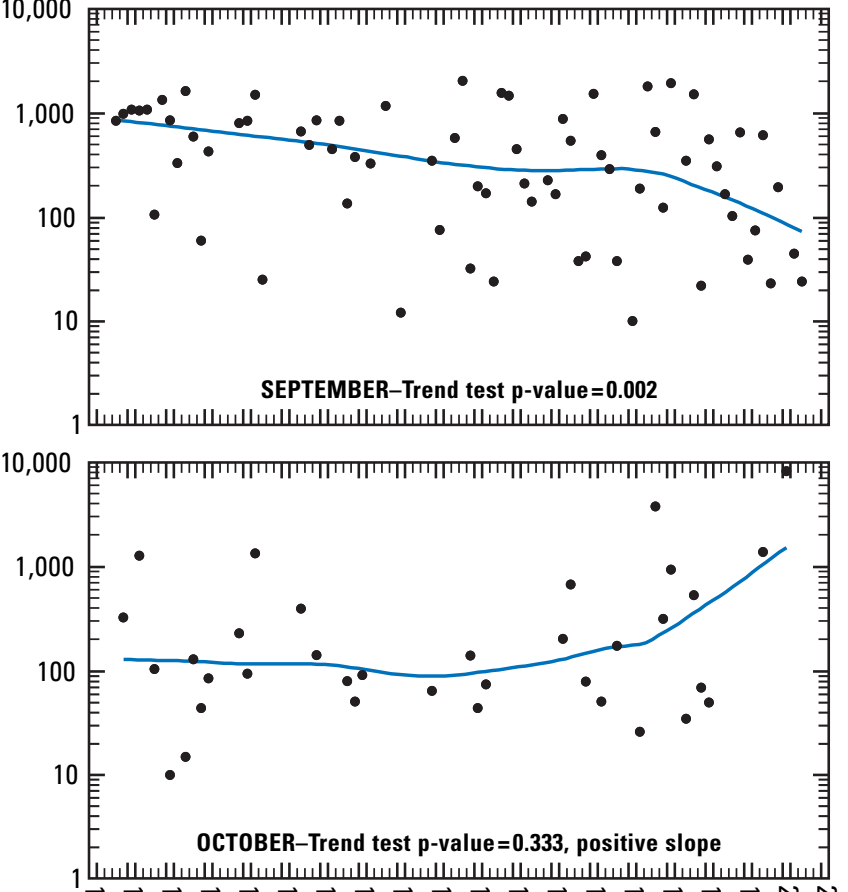

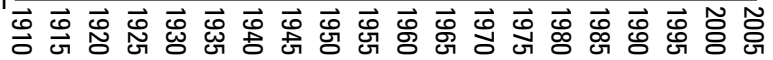

Figure 15. Trends in maximum daily storm runoff and maximum daily storm runoff adjusted for variation in precipitation, selected months, San Pedro River at Charleston, Arizona. Blue line is LOWESS fit to data. 
MAXIMUM DAILY MEAN FLOW ADJUSTED FOR VARIATION IN PRECIPITATION

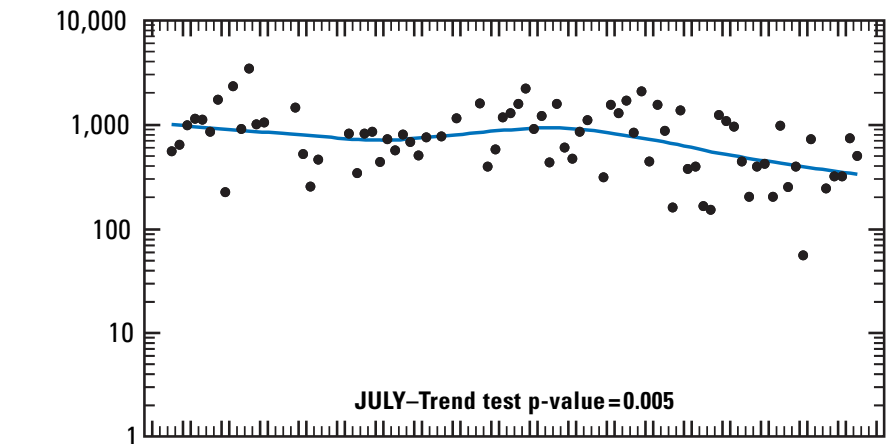

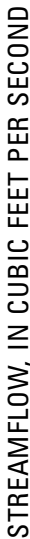

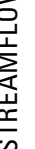

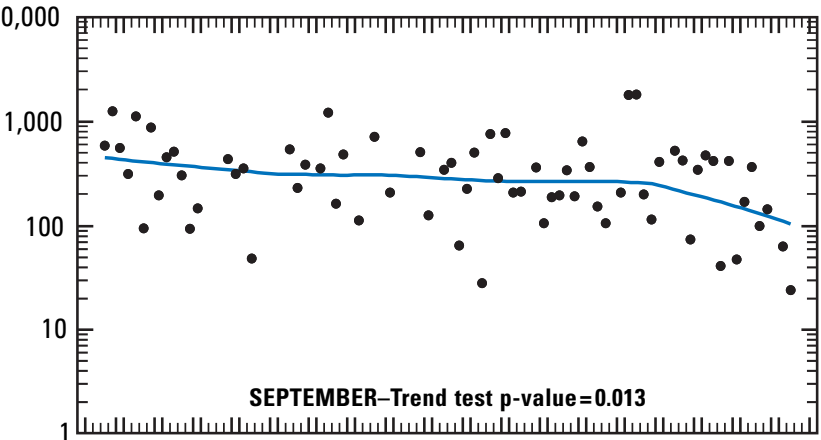

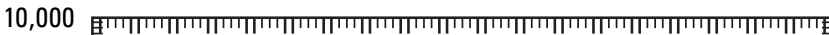

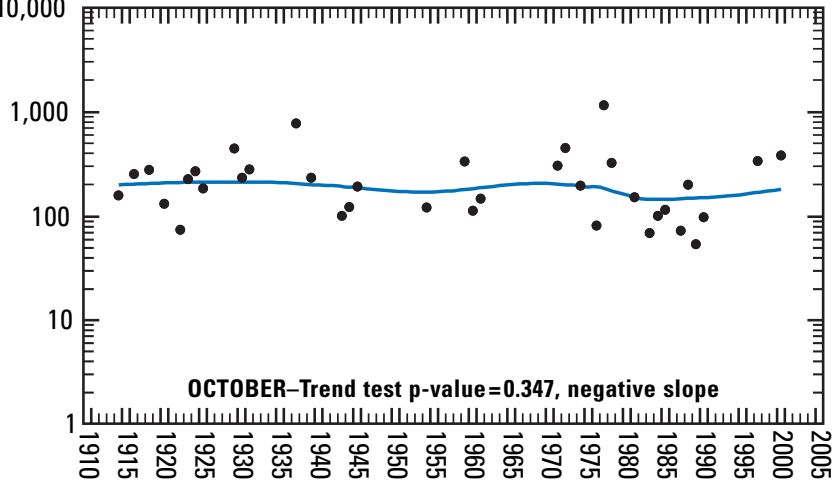

MAXIMUM DAILY MEAN FLOW

㟧

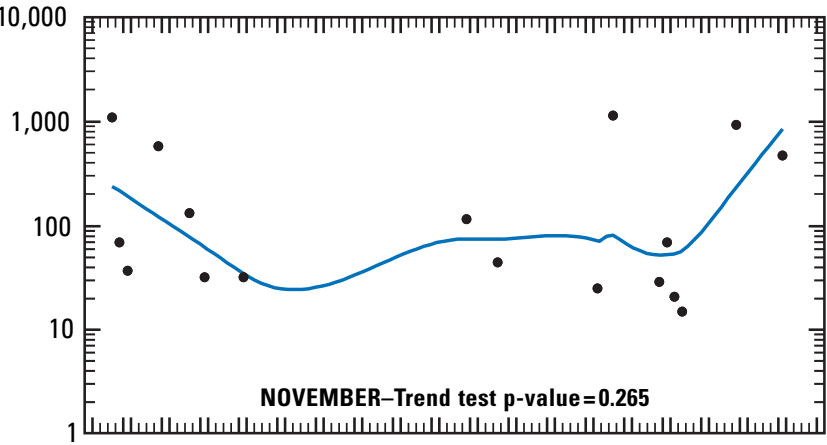

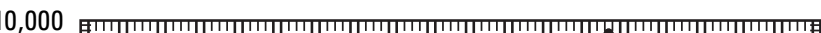

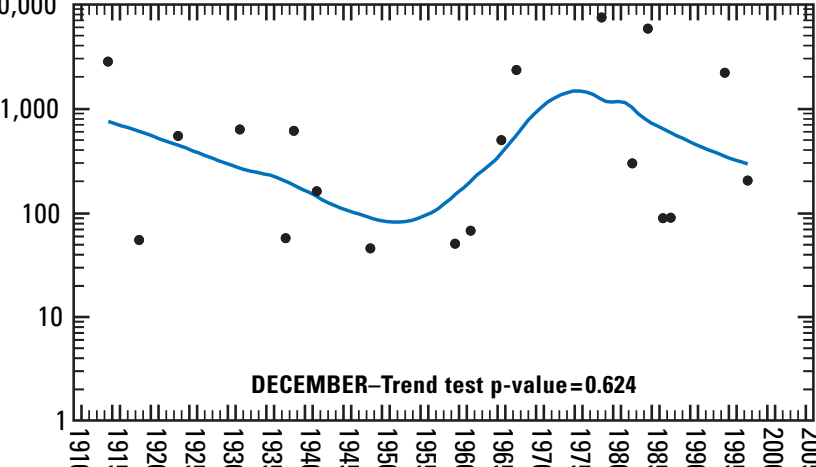

Figure 15. Continued. 


\section{Step Trends}

Step trends in streamflow caused by factors other than precipitation were determined by developing linear regression relations between precipitation and streamflow for three time periods (1913-42, 1943-76, and 1977-2002), and testing to determine if the three regression relations are significantly different. Linear least-squares regression relations were developed for monthly total streamflow (average flow) and storm runoff (maximum daily mean flow for each month). The explanatory variables (precipitation) and response variables (streamflow) were log transformed before the regression analysis.

The step-trend analysis was done using single-variable linear regression equations (one explanatory variable for precipitation). Multivariable linear equations similar to those used in the LOWESS equations (tables 14-17) were not used because (1) they did not improve the accuracy and fit and (2) the nested F-tests used for determining step trends (equation 4) would lose statistical power. Single-variable linear equations had similar $R^{2}$ values as multivariable linear equations using the same explanatory variables as the LOWESS equations. In LOWESS, multivariable equations significantly improved the fit compared to single-variable equations, but in linear least squares, single-variable equations were as good as multivariable equations. Statistical power is lost in the nested F-tests with multivariable equations by losing degrees of freedom. For example, a single variable for precipitation results in n-6 degrees of freedom for the complex model (equation 3), and n-6 degrees of freedom in the denominator of the F-test (equation 4); four variables for precipitation results in $\mathrm{n}-15$ degrees of freedom in the denominator of the F-test.

Three explanatory variables were tested for the singlevariable equations for monthly total flow: precipitation for (1) the same month as flow, (2) the same month and previous month, and (3) the same month and two previous months. The best equation was selected using the $R^{2}$ value, standard error, and distribution of residuals. This best equation was then used for the test of effects of factors other than precipitation. The linear regression is a parametric analysis, so several assumptions had to be met for the analysis to be valid. Among the more important assumptions are that (1) the relation between precipitation and streamflow must be linear, (2) outliers must not unduly influence the regression, and (3) residuals must be independent, have zero mean, have a constant variance, and follow a normal distribution (Draper and Smith, 1981, p. 141-192).

To meet the necessary assumptions, several low and high outliers had to be deleted from the analysis of monthly total flows. There were no outliers in the analysis of storm runoff. The regression relations between monthly total flows and precipitation were not linear for values of precipitation less than about 0.3 in (fig. 12). This threshold existed for all monthly flows; generally, there is minimal or no runoff (response of streamflow) when precipitation is less than $0.3 \mathrm{in}$. So, all streamflow-precipitation data pairs were deleted if the precipitation was less than 0.3 in. The resulting monthly total flows, therefore, are flows that have at least some runoff from precipitation. Some of the months also had data pairs that were high outliers where the precipitation-streamflow relation was much different from that for the majority of the data. These high outliers had to be deleted to have a linear relation between precipitation and streamflow. Results of the final linear regression analyses for all time periods are shown in appendix 2.

Storm runoff (maximum daily mean flow) was analyzed for July, August, and September. Other months did not have enough data for the analysis. Three explanatory variables were tested for the single-variable regression equations: precipitation for (1) the day of runoff, (2) the day of runoff plus one previous day, and (3) the day of runoff plus 10 previous days. Other possible combinations of days of precipitation were not tested because results of the previous LOWESS analysis of the relation between storm runoff and precipitation showed the other combinations of days were not significant as single-variable predictors of runoff. The linear regression analysis found that precipitation for the day of runoff was not a good explanatory variable for these single variable equations. Many days of runoff had zero precipitation for the same day, which resulted in low $R^{2}$ values and high standard errors of regression. The other two explanatory variables were better, although they were not strongly related to storm runoff. Results of the final linear regression analyses for all time periods are shown in appendix 2.

Factors other than precipitation caused significant step trends in total monthly streamflow from 1913 to 2002 (table 21). The step-trend results were similar to results of the previous monotonic trend analysis. The regression relations between precipitation and monthly total flows were significantly different for summer, fall, and early winter (June through December) and not significantly different for late winter and spring (February through May). The regression relations between precipitation and maximum daily storm runoff were significantly different for all the months tested: July, August, and September (table 22). Regressions for storm runoff are shown for two explanatory variables: 2 days of precipitation and 11 days of precipitation. There were slightly different results, but the overall conclusion is the same.

Linear regression relations between precipitation and monthly total flows for 3 time periods are shown for 11 months in figure 16. The regression relations for February-May are clearly similar, and the regression relations are not significantly different. The regression relations for June-December have significantly different slopes or intercepts indicating that the precipitation-streamflow relation changed over time for those months. In June-September, the precipitation-streamflow relation for the late time period (1977-2002) is significantly lower than the relations for the two earlier time periods (1913-76). Thus, for a given amount of precipitation, there was less streamflow (runoff) during 1977-2002 than during 1913-76.

Linear regression relations for three time periods for storm runoff in July, August, and September are shown in figure 17. These relations are similar to those for monthly total flow in which the regression relation (precipitation-streamflow relation) for the late time period is at a consistently lower level than the other two regression relations. 
Table 21. Results of significance tests for differences among regression relations between precipitation at Tombstone, Arizona, and monthly total streamflow for the San Pedro River at Charleston, Arizona, for three time periods

$[---$, no data; $<$, less than; $>$, greater than $]$

\begin{tabular}{|c|c|c|c|c|c|c|c|c|c|c|}
\hline \multirow[b]{3}{*}{ Month } & \multirow{3}{*}{$\begin{array}{l}\text { Months of cumulative } \\
\text { precipitation used for } \\
\text { explanatory variable }\end{array}$} & \multirow{3}{*}{$\begin{array}{l}\text { Number } \\
\text { of years } \\
\text { analyzed }\end{array}$} & \multirow{2}{*}{\multicolumn{2}{|c|}{$\begin{array}{l}\text { p-values for significance } \\
\text { tests of differences } \\
\text { among regression relations } \\
\text { for three time periods }{ }^{2}\end{array}$}} & \multicolumn{6}{|c|}{$\begin{array}{l}\text { p-values for significance tests of difference between } \\
\text { regression relations for two time periods }{ }^{2}\end{array}$} \\
\hline & & & & & \multicolumn{2}{|c|}{$\begin{array}{c}1913-42 \text { versus } \\
1943-76 \\
\end{array}$} & \multicolumn{2}{|c|}{$\begin{array}{c}1943-76 \text { versus } \\
1977-2002 \\
\end{array}$} & \multicolumn{2}{|c|}{$\begin{array}{c}1913-42 \text { versus } \\
1977-2002 \\
\end{array}$} \\
\hline & & & Slope $^{3}$ & Intercept ${ }^{4}$ & Slope $^{3}$ & Intercept ${ }^{4}$ & Slope $^{3}$ & Intercept $t^{4}$ & Slope $^{3}$ & Intercept $^{4}$ \\
\hline January $^{5}$ & --- & --- & --- & --- & --- & --- & --- & --- & --- & --- \\
\hline February & 3 & 60 & .213 & .814 & .111 & .419 & .635 & .769 & .131 & .736 \\
\hline May & 63 & 72 & .188 & .198 & .100 & .883 & .097 & .051 & .533 & .228 \\
\hline June & 1 & 36 & .451 & .008 & .560 & .138 & .537 & .072 & .212 & .004 \\
\hline July & 2 & 75 & .002 & $\left({ }^{7}\right)$ & .561 & .249 & .003 & $\left({ }^{7}\right)$ & .005 & $\left({ }^{7}\right)$ \\
\hline August & 1 & 75 & .239 & $<.001$ & .946 & .568 & .113 & .001 & .249 & $<.001$ \\
\hline September & 2 & 72 & .889 & $<.001$ & .654 & .024 & .967 & .010 & .687 & $<.001$ \\
\hline
\end{tabular}

${ }^{1}$ Precipitation for same month as streamflow and indicated number of previous months ( 1 is precipitation for same month, and 2 is precipitation for same month and one previous month).

${ }^{2}$ Data were grouped into three time periods, early is 1913-42, middle is 1943-76, and late is 1977-2002. For each time period, a linear regression analysis was made between precipitation and monthly average streamflow. A nested $\mathrm{F}$ test of simpler versus complex models was used to determine the significance of the difference among regression relations.

${ }^{3}$ Slope of regression relations.

${ }^{4}$ Intercept of regression relations.

${ }^{5}$ Linear regression relations could not be adequately fit to data.

${ }^{6}$ Months of cumulative precipitation are January, February, and March.

${ }^{7}$ Significance test for difference among regression intercepts is not valid when the slopes are significantly different.

\begin{tabular}{|l|l|l|}
\multicolumn{2}{c|}{} & p-value \\
\hline & no significant difference & $>0.10$ \\
\hline & nearly significant difference & $0.05-0.10$ \\
\hline & significant difference & $<0.05$ \\
\hline
\end{tabular}

Table 22. Results of significance tests for differences among regression relations between precipitation at Tombstone, Arizona, and maximum daily storm runoff for the San Pedro River at Charleston, Arizona, for July, August, and September, for three time periods

$[<$, less than; >, greater than $]$

\begin{tabular}{|c|c|c|c|c|c|c|c|c|c|c|}
\hline \multirow[b]{3}{*}{ Month } & \multirow{3}{*}{$\begin{array}{l}\text { Days of cumulative } \\
\text { precipitation used for } \\
\text { explanatory variable }^{1}\end{array}$} & \multirow{3}{*}{$\begin{array}{l}\text { Number } \\
\text { of years } \\
\text { analyzed }\end{array}$} & \multirow{2}{*}{\multicolumn{2}{|c|}{$\begin{array}{l}\text { p-values for significance } \\
\text { tests of differences among } \\
\text { regression relations for three } \\
\text { time periods }{ }^{2}\end{array}$}} & \multicolumn{6}{|c|}{$\begin{array}{l}\text { p-values for significance tests of difference between } \\
\text { regression relations for two time periods }\end{array}$} \\
\hline & & & & & \multicolumn{2}{|c|}{$\begin{array}{l}1913-42 \text { versus } \\
1943-76\end{array}$} & \multicolumn{2}{|c|}{$\begin{array}{l}1943-76 \text { versus } \\
1977-2002\end{array}$} & \multicolumn{2}{|c|}{$\begin{array}{l}1913-42 \text { versus } \\
1977-2002\end{array}$} \\
\hline & & & Slope $^{3}$ & Intercept $^{4}$ & Slope $^{3}$ & Intercept ${ }^{4}$ & Slope $^{3}$ & Intercept ${ }^{4}$ & Slope $^{3}$ & Intercept ${ }^{4}$ \\
\hline \multirow[t]{2}{*}{ July } & 2 & 72 & 0.845 & $<.001$ & 0.501 & 0.469 & 0.724 & $<.001$ & 0.820 & .001 \\
\hline & 11 & 72 & .504 & $<.001$ & .701 & .393 & .498 & $<.001$ & .292 & $<.001$ \\
\hline August & 11 & 69 & .195 & $<.001$ & .081 & .065 & .989 & .050 & .104 & $<.001$ \\
\hline \multirow[t]{2}{*}{ September } & 2 & 69 & .676 & .015 & .619 & .043 & .421 & .316 & .687 & .005 \\
\hline & 11 & 69 & .480 & .024 & .374 & .066 & .268 & .330 & .885 & .008 \\
\hline
\end{tabular}

'Precipitation for same day as runoff and indicated number of previous days, in inches (2 is same day and 1 previous day, 11 is same day and 10 previous days).

${ }^{2}$ Data were grouped into three time periods, early is 1913-42, middle is 1943-76, and late is 1977-2002. For each time period, a linear regression analysis was made between precipitation and monthly maximum daily mean streamflow. A nested F test of simpler versus complex models was used to determine the significance of the difference among regression relations.

${ }^{3}$ Slope of regression relations.

${ }^{4}$ Intercept of regression relations.

${ }^{5}$ Significance tests for difference among regression intercepts is not valid when the slopes are significantly different.

\begin{tabular}{|l|l|l|}
\cline { 3 - 3 } \multicolumn{2}{c|}{} & $\mathrm{p}$-value \\
\hline & no significant difference & $>0.10$ \\
\hline & nearly significant difference & $0.05-0.10$ \\
\hline & significant difference & $<0.05$ \\
\hline
\end{tabular}



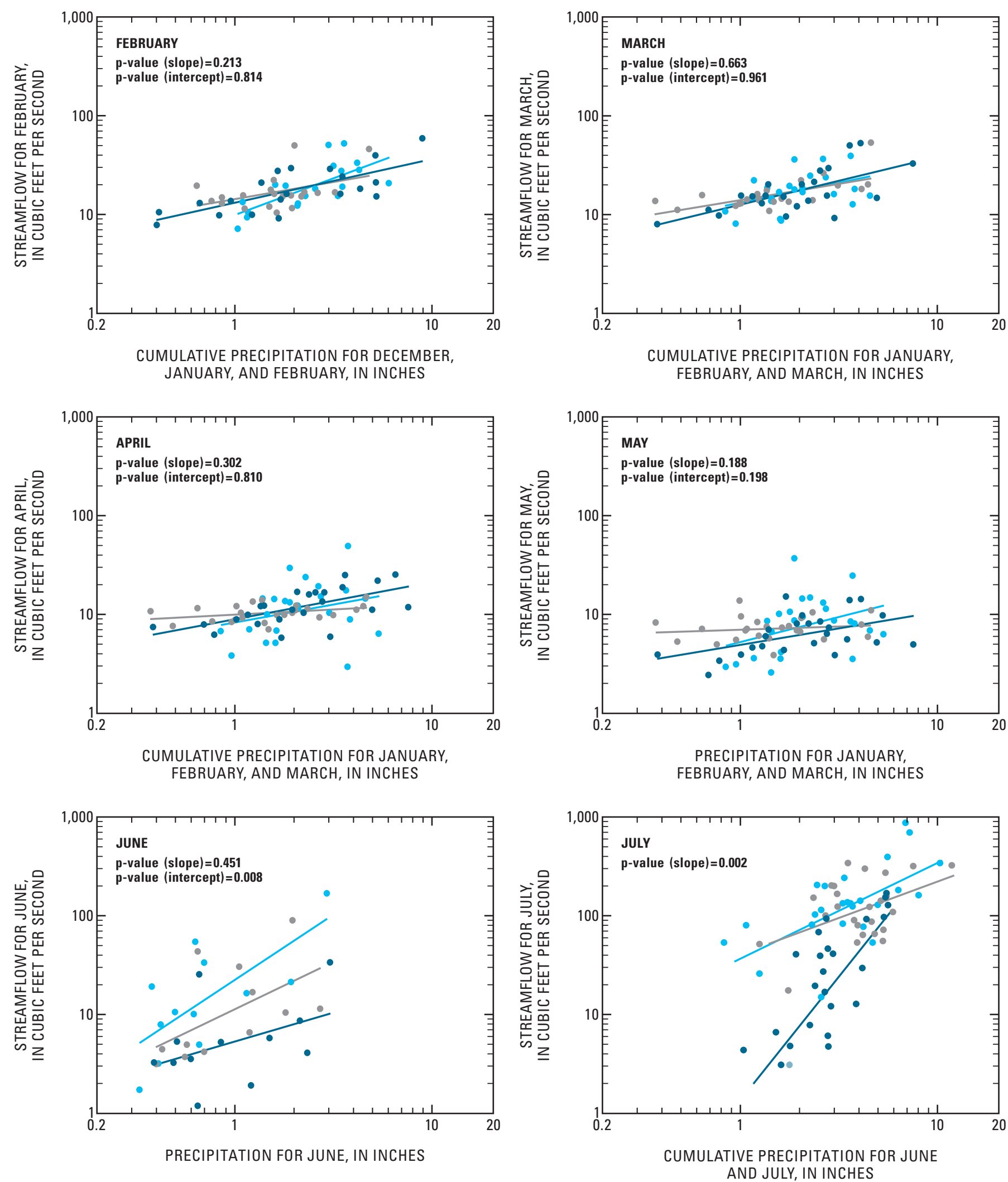

Figure 16. Regression relations between precipitation at Tombstone, Arizona, and monthly total streamflow for February through December for three time periods, San Pedro River at Charleston, Arizona. 

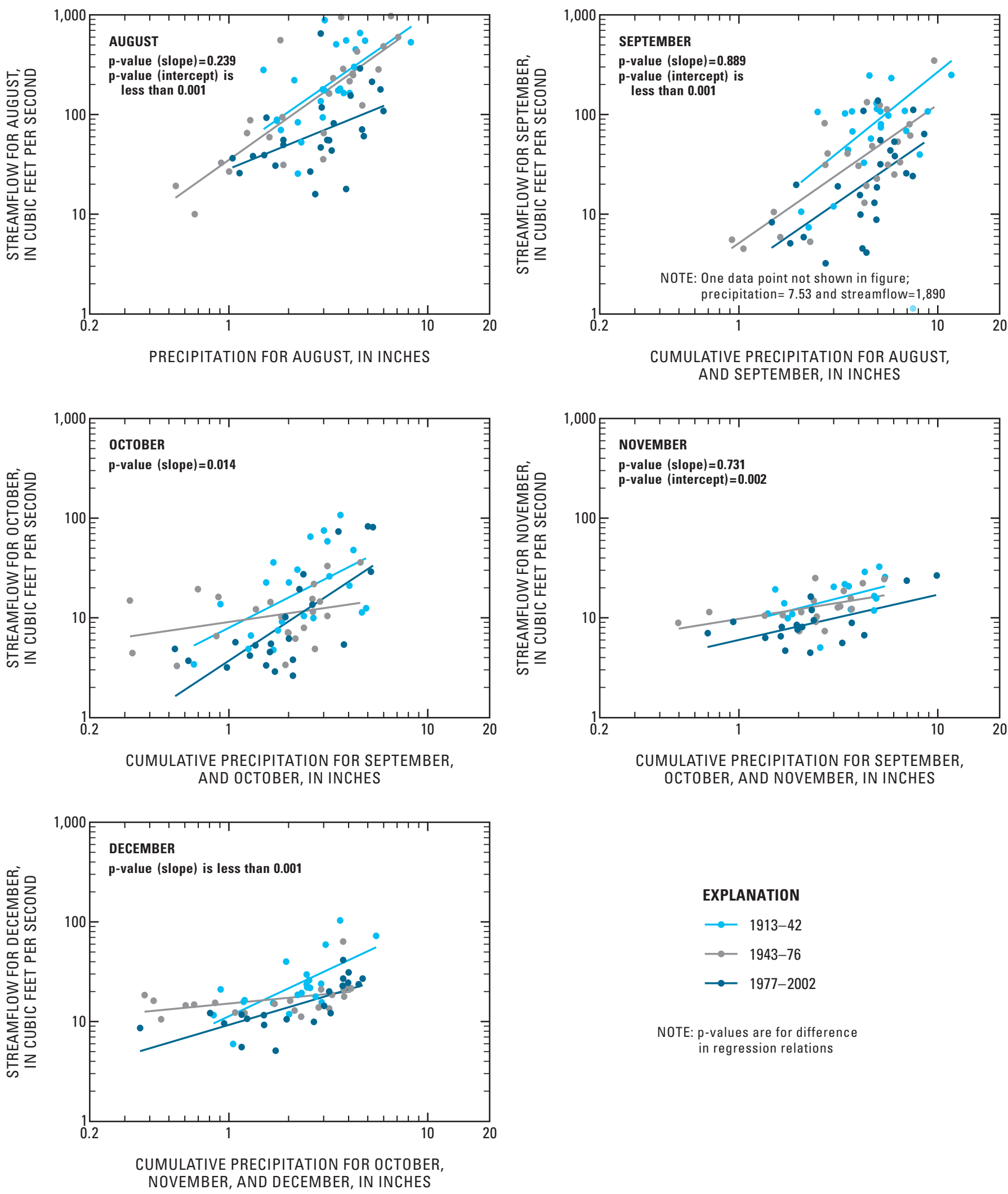

EXPLANATION

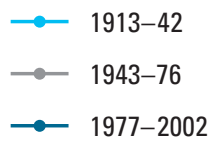

NOTE: $p$-values are for difference in regression relations

Figure 16. Continued. 


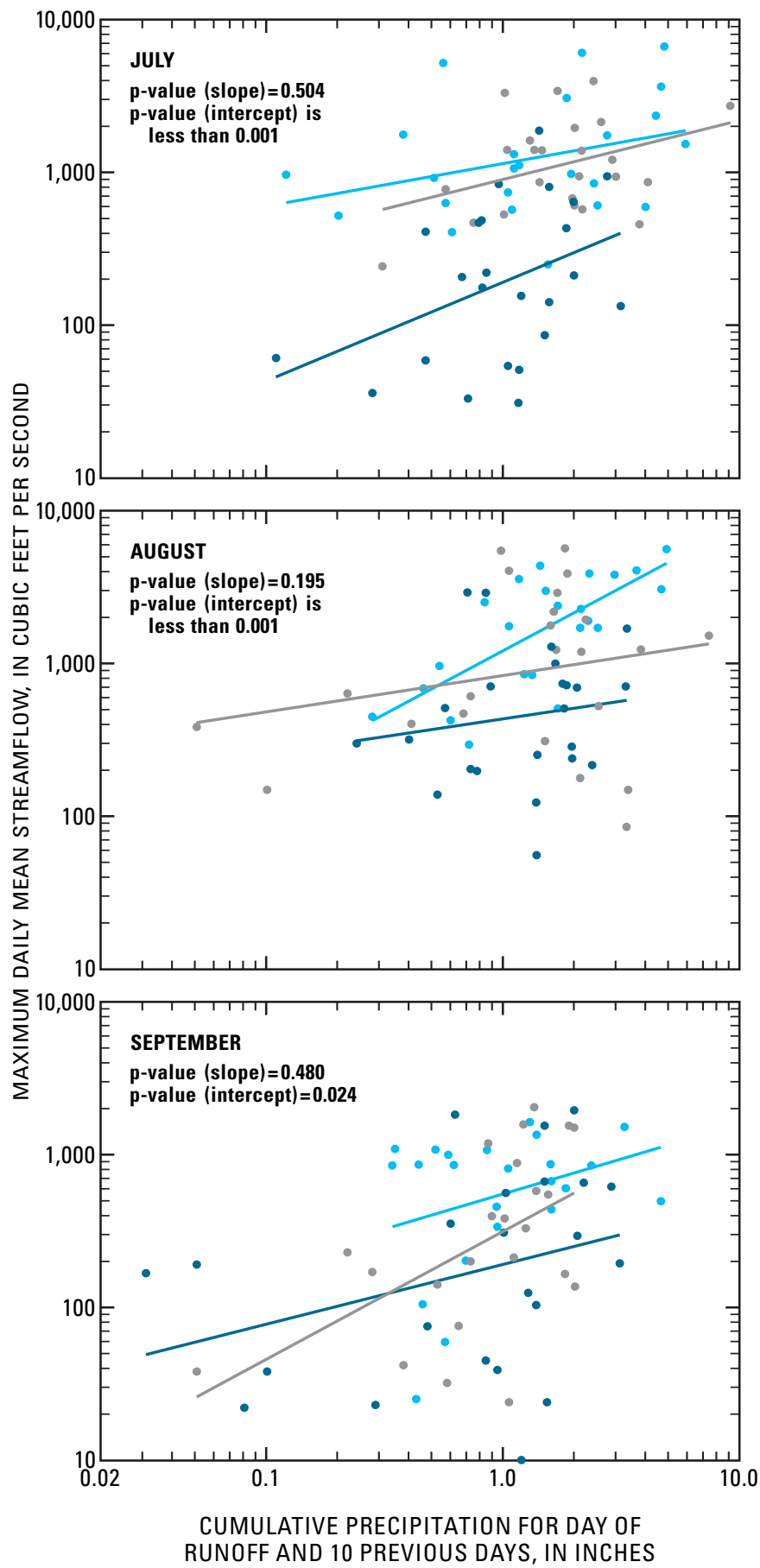

EXPLANATION

$\longrightarrow$ 1913-42

$\longrightarrow 1943-76$

$\longrightarrow 1977-2002$

NOTE: p-values are for difference in regression relations

Figure 17. Regression relations between precipitation at Tombstone, Arizona, and maximum daily storm runoff for July through September for three time periods, San Pedro River at Charleston, Arizona.

\section{Causes of Trends in Streamflow}

This study found that factors other than precipitation caused a significant decrease in streamflow of the San Pedro River (tables 18-22). The factors that caused the decrease in flows are more difficult to extract because of interaction among the different factors and because historical data on the possible factors is more qualitative than quantitative. In addition, there was a cumulative effect from the individual effects of several factors. Evaluation of the relations among components of streamflow, seasonal trends, and historical information helped to sort out the most influential factors from the least influential.

Five general factors could have caused the decreasing trends in seasonal streamflow of the San Pedro River: (1) fluctuations in precipitation; (2) fluctuations in air temperature; (3) changes in watershed characteristics, such as changes in riparian vegetation, upland vegetation, and streamchannel morphology; (4) human activities such as groundwater pumping, urbanization, construction of runoff-detention structures, and cattle ranching (grazing); and (5) changes in seasonal distribution of flow between the San Pedro River and storage in the stream bank and alluvial aquifer (table 23).

The factors causing trends were evaluated by comparing how the factors affect the stream budget (sources of inflow and components of outflow; table 8) and how the factors relate to the results of this study. Examples of factors and their relation to the stream budget include: (1) fluctuations in precipitation that have a strong effect on the two principal inflow components of streamflow (runoff and ground-water discharge) and a weak and indirect effect on the outflow components, (2) ground-water pumping that can decrease inflow from ground-water discharge and increase outflow by flow to the alluvial aquifer, and (3) changes in vegetation and associated evapotranspiration that can directly or indirectly affect almost all components. These vegetation changes can affect inflow from runoff and ground-water discharge and outflow by flow to the alluvial aquifer and transpiration.

\section{Fluctuations in Precipitation}

Fluctuations in precipitation were a major factor in the total variation in streamflow, and a decrease in precipitation likely had some influence on streamflow trends. The LOWESS regression equations showed that precipitation was significantly related to streamflow (tables 14, 16, and 17). In those equations, precipitation explained an average of 69 percent of the variation in monthly total flows, 68 percent of the variation in monthly low flows, and 68 percent of the variation in storm runoff for July, September, and October.

The portion of the decrease in streamflow caused by fluctuations or a decrease in precipitation could not be estimated with available data. Quantitative data on changes over time and on physical processes are needed for all the major factors that influenced streamflow trends (table 23), and such data were available only for precipitation and ground-water pumping. A simple comparison between the changes in monthly precipitation and streamflow, 
however, can show some useful relations. Changes in monthly average precipitation and streamflow from 1913 to 2002 were estimated by fitting a linear regression relation between precipitation and years and between log streamflow and years, and then using the change in fitted values from 1913 and 2002 as the change in average values. Streamflow was log transformed because high outliers in untransformed data result in fitted regression relations that are not representative of average values in 1913 and 2002.

From 1913 to 2002, most months had little or no changes in precipitation and large decreases in streamflow (table 24). Precipitation decreased moderately by 0.46 in. (13 percent) in August and 0.34 in. (44 percent) in November, and it decreased substantially by 1.53 in. (36 percent) in July. Streamflow decreased in 9 months, with substantial decreases of more than 70 percent in June-September and moderate decreases of between 35 and 55 percent in November-January. The decrease in precipitation in July, August, and November likely caused some of the decrease in streamflow, especially in the summer; but streamflow had much larger changes than precipitation, which indicates that other factors must have been involved.
Table 23. Factors that could cause trends in seasonal streamflow of the San Pedro River at Charleston, Arizona

Factors

1) Fluctuations in precipitation

2) Fluctuations in air temperature

3) Changes in watershed characteristics
A) Upland vegetation
B) Riparian vegetation
C) Stream-channel morphology

4) Human activities
A) Ground-water pumping
B) Urbanization
C) Construction of runoff-detention structures
D) Cattle ranching (grazing)

5) Changes in seasonal distribution of flow between the San Pedro River and storage in the stream bank and alluvial aquifer

Table 24. Changes from 1913 to 2002 in monthly average precipitation at Tombstone, Arizona, and monthly average streamflow for San Pedro River at Charleston, Arizona

\begin{tabular}{|c|c|c|c|c|c|c|c|c|}
\hline \multirow[b]{2}{*}{ Month } & \multicolumn{2}{|c|}{$\begin{array}{c}\text { Average precipitation' } \\
\text { (inches) }\end{array}$} & \multicolumn{2}{|c|}{$\begin{array}{c}\text { Change in average } \\
\text { precipitation }\end{array}$} & \multicolumn{2}{|c|}{$\begin{array}{c}\text { Average streamflow }{ }^{2} \\
\text { (acre-feet) }\end{array}$} & \multicolumn{2}{|c|}{$\begin{array}{l}\text { Change in average } \\
\text { streamflow }\end{array}$} \\
\hline & 1913 & 2002 & $\begin{array}{c}\text { Total } \\
\text { (inches) }\end{array}$ & Percent & 1913 & 2002 & $\begin{array}{c}\text { Total } \\
\text { (acre-feet) }\end{array}$ & Percent \\
\hline January & 0.78 & 0.98 & 0.20 & 26 & 1,780 & 1,160 & -620 & -35 \\
\hline February & .76 & .64 & -.12 & -16 & 1,240 & 1,310 & 70 & 6 \\
\hline April & .26 & .24 & -.02 & -8 & 640 & 760 & 120 & 19 \\
\hline May & .16 & .24 & .08 & 50 & 500 & 380 & -120 & -24 \\
\hline June & .44 & .60 & .16 & 36 & 650 & 190 & -460 & -71 \\
\hline September & 1.53 & 1.44 & -.09 & -6 & 5,420 & 1,020 & $-4,400$ & -81 \\
\hline October & .60 & 1.17 & .57 & 95 & 950 & 680 & -270 & -28 \\
\hline November & .78 & .44 & -.34 & -44 & 1,270 & 570 & -700 & -55 \\
\hline December & .94 & 1.04 & .10 & 13 & 1,620 & 1,010 & -610 & -38 \\
\hline
\end{tabular}

${ }^{1}$ Linear least squares regression was performed between year and monthly precipitation using data from 1913 to 2002 . Precipitation values for 1913 and 2002 were determined from the fitted regression equations. These fitted values are estimates of the average precipitation at the beginning and end of the record.

${ }^{2}$ The same linear-regression procedure as used for precipitation was used for streamflow, except the regression equations were fit to year and the $\log$ of streamflow. 


\section{Fluctuations in Air Temperature}

Average air temperature increased by about 2 degrees Fahrenheit during the past century (fig. 18). This temperature increase could have caused changes in vegetation in the watershed and increased the length of the growing season, which in turn could have changed the amount of evapotranspiration. There are no detailed studies of the effects of temperature change on vegetation in the San Pedro watershed. Temperature changes, if they had any effect on streamflow, would appear indirectly in the effects of changes in vegetation on streamflow. These effects of vegetation are discussed later in this section.

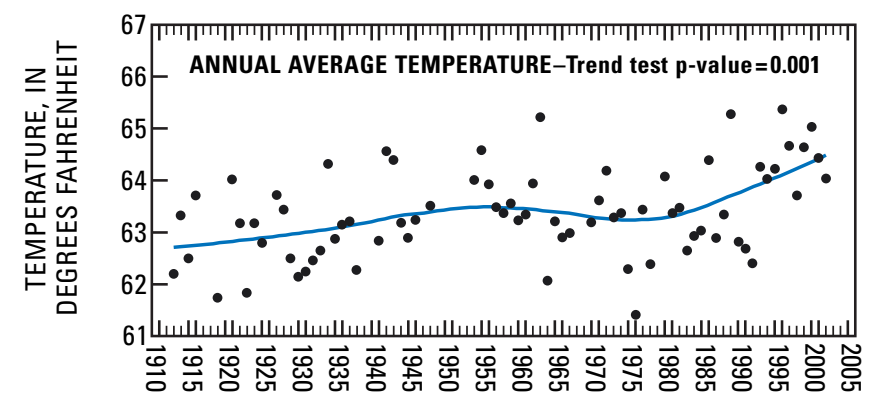

Figure 18. Annual average temperature at Tombstone, Arizona, 1913-2002. Blue line is LOWESS fit to data.

\section{Changes in Seasonal Distribution of Flow between the San Pedro River and Storage in the Stream Bank and Alluvial Aquifer}

Changes in the seasonal distribution of flow between the San Pedro River and storage in the stream bank and alluvial aquifer likely had some influence on trends in fall and winter streamflows and had little or no influence on the trend in summer streamflows. The relation between streamflow and nearby storage is complex and is strongly related to seasons and streamflow components.

Bank storage of the San Pedro River is water that is stored in alluvial material near the stream channel. During high streamflows, some of the water will flow from the river into bank storage, and when flow subsides after high flows, water will typically drain from bank storage and flow back into the river. The time period of the storage and release of storage can be as short as daily and as long as several months (seasonal). Short-term storage in the alluvial aquifer is included in this factor because the boundary between bank storage and alluvial-aquifer storage is not clearly defined. For convenience, the two types of storage are called bank storage in this discussion.

Bank storage and its effect on streamflows can be illustrated by plots of correlation coefficients between monthly total flows and total flows for 24 previous months and between monthly low flows and monthly total flows for 24 previous months (figs. 19 and 20). The correlation plot for a monthly total flow is the correlation coefficient between that month's flow and each of the 24 monthly total flows prior to that month. The correlation plots for low flows were computed between monthly low flows and the 24 prior months of total flows. A significant positive correlation between a current monthly flow and a previous month's flow is a good indication that the previous month's flow contributed some bank storage which is then released during the current month. Larger positive coefficients for a previous month indicate more influence of bank storage on the monthly flow, and a series of significant positive correlations with previous months indicates a longer and more persistent influence of bank storage.

There is a strong seasonal pattern in the correlation plots for monthly total flows (fig. 19). Winter and spring total flows are significantly correlated with about five previous months of flows. Summer total flows have little correlation with previous months because of the low spring flows where bank storage is drained each year. Fall total flows are correlated with the previous summer flows.

Monthly low flows have similar seasonal relations as those for the monthly total flows (fig. 20). Winter and spring low flows are correlated with many months of previous total flow, and summer and fall flows are correlated with only a few months of previous total flow. Monthly low flows generally are correlated with previous total flows for a longer time period than monthly total flows.

A third correlation plot was made for monthly precipitation to show that the streamflow persistence is primarily related to bank storage and is not related to persistence of monthly precipitation (fig. 21). None of the months of precipitation have a pattern of persistent significant correlations with precipitation in previous months.

It was impossible to quantitatively determine the degree of influence on streamflow trends of changes over time in the flow between the San Pedro River and bank storage. The correlation data indicated there were some seasonal differences. Bank storage has the most influence on spring and winter flows, a moderate influence on fall flows, and the least influence on summer flows (figs. 19 and 20). The number of previous months with significant correlations was about five for spring and winter flows, $2-3$ for fall flows, and 1-2 for summer flows. The average correlation coefficient for total flows and low flows for 3 previous months was 0.60 for spring and winter flows, 0.44 for fall flows, and 0.24 for summer flows.

Bank storage has a stronger influence on monthly low flows than on monthly total flows. This influence is indicated by the total number of previous months of flow with significant correlations; low flows had 70 significant months and total flows had 53 significant months (figs. 19 and 20). Bank storage also appeared to have a different duration and strength of influence on fall low flows compared to fall total flows. Fall low flows had about 4 significant previous months and fall total flows had about 2 significant previous months. The average correlation coefficient for 3 previous months was 0.53 for fall low flows and 0.36 for fall total flows. 

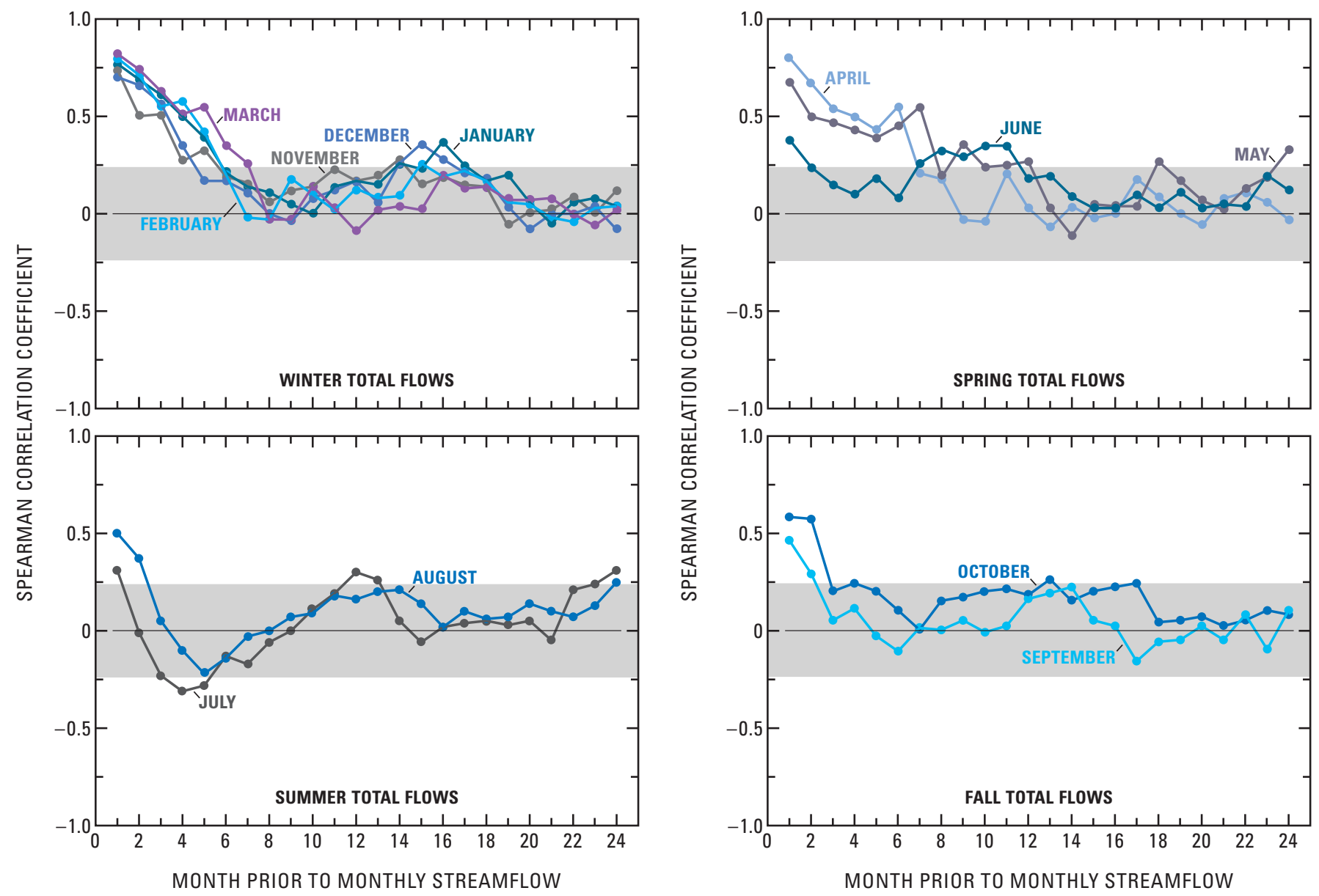

EXPLANATION

Correlations not significant at 5 percent level

Figure 19. Correlations between monthly total streamflows and total streamflows for 24 previous months, San Pedro River at Charleston, Arizona, 1913-2002. 

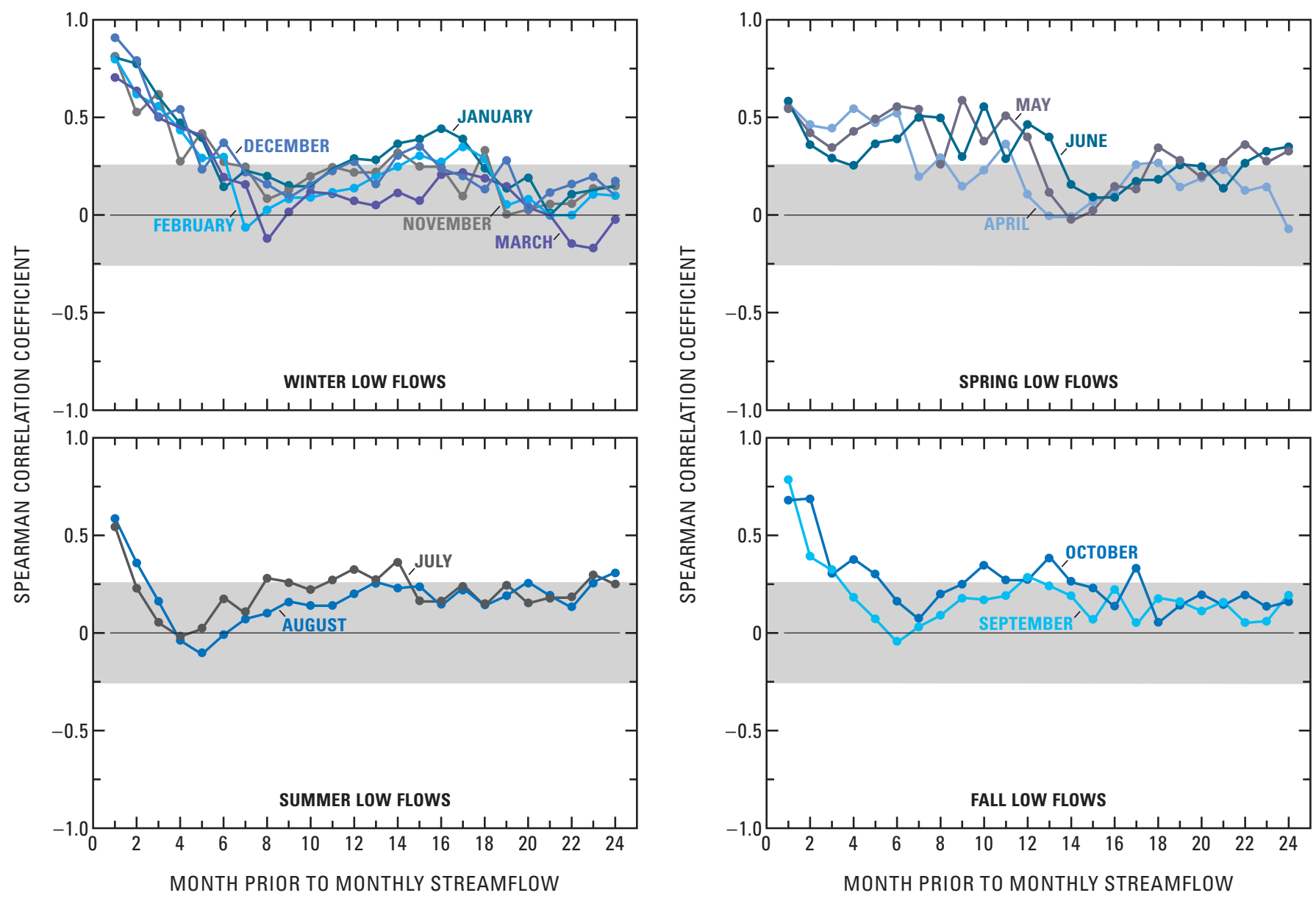

EXPLANATION

Correlations not significant at 5 percent level

Figure 20. Correlations between monthly low flows and total streamflows for 24 previous months, San Pedro River at Charleston, Arizona, 1931-2002. 

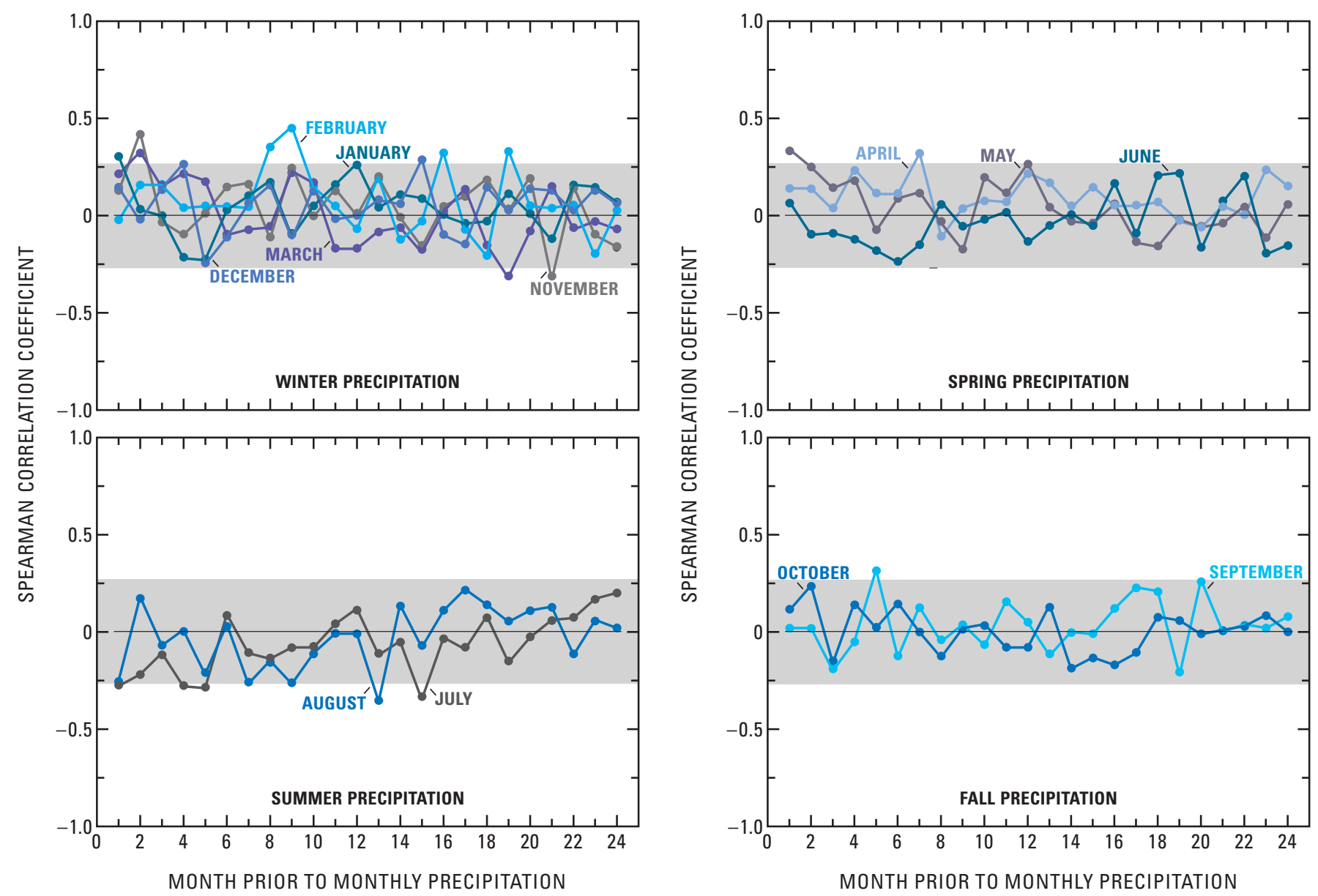

EXPLANATION

Correlations not significant at 5 percent level

Figure 21. Correlations between monthly precipitation and precipitation for 24 previous months, Tombstone, Arizona, 1913-2002. 
The correlations among bank storage, seasons, low flows, and total flows (figs. 19 and 20) provide information that needs to be considered in analyzing trends of monthly and seasonal flows. The long duration and strong influence of bank storage on winter and spring flows indicate that trends in previous months (up to about 5) could have affected trends in winter and spring flows. The short duration and generally weak influence of bank storage on summer flows indicate that summer flows likely were not affected by trends in any other seasonal flow. The short but strong influence of bank storage on fall flows, especially low flows, indicates that trends in summer flows could have affected trends in fall flows.

The seasonal difference in flow volumes is another streamflow characteristic that needs to be considered in analyzing the influence of bank storage on streamflow trends. Summer and early fall flows provide most of the annual volume of streamflow (fig. 5); flows during July through September were 70 percent of the annual flow in the predevelopment period. A large decrease in this summer total flow over time would affect trends in fall and early winter flows. As summer flows decrease, fall and early winter flows would also decrease because there would be less summer bank storage and less release of that bank storage in the fall and early winter. In the fall and winter, flows generally are low to moderate in magnitude (fig. 5) and large runoff events occur infrequently. Thus, only trends in the large runoff events would likely have any influence on subsequent seasonal flows. In the spring, flows are low in magnitude and runoff occurs infrequently. Thus, trends in spring flows would have no influence on subsequent summer flows. Bank storage also drains during the spring, so summer flows start out each year with little or no influence from bank storage.

The trends determined for adjusted streamflows (streamflow with effects of precipitation removed) account for some of the effects of changes in bank storage. All the LOWESS equations used to remove effects of precipitation from streamflow had precipitation in previous months as explanatory variables (table 15). Changes in previous month's precipitation over time would likely be correlated with changes in bank storage over time. Thus, some of the effects of changes in bank storage have been removed from the adjusted streamflows.

In summary, changes in bank storage over time had a minimal effect on trends in summer flows, so the causes of decreasing trends in summer flows could have been fluctuations in precipitation and temperature, changes in watershed characteristics, or human activities. Parts of the decreasing trend in fall and early winter flows, however, were likely caused by the decreasing bank storage from the decreasing trend in summer total flows. Understanding the causes of decreasing summer total flows is, therefore, important to understanding the causes of the overall decrease in annual flows and the causes of the decrease in fall and early winter flows.

\section{Changes in Watershed Characteristics}

Riparian and upland vegetation.-Changes in upland and riparian vegetation were likely major factors in the decreasing trends in total streamflow and low flow of the San Pedro River. Change in vegetation was identified as important, but this study could not distinguish if change in upland vegetation or riparian vegetation was more important. The evidence that vegetation was a major factor is: (1) that summer streamflow trends were different from winter streamflow trends, (2) that riparian and upland vegetation changed substantially during the 20th century, and (3) that evapotranspiration dominates the watershed budget, and small changes in evapotranspiration could cause large changes in streamflow.

A seasonal difference in significant trends in adjusted streamflow supports vegetation as a major cause of decreasing streamflow, because significant trends were found during the months of highest transpiration and significant trends were not found during months of low transpiration. Factors other than precipitation caused significant decreasing trends in total flows and low flows during summer and early fall (June-September) and did not cause significant trends in most late winter flows (January-March; tables 18-20). Significant decreasing trends were also determined for months of moderate to low transpiration (October-December), but part of those trends can be explained by the decreasing water available from bank storage as summer total flows decreased over time.

Data on vegetation changes in the watershed during the 20th century also support vegetation as a major cause of the decrease in streamflow. Two studies found large changes in upland vegetation during the 20th century (Kepner and Edmonds, 2002; Turner and others, 2003). Kepner and Edmonds (2002) used satellite data to determine changes in vegetation from 1973 to 1997 for the San Pedro River watershed above Redington. These changes should be similar to the changes in the watershed above Charleston. From 1973 to 1997 , the area of grasslands decreased by 16 percent, the area of desert scrub decreased by 22 percent, and the area of mesquite woodland increased by 400 percent. Quantitative data are not available for changes before 1970, but repeat photographs in the late 1800s, early 1960s, and 1994 (Turner and others, 2003) show large changes from grasslands to woody plants, primarily mesquite.

The changes in upland vegetation from grasslands to woody plants can affect high flows (runoff) and low flows (ground-water discharge). The changes can decrease runoff by (1) increasing interception of precipitation, which would increase evaporation from intercepted precipitation, 
and by (2) increasing transpiration, which would decrease soil-moisture storage and increase the amount of storage space available for infiltration of precipitation. Increased transpiration from the upland vegetation would also ultimately decrease low flows because ground-water recharge and discharge would be decreased. Measurements of water use by vegetation in the San Pedro River flood plain just east of Sierra Vista showed larger water-use rates for mesquite than for grasslands (Scott and others, 2000). Water use (evaporation and transpiration) from grasslands was about equal to precipitation, and water use from mesquite woodland was about 1.5 times the precipitation. Almost all the water use at those study sites in a flood plain was from soils and not from ground water, so the results can apply to the upland vegetation of the watershed where ground water is not accessible by plants.

Riparian vegetation near the San Pedro River generally increased during the 20th century in a pattern of about three shifts or step changes. The primary types of trees were Fremont cottonwood, mesquite, Goodding willow, and saltcedar. Before about 1900, the stream valley was mostly marshland and there was only a small riparian forest; from 1900 to the 1930s, riparian vegetation increased slowly but was still limited in areal extent and density; from the 1930s to 1960, vegetation increased at a rapid rate and approximately doubled in area; and after 1960, the areal extent and density increased at a slow rate or stabilized, but there were many changes in the relative abundance of different species (Lacey and others, 1975; Hereford, 1993; Stromberg, 1998; Rojo and others, 1999).

Changes in riparian vegetation on the stream bank or nearby flood plain can affect low flows and high flows. Increased riparian vegetation or change to a species that uses more water can decrease low flows by (1) intercepting and removing ground water that would have discharged to the river, (2) increasing the amount of water that is transpired from the river (the water moves from the river through soils and into plant roots), and (3) lowering the ground-water level near the river during the growing season, which creates a larger storage volume for downward seepage and loss of streamflow. Increased riparian vegetation can decrease high flows by lowering the ground-water level and increasing seepage losses.

Another reason that vegetation change is likely an important factor in the decrease in streamflow is that small changes in watershed vegetation could result in large changes in streamflow; evapotranspiration accounts for about 90 percent of the precipitation that falls on the watershed (table 6).

Stream-channel morphology.-Changes in streamchannel morphology likely had some influence on streamflow trends. The channel migrated laterally and increased its sinuosity and flood plain area during the 20th century (Hereford, 1993). There were two distinct periods of geomorphic activity. Before 1955, the stream channel was active and it widened substantially by lateral migration and expansion of meanders. After 1955, the stream channel was fairly stable; lateral and vertical changes were small.

The increased sinuosity and flood plain area could cause high flows to decrease by increased attenuation, infiltration, and storage of water. Those changes could cause low flows to decrease by increased flow to more available bank storage and indirectly by increased riparian vegetation in a larger floodplain. The changes could also cause low flows to increase: high flows in a more sinuous channel and a larger floodplain would lose more water to bank storage, which would then drain back to the river in subsequent months and increase low flows.

Changes in channel morphology probably had some influence on trends in high flows because there is a physical explanation for how the changes could have caused decreases in flows. The influence probably was not major, however, because the changes in morphology should have had the same effect on all seasonal total flows, and trends in seasonal total flows were different (tables 18, 20, and 21). Changes in morphology were likely a minor factor in low-flow trends because the changes could have increased and decreased low flows and thus balanced out any potential effect on trends.

\section{Human Activities}

Ground-water pumping.-Results of this study indicate that ground-water pumping had a mixed influence on streamflow trends at Charleston; the degree of influence depends on the location of pumping wells and the amount of pumping. Statistical analyses indicate that seasonal pumping from wells near the river for irrigation in the spring and summer was a major factor in the decreasing trends in low flows and that year-round pumping from the regional aquifer in wells away from the river was not a major factor.

Ground-water pumping from the regional basinfill aquifer and floodplain alluvial aquifer is considered a possible cause of the decreasing streamflows because pumping increased substantially during the second half of the 20th century (fig. 22). Total pumping in the Sierra Vista subwatershed in Arizona and the San Pedro Basin in Mexico (fig. 3) was generally less than 2,000 acre-ft/yr prior to 1940. There was pumping for mining activities near Tombstone during the first decade of the 20th century, but Tombstone is downstream of Charleston, and the pumping should have had a minimal effect on streamflow at Charleston from 1913 to 2002. Total pumping increased steadily from 3,600 acre-ft/yr in 1940 to about 28,000 acre-ft/yr in the 1970s and increased at a more rapid rate to about 53,000 acre-ft/yr in 2002 (Corell and others, 1996; Consultores en Agua Subterranea S.A., 2000; De Aguinaga, 2002; Arizona Department of Water Resources, 2005). 


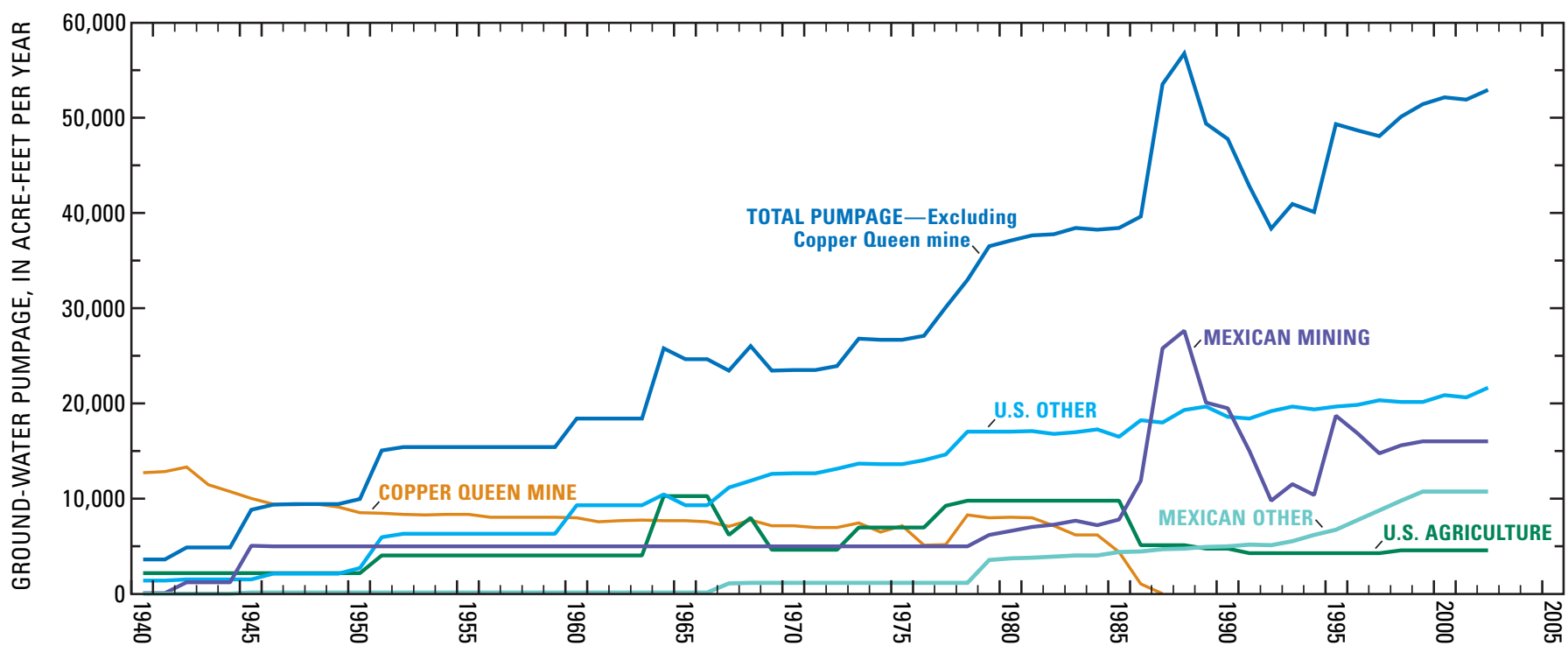

Figure 22. Ground-water pumpage in the Upper San Pedro River Basin, Sierra Vista subwatershed, Arizona and Sonora, Mexico, 1940-2002.

In the United States, pumping was for agriculture, public supply, domestic supply, and a military base (Fort Huachuca). After 1950, most of the pumping in the United States was (1) for nonagricultural uses, (2) from the regional aquifer away from the San Pedro River near Sierra Vista and Fort Huachuca, and (3) distributed year round. The agricultural pumping in the United States was near the river and most was in the spring and summer. There were three distinct periods of agricultural pumping; average rates were about 3,200 acre-ft/yr during 1940-63, 8,100 acre-ft/yr during 1964-85, and 4,600 acre-ft/yr during 1986-2002 (fig. 22).

In Mexico, pumping was for mining activities, agriculture, public supply, and domestic supply. Pumping for mining activities mostly was year round and steady at about 5,100 acre-ft/yr from 1945 to 1980, and then it fluctuated and increased to about 16,000 acre-ft/yr in 2002. Agricultural pumping, mostly near the river and during spring and summer, accounted for about 90 percent of the other pumping (nonmine) in Mexico (De Aguinaga, 2002). The agricultural pumping was less than about 1,000 acre-ft/yr before the late 1970s and increased steadily from about 3,700 acre-ft/yr in 1980 to 10,700 acre-ft/yr in 2002 (fig. 22).

From 1906 to 1986, ground water was pumped to dewater the Copper Queen mine near Bisbee, Ariz. (fig. 22). This pumping was assumed to have a minimal effect on discharge to the San Pedro River from the regional basinfill aquifer because (1) the pumping was from ground water in bedrock, (2) the pumping was near a surface-water and ground-water divide with the adjacent basin to the east, and (3) most of the pumped water was transported to evaporation ponds and for irrigation south of Bisbee. Seepage from the evaporation ponds and return flow from irrigation added some artificial recharge to the basin-fill aquifer (Southwest GroundWater Consultants, 2004). The pumping from the Copper Queen mine was, therefore, not considered as a possible factor in the decreasing streamflow trends and was not added to the total pumping discussed for the study area and shown in figure 22 .

Ground-water pumping can decrease low flows or total flows in streams by three principal mechanisms that are related to a decrease in ground-water levels: (1) in stream reaches that receive ground-water discharge (gaining stream), the hydraulic gradient from the aquifer to the stream is decreased, and the decreased gradient results in a decrease in ground-water discharge to the stream; (2) in stream reaches where water flows from the stream to the aquifer and there is no unsaturated material between the streambed and the water table (losing stream), the hydraulic gradient from the stream to the aquifer is increased, and the increased gradient results in increased flow of water from the stream to the aquifer; and (3) a combination of mechanisms 1 and 2 in which the hydraulic gradient and flow direction between the aquifer and stream is reversed-initially water moves from the aquifer to the stream, then it changes so water moves from the stream to the aquifer (Alley and others, 1999). In addition to the above three mechanisms that act mostly on low flows, ground-water pumping can also decrease total flows during moderate and high flows. When ground-water levels are lowered near a stream, the storage space in unsaturated material is increased, which allows more water to infiltrate the ground and be lost from the stream. 
Many previous studies have analyzed the groundwater system and its interaction with the upper San Pedro River during the past 40-60 years, and all concluded that ground-water pumping caused a decrease in annual base flow of the San Pedro River (table 25). Two ground-water models estimated an average decrease in base flow of 49 percent at Charleston (Vionnett and Maddock, 1992; Goode and Maddock, 2000), and two models estimated an average decrease in base flow of 40 percent at Fairbank, Ariz. (Freethey, 1982; Correll and others, 1996). Separate analyses of streamflow data estimated a decrease in base flow of 49 percent at Charleston (Corell and others, 1996) and 22 percent at Fairbank (Rojo and others, 1999).

The results of this statistical study appear to be different from results of the previous ground-water model simulations. This study indicates that seasonal pumping from wells near the river was a major factor in the decrease in low flows (base flows) at Charleston, but year-round regional pumping was not a major factor. If regional pumping had caused a trend, the pumping should have affected low flows for all months of the year, but factors other than precipitation did not cause significant trends in low flows for January, February, March, and May (table 19). The influence of seasonal pumping near the river fits into this study's results because most of that pumping is in the summer, and pumping during the summer could cause a decrease in ground-water discharge in the summer and no decrease in the winter. Previous ground-water models simulated all pumping (near-stream and regional) in annual time periods; thus, the simulations could not distinguish between effects of seasonal nearstream pumping and effects of year-round regional pumping. A decrease in annual base flow could result from a large decrease in base flow during the spring, summer, and fall, and no decrease in base flow during the winter. It is possible, therefore, that much of the simulated decreases in annual base flow at Charleston were from seasonal pumping of nearstream wells and that results of this study are similar to results of previous models.

Seasonal near-stream ground-water pumping has a similar effect on base flow as transpiration from riparian vegetation. Both factors can decrease base flow by removing ground water and causing a decrease in the hydraulic gradient between ground water and the stream, and both factors can cause a base-flow decrease in the summer and no decrease in the winter. Thus, it was not possible to distinguish between the effects of these two factors using a statistical analysis of the available data on precipitation, streamflow, near-stream pumping, and riparian vegetation.

Table 25. Changes in estimated annual base flow for San Pedro River from predevelopment period to 1977-2002, previous studies, and this study

\begin{tabular}{|c|c|c|c|c|c|c|c|}
\hline \multirow[b]{2}{*}{ Source } & \multirow[b]{2}{*}{$\begin{array}{l}\text { Method of } \\
\text { estimating base flow }\end{array}$} & \multirow{2}{*}{$\begin{array}{l}\text { Location } \\
\text { of estimated } \\
\text { base flow }\end{array}$} & \multirow{2}{*}{$\begin{array}{l}\text { Last time period } \\
\text { for estimated } \\
\text { base flow }\end{array}$} & \multicolumn{2}{|c|}{$\begin{array}{l}\text { Base flow in acre-feet per year } \\
\text { and cubic feet per second }{ }^{1}\end{array}$} & \multicolumn{2}{|l|}{ Change in flow } \\
\hline & & & & Predevelopment $^{2}$ & $\begin{array}{l}\text { Last } \\
\text { time period }\end{array}$ & $\begin{array}{c}\text { (acre-feet and } \\
\text { cubic feet per second) }\end{array}$ & (percent) \\
\hline $\begin{array}{l}\text { Vionnett and Maddock } \\
\text { (1992) }\end{array}$ & Ground-water model & Charleston & 1988 & $\begin{array}{l}8,300 \\
\quad(11.5)\end{array}$ & $\begin{array}{l}2,900 \\
(4.0)\end{array}$ & $\begin{array}{l}-5,400 \\
(-7.5)\end{array}$ & -65 \\
\hline $\begin{array}{l}\text { Corell and others } \\
\text { (1996) }\end{array}$ & $\begin{array}{l}\text { Base-flow analysis of } \\
\text { streamflow data }\end{array}$ & Charleston & 1985-1991 & $\begin{array}{l}9,500 \\
\quad(13.1)\end{array}$ & $\begin{array}{l}4,800 \\
(6.6)\end{array}$ & $\begin{array}{l}-4,700 \\
(-6.5)\end{array}$ & -49 \\
\hline $\begin{array}{l}\text { Goode and Maddock } \\
\text { (2000) }\end{array}$ & Ground-water model & Charleston & 1997 & $\begin{array}{l}9,600 \\
\quad(13.2)\end{array}$ & $\begin{array}{l}6,400 \\
(8.9)\end{array}$ & $\begin{array}{l}-3,200 \\
(-4.3)\end{array}$ & -33 \\
\hline This study & $\begin{array}{l}\text { Measured 3-day } \\
\text { monthly low flows }\end{array}$ & Charleston & 1991-2002 & $\begin{array}{l}7,900 \\
(10.9)\end{array}$ & $\begin{array}{l}4,300 \\
(5.9)\end{array}$ & $\begin{array}{l}-3,600 \\
(-5.0)\end{array}$ & -46 \\
\hline Freethey (1982) & Ground-water model & Fairbank & 1977 & $\begin{array}{l}7,500 \\
\quad(10.4)\end{array}$ & $\begin{array}{l}4,500 \\
(6.2)\end{array}$ & $\begin{array}{l}-3,000 \\
(-4.2)\end{array}$ & -40 \\
\hline $\begin{array}{l}\text { Corell and others } \\
\text { (1996) }\end{array}$ & Ground-water model & Fairbank & 1990 & $\begin{array}{l}9,500 \\
\quad(13.1)\end{array}$ & $\begin{array}{l}5,700 \\
(7.9)\end{array}$ & $\begin{array}{l}-3,800 \\
(-5.2)\end{array}$ & -40 \\
\hline $\begin{array}{l}\text { Rojo and others } \\
\qquad(1999)\end{array}$ & $\begin{array}{l}\text { Previous models and } \\
\text { statistical analysis }\end{array}$ & Fairbank & 1990 & $\begin{array}{l}9,500 \\
\quad(13.1)\end{array}$ & $\begin{array}{l}7,400 \\
(10.2)\end{array}$ & $\begin{array}{l}-2,100 \\
(-2.9)\end{array}$ & -22 \\
\hline
\end{tabular}

${ }^{1}$ Base flow is discharge of the San Pedro River during times of no runoff. It is ground-water discharge minus evapotranspiration from nearby riparian vegetation.

${ }^{2}$ Predevelopment period is prior to 1940 . 
If the conclusion about year-round regional pumping is incorrect (not a major factor), the most likely reason is that there was some factor that caused an increase in winter low flows that balanced out a decrease caused by regional pumping. For example, an increase in winter flows of $3.0 \mathrm{ft}^{3} / \mathrm{s}$ from 1931 to 2002 could have balanced out a decrease in winter flows of $3.0 \mathrm{ft}^{3} / \mathrm{s}$ caused by regional pumping.

Urbanization and runoff-detention basins in Sierra Vista are potential factors that could have caused this balancing effect by increasing ground-water recharge and resulting discharge to the San Pedro River (see next section), but this seems unlikely because most of the increased discharge to the river would have been in the 1980s, 1990s, or later. Urbanization would not have caused an appreciable increase in recharge until the size of Sierra Vista increased beyond a small town; the population increased from 6,700 in 1970 to 25,000 in 1980 (City of Sierra Vista, 2005). Runoff-detention basins substantial enough to create appreciable recharge were not constructed until the late 1980s (Upper San Pedro Partnership, 2002).

To evaluate this study's conclusion about regional pumping, trends in precipitation-adjusted low flows were evaluated for 1931 to 1980 , which is before any potential balancing effect from urbanization or runoff-detention structures in Sierra Vista. The study conclusion was supported, because there were no significant trends in adjusted low flows for January, February, March, and May during 1931-80.

The conclusion from this study that year-round regional ground-water pumping was not a major influence on baseflow trends is only for trends in low flows from 1931 to 2002 at Charleston. Regional U.S. and Mexico pumping could affect streamflow at Charleston in the future because regional ground-water pumping often has a delayed effect on streamflows. Ground-water pumping from wells far from a stream may not affect streamflows for years, decades, or longer (Alley and others, 1999).

Urbanization, cattle ranching (grazing), and runoffdetention structures.-Urbanization, cattle grazing, and runoff-detention structures probably had some influence on streamflow trends. These three factors typically have opposite effects on low flows compared to high flows. Urbanization and cattle grazing usually cause an increase in high flow and a decrease in low flow, and runoff-detention structures usually cause a decrease in high flow and an increase in low flow.

Urbanization typically increases high flows by causing more runoff from increased impervious areas, and it typically decreases low flows by decreasing infiltration of precipitation, ground-water recharge, and eventually ground-water discharge. Urbanization in Sierra Vista probably caused a small increase in high flows of the San Pedro River after the 1970s when the population and corresponding impervious area increased appreciably (City of Sierra Vista, 2005). The effect of urbanization in Sierra Vista on low flows appears to be different from the typical effect of urbanization in more humid areas. Some preliminary studies indicate that urbanization may increase ground-water recharge, which would eventually result in an increase in low flow (GeoSystems Analysis, 2004; David C. Goodrich, U.S. Department of AgricultureAgricultural Research Service, written commun., 2002). The increased runoff from urban impervious areas is concentrated and diverted to ephemeral stream channels where much of the runoff infiltrates and becomes recharge. Without the concentrated runoff in the urban area, rainfall would be diffuse and would not be sufficient to percolate to the water table. As in high flows, the increase in low flows would have occurred after the 1970s.

Cattle grazing, and specifically overgrazing, in a watershed can increase high flows by decreasing landcover vegetation and compacting soils, which decreases the infiltration capacity of a soil and increases runoff. Overgrazing can decrease low flows in areas where there is naturally occurring recharge, because more water runs off and less water is available to percolate to the ground-water system and become recharge and eventually discharge. Cattle grazing can also result in a change in the types of vegetation, which may have different effects on runoff.

From 1880 to 1930 , there was likely some overgrazing and damage to vegetation and soils in the Upper San Pedro River Basin, and after 1930 there was no widespread damage because the cattle population slowly decreased to relatively low levels (Rodgers, 1965). During 1880 to 1900, there were about 15,000 to 35,000 cattle in the Upper San Pedro Basinmany more than the estimated carrying capacity of about 10,000 (the number of cattle that the land can sustain with no damage). During 1900 to 1930 , there were about 10,000 to 20,000 cattle - still more than the estimated carrying capacity. After 1930, the cattle population was at or below the carrying capacity, and it has decreased slowly as land use has changed from mostly ranching and agriculture to more urban and residential. In 1988, cattle were excluded from the SPRNCA.

The influence of cattle grazing on streamflow trends of the San Pedro River is difficult to determine because grazing may be one cause of the changes in vegetation that occurred during the 20th century. Results of this study indicate that changes in upland and riparian vegetation were a major factor in the decreasing trends in high flows and low flows. If cattle grazing was a major factor in the vegetation changes, then it was also a major indirect factor in the decreasing streamflow trends. This study did not evaluate the potential influence of cattle grazing on changes in vegetation; previous studies have suggested that there were three principal causes of vegetation changes - changes in climate, cattle grazing, and fire suppression (Hereford, 1993; Turner and others, 2003).

The overgrazing in the late 1800s and early 1900s could have caused an increase in high flows during that time by compacting soils, causing soil erosion, and damaging or removing vegetation. After the 1930s, when damage from grazing likely was minimal, soils and vegetation could have recovered slowly, which would have decreased high flows. The combination of the effects of overgrazing/recovery would result in a decreasing high-flow trend from before 1930 to after 1930. The same overgrazing/recovery could result in 
an increasing trend in low flows. It is impossible to separate the recovery process from overgrazing from the concurrent changes in vegetation, which could have been caused by changes in climate. This study can, therefore, only conclude that cattle grazing might have been a major indirect factor in the decreasing trends of high flows and low flows.

Numerous small runoff-detention structures were built on small tributaries throughout the watershed of the upper San Pedro River during the last 100 years (Hereford, 1993). These structures typically decrease high flows by capturing or slowing down runoff, and they increase low flows by increasing ground-water recharge and discharge. High-flow runoff (total flows and storm runoff) would be decreased immediately after construction and low flows would be increased months or years later.

Runoff-detention structures in the watershed probably were a factor in the decreasing trends in high flows; the degree of influence, however, is difficult to determine because accurate quantitative data on the number, size, location, and dates of construction are not available. The structures likely were not a major factor in the streamflow trends for two reasons. First, most of the structures likely were built in the first half of the 20th century and have been operating during most of the 20th century. This would result in a fairly constant effect of decreased high flows from the early 20th century until 2002 and no decreasing trend over time. The relative dates of construction are supported by some topographic maps and an assumed correlation between runoff-detention structures and cattle population. An evaluation of five 7.5-minute topographic maps published in the 1950s and revised in the 1980s showed that more than 90 percent of the runoff-detention structures shown on the maps were built before the 1950s. The number and dates of construction of runoff-detention structures likely have a moderate correlation with the cattle population in the watershed because many of the structures were built to create stock ponds for cattle (Hereford, 1993). Second, the structures should have had the same effect on all seasonal total flows, and trends in seasonal total flows were different (tables 18, 20, and 21).

Runoff-detention structures likely caused no trend or a minor increase in low flows. Increased recharge and eventually discharge is possible because water that originally flowed freely down a channel is impounded behind a structure where it could infiltrate and become recharge. An appreciable increasing trend in recharge and low flows is unlikely because (1) an evaluation of ten 7.5-minute topographic maps showed that many of the structures are on upland areas where there is minimal or no recharge potential, (2) Coes and Pool (2005) measured rapid infiltration rates of runoff in ephemeralstream channels of about 1 to $9 \mathrm{ft} / \mathrm{hr}$, so much of the runoff could infiltrate before being impounded by a runoff-detention structure, and (3) runoff-detention structures may have had a constant effect on streamflows for the entire 20th century, with no resulting trend in low flows.

\section{Summary and Conclusions}

This study was done to improve the understanding of trends in streamflow of the San Pedro River in southeastern Arizona. Annual streamflow of the river at Charleston, Arizona, has decreased by more than 50 percent during the 20th century. The San Pedro River is one of the few remaining free-flowing perennial streams in the arid Southwestern United States, and the riparian forest along the river supports several endangered species and is an important habitat for migratory birds. To make effective and informed decisions, resource managers and the public need to have a better understanding of the characteristics of the streamflow trends and the causes of the trends.

The first step in this study was to place the trends in streamflow of the San Pedro River in a regional perspective. Relations and trends in seasonal and annual precipitation and streamflow for surrounding areas $\left(7,000 \mathrm{mi}^{2}\right)$ were determined and compared to trends in the San Pedro River Basin (1,230 $\left.\mathrm{mi}^{2}\right)$. The second step was a detailed evaluation of trends in seasonal and annual precipitation and streamflow in the San Pedro River Basin. The third step evaluated trends in monthly streamflows of the San Pedro River and statistically distinguished between the effects of precipitation and the effects of factors other than precipitation. The last step incorporated results of all the analyses to evaluate the specific causes of streamflow trends.

Regional trends in seasonal and annual precipitation and streamflow were determined by analyzing precipitation data from 38 sites and streamflow data from 21 sites. The data were analyzed for 11 time periods starting every 5 years from 1930 to 1980 , and ending in 2002 (for example, 1930-2002, 1935-2002, and 1940-2002). No significant trends were found in 92 percent of the trend tests for precipitation, and no significant trends were found in 79 percent of the trend tests for streamflow. Most significant trends in spring, fall, and winter precipitation were for time periods that started during the mid-century drought in 1945-60. The time periods with significant trends in streamflow were not as clustered about the mid-century drought as were the precipitation trends. Significant streamflow trends generally started before 1955 .

For the trends in precipitation that were significant, 90 percent were positive and most of the significant negative trends were for summer precipitation. For the significant trends in streamflow, about half were positive and half were negative.

There are long-term temporal patterns or cycles in precipitation and streamflow in the study area. Winter and spring precipitation had much more pronounced cycles than summer or fall precipitation. Winter and spring precipitation was generally high in the 1930s, low in the 1950s and 1960s, high in the 1980s, and low in the late 1990s and early 2000s. Winter, spring, and fall streamflow in the northwest and northeast parts of the study area had similar long-term patterns as those seen in the precipitation data. In contrast to the obvious streamflow cycles in the northwest and northeast parts of the study area, streamflow in the San Pedro River mostly just decreased steadily. 
By most measures of precipitation and streamflow in the regional analysis, trends in the San Pedro River Basin are similar to trends in other basins in the southwest part of the study area and are generally not similar to trends in basins in the rest of the study area. The southwest part of the study area includes the San Pedro River Basin, the Whitewater Draw Basin to the east, and the Santa Cruz River Basin to the west. The only appreciable difference between the San Pedro Basin and other basins in the southwest part was in the degree of streamflow trends; trends in streamflow of the San Pedro River were more severe than trends in streamflow of Whitewater Draw and the Santa Cruz River, but all three streams still had similar seasonal patterns in trends.

There are several implications of the regional analysis:

- The southwest part of the study area is more vulnerable to changes in summer monsoon storms than the rest of study area, because more than half the annual precipitation and streamflow in the southwest part occurs in the summer.

- The southwest part of the study area appears to have more long-term problems with a decreasing surfacewater supply than the rest of the study area. Most significant trends in precipitation and streamflow in the southwest part were negative, and most significant trends in the rest of the study area were positive. The decreasing flow in the San Pedro River is well known, but the Santa Cruz River and Whitewater Draw also had significant decreasing trends in summer flows.

- There were more significant decreasing trends in streamflow than significant decreasing trends in precipitation in the southwest part of the study area. This indicates that some other factors besides precipitation may have influenced the streamflow trends.

To improve the understanding of trends in streamflow of the San Pedro River, a detailed evaluation was made of trends in precipitation, trends in streamflow, and trends in streamflow caused by factors other than precipitation. Trends from 1913 to 2002 were evaluated using precipitation data from Tombstone, Arizona, and streamflow data at Charleston, Arizona.

From 1913 to 2002, annual, winter, spring, and fall precipitation at Tombstone had no significant trends and summer precipitation had a significant decreasing trend. Changes in seasonal total flow and low flow for the San Pedro River were calculated from the predevelopment period (prior of 1940) to the 1990s. Annual total flow decreased from 57,700 to 22,000 acre-ft/yr, and summer total flow decreased from 31,400 to 6,300 acre-ft/yr. Annual low flow decreased from 7,900 to 4,300 acre-ft/yr, and summer low flow decreased from 900 to 300 acre-ft/yr.

The characteristics of trends in precipitation and streamflow during 1913 to 2002 were investigated by evaluating step trends over six time periods in the central tendency and variability of winter, summer, and fall values. Precipitation had mostly no trends in central tendency or variability. Streamflow, however, had both monotonic and step trends, and several notable differences in trends for the different seasons.
There was a step change in the central tendency of streamflows at about 1943; before 1943 all seasonal flows were high, and after 1943 all seasonal flows were generally low. The behavior of the seasonal flows after 1943 was different; summer flows decreased continuously, and fall and winter flows were mostly steady except for high values during 1977-89.

The interannual variability of seasonal streamflows also had patterns. The variability of winter streamflow had two distinct step changes; the variability was high during 1913-42, low during 1943-76, and high again during 1977-2002. Summer interannual variability decreased monotonically during the entire record. Fall interannual variability was generally similar for the entire record except for a high period during 1977-89.

Factors that caused the decreasing trends in streamflow of the San Pedro River at Charleston were investigated. Possible factors were fluctuations in precipitation and air temperature, changes in watershed characteristics, human activities, or changes in seasonal distribution of bank storage. This study statistically removed or accounted for the variation in streamflow caused by fluctuations in precipitation. Thus, the remaining variation or trend in streamflow was caused by factors other than precipitation.

Partitioning of the variation in streamflow and testing to determine trends in the partitioned variation was done using two methods: (1) regression analysis between precipitation and streamflow using all years in the record and evaluation of time trends in regression residuals, and (2) development of regression equations between precipitation and streamflow for three time periods (early, middle, and late parts of the record) and testing to determine if the three regression equations are significantly different. Method 1 is an evaluation of monotonic changes for the entire record, and method 2 is an evaluation of step changes over three time periods in the record. The methods were applied to monthly values of total flow (average flow) and storm runoff (maximum daily mean flow) for 1913-2002, and to monthly values of low flow (3-day low flow) for 1931-2002.

Statistical tests provide strong evidence that factors other than precipitation caused a decrease in streamflow of the San Pedro River. Factors other than precipitation caused significant decreasing trends in streamflows for late spring through early winter, and did not cause significant trends for late winter through early spring. Total flows had significant trends in June through December, low flows had significant trends in May through December, and storm runoff had significant trends in July through September. The effects of factors other than precipitation were only tested for July through October for storm runoff.

The specific factor or factors (besides precipitation) that caused the decreasing streamflow of the San Pedro River is difficult to determine because of interaction among the different factors and because historical data on the possible factors is more qualitative than quantitative. Possible changes in watershed characteristics that may have influenced streamflow trends are changes in riparian vegetation, changes in upland vegetation, and changes in stream-channel morphology. Possible human activities that may have 
influenced streamflow trends are ground-water pumping, construction of runoff-detention structures, urbanization, and cattle ranching (grazing).

Changes in upland and riparian vegetation likely were major factors in the decreasing trends in total streamflows and low flows. Total flows and low flows in summer and fall were significantly affected by factors other than precipitation, but late winter flows were not significantly affected. The significant effects coincide with high rates of transpiration from vegetation in the summer, and the nonsignificant effects coincide with low rates of transpiration in the late winter. Another piece of evidence that implicates vegetation as a cause is that the upland and riparian vegetation of the San Pedro River Basin changed during the 20th century. The relative proportions of different species changed in upland vegetation (woody plants increased and grasses decreased), and the areal extent and density of riparian vegetation increased substantially.

Ground-water pumping in the United States and Mexico had a mixed influence on streamflow trends at Charleston; the degree of influence depends on the location of pumping wells and the amount of pumping. Statistical analyses indicate that seasonal pumping from wells near the river for irrigation in the spring and summer was a major factor in the decrease in low flows and that year-round pumping from wells in the regional aquifer away from the river was not a major factor in the decrease in low flows. If regional pumping had caused a trend, the pumping should have affected low flows for all months of the year, but factors other than precipitation did not cause significant trends in low flows for January, February, March, and May. Most of the local pumping near the river was during the spring and summer, and this seasonal pumping probably caused some decreases in summer low flows. These conclusions are for trends from 1913 to 2002, and regional U.S. and Mexico pumping could affect streamflow at Charleston in the future, because regional ground-water pumping often has a delayed effect on streamflows.

Other factors (besides precipitation, vegetation, and seasonal ground-water pumping near the river) had varying degrees of influence on the streamflow trends of the San Pedro River. Changes in stream-channel morphology, runoffdetention structures, and cattle grazing likely were factors in the decreasing trends in total flows. Some physical processes and historical data support the factors as a cause of decreasing total flows, but statistical tests in this study indicated each factor was not a major influence. Although not major factors in themselves, their cumulative effect could have been major. Change in bank storage over time likely was another factor in some of the decreasing tends in seasonal low flows. The large decreasing trends in total flows during the summer would have decreased bank storage over time and decreased the subsequent release of bank storage during the fall and early winter. This decreased bank storage likely had an effect on the decreasing trends in fall and early winter low flows.

\section{References Cited}

Alley, W.M., 1988, Using exogenous variables in testing for monotonic trends in hydrologic time series: Water Resources Research, v. 24, no. 11, p. 1955-1961.

Alley, W.M., Reilly, T.E., and Franke, O.L., 1999, Sustainability of ground-water resources: U.S. Geological Survey Circular 1186, 79 p.

Arizona Department of Water Resources, 2005, Upper San Pedro Basin Active Management Area Review Report: Phoenix, Arizona Department of Water Resources, 219 p.

City of Sierra Vista, 2005, City of Sierra Vista, accessed May 17, 2005, at http://www.ci.sierra-vista.az.us/ Community\%Profile/facts.htm

Cleveland, W.S., 1979, Robust locally weighted regression and smoothing scatterplots: Journal American Statistical Association, v. 74, p. 829-836.

Coes, A.L., and Pool, D.R., 2005, Ephemeral-stream channel and basin-floor infiltration and recharge in the Sierra Vista subwatershed of the Upper San Pedro Basin, Southeastern Arizona: U.S. Geological Survey Open-File Report 2005-1023, 63 p.

Consultores en Agua Subterranea S.A. para Mexicana de Cananea, S.A. de C.V., 2000, Actualización del estudio geohidrológico de las cuencas del Río San Pedro y norte del Río Sonora en Cananea: Sonora, Mexico, 136 p.

Corell, S.W., Corkhill, Frank, Lovvik, D., and Putnam, F., 1996, A groundwater flow model of the Sierra Vista Subwatershed of the upper San Pedro Basin, southeastern Arizona: Phoenix, Arizona Department of Water Resources Modeling Report No. 10, 107 p.

De Aguinaga, José Guillermo Ruiz Esparza, 2002, Modelación geohidrológica del acuifero del Río San Pedro: Hermosillo, Sonora, México, Universidad de Sonora, División de Ciencias Exactas y Naturales, tesis professional, 75 p.

Draper, N.R., and Smith, H., 1981, Applied regression analysis (2d ed): New York, John Wiley and Sons, Inc., 709 p.

Freethey, G.W., 1982, Hydrologic analysis of the upper San Pedro Basin from the Mexico-United States International Boundary to Fairbank, Arizona: U.S. Geological Survey Open-File Report 82-752, 60 p.

GeoSystems Analysis, 2004, Storm water recharge feasibility analysis: Tucson, Arizona, GeoSystems Analysis SP-0011, $30 \mathrm{p}$. 
Goode, T.C., and Maddock, Thomas, III, 2000, Simulations of groundwater conditions in the upper San Pedro Basin for the evaluation of alternative futures: Tucson, University of Arizona, Department of Hydrology and Water Resources report No. 00-030, $113 \mathrm{p}$.

Helsel, D.R., and Hirsch, R.M., 1992, Statistical methods in water resources: New York, Elesevier Science Publishing Company, Inc., 522 p.

Hereford, Richard, 1993, Entrenchment and widening of the upper San Pedro River, Arizona: Geological Society of America Special Paper 282, 46 p.

Hereford, Richard, Webb, R.H., and Graham, S., 2002, Precipitation history of the Colorado Plateau region, 1900-2000: U.S. Geological Survey Fact Sheet 119-02, 9 p.

Hurd, B., Leary, N., Jones, R., and Smith, J., 1999, Relative regional vulnerability of water resources to climate change: Journal of the American Water Resources Association, v. 35 , no. 6 , p. 1399-1409.

Insightful, 2001, S-Plus 6 for windows guide to statistics, v. 1: Seattle, Washington, Insightful Corporation, $730 \mathrm{p}$.

Kepner, W.G., and Edmonds, C.M., 2002, Remote sensing and geographic information systems for decision analysis in public resource administration-A case study of 25 years of landscape change in a southwestern watershed: U.S. Environmental Protection Agency report EPA/600/R-02/039, 23 p.

Lacey, J.R., Ogden, P.R., and Foster, K.E., 1975, Southern Arizona riparian habitat-Spatial distribution and analysis: Tucson, University of Arizona Office of Arid Lands Bulletin 8, $148 \mathrm{p}$.

Lins, H.F., and Slack, J.R., 1999, Streamflow trends in the United States: Geophysical Research Letters, v. 26, no. 2, p. 227-230.

McCabe, J.G., and Dettinger, M.D., 1999, Decadal variations in the strength of ENSO teleconnections with precipitation in the western United States: International Journal of Climatology, v. 19, p. 1399-1410.

Ott, R.L., 1993, An introduction to statistical methods and data analysis (4th ed): Belmont, California, Wadsworth Publishing Company, $1051 \mathrm{p}$.

Pool, D.R., and Coes, A.L., 1999, Hydrogeologic investigations of the Sierra Vista subwatershed of the Upper San Pedro Basin, Cochise County, southeast Arizona: U.S. Geological Survey Water-Resources Investigations Report 99-4197, 41 p.

Rodgers, W.M., 1965, Historical land occupance [sic] of the upper San Pedro River valley since 1870: Tucson, University of Arizona, unpublished master's thesis, $167 \mathrm{p}$.
Rojo, H.A., Bredehoft, John, Lacwell, Ronald, Price, Jeff, Stromberg, Julie, and Thomas, G.A., 1999, Sustaining and enhancing riparian migratory bird habitat on the upper San Pedro River: Final draft from the San Pedro expert study team prepared for the Secretariat of the Commission for Environmental Cooperation, March 1999, 123 p.

Scott, R.L., Shuttleworth, W.J., Goodrich, D.C., and Maddock, Thomas, III, 2000, The water use of two dominant vegetation communities in a semiarid riparian ecosystem: Journal of Agriculture and Forest Meteorology, v. 105, nos. 1-3, p. 241-256.

Sharma, Vandana, MacNish, R.D., and Maddock, Thomas, III, 1997, Analysis of hydrologic data collected by the U.S. Bureau of Land Management 1987-1995 and recommendations for future monitoring programs: Tucson, University of Arizona, Arizona Research Laboratory for Riparian Studies, Department of Hydrology and Water Resources, HWR No. 97-060, 61 p.

Sokal, R.R., and Rohlf, F.J., 1995, Biometry (3d ed): New York, W.H. Freeman and Company, 887 p.

Southwest Ground-Water Consultants, 2004, Water supply potential—Phelps Dodge Copper Queen Mine: Phoenix, Arizona, Southwest Ground-Water Consultants, Inc., 24 p.

Stromberg, Julie, 1998, Dynamics of Fremont cottonwood (Populus fremontii) and saltcedar (Tamarix chinensis) populations along the San Pedro River, Arizona: Journal of Arid Environments, v. 40, p. 133-155.

Tabachnick, B.G., and Fidell, L.S., 2001, Using multivariate statistics (4th ed): Needham Heights, Massachusetts, Allyn and Bacon, $966 \mathrm{p}$.

Turner, R.M., Webb, R.H., Bowers, J.E., and Hastings, J.R., 2003, The changing mile revisited: Tucson, University of Arizona Press, 334 p.

Upper San Pedro Partnership, 2002, Upper San Pedro Conservation Plan 2002 Progress Report: accessed May 17, 2005, at http//www.usppartnership.com/ documents/2002ConservPlan.pdf

Vionnet, L.B., and Maddock, Thomas, III, 1992, Modeling of ground-water flow and surface/groundwater interaction for the San Pedro River Basin, part 1, Mexican border to Fairbank, Arizona: Tucson, University of Arizona, Department of Hydrology and Water Resources report 92-010, $202 \mathrm{p}$.

Webb, R.H., McCabe, G.J., Hereford, Richard, and Wilkowske, C., 2004, Climatic fluctuations, drought, and flow in the Colorado River Basin: U.S. Geological Survey Fact Sheet 2004-3062, 4 p. 
Appendices 1-2 


\section{Appendix 1}

\section{Evaluation of Effects of Different Streamflow- Gaging Station Locations on Trend Analysis}

The gaging station San Pedro River at Charleston, Arizona (09471000), was moved several times during the record from 1913 to 2002. There were three general locations that were appreciably different. The first location was near Fairbank, Arizona, from September 12, 1912, to September 30, 1926. During that time the station was moved once about 1,000 ft, but there were no tributaries between the two locations, so the streamflow record can be considered equivalent from 1912 to 1926 . The Fairbank site was about $7 \mathrm{mi}$. downstream from the current site, and the drainage area of the Fairbank site was about 1,300 mi2. The station was at its second location from May 1928 to November 30, 1942. That station was about $1.7 \mathrm{mi}$. downstream from the current site and the drainage area was about 1,250 $\mathrm{mi} 2$. The station has been at its current location since December 1, 1942, and its drainage area is $1,234 \mathrm{mi} 2$.

The effects of the different station locations on the trend analyses of streamflow performed in this study could not be directly determined. Three analyses were made, however, to indirectly evaluate the effects of the different locations. First, the graphs of precipitation-adjusted streamflow versus time were visually inspected to determine if there were any obvious breaks or jumps in the data after a station move. Such a break or jump might indicate an important difference in the effects of factors other than precipitation that was caused by the move. The second more rigorous analysis was to perform the same trend analysis of streamflow and adjusted streamflow for only the period of record where the station was at one location-from 1943 to 2002. Values of monthly total flow (average flow), monthly low flow (3-day low flow), and storm runoff (maximum daily mean flow for each month) were analyzed. The third analysis was to adjust the flows from the earlier records according to the drainagearea ratio of the station sites, and then perform the same trend analysis of streamflow and adjusted streamflow. From 1913 to 1926 , the drainage-area ratio was 0.947 , and from 1928 to 1942 , the ratio was 0.987 . Thus, flows in the early record are adjusted downward to make them more equivalent to the flows from the current station location. Monthly total flow and maximum daily storm runoff were analyzed. Low flows were not analyzed using station-adjusted flows; low flows should have little correlation to size of drainage area because most low flow is ground-water discharge.

Visual inspection of the plots of adjusted streamflow versus time show no apparent breaks or jumps in the plots at the time of station moves-1926 and 1943 (figs. 13-15). Results of the trend analysis of streamflow data using the record from the current station location from 1943 to 2002 (tables 1A-1F) are similar to the results of the analysis of data for the entire record from 1913 to 2002 (tables 14-20). There were differences in the magnitude of trends (p-values) and a couple monthly-flow trends changed from significant to nonsignificant, but the overall conclusions about seasonal trends did not change. Results of the analysis of streamflows adjusted for station location (tables $1 \mathrm{G}-1 \mathrm{~J}$ ) were very similar to results of the analysis of the flows not adjusted for location (tables 14-20). Trends in monthly total flows for FebruaryDecember were the same, and January total flow changed from nearly significant to not significant. Trends in storm runoff were the same. 
Table 1A. Results of LOWESS regression analyses between precipitation at Tombstone, Arizona, and monthly total streamflow for the San Pedro River at Charleston, Arizona, and between precipitation at Tombstone and time, 1943-2002

$\left[R^{2}\right.$, coefficient of multiple determination]

LOWESS regression models ${ }^{2}$

\begin{tabular}{|c|c|c|c|c|c|c|c|c|}
\hline & & & & & & & & \\
\hline & & & & & Respo & iable & & \\
\hline & & Explanatory variables & & $\begin{array}{l}\text { Total streamflow } \\
\text { bic feet per seco }\end{array}$ & & & $\begin{array}{c}\text { Time } \\
\text { (years) }\end{array}$ & \\
\hline Month & $\begin{array}{c}\text { years } \\
\text { analyzed' }\end{array}$ & $\begin{array}{l}\text { Monthly precipitation } \\
\text { (inches) }\end{array}$ & $R^{2}$ & $\begin{array}{l}\text { Standard error } \\
\text { (log units) }\end{array}$ & Span $^{3}$ & $R^{2}$ & $\begin{array}{c}\text { Standard error } \\
\text { (years) }\end{array}$ & Span $^{3}$ \\
\hline January & 48 & Nov., Dec., and Jan. & 0.82 & 0.283 & 0.50 & 0.47 & 15.49 & 0.90 \\
\hline February & 48 & Dec, Jan., and Feb. & .74 & .209 & .75 & .66 & 17.88 & .50 \\
\hline March & 51 & Jan., Feb., and Mar. & .87 & .174 & .50 & .60 & 16.76 & .60 \\
\hline April & 51 & Jan., Feb., and Mar. & .67 & .136 & .60 & .60 & 16.76 & .60 \\
\hline May & 51 & Jan., Feb., and Mar. & .63 & .191 & .50 & .60 & 16.76 & .60 \\
\hline June & 50 & Dec., Mar., and June & .78 & .303 & .50 & .42 & 19.58 & .60 \\
\hline July & 54 & May, June, and July & .74 & .440 & .60 & .42 & 18.45 & .60 \\
\hline August & 53 & June, July, and Aug. & .68 & .370 & .75 & .56 & 16.38 & .60 \\
\hline September & 54 & May, Aug., and Sept. & .70 & .372 & .75 & .49 & 18.16 & .60 \\
\hline October & 55 & May, Sept., and Oct. & .89 & .290 & .60 & .61 & 18.44 & .50 \\
\hline November & 54 & June, Oct., and Nov. & .84 & .162 & .50 & .58 & 17.48 & .50 \\
\hline December & 53 & Oct., Nov., and Dec. & .80 & .296 & .50 & .53 & 19.72 & .50 \\
\hline
\end{tabular}

${ }^{1}$ Time period for analysis was 1943-2002.

${ }^{2}$ LOWESS regression models:

Response variable, total streamflow: $\log Q_{\mathrm{n}}=\log P_{1}+\log P_{2}+\log P_{\mathrm{n}}$ where $Q_{\mathrm{n}}$ is average streamflow for month $\mathrm{n}$, in cubic feet per second, and $P_{\mathrm{n}}$ is precipitation for month $\mathrm{n}$, in inches.

Response variable, time: $T_{\mathrm{n}}=\log P_{1}+\log P_{2}+\log P_{\mathrm{n}}$ where $T_{\mathrm{n}}$ is time for month $\mathrm{n}$, in years, and $P_{n}$ is precipitation for month $\mathrm{n}$, in inches.

${ }^{3}$ Span is a parameter that controls the window width and smoothness of the fitted LOWESS model. As the span is increased, the window width is increased and more points influence the magnitude of the fitted values. Thus, a larger span will have a smoother fitted model than a smaller span. 
Table 1B. Results of LOWESS regression analyses between precipitation at Tombstone, Arizona, and monthly low flow for the San Pedro River at Charleston, Arizona, and between precipitation at Tombstone and time, 1943-2002

$\left[R^{2}\right.$, coefficient of multiple determination]

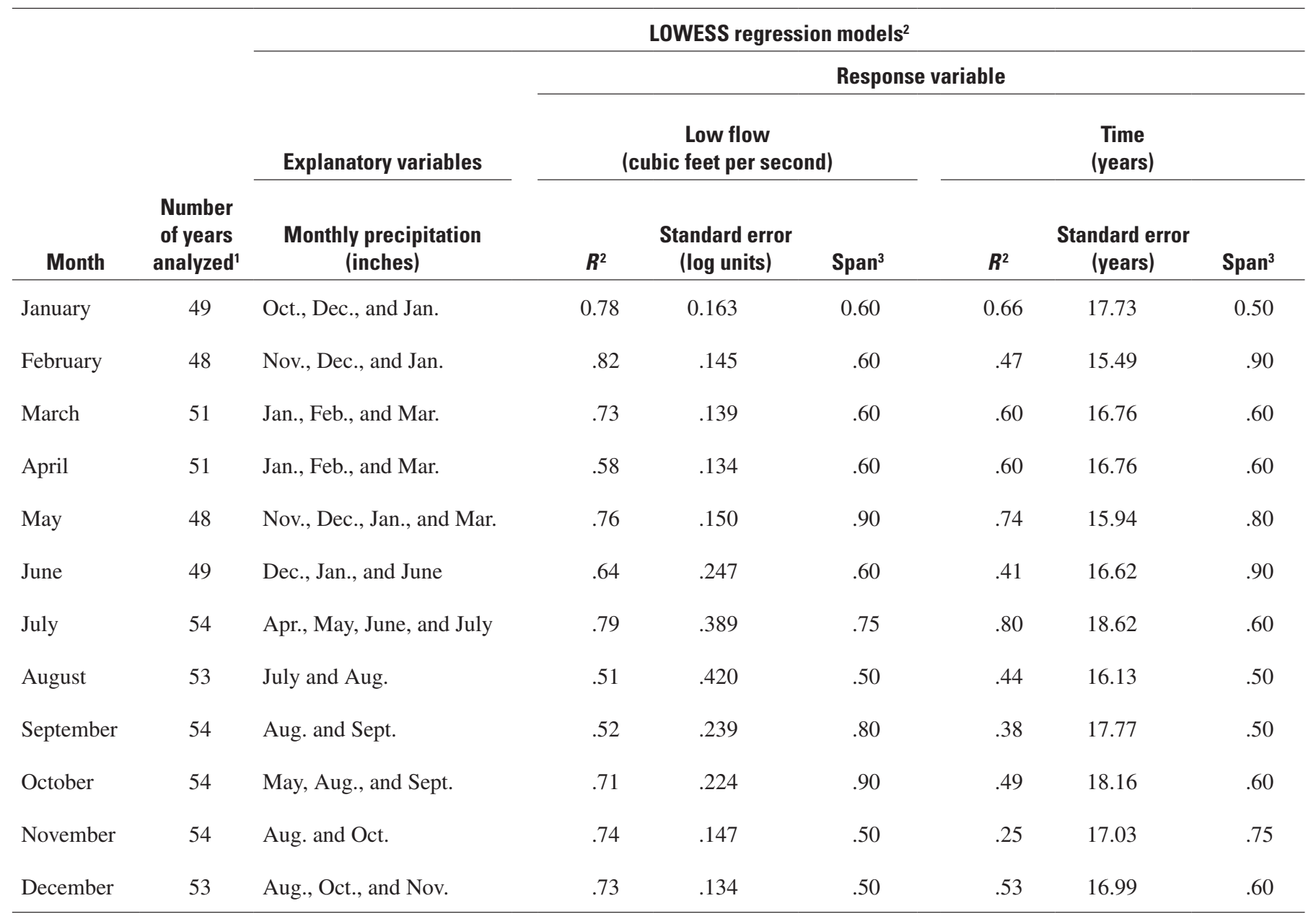

${ }^{1}$ Time period for analysis was 1943-2002.

${ }^{2}$ LOWESS regression models:

Response variable, low flow: $\log Q_{\mathrm{n}}=\log P_{1}+\log P_{2}+\log P_{\mathrm{n}}$ where $Q_{\mathrm{n}}$ is 3-day low flow for month n, in cubic feet per second, and $P_{\mathrm{n}}$ is precipitation for month $\mathrm{n}$, in inches

Response variable, time: $T_{\mathrm{n}}=\log P_{1}+\log P_{2}+\log P_{\mathrm{n}}$ where $T_{\mathrm{n}}$ is time for month $\mathrm{n}$, in years, and $P_{\mathrm{n}}$ is precipitation for month n, in inches.

${ }^{3}$ Span is a parameter that controls the window width and smoothness of the fitted LOWESS model. As the span is increased, the window width is increased and more points influence the magnitude of the fitted values. Thus, a larger span will have a smoother fitted model than a smaller span. 
Table 1C. Results of LOWESS regression analyses between precipitation at Tombstone, Arizona, and maximum daily storm runoff for the San Pedro River at Charleston, Arizona, and between precipitation at Tombstone and time, 1943-2002, for selected months

$\left[R^{2}\right.$, coefficient of multiple determination $]$

LOWESS regression models ${ }^{2}$

\begin{tabular}{|c|c|c|c|c|c|c|c|c|}
\hline \multirow[b]{3}{*}{ Month } & \multirow[b]{3}{*}{$\begin{array}{c}\text { Number of } \\
\text { years } \\
\text { analyzed }\end{array}$} & \multirow[b]{2}{*}{ Explanatory variables } & \multicolumn{6}{|c|}{ Response variable } \\
\hline & & & \multicolumn{3}{|c|}{$\begin{array}{l}\text { Maximum daily storm runoff } \\
\text { (cubic feet per second) }\end{array}$} & \multicolumn{3}{|c|}{$\begin{array}{c}\text { Time } \\
\text { (years) }\end{array}$} \\
\hline & & $\begin{array}{l}\text { Monthly precipitation } \\
\text { (inches) }\end{array}$ & $R^{2}$ & $\begin{array}{l}\text { Standard error } \\
\text { (log units) }\end{array}$ & Span $^{3}$ & $R^{2}$ & $\begin{array}{l}\text { Standard error } \\
\text { (years) }\end{array}$ & $\operatorname{Span}^{3}$ \\
\hline June & 20 & $\mathrm{p}_{0}$ and $\mathrm{p}_{1-10}$ & 0.54 & 0.689 & 0.60 & 0.51 & 15.98 & 0.90 \\
\hline July & 54 & $\mathrm{p}_{0}, \mathrm{p}_{1-10}$, and $\mathrm{p}_{11-30}$ & .67 & .471 & 60 & .45 & 16.26 & .80 \\
\hline August & 55 & $\mathrm{p}_{0}$ and $\mathrm{p}_{1-30}$ & .32 & .470 & .75 & $\left({ }^{4}\right)$ & $\left({ }^{4}\right)$ & $\left({ }^{4}\right)$ \\
\hline September & 49 & $\mathrm{p}_{0}, \mathrm{p}_{1-10}$, and $\mathrm{p}_{11-30}$ & .63 & .621 & .60 & .49 & 16.16 & .80 \\
\hline October & 23 & $\mathrm{p}_{0}$ and $\mathrm{p}_{1-30}$ & .85 & .442 & .80 & .47 & 16.26 & .90 \\
\hline
\end{tabular}

${ }^{1}$ Time period for analysis was 1943-2002.

${ }^{2}$ LOWESS regression models:

Response variable, maximum daily storm runoff: $\log Q_{\mathrm{n}}=\log P_{1}+\log P_{2}+\log P_{\mathrm{m}}$, where $Q$ is maximum daily mean flow for month n, in cubic feet per second, and $\mathrm{P}_{\mathrm{m}}$ is precipitation for indicated days previous to day of runoff $\left(\mathrm{p}_{0}\right.$ is precipitation for day of runoff, $\mathrm{p}_{1-10}$ is cumulative precipitation for days 1 through 10 prior to runoff), in inches

Response variable, time: $T_{\mathrm{n}}=\log P_{1}+\log P_{2}+\log P_{\mathrm{m}}$, where $T$ is time for month $\mathrm{n}$, in years, and $P_{\mathrm{m}}$ is precipitation for indicated days previous to day of runoff, in inches.

${ }^{3}$ Span is a parameter that controls the window width and smoothness of the fitted LOWESS model. As the span is increased, the window width is increased and more points influence the magnitude of the fitted values. Thus, a larger span will have a smoother fitted model than a smaller span.

${ }^{4}$ LOWESS regression analysis between precipitation and time was not done because the LOWESS equation between precipitation and maximum runoff was not sufficiently accurate $\left(R^{2}<0.50\right)$. 
Table 1D. Trends in monthly total streamflow and monthly total streamflow adjusted for variation in precipitation, San Pedro River at Charleston, Arizona, 1943-2002

$[<$, less than; $>$, greater than $]$

\begin{tabular}{|c|c|c|c|c|c|c|c|}
\hline \multirow[b]{3}{*}{ Month } & \multicolumn{7}{|c|}{ Total streamflow (1943-2002) ${ }^{1}$} \\
\hline & \multirow{2}{*}{$\begin{array}{c}\text { Number of } \\
\text { years analyzed }\end{array}$} & \multicolumn{2}{|c|}{ Streamflow and time } & \multicolumn{2}{|c|}{$\begin{array}{c}\text { Adjusted streamflow } \\
\text { and time }\end{array}$} & \multicolumn{2}{|c|}{$\begin{array}{l}\text { Adjusted streamflow } \\
\text { and adjusted time }\end{array}$} \\
\hline & & Slope ${ }^{4}$ & p-value & Slope $^{4}$ & p-value & Slope ${ }^{4}$ & p-value \\
\hline February & 48 & $\mathrm{p}$ & .729 & $\mathrm{n}$ & .351 & $\mathrm{n}$ & .259 \\
\hline March & 51 & $\mathrm{p}$ & .852 & $\mathrm{p}$ & .987 & $\mathrm{p}$ & .909 \\
\hline April & 51 & $\mathrm{p}$ & .673 & $\mathrm{n}$ & .455 & $\mathrm{n}$ & .626 \\
\hline July & 54 & $\mathrm{n}$ & $<.001$ & $\mathrm{n}$ & .005 & $\mathrm{n}$ & $<.001$ \\
\hline August & 53 & $\mathrm{n}$ & .003 & $\mathrm{n}$ & .031 & $\mathrm{n}$ & .005 \\
\hline September & 54 & $\mathrm{n}$ & .202 & $\mathrm{n}$ & .011 & $\mathrm{n}$ & $<.001$ \\
\hline October & 55 & $\mathrm{n}$ & .147 & $\mathrm{n}$ & .117 & $\mathrm{n}$ & .212 \\
\hline November & 54 & $\mathrm{n}$ & .031 & $\mathrm{n}$ & .066 & $\mathrm{n}$ & .017 \\
\hline December & 53 & $\mathrm{n}$ & .145 & $\mathrm{n}$ & .003 & $\mathrm{n}$ & $<.001$ \\
\hline
\end{tabular}

${ }^{1}$ Average streamflow.

${ }^{2}$ Variation in streamflow that was caused by variation in precipitation was removed by LOWESS regression analysis.

${ }^{3}$ Variations in streamflow and time that were caused by variation in precipitation were removed by LOWESS regression analysis.

${ }^{4}$ Slope of trend: $\mathrm{n}$ is negative and $\mathrm{p}$ is positive.

\begin{tabular}{|c|l|l|}
\cline { 3 - 3 } \multicolumn{2}{c|}{} & $p$-value \\
\hline$n$ or $p$ & no significant trend & $>0.10$ \\
\hline$n$ & nearly significant negative trend & $0.05-0.10$ \\
\hline$n$ & significant negative trend & $<0.05$ \\
\hline
\end{tabular}


Table 1E. Trends in monthly low flow and monthly low flow adjusted for variation in precipitation, San Pedro River at Charleston, Arizona, 1943-2002

$[<$, less than; $>$, greater than]

\begin{tabular}{|c|c|c|c|c|c|c|c|}
\hline \multirow[b]{4}{*}{ Month } & \multicolumn{7}{|c|}{ Low flow (1943-2002) ${ }^{1}$} \\
\hline & \multirow{3}{*}{$\begin{array}{c}\text { Number of } \\
\text { years analyzed }\end{array}$} & \multicolumn{6}{|c|}{ Kendall tau trend test } \\
\hline & & \multicolumn{2}{|c|}{ Flow and time } & \multicolumn{2}{|c|}{ Adjusted flow and time ${ }^{2}$} & \multicolumn{2}{|c|}{ Adjusted flow and adjusted time } \\
\hline & & Slope $^{4}$ & p-value & Slope ${ }^{4}$ & p-value & Slope ${ }^{4}$ & p-value \\
\hline January & 49 & $\mathrm{n}$ & .208 & $\mathrm{n}$ & 0.211 & 0.0 & 1.000 \\
\hline February & 48 & $\mathrm{n}$ & .709 & $\mathrm{p}$ & .810 & $\mathrm{n}$ & 0.576 \\
\hline March & 51 & $\mathrm{p}$ & .757 & $\mathrm{p}$ & .721 & $\mathrm{p}$ & 0.330 \\
\hline April & 51 & $\mathrm{n}$ & .354 & $\mathrm{n}$ & .047 & $\mathrm{n}$ & 0.015 \\
\hline May & 48 & $\mathrm{n}$ & .002 & $\mathrm{n}$ & .282 & $\mathrm{n}$ & 0.143 \\
\hline June & 49 & $\mathrm{n}$ & $<.001$ & $\mathrm{n}$ & .017 & $\mathrm{n}$ & 0.010 \\
\hline July & 54 & $\mathrm{n}$ & .001 & $\mathrm{n}$ & .026 & $\mathrm{n}$ & 0.016 \\
\hline August & 53 & $\mathrm{n}$ & $<.001$ & $\mathrm{n}$ & .014 & $\mathrm{n}$ & $<0.001$ \\
\hline September & 54 & $\mathrm{n}$ & .042 & $\mathrm{n}$ & $<.001$ & $\mathrm{n}$ & 0.001 \\
\hline October & 54 & $\mathrm{n}$ & .055 & $\mathrm{n}$ & .006 & $\mathrm{n}$ & 0.001 \\
\hline November & 54 & $\mathrm{n}$ & .063 & $\mathrm{n}$ & .002 & $\mathrm{n}$ & 0.001 \\
\hline December & 53 & $\mathrm{n}$ & .036 & $\mathrm{n}$ & .041 & $\mathrm{n}$ & $<0.001$ \\
\hline
\end{tabular}

${ }^{1}$ Three-day low flow.

${ }^{2}$ Variation in flow that was caused by variation in precipitation was removed by LOWESS regression analysis.

${ }^{3}$ Variations in flow and time that were caused by variation in precipitation were removed by LOWESS regression analysis.

${ }^{4}$ Slope of trend: $\mathrm{n}$ is negative and $\mathrm{p}$ is positive.

\begin{tabular}{|c|l|l|}
\cline { 3 - 3 } \multicolumn{2}{l|}{} & $\mathrm{p}$-value \\
\hline $\mathrm{n}$ or $\mathrm{p}$ & no significant trend & $>0.10$ \\
\hline $\mathrm{n}$ & nearly significant negative trend & $0.05-0.10$ \\
\hline $\mathrm{n}$ & significant negative trend & $<0.05$ \\
\hline
\end{tabular}


Table 1F. Trends in maximum daily storm runoff and maximum daily storm runoff adjusted for variation in precipitation, by month, San Pedro River at Charleston, Arizona, 1943-2002

$[<$, less than; $>$, greater than $]$

\section{Storm runoff (1943-2002)}

Kendall tau trend test

\begin{tabular}{|c|c|c|c|c|c|c|c|}
\hline \multirow[b]{2}{*}{ Month } & \multirow{2}{*}{$\begin{array}{c}\text { Number of } \\
\text { years analyzed }\end{array}$} & \multicolumn{2}{|c|}{ Runoff and time } & \multicolumn{2}{|c|}{ Adjusted runoff and time ${ }^{2}$} & \multicolumn{2}{|c|}{$\begin{array}{l}\text { Adjusted runoff and } \\
\text { adjusted time }{ }^{3}\end{array}$} \\
\hline & & Slope $^{4}$ & p-value & Slope $^{4}$ & p-value & Slope $^{4}$ & p-value \\
\hline January & 11 & $\mathrm{p}$ & 0.640 & $\left({ }^{6}\right)$ & $\left({ }^{6}\right)$ & $\left({ }^{6}\right)$ & $\left({ }^{6}\right)$ \\
\hline February & 9 & $\left({ }^{5}\right)$ & $\left({ }^{5}\right)$ & $\left({ }^{5}\right)$ & $\left({ }^{5}\right)$ & $\left({ }^{5}\right)$ & $\left({ }^{5}\right)$ \\
\hline March & 9 & $\left({ }^{5}\right)$ & $\left({ }^{5}\right)$ & $\left({ }^{5}\right)$ & $\left({ }^{5}\right)$ & $\left({ }^{5}\right)$ & $\left({ }^{5}\right)$ \\
\hline April & 6 & $\left({ }^{5}\right)$ & $\left({ }^{5}\right)$ & $\left({ }^{5}\right)$ & $\left({ }^{5}\right)$ & $\left({ }^{5}\right)$ & $\left({ }^{5}\right)$ \\
\hline May & 3 & $\left({ }^{5}\right)$ & $\left({ }^{5}\right)$ & $\left({ }^{5}\right)$ & $\left({ }^{5}\right)$ & $\left({ }^{5}\right)$ & $\left({ }^{5}\right)$ \\
\hline June & 20 & $\mathrm{n}$ & .256 & $\mathrm{n}$ & .770 & $\mathrm{n}$ & .183 \\
\hline July & 54 & $\mathrm{n}$ & $<.001$ & $\mathrm{n}$ & .001 & $\mathrm{n}$ & $<.001$ \\
\hline August & 55 & $\mathrm{n}$ & .008 & $\left({ }^{7}\right)$ & $\left({ }^{7}\right)$ & $\left({ }^{7}\right)$ & $\left({ }^{7}\right)$ \\
\hline September & 49 & $\mathrm{n}$ & .305 & $\mathrm{n}$ & .103 & $\mathrm{n}$ & .013 \\
\hline October & 23 & $\mathrm{p}$ & .161 & $\mathrm{p}$ & .833 & $\mathrm{p}$ & .751 \\
\hline November & 10 & $\mathrm{n}$ & .858 & $\left({ }^{6}\right)$ & $\left({ }^{6}\right)$ & $\left({ }^{6}\right)$ & $\left({ }^{6}\right)$ \\
\hline December & 12 & $\mathrm{p}$ & .193 & $\left({ }^{6}\right)$ & $\left({ }^{6}\right)$ & $\left({ }^{6}\right)$ & $\left({ }^{6}\right)$ \\
\hline
\end{tabular}

${ }^{1}$ Maximum daily mean streamflow for month.

${ }^{2}$ Variation in runoff that was caused by variation in precipitation was removed by LOWESS regression analysis.

${ }^{3}$ Variations in runoff and time that were caused by variation in precipitation were removed by LOWESS regression analysis.

${ }^{4}$ Slope of trend: $\mathrm{n}$ is negative and $\mathrm{p}$ is positive.

${ }^{5}$ Sufficient data were not available to perform trend analysis.

${ }^{6}$ Sufficient data were not available to perform LOWESS regression analysis and to create adjusted values of runoff and time.

${ }^{7}$ LOWESS regression equations for June and August runoff were not accurate enough to use for adjusted values of runoff and time.

\begin{tabular}{|c|l|l|}
\cline { 3 - 3 } \multicolumn{2}{c|}{} & p-value \\
\hline$n$ or $p$ & no significant trend & $>0.10$ \\
\hline$n$ & significant negative trend & $<0.05$ \\
\hline
\end{tabular}


Table 1G. Results of LOWESS regression analyses between precipitation at Tombstone, Arizona, and station-adjusted monthly total streamflow for the San Pedro River at Charleston, Arizona, and between precipitation at Tombstone and time, 1913-2002

$\left[R^{2}\right.$, coefficient of multiple determination]

\begin{tabular}{|c|c|c|c|c|c|c|c|c|}
\hline \multirow[b]{4}{*}{ Month } & \multirow{4}{*}{$\begin{array}{l}\text { Number of } \\
\text { years } \\
\text { analyzed }\end{array}$} & \multicolumn{7}{|c|}{ LOWESS regression models ${ }^{2}$} \\
\hline & & \multirow[b]{2}{*}{ Explanatory variables } & & \multicolumn{5}{|c|}{ Response variable } \\
\hline & & & \multicolumn{3}{|c|}{$\begin{array}{l}\text { Station-adjusted total streamflow }{ }^{3} \\
\text { (cubic feet per second) }\end{array}$} & \multicolumn{3}{|c|}{$\begin{array}{c}\text { Time } \\
\text { (years) }\end{array}$} \\
\hline & & $\begin{array}{l}\text { Monthly precipitation } \\
\text { (inches) }\end{array}$ & $R^{2}$ & $\begin{array}{l}\text { Standard error } \\
\text { (log units) }\end{array}$ & Span $^{4}$ & $R^{2}$ & $\begin{array}{c}\text { Standard error } \\
\text { (years) }\end{array}$ & Span \\
\hline January & 72 & Oct., Nov., Dec., and Jan. & 0.81 & 0.259 & 0.75 & 0.51 & 28.14 & 0.75 \\
\hline February & 72 & Dec., Jan., and Feb. & .80 & .184 & .60 & .29 & 28.70 & .75 \\
\hline March & 76 & Jan., Feb., and Mar. & .66 & .188 & .75 & .51 & 26.69 & .50 \\
\hline April & 76 & Jan., Feb., and Mar. & .50 & .180 & .75 & .51 & 26.69 & .50 \\
\hline May & 76 & Jan., Feb, and Mar. & .51 & .184 & .75 & .51 & 26.69 & .50 \\
\hline June & 73 & Dec., Jan., Mar., and June & .73 & .344 & .75 & .69 & 30.01 & .50 \\
\hline July & 76 & Jan., May, June, and July & .70 & .430 & .75 & .64 & 27.00 & .60 \\
\hline August & 74 & Feb., July, and Aug. & .64 & .346 & .75 & .39 & 27.35 & .60 \\
\hline September & 79 & May, Aug., and Sept. & .62 & .400 & .75 & .23 & 28.64 & .75 \\
\hline October & 79 & May, Sept., and Oct. & .77 & .339 & .60 & .27 & 30.60 & .60 \\
\hline November & 77 & June, Oct., and Nov. & .74 & .195 & .60 & .26 & 27.30 & .75 \\
\hline December & 76 & Oct., Nov., and Dec. & .78 & .266 & .50 & .38 & 26.76 & .60 \\
\hline
\end{tabular}

${ }^{1}$ Time period for analysis was 1913-2002.

${ }^{2}$ LOWESS regression models:

Response variable, station-adjusted total streamflow: $\log Q_{\mathrm{n}}=\log P_{1}+\log P_{2}+\log P_{\mathrm{n}}$ where $Q_{\mathrm{n}}$ is average streamflow for month n (adjusted for station location), in cubic feet per second, and $P_{\mathrm{n}}$ is precipitation for month $\mathrm{n}$, in inches

Response variable, time: $T_{\mathrm{n}}=\log P_{1}+\log P_{2}+\log P_{\mathrm{n}}$ where $T_{\mathrm{n}}$ is time for month $\mathrm{n}$, in years, and $P_{\mathrm{n}}$ is precipitation for month $\mathrm{n}$, in inches.

${ }^{3}$ Station adjusted total streamflow is the flow adjusted for different station locations. From 1913 to 1926, the flow was multiplied times 0.947 ; from 1928 to 1942, the flow was multiplied times 0.987; and from 1943 to 2002, the flow was not changed.

${ }^{4}$ Span is a parameter that controls the window width and smoothness of the fitted LOWESS model. As the span is increased, the window width is increased and more points influence the magnitude of the fitted values. Thus, a larger span will have a smoother fitted model than a smaller span. 
Table 1H. Results of LOWESS regression analyses between precipitation at Tombstone, Arizona, and station-adjusted maximum daily storm runoff for the San Pedro River at Charleston, Arizona, and between precipitation at Tombstone and time, 1913-2002, for selected months

$\left[R^{2}\right.$, coefficient of multiple determination]

\begin{tabular}{|c|c|c|c|c|c|c|c|c|}
\hline \multirow[b]{4}{*}{ Month } & \multirow[b]{4}{*}{$\begin{array}{c}\text { Number of } \\
\text { years analyzed' }\end{array}$} & \multicolumn{7}{|c|}{ LOWESS regression models ${ }^{2}$} \\
\hline & & \multirow{3}{*}{$\begin{array}{c}\text { Explanatory variables } \\
\begin{array}{c}\text { Monthly precipitation } \\
\text { (inches) }\end{array} \\
\end{array}$} & \multicolumn{6}{|c|}{ Response variable } \\
\hline & & & \multicolumn{3}{|c|}{$\begin{array}{c}\text { Station-adjusted maximum } \\
\text { daily storm runoff }^{3} \\
\text { (cubic feet per second) }\end{array}$} & \multicolumn{3}{|c|}{$\begin{array}{c}\text { Time } \\
\text { (years) }\end{array}$} \\
\hline & & & $R^{2}$ & $\begin{array}{l}\text { Standard error } \\
\text { (log units) }\end{array}$ & Span ${ }^{4}$ & $R^{2}$ & $\begin{array}{c}\text { Standard error } \\
\text { (years) }\end{array}$ & Span $^{4}$ \\
\hline June & 34 & $\mathrm{p}_{0}$ and $\mathrm{p}_{1-10}$ & 0.32 & 0.613 & 0.75 & $\left({ }^{5}\right)$ & $\left({ }^{5}\right)$ & $\left({ }^{5}\right)$ \\
\hline July & 78 & $\mathrm{p}_{0}, \mathrm{p}_{1-10}, \mathrm{p}_{11-30}$, and $\mathrm{p}_{31-60}$ & .64 & .460 & .75 & .62 & 26.77 & .60 \\
\hline August & 78 & $\mathrm{p}_{0}$ and $\mathrm{p}_{1-30}$ & .35 & .438 & .75 & $\left({ }^{5}\right)$ & $\left({ }^{5}\right)$ & $\left({ }^{5}\right)$ \\
\hline September & 71 & $\mathrm{p}_{0}, \mathrm{p}_{1-10}$, and $\mathrm{p}_{11-30}$ & .57 & .548 & .60 & .46 & 29.24 & .50 \\
\hline October & 36 & $\mathrm{p}_{0}$ and $\mathrm{p}_{1-30}$ & .84 & .424 & .50 & .50 & 26.33 & .60 \\
\hline
\end{tabular}

${ }^{1}$ Time period for analysis was 1913-2002.

${ }^{2}$ LOWESS regression models:

Response variable, station-adjusted maximum daily storm runoff: $\log Q_{\mathrm{n}}=\log P_{1}+\log P_{2}+\log P_{\mathrm{m}}$, where $Q$ is maximum daily mean streamflow for month $\mathrm{n}$ (adjusted for station location), in cubic feet per second, and $P_{\mathrm{m}}$ is precipitation for indicated days previous to day of runoff ( $\mathrm{p}_{0}$ is precipitation for day of runoff, $\mathrm{p}_{1-10}$ is cumulative precipitation for days 1 through 10 prior to runoff), in inches.

Response variable, time: $T_{\mathrm{n}}=\log P_{1}+\log P_{2}+\log P_{\mathrm{m}}$, where $T$ is time for month $n$, in years, and $P_{\mathrm{m}}$ is precipitation for indicated days previous to day of runoff, in inches.

${ }^{3}$ Station-adjusted monthly runoff is the runoff adjusted for different station locations. From 1913 to 1926, the runoff was multiplied times 0.947 ; from 1928 to 1942 , the runoff was multipled times 0.987 ; and from 1943 to 2002, the runoff was not changed.

${ }^{4} \mathrm{Span}$ is a parameter that controls the window width and smoothness of the fitted LOWESS model. As the span is increased, the window width is increased and more points influence the magnitude of the fitted values. Thus, a larger span will have a smoother fitted model than a smaller span.

${ }^{5}$ LOWESS regression analysis between time and precipitation was not done because the LOWESS equation between maximum streamflow and precipitation was not sufficiently accurate $\left(R^{2}<0.50\right)$. 
Table 1I. Trends in station-adjusted monthly total streamflow and station-adjusted monthly total streamflow adjusted for variation in precipitation, San Pedro River at Charleston, Arizona, 1913-2002

$[<$, less than; $>$, greater than $]$

Station-adjusted total streamflow (1913-2002) ${ }^{1}$

\begin{tabular}{|c|c|c|c|c|c|c|c|}
\hline \multirow[b]{3}{*}{ Month } & \multirow{3}{*}{$\begin{array}{c}\text { Number of } \\
\text { years analyzed }\end{array}$} & \multicolumn{6}{|c|}{ Kendall tau trend test } \\
\hline & & \multicolumn{2}{|c|}{ Streamflow and time } & \multicolumn{2}{|c|}{$\begin{array}{l}\text { Adjusted streamflow } \\
\text { and time }\end{array}$} & \multicolumn{2}{|c|}{$\begin{array}{c}\text { Adjusted streamflow and } \\
\text { adjusted time }^{3}\end{array}$} \\
\hline & & Slope $^{4}$ & p-value & Slope $^{4}$ & $\mathrm{p}$-value & Slope ${ }^{4}$ & p-value \\
\hline January & 72 & $\mathrm{n}$ & 0.031 & $\mathrm{n}$ & 0.296 & $\mathrm{n}$ & 0.119 \\
\hline February & 72 & $\mathrm{p}$ & .892 & $\mathrm{p}$ & .379 & $\mathrm{p}$ & .131 \\
\hline March & 76 & $\mathrm{p}$ & .872 & $\mathrm{p}$ & .317 & $\mathrm{p}$ & .174 \\
\hline April & 76 & $\mathrm{p}$ & .432 & $\mathrm{p}$ & .459 & $\mathrm{p}$ & .587 \\
\hline May & 76 & $\mathrm{n}$ & .116 & $\mathrm{n}$ & .569 & $\mathrm{n}$ & .224 \\
\hline June & 73 & $\mathrm{n}$ & .001 & $\mathrm{n}$ & $<.001$ & $\mathrm{n}$ & .034 \\
\hline July & 76 & $\mathrm{n}$ & $<.001$ & $\mathrm{n}$ & .008 & $\mathrm{n}$ & .001 \\
\hline August & 74 & $\mathrm{n}$ & $<.001$ & $\mathrm{n}$ & $<.001$ & $\mathrm{n}$ & $<.001$ \\
\hline September & 79 & $\mathrm{n}$ & $<.001$ & $\mathrm{n}$ & $<.001$ & $\mathrm{n}$ & $<.001$ \\
\hline October & 79 & $\mathrm{n}$ & .037 & $\mathrm{n}$ & $<.001$ & $\mathrm{n}$ & .001 \\
\hline November & 77 & $\mathrm{n}$ & .001 & $\mathrm{n}$ & .001 & $\mathrm{n}$ & $<.001$ \\
\hline December & 76 & $\mathrm{n}$ & .031 & $\mathrm{n}$ & .001 & $\mathrm{n}$ & $<.001$ \\
\hline
\end{tabular}

${ }^{1}$ Monthly average streamflow adjusted for different station locations. From 1913 to 1926, the flow was multiplied times 0.947 ; from 1928 to 1942, the flow ws multiplied times 0.987; and from 1943 to 2002, the flow was not changed.

${ }^{2}$ Variation in streamflow that was caused by variation in precipitation was removed by LOWESS regression analysis.

${ }^{3}$ Variations in streamflow and time that were caused by variation in precipitation were removed by LOWESS regression analysis.

${ }^{4}$ Slope of trend: $\mathrm{n}$ is negative and $\mathrm{p}$ is positive.

\begin{tabular}{|c|l|l|}
\cline { 3 - 3 } \multicolumn{2}{c|}{} & p-value \\
\hline $\mathrm{n}$ or $\mathrm{p}$ & no significant trend & $>0.10$ \\
\hline $\mathrm{n}$ & significant negative trend & $<0.05$ \\
\hline
\end{tabular}


Table 1J. Trends in station-adjusted maximum daily storm runoff and station-adjusted maximum daily storm runoff adjusted for variation in precipitation, by month, San Pedro River at Charleston, Arizona, 1913-2002

$[<$, less than; $>$, greater than $]$

\begin{tabular}{|c|c|c|c|c|c|c|c|}
\hline \multirow[b]{4}{*}{ Month } & \multicolumn{7}{|c|}{ Station-adjusted storm runoff (1913-2002) } \\
\hline & \multirow{3}{*}{$\begin{array}{c}\text { Number of } \\
\text { years analyzed }\end{array}$} & \multicolumn{6}{|c|}{ Kendall tau trend test } \\
\hline & & \multicolumn{2}{|c|}{ Runoff and time } & \multicolumn{2}{|c|}{ Adjusted runoff and time ${ }^{2}$} & \multicolumn{2}{|c|}{$\begin{array}{c}\text { Adjusted runoff and } \\
\text { adjusted time }^{3}\end{array}$} \\
\hline & & Slope $^{4}$ & p-value & Slope $^{4}$ & $\mathrm{p}$-value & Slope $^{4}$ & p-value \\
\hline January & 18 & $\mathrm{n}$ & 0.820 & $\left({ }^{6}\right)$ & $\left({ }^{6}\right)$ & $\left({ }^{6}\right)$ & $\left({ }^{6}\right)$ \\
\hline February & 17 & $\mathrm{n}$ & .967 & $\left({ }^{6}\right)$ & $\left({ }^{6}\right)$ & $\left({ }^{6}\right)$ & $\left({ }^{6}\right)$ \\
\hline March & 15 & $\mathrm{p}$ & .018 & $\left({ }^{6}\right)$ & $\left({ }^{6}\right)$ & $\left({ }^{6}\right)$ & $\left({ }^{6}\right)$ \\
\hline April & 7 & $\left({ }^{5}\right)$ & $\left({ }^{5}\right)$ & $\left({ }^{5}\right)$ & $\left({ }^{5}\right)$ & $\left({ }^{5}\right)$ & $\left({ }^{5}\right)$ \\
\hline May & 3 & $\left({ }^{5}\right)$ & $\left({ }^{5}\right)$ & $\left({ }^{5}\right)$ & $\left({ }^{5}\right)$ & $\left({ }^{5}\right)$ & $\left({ }^{5}\right)$ \\
\hline June & 34 & $\mathrm{n}$ & .406 & $\left({ }^{7}\right)$ & $\left({ }^{7}\right)$ & $\left({ }^{7}\right)$ & $\left({ }^{7}\right)$ \\
\hline July & 78 & $\mathrm{n}$ & $<.001$ & $\mathrm{n}$ & .007 & $\mathrm{n}$ & .013 \\
\hline August & 78 & $\mathrm{n}$ & $<.001$ & $\left({ }^{7}\right)$ & $\left({ }^{7}\right)$ & $\left({ }^{7}\right)$ & $\left({ }^{7}\right)$ \\
\hline September & 71 & $\mathrm{n}$ & .002 & $\mathrm{n}$ & .015 & $\mathrm{n}$ & .010 \\
\hline October & 36 & $\mathrm{p}$ & .313 & $\mathrm{n}$ & .361 & $\mathrm{n}$ & .084 \\
\hline November & 17 & $\mathrm{n}$ & .303 & $\left({ }^{6}\right)$ & $\left({ }^{6}\right)$ & $\left({ }^{6}\right)$ & $\left({ }^{6}\right)$ \\
\hline December & 19 & $\mathrm{p}$ & .624 & $\left({ }^{6}\right)$ & $\left({ }^{6}\right)$ & $\left({ }^{6}\right)$ & $\left({ }^{6}\right)$ \\
\hline
\end{tabular}

${ }^{1}$ Maximum daily mean streamflow for month adjusted for different station locations. From 1913 to 1926, the flow was multiplied times 0.947 ; from 1928 to 1942, the flow was multiplied times 0.987; and from 1943 to 2002, the flow was not changed.

${ }^{2}$ Variation in runoff that was caused by variation in precipitation was removed by LOWESS regression analysis.

${ }^{3}$ Variations in runoff and time that were caused by variation in precipitation were removed by LOWESS regression analysis.

${ }^{4}$ Slope of trend: $\mathrm{n}$ is negative and $\mathrm{p}$ is positive.

${ }^{5}$ Sufficient data were not available to perform trend analysis.

${ }^{6}$ Sufficient data were not available to perform LOWESS regression analysis and to create adjusted values of runoff and time.

${ }^{7}$ LOWESS regression equations for June and August runoff were not accurate enough to use for adjusted values of runoff and time.

\begin{tabular}{|c|l|l|}
\cline { 3 - 3 } \multicolumn{2}{c|}{} & p-value \\
\hline $\mathrm{n}$ or $\mathrm{p}$ & no significant trend & $>0.10$ \\
\hline $\mathrm{n}$ & nearly significant negative trend & $0.05-0.10$ \\
\hline $\mathrm{n}$ & significant negative trend & $<0.05$ \\
\hline $\mathrm{p}$ & significant positive trend & $<0.05$ \\
\hline
\end{tabular}




\section{Appendix 2}

\section{Supplemental Data for Analysis of Step Trends in Streamflow}

Table 2A. Results of least-squares regression analyses between precipitation at Tombstone, Arizona, and monthly total streamflow for the San Pedro River at Charleston, Arizona, for selected time periods

$\left[R^{2}\right.$, coefficient of determination; ---, no data; <, less than; >, greater than $]$

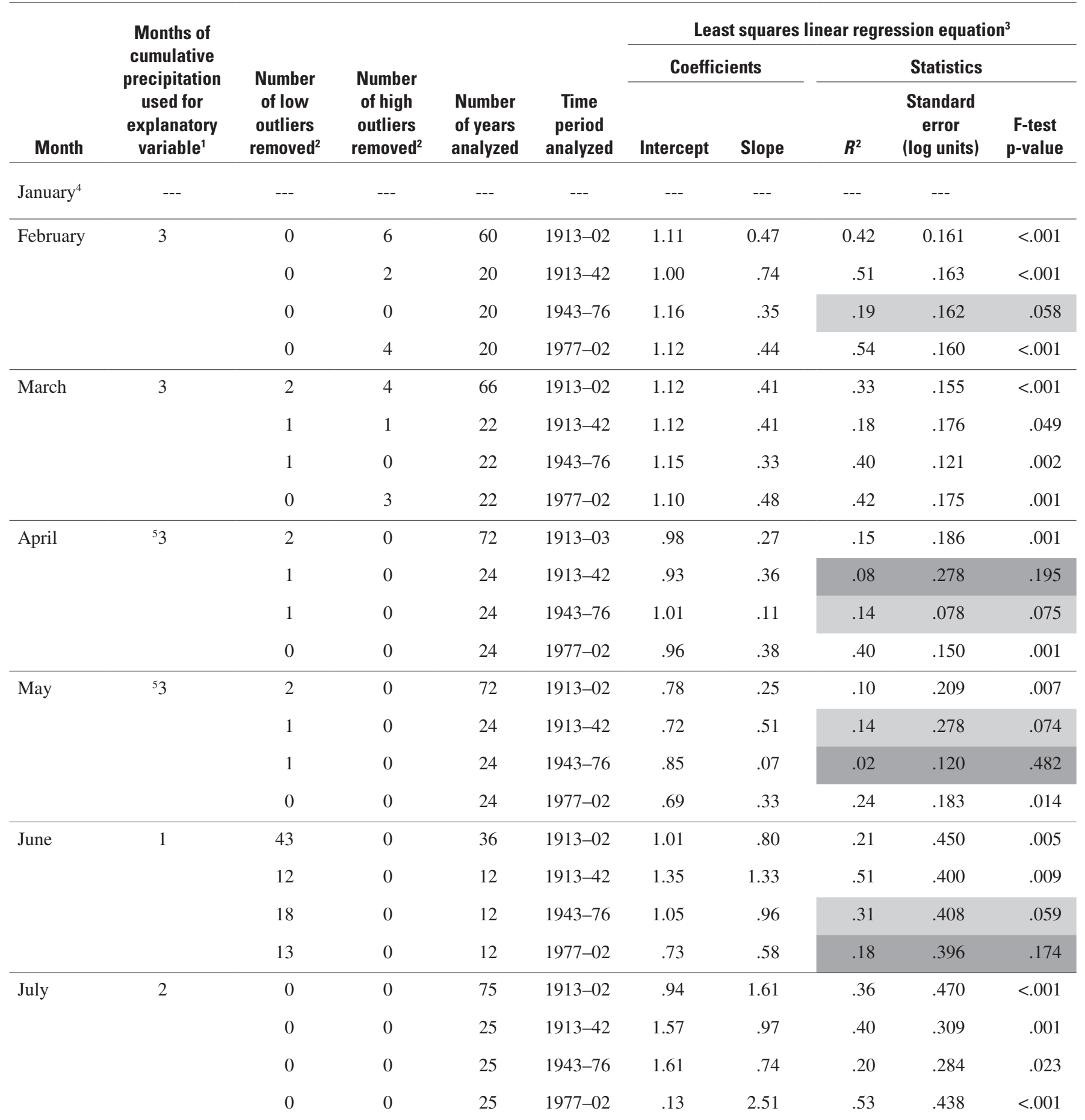


Table 2A. Results of least-squares regression analyses between precipitation at Tombstone, Arizona, and monthly total streamflow for the San Pedro River at Charleston, Arizona, for selected time periods-Continued

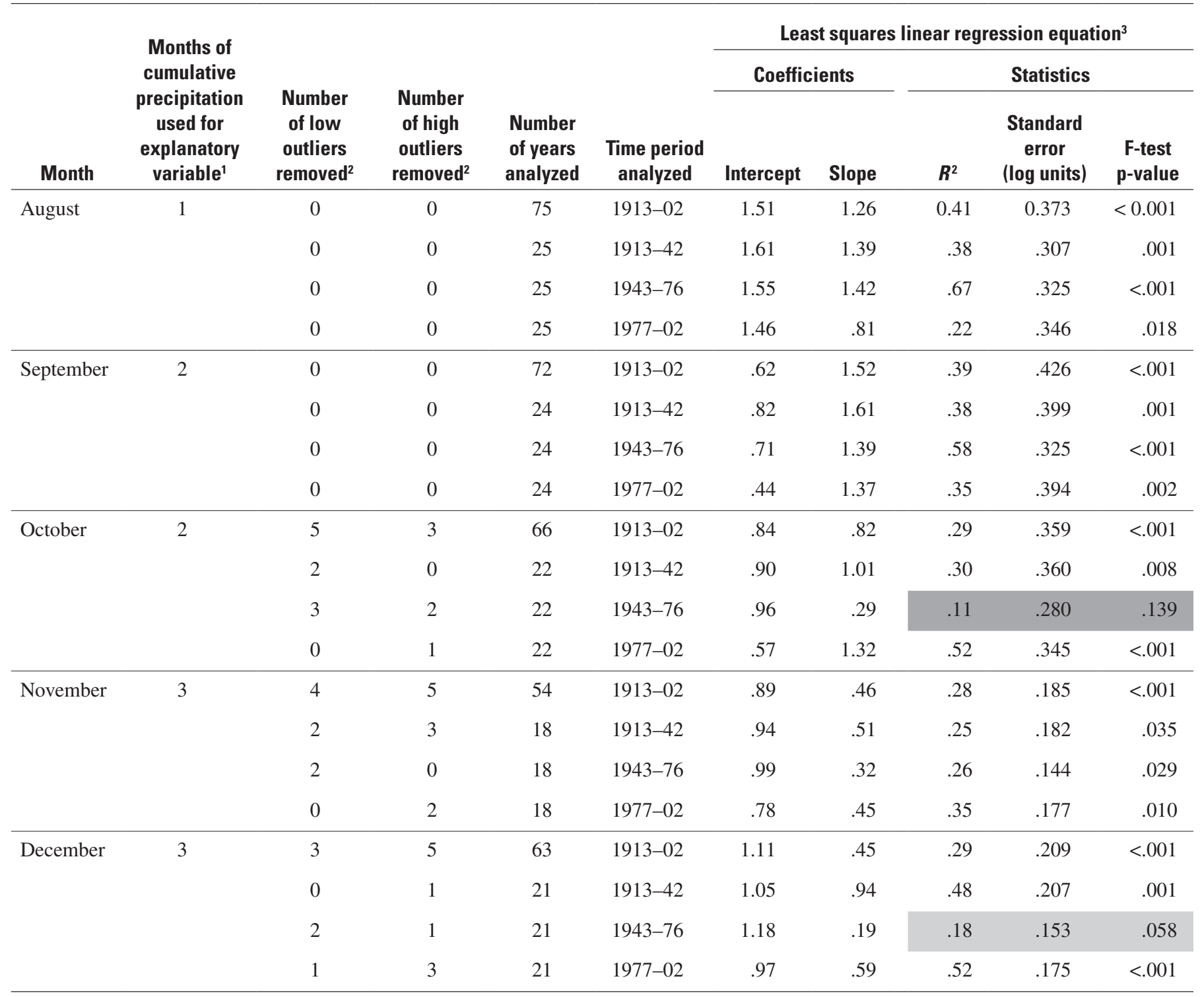

${ }^{1}$ Precipitation for same month as streamflow and indicated number of previous months ( 1 is precipitation for same month, and 2 is precipitation for same month and one previous month).

${ }^{2}$ See page 31 for explanation of outliers

${ }^{3}$ Regression equation is $\log Q=B_{1}+B_{2} \log P$,

where

$$
\begin{aligned}
& Q=\text { monthly average streamflow }, \text { in cubic feet per second; } \\
& P=\text { cumulative precipitation for indicated months, in inches; } \\
& B_{1}=\text { regression intercept } \text { and } \\
& B_{2}=\text { regression slope. }
\end{aligned}
$$

${ }^{4}$ Linear regression equations could not be adequately fit to data.

${ }^{5}$ Months of cumulative precipitation are January, February, and March.

\begin{tabular}{|l|l|l|}
\cline { 3 - 3 } \multicolumn{2}{l|}{} & $\mathrm{p}$-value \\
\hline & no significant regression equation & $>0.10$ \\
\hline & nearly significant regression equation & $0.05-0.10$ \\
\hline & significant regression equation & $<0.05$ \\
\hline
\end{tabular}


Table 2B. Results of least-squares regression analyses between precipitation at Tombstone, Arizona, and maximum daily storm runoff for the San Pedro River at Charleston, Arizona, for selected time periods

$\left[R^{2}\right.$, coefficient of determination; $<$, less than $]$

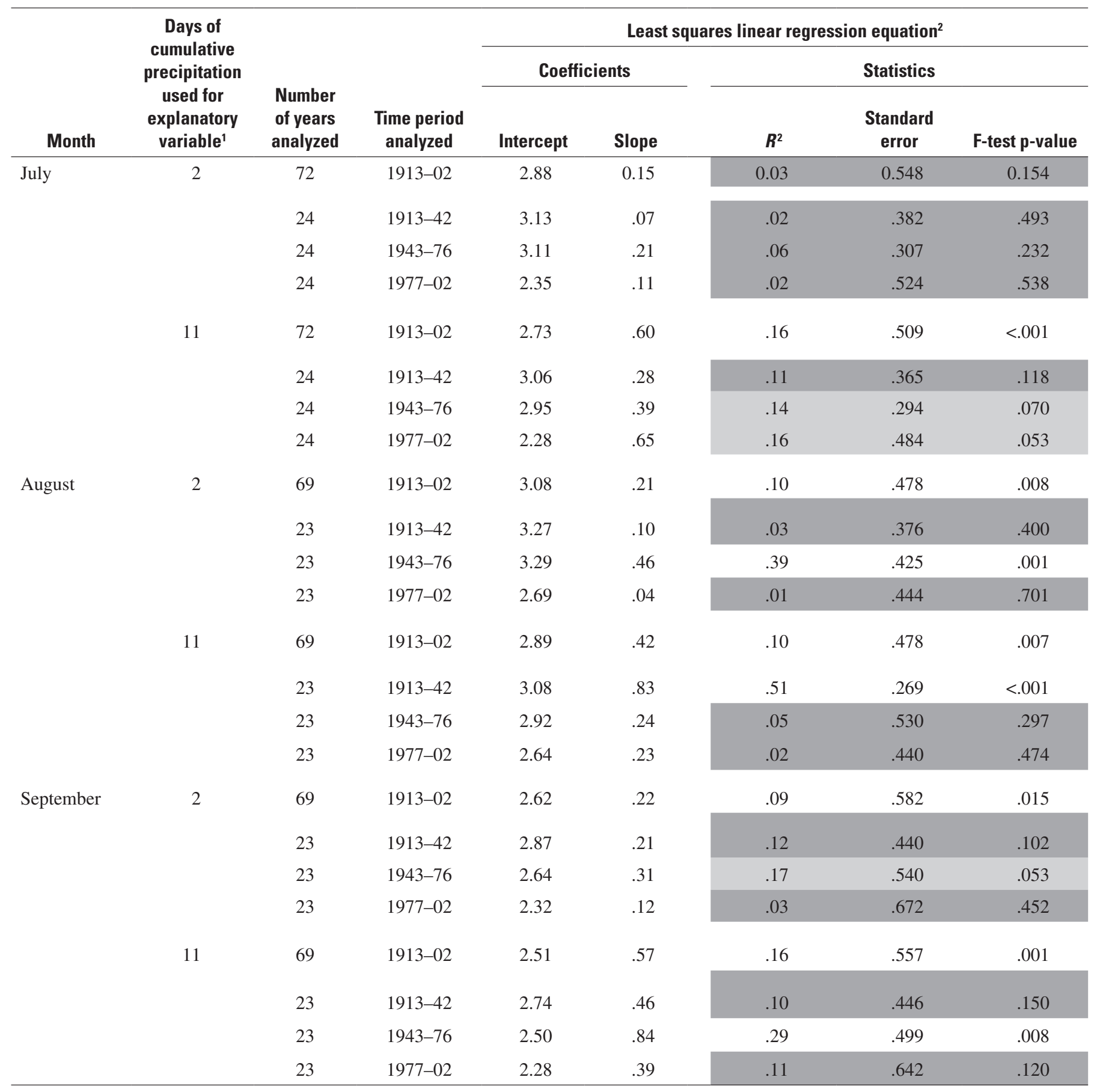

${ }^{1}$ Precipitation for same day as daily runoff and indicated number of previous days ( 2 is same day and 1 previous day, and 11 is same day and 10 previous days).

${ }^{2}$ Regression equation is $\log Q=B_{1}+B_{2} \log P$,

where

$Q=$ monthly maximum daily mean streamflow, in cubic feet per second;

$P=$ cumulative precipitation for indicated days, in inches;

$B_{1}=$ regression intercept; and

$B_{2}=$ regression slope.

\begin{tabular}{|l|l|l|}
\cline { 3 - 3 } \multicolumn{2}{l|}{} & p-value \\
\hline & no significant regression equation & $>0.10$ \\
\hline & nearly significant regression equation & $0.05-0.10$ \\
\hline & significant regression equation & $<0.05$ \\
\hline
\end{tabular}


Manuscript approved for publication, May 09, 2005.

Prepared by the Reports Section, U.S. Geological Survey, Tucson, Arizona.

USGS Publishing staff

Steve A. Longsworth, Supervisory Hydrologist

Tracey L. Suzuki, Technical Editor

John Callahan, Illustrator

For more information concerning the research in this report, contact the Arizona Water Science Center Director,

U.S. Geological Survey, 520 N. Park Ave., Suite 221

Tucson, AZ 85719

http://az.water.usgs.gov 
Inside Back Cover Blank 


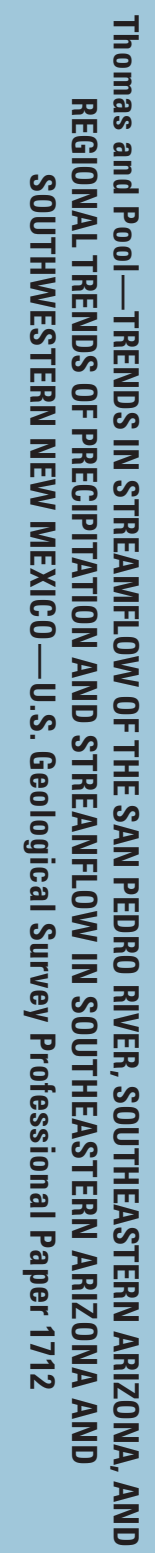

ISBN $1-41]-30668-6$

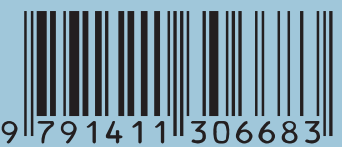

8 Printed on recycled paper

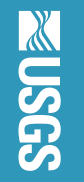

